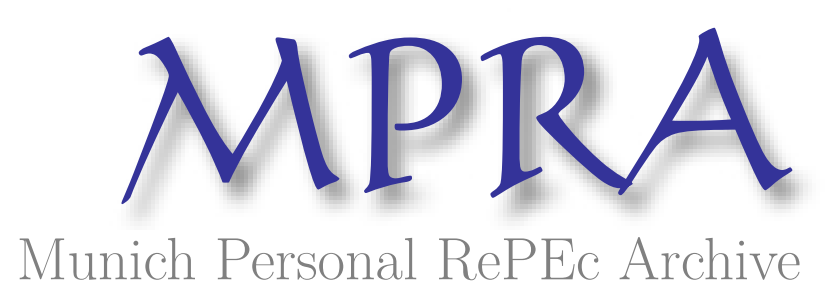

\title{
Nigerian economy: business, governance and investment in period of crisis
}

Ibrahim Abdullahi, Shafiu

23 October 2018

Online at https://mpra.ub.uni-muenchen.de/91074/

MPRA Paper No. 91074, posted 31 Dec 2018 10:41 UTC 


\section{NIGERIAN ECONOMY BUSINESS, GOVERNANCE AND INVESTMENT IN PERIOD OF CRISIS}

SHAFIU IBRAHIM ABDULLAHI 
Copyright @ 2018 ECONOMIC ISSUES, P.O. BOX 14608 KANO-NIGERIA

Text copyright @ 2018 Shafiu Ibrahim Abdullahi

All rights reserved. No part of this material may be reproduced, stored in a retrieval system, or transmitted, in any form or by any means for a commercial purpose, without the prior permission of the author. 


\section{Contents}

\section{Preface}

II. Introduction

III. Inflation, growth and macro-management

1- Nigeria economic conundrum

2- Economic growth and human development

3- Inflation and public debt

IV. Money, banking and finance

1- Central Banking

2- Commercial banking

3- Banking reform

4- Conventional and Islamic banks

5- Microfinance

v. Capital market and foreign investment

1- Nigerian stock exchange

2- Capital market supervision

3- Effect of government policy on capital market

4- Foreign investments

VI. Trade and Business management

1- Retail Business

2- Brand Building

3- Business Conglomerates

4- Entrepreneurship

5- Real Estate Business

VII. Corruption, insecurity and climate change

1- Corruption and development

2- Regional development

3- Effect of insecurity on development

4- Climate change and development

VIII. Women in government and business

1- Role of Women in Development

2- Women and corruption

3- Women and Entrepreneurship

IX. Economics education, media and technology

1- Economics of education

2- Financial journalism

3- Advertising in Nigeria 
4- Technology Startups

X. Islamic banking and finance

1- Nature of Islamic Banking

2- Islamic banking: a brief history

3- What next for Islamic finance?

4- Islamic stock index

5- Islamic businesses

6- Contributors to development of Islamic economics, banking and finance

7- Islamic economics and finance in Nigerian universities

8- Media and Islamic banking

XI. Nigeria and the rest of the world

1- World Trade

2- Economy and Trade in Africa

3- Economic blocs

4- Trade politics

XII. Bibliography 


\begin{abstract}
About the author
Shafiu Ibrahim Abdullahi works as university lecturer in Nigeria. He has previously worked in media and banking industries in Nigeria. He has published papers in Journals such as International Journal of Ethics and Systems (Emerald), Journal of Islamic Marketing (Emerald), Middle East Journal of Management (Inderscience), International Journal of Islamic Marketing and Branding, (Inderscience), and Journal of Advanced Studies in Finance, among others. His works also appeared in Newspapers and as book chapters. He has also reviewed for Journal of Islamic Marketing, International Journal of Islamic Marketing and Branding, and International Journal of Islamic and Middle Eastern Finance and Management. Email: shafiuibrahim@gmail.com
\end{abstract}




\section{Preface}

This book has its origin in my writings in newspapers and my (rested) online blog 'Economic Issues'. The popularity of my online writings made me to rethink about converting these wide and diverse contributions into a book for the benefit of larger audience, research and documentation. My previous writings have covered wide areas from inflation, unemployment, poverty, retail business, media to Islamic finance. The content of this book has more richness and depth than what was content in the original individual pieces from which the book was formed. About 35\% of the book contents new researches added to the book in order to enrich the book and make it up to date with the very recent happenings in Nigeria and around the world. The book brings together my political, economic and financial writings and researches of roughly the last one decade. I was inspired by classical economics works such as collected works of Paul Samuelson, though this book contents works that target both academic and nonacademic audience. The manner in which the book was written and compiled made it easy for comprehension of people not familiar with technical economic jargons and happenings in Nigeria. As a matter of fact, the book is not a technical economic textbook, it is a diary of economic and business events that happened in Nigeria in the pass one decade. The book is suitable for international investors, businessmen, researchers, journalists and policy makers who want to know more about Nigerian economy. But, the broadness and relevance of these issues also made it suitable for students and teachers looking for up-to-date book on Nigerian economy. Beside the journalistic contents, the book was (in some places) supplemented by normal text book introductions and definition of central ideas discussed in the book. The randomness in the ideas discussed by the book is because of the fact that the individual chapters were written over a period of time according to event taking place in Nigeria between 2008-2018. Hence, the book in itself serves as important historical diary of the events in Nigerian economic life during the last decade. The events in this book have been updated from the period they were first published on my blog and as opinion pieces in newspapers, in order to reflect current developments and economic position of Nigeria. Nigerian economy has not been discussed thoroughly in mediums such as books that layman can understand devoid of technical jargons of academic economics. Nigerian academics are preoccupied with writing technical journal papers that will get them professorship. On the other hand, Nigerian journalists who cover finance and economics in most cases lack the economic background to write work of this nature. The available books in the 
market were written over thirty years ago, providing the need for new books that take care of recent events in the Nigerian economy. Boko Haram insurgency that dominated most of the news coverage on Nigeria during the period has monumentally affected the economic and financial events reported in this book. Thus, this book is more less an account of economic events during Boko Haram uprising in Nigeria.

\section{Shafiu Ibrahim Abdullahi}

shafiuibrahim@gmail.com

Kano-Nigeria

October, 2018 


\section{INTRODUCTION}

Let begins with some macroeconomic statistics; recently, Nigerian economy was ranked number one in Africa with real GDP of about $\$ 568.5$ billion in 2014, $\$ 481.1$ billion in 2015, $\$ 405$ billion in 2016 and $\$ 376.3$ billion in 2017. Its GDP in term of purchasing power parity (PPP) was ranked $25^{\text {th }}$ in the world with $\$ 1.119$ trillion in 2017. But, the figure is lower than the $\$ 1.137$ trillion obtained in 2016. It was ranked as lower middle income nation with per capita GDP in term of PPP of $\$ 5,900$ in 2017. Nigeria's major export commodity is crude oil accounting for about $95 \%$ of its total export. Nigeria total import in 2017 stood at $\$ 35.24$ billion while inflation stood at $16.5 \%$, and unemployment at $13.4 \%$. Government economic measures, depreciation in the value of Naira and decline in oil revenue have combined to force Nigerians into cutting down on consumption of imported goods and services. The official exchange rate of Naira to Dollar in 2017 stood at 323.5 Naira, this shows lack of improvement in the value of Naira against the US Dollars. In 2001, Nigeria GDP was estimated at $\$ 40.9$ billion, but a decade and half later it jumped to $\$ 376.3$ by 2017 . In order to demonstrate more clearly Nigeria socioeconomic position in Africa, I have compared its macroeconomic figures with South Africa's. Comparing Nigeria with its nearest African rival, South Africa's GDP in 2001 was $\$ 113.3$ billion and in 2017 it was $\$ 349.3$ billion. Looking at these figures one might wonder on the manner Nigerian economy, that was about one third the size of South Africa's in 2001, came to become the biggest economy on the continent less than fifteen years later. Reason number one being, during the period Nigerian economy has grown at higher rate than South Africa's. Two, in 2014 Nigeria had rebased her economy annual GDP (using newer estimation procedure) from the previously used base year of 1990; that instantly made her economy to become number one in Africa. In 2004, inflation rate in Nigeria hovered around $17-18 \%$ while South Africa had inflation rate of about $0.2 \%$. In 2017, Nigeria has inflation rate of $16.5 \%$ and South Africa has 5.3\%. These figures show that South Africa is still doing better than Nigeria in managing inflation. Recently, both Nigeria and South Africa have found themselves in recession. Nigeria officially entered recession in 2016 while South Africa in 2018. Despite both countries finding themselves in recession recently, people living below poverty level in Nigeria comprises about $65 \%$ of the population, while in South Africa it is $17 \%$ that live below poverty limit.

In 2004, Nigerian foreign reserve stood at $\$ 7$ billion, by 2018 it has jumped to $\$ 47$ billion, though there was a lot of fluctuations along the way. South Africa reserve in 2018 is $\$ 49$ billion. While in 2001, Nigeria export of goods stood at $\$ 1.8$ billion and South Africa's $\$ \$ 30.6$ billion. But, 
in 2017 Nigeria's export stood at $\$ 40.81$ billion and South Africa's $\$ 78.2$ billion, showing higher percentage increased in Nigeria than South Africa. In term of population, in 2017 Nigerian population stood at 190.63 million and South Africa's 56.52 million. Thus, Nigeria has more than three times the population of South Africa. Nigerian economy will double that of South Africa in the near future, taking these indicators into consideration. But, its GDP per capita will still be lower than South Africa's due to the huge size of Nigerian population, expected to become the third most populous country in the world around 2050. Nigerian government budget for 2017 stood at $\$ 22.15$ billion, but that of South Africa stood at $\$ 103.3$ billion, more than four times that of Nigeria. This clearly demonstrated the level of underdevelopment of Nigeria when compared to South Africa. But, public debt in Nigeria is lower than in South Africa, with figures of $23.4 \%$ and $52.7 \%$ in 2017 respectively. In the same year, interest rate on commercial bank lending in Nigeria stood at $17.5 \%$ while South Africa's is $10.4 \%$, this also tells a lot about the scarcity of capital in Nigeria when compared to South Africa. For stock of domestic credit which is an important economic indicator, in 2017 Nigeria's stood at $\$ 79.26$ billion while South Africa's stood at $\$ 237.6$ billion, about three times the value of Nigeria's. When it comes to the other important source of capital that is equity, market value of publicly traded shares for Nigeria in 2016 was just \$53 billion; but, South Africa's stood at $\$ 735.9$ billion, more than thirteen times that of Nigeria. In term of attraction of foreign direct investment (FDI) in 2017, Nigeria is doing fairly good when compared to South Africa; Nigeria FDI stood at $\$ 118$ billion and South Africa stood at $\$ 139.2$ billion. Despite this, South Africa is still far ahead of Nigeria in term FDI abroad, Nigeria could only manage \$17 billion in 2017, when South Africa invested a whopping \$176.3 billion abroad in the same year. But, inequality is higher in South Africa than Nigeria with Gini coefficients of 62.5 and 48.8 respectively in 2013 . This might be as a result of past historical injustice, due to apartheid policies. Unlike Nigeria that employed about $70 \%$ of her labour force in agriculture, South Africa only employed about $4.6 \%$.

Nigerian economy is very sensitive to happenings in the global crude oil market due to Nigeria dependence on the black gold. The recession Nigeria found herself in 2016 was mainly caused by the fall in the international price of crude oil. It is the same factor that also help to explain Buhari government massive borrowings to help close the gap in government budget since coming to power in 2015. Empirical and theoretical evidences have linked shocks in price of primary products with macroeconomic imbalances. These external shocks are main sources of economic volatility, affecting both private and public savings, in part because of their large income effects (Agenor and Azenman, 2003). But during oil boom, the high price of oil has positive effects on the economy of the oil exporting nations. Between 2010 to 2013, Nigerian government had received trillions of Naira from the oil revenue, helping to finance Jonathan federal government and state governors run away expenditures. Nigerian banking industry like most areas of the economy heavily dependent on revenue from the oil sector to maintain liquidity and balance their books. Hence, the reason why previous banking crisis in Nigeria coincided with fall in the price of crude oil in the international market. In the past one decade, the global economy has been enmeshed in how to recover from the global financial crisis of 2008. 
At the peak of the crisis, investors were sceptic of investing in the developed financial markets because of the fear of contagion from the crisis. As a result, the attraction of emerging markets to Western investors increased. Nigerian stock exchange was one of the victims of the crisis. The All Share Index of the Nigerian stock exchange collapsed to its all-time low. Ten years after, the market is yet to recover to its pre-crisis level. In the period since the global financial crisis, Nigerian economy has entered recession twice and the value of its currency depreciated. This only confirm the fact that Nigerian economic problem is complex and multi-dimensional, requiring a much broader approach.

Efforts to diversify Nigerian economy have been on the Nigerian government agenda since 1980s, but not much has been achieved. Despite the billions of Dollars in oil revenue, Nigerian governments have failed to use the resources to develop other areas of the economy. The liberalization of the economy by Obasanjo and Jonathan governments has not achieved the desire effects, instead resulting in more unemployment, poverty and made Nigerian economy more import depended. Since coming to power in 2015, President Buhari has tried to reverse some of the previous governments policies hoping to diversify Nigerian economy in the process. He spearheaded government policy that provided subsidies and incentives to selected sectors of the economy. Major beneficiaries of this policy are agriculture and manufacturing. His government has been trying to revive the old import substitution firms established in Nigeria during the 1970s and 1980s. This he hopes will help reduce Nigeria dependence on importation from abroad. The Nigerian agricultural sector has received special attention following the commitment of the Buhari administration to turn the sector around and stop importations of agricultural products. The figures released by National Bureau of Statistics (NBS) and Central Bank of Nigeria (CBN) supported the government claimed of huge reduction in importation of rice a fall of about $90 \%$ from the importation figure of 2015 . The exportation of agricultural output has also increased between 2015-2018. Agricultural sector provided about $21.6 \%$ of Nigeria GDP and the largest share of Nigerian laborers (70\%) work in the sector more than any other sector of Nigerian economy. Nigerian agriculture still suffered from the problems of used of old farming implements, low level of technology, low level of literacy characteristic of most Nigerian farmers, poor financing (government and banks inability to make credit available to poor farmers), subsistent nature of Nigerian agriculture and the slow take off of commercial agriculture. The Nigerian agricultural sector consists of a mix of modern mechanized production and the traditional low technology techniques. Studies have found finance in agriculture to be critical and as important for improved productivity, as technical input can only be purchased and used by farmers if they have required fund at their disposal (Mbutor, Ochu and Okafor, 2013).

Nigeria has also been in the centre of migration crisis that has given European leaders sleepless nights. Thousands of Nigeria were involved in this great migration of Africans to Europe, taking advantage of the crisis in North Africa to sneak into the European Union countries. Like other African countries, the main reason for Nigerians in migrating to Europe is mainly to look for greener pasture away from poverty and unemployment that most Nigerian youth have found themselves. Africa has been on the receiving end of perennial wars, fall in the price of natural 
and agricultural resources, and poor leadership. The political revolution in North Africa in 2011 has not only made it easier for African migrants to reach Europe, but has contributed to strengthening of Boko Haram insurgency in Nigeria through the spread of arms from Libya to Nigeria. Recently, European leaders from Angela Michel of Germany, Theresa May of UK to Emmanuel Macron of France have visited Abuja Nigerian capital to discuss ranging issues from trade, security to migration. Theresa May was motivated by the need to make adequate preparation ahead of UK exit from the European Union in 2019. UK is looking back strategizing on how to strengthen its old relationship with its former colonies in Africa. Germany and France were looking for ways to increase trade ties with Nigeria in view of the increasing inroad China is making into Africa. European leaders have begun to see things from the others perspective, that it is in their best interest to help African countries to deal with the economic and humanitarian crises facing the continent. In the last one decade, China has become the largest investors in Africa. The value of its trade with Africa has surpassed that of any other nation in the world. China has loaned billions of Dollars to Africa through investment in infrastructures; though lately there were fears expressed by stakeholders of another debt trap involving African nations in the near future. As a sign of increase cordial relation with African countries, China and Africa hold frequent international forums to discuss further trade relationships. But, countries from the US, Canada to European Union nations have warned Africa to be worry of Chinese loan diplomacy.

In the years since independence, Nigerian economy has changed from its largely agrarian state of 1960 s to an import depended mono-economy. Nigeria single most important export for more than forty years has remain crude oil. But, in the period since independence various economic models have been tested, as many as there were changes in governments. While the adaptation of some of these economic programs were domestically inspired, others were forced on Nigeria from the outside. A good example of an externally inspired economic model, is structural adjustment program (SAP) of Ibrahim Babangida military regime. Nigeria has experimented with economic models that include, largely raw materials exporting mixed economy, import substitution industrialisation, structural adjustment program, guided deregulation, export promotion to privatisation and liberalization of the economy. Briefly after taking power in 2015, president Buhari has tried to reverse government economic policy and adopt some of the economic policy he used when he was military head of state in 1984-1985. In the 1960s and 1970s, Nigeria followed the same industrial policies adopted by South Korea, Malaysia and Brazil, but forty years after, these nations have made economic progresses while Nigeria is left stagnant, adding little to its 1970s economic status when Nigeria depended on the export of her newly found wealth: crude oil. Though, Nigerian population has increased more than four times since that period. In between the periods, Nigeria became very important exporter of crude oil in the international markets. Many scholarly contributions have proposed connections between state of Nigerian economy and the so called Dutch diseases. According to Dutch dieses hypothesis, reliance on natural resources (or any other single source of foreign exchange) has the tendency to make an entire economy lazy, turned mono-economy, ill motivated and becoming too dependent on that single sources of foreign exchange without 
making efforts to find alternative sources of revenue. Dependence on primary product is very problematic, as Nigeria has seen over the years, due to the unpredictability in the price of crude oil. Between 1999 to 2017 Nigeria has generated over $\$ 900$ billion from sale of crude oil in the international market. But, despite this huge amount of money the lot of Nigerians did not change for the better.

Nigerian political history was uneven, with history of military coups that toppled democratic government after democratic government. Thus, like most other African countries, Nigeria history after independence from Britain was dominated by military rule. The military had shaped Nigeria in these years and still do, whether in the role they are playing to restore peace and security in different parts of Nigeria or in the number of retired military personal that are still active in politics. The civil war that Nigeria found herself in, just seven years after independence, still hunts Nigerian leadership with fear of another cessation attempt. The Igbo who led the breakaway republic of Biafra during the civil war still found it difficult to convince other Nigerians that they really care about the unity of Nigeria. As a result, the Igbo have at various time complaint of discrimination, of being treated as second class citizens in their own country. It is estimated that Nigeria has over 350 ethnic groups, one of the few countries in the world with that large number of people who speak different languages; though, there are three major ethnic groups, Igbo in the south east, Hausa in the north and Yoruba in the south west. Since return to civilian rule in 1999, there was unwritten agreement for power to be shared between the northern part of the country and southern part of the country. That agreement could not be said to have been adhered to strictly looking at the events of the past years. In a rare political occurrence in Africa political history, Nigeria successfully achieved transition from a ruling political party to an opposition party in 2015. During the general election of 2015, former ruling party president (Goodluck Jonathan) accepted defeat and handed over power to the newly elected President Muhammed Buhari. The event was hail all over the world, as an exemplary in African politics. The current experimentation with democracy is the longest in the history of Nigeria, that has not been interrupted by military coups. Nigeria's first republic had lasted for only six years; subsequent republics were not that lucky. Looking back, in the nearly 60 years of Nigeria's independence, the period in which civilians ruled Nigeria was economically better off for Nigerians that when military generals were in charge.

But, a deadly uprising that threaten the civilian rule (from 1999 to date) was dangerously germinating since around the time civilian government of Obasanjo came to power in 1999. But, the government in power did not pay much attention to it, looking at it as small event that would come to pass. History has proved them wrong, Boko Haram insurgencies founded in North East part of Nigeria went on to threaten the peace and stability of Nigeria. The failure of the then ruling party to win election in 2015 is widely seen as the result of its failure to defeat Boko Haram. Boko Haram uprising led to the killing of over twenty thousand lives and destruction of properties worth billions of Naira. The damage caused by the uprising is far much higher than it was earlier assumed, as it could not be quantified entirely by government or any other body. Before the height of the event, Nigerian economy was doing well, looking very promising to surpass the 
expectations of forecasters who saw Nigeria as entering the league of big economies in the world. But, as a result of the Boko Haram event most of these forecasts were reversed. The entire northern part of Nigeria was devastated by the Boko Haram phenomenon, leading to greater socio-religious consequence. Neighbouring countries such as Niger, Chad and Cameroon were also hurt by the uprising as they also loss lives and properties. These countries, like in Nigeria, were overwhelmed by the number of refugees they have to take care of. Boko Haram insurgency has its roots in government neglect of the education sector, poverty, youth unemployment, and poor governance at all level of government. Corruption a lone has led to the sustenance of the insurgency, as money meant for fighting the insurgent were stolen by top government officials both in the military, political class and civil service. The geographical reach of the Boko Haram that was initially restricted to the North east later spread to the whole north including Abuja, from there insurgents had started threatening Lagos, Nigeria commercial capital, before they were later forced back to their original place of birth around lake Chad in Borno state. For this reason, no any account on Nigerian economy in the last ten years will do justice to the topic without involving the Boko Haram incidence.

This book particularly looks at the condition Nigeria found herself at the height of Boko Haram insurgency in the northern part of the country. Here the book provides firsthand account of the state of Nigerian economy and that of the North as a result of the crisis. It narrated the socioeconomic causes of the insurgency and proffer solutions. The period of the events covered by this book range from 2008-2018. Additional materials from my blog articles were edited and updated in line with recent developments. This book is relevant for international investors eyeing the Nigerian market. The book covered almost all the main sectors of the Nigerian economy. The book is encyclopedic in term of coverage of Nigerian business environment and potential threats to ease of doing business. The structure of the book makes it easy for readers to browse through it. Its chapters are grouped according to related themes in the Nigerian economy. The bibliography section provided at the end of the book provide the reader with range of sources for reference and further research. 


\section{INFLATION, GROWTH AND MACRO-MANAGEMENT}

\section{$\underline{\text { Nigeria economic conundrum }}$}

It was Lord Maynard Keynes that popularized the adage, in the long run we are all dead! The adage was coined on the backdrop of great depression of 1930s when major world economies went into depression, a far worst economic phenomenon than a recession. It took the general adaptation of what is today known as Keynesian economic thought to get the developed countries of the world out of the great depression. Recently, Nigeria had to use resources on smaller scale to get out of recession it found herself in 2016. The Keynesian school of economic thought believed that an economy needs government interventions to get out of recession, while the classical school of thought believed an economy is capable of self-regulation. The government interference Keynesians were talking about is in term of fiscal policy instruments such as tax reduction and increase in government expenditures to increase availability of money in the economy. Thus, an economy like that of Nigeria that was in recession in 2016 needed an expansionary fiscal policy to get the economy out of the sluggish growth caused by recession. This brought us to the question of whether Nigeria needed measures such as Treasury Single Account (TSA) at moment of crisis when government needed to pump cash into the economy? Though, most of the Nigerian bankers opposed TSA, other Nigerians supported it. Central Bank on its part needed to pump more money into the economy for the same reason of need to increase liquidity in the economy. This is the stand of monetarist who called for use of expansionary monetary policies to get out of recession. To achieve macroeconomic stability in any economy there is always an interplay between fiscal and monetary policy; that is why it was wrong to put too much blame on Nigerian Central Bank who controlled monetary policy at the expense of the executive arm of the government that controlled fiscal policy. Central Bank alone through changes in interest rate and foreign exchange controls could not pull the economy out of recession. Federal government had to come-in through expansionary fiscal policy. This was the reason why many analysts saw the delay in signing budget as very dangerous for an economy that needed quick attention. Both the executive and legislative arms of the government were playing with fire that would come back to burn them which Nigerians later witnessed. The shape of Nigerian recession of 2016, as it later become clear, is V shape described as short. It lasted for two quarters. 
Sometimes, when you take critical look at President Buhari economic policies, you notice policy inconsistencies. Imaging introducing new types of tax such as the communication tax when a sick Nigerian economy was down in recession in 2016, badly needing blood through injection of money into the economy to revive critical sectors of the economy. What government should have done was to release more money into the economy and not to squeeze things. This have been the worst recession to hit Nigeria since 1987, according to data from IMF the economy experienced negative growth for two consecutive quarters of 2016. At the time, a national leader of the ruling All Progressive Party had called for "economic restrategising and re-planning". At the then level of foreign exchange rate deterioration, Nigerian economy would lose a lot if it continued with importation of all kind of things. According to the minister of agriculture Audu Ogbe, Nigerian importers required the sum of $\$ 2.5$ billion every week in order to pay for imports. Now consider a situation when there was no source of getting the billions dollars used in paying for the import? This justify the need for domestic production of goods and the liberalisation of Naira in order to make export cheaper. The later move toward diversification of the economy was a good move. It would take the economy out of the grip of the oil sector and make it dynamic. Thus, the revival of agriculture embark upon by government is good. But, what was done was not enough. You could not revive agriculture by just closing your border and banning imports, it is not a mere mechanical thing. It is more than that. Government needed to carry everyone on board, whether you were in PDP, APC, poor, rich, living in Nigeria or in diaspora. As government moved towards diversification of the economy, federal government must equally find a lasting solution to the militancy in the Niger Delta. Oil was still the major earner for Nigerian government, anything that affected it would touch government revenue and it ability to execute projects.

Buhari government move to borrow from international creditors was not bad as it looked, if done in the most efficient manner. The interests on the debt should be manageable not something that would return Nigeria to the era of debt overhangs of the 1980s and 1990s. But, the borrowed money had helped bridge the gap left by falling oil revenue and injected most needed liquidity into the economy. Increased government spending on power projects, railways, roads, construction of dams, housing projects, and agriculture helped revive the economy in the medium to long term. Released NBS statistics on the economy showed that agriculture and service sectors were the major movers of the economy. A top IMF official Mitsuhiro Furusawa in an interview observed that there appeared to be a conflict between inflation and economic growth in Nigeria. He called for Nigerian authorities to go for price stability as they strived to achieved economic growth. He also called for more independence for Central banks in matters related to monetary and foreign exchange policies, which has been the unanimous opinion of top economist around the world for about two decades now. Political interference of any kind in economic policies was at the heart of Nigeria economic problems, so were other big economies such as Russia, Brazil, South Africa, and Egypt. The earlier politicians learn to appoint competent people and allow them to do their work the better. Too much interference is bad for economic progress. Among measures taken by the government to diversify the economy were attraction 
of foreign investors in solid minerals, telecommunication and agriculture by giving tax holidays and import waivers. Nobody is just condemning Buhari initial adaptation of 1970s and 80s economic policy of import substitution industrialisation, but it should be done gradually in line with today's realities. Nigeria could not just go back to those periods; the world has changed. Thus, federal government must take notice of the fact that at the same time government policy makers were trying to revive industrialisation through stopping imports, people were suffering because of their action or inaction such as higher prices and scarcities of necessities. It, therefore, became necessary for Buhari government to adjust in such a way that it did not hurt the poor man that brought it to power.

In an interview with Aljazeera TV, former minister of finance Ngozi Okonjo-Iweala advised President Buhari to concentrate on the goal of achieving macroeconomic stability which involved controlling inflation, foreign exchange stability, and control of fiscal policy. Those that were calling for reverting back to import substitution industrialisation as solution to Nigeria economic problems might also be right. But, these advocates should remember that you could not start producing any substitute without putting the enabling environment on the ground. The needed environment was macroeconomic stability. Nigeria also needed stable power supply, good roads and rail lines, security of investments, access to capital, highly skills workforce, to mention just a few. But, these could not come in a single day they took time before they could be put on ground. Hence, the need for gradual approach to any kind of import substitution policy. Nigeria could not just close its border and said 'let start producing rice' without tractors, fertiliser, sending extension workers to farmers, making loan available, providing good seeds for planting, and so on. If the policy was hurriedly rushed there would be hunger in the land just as it was experienced between 2016-2017. But, Nigeria could have done that gradually as was done in the case of cement production (locally). For example, government could say let reduce import of rice this year by $25 \%$ another year by $50 \%$, next $75 \%$, in the fourth year Nigeria could stop importing any rice, becoming self-sufficient. The later successes achieved in local production of rice, though it was difficult to achieve, came gradually not in one year. At the beginning of his regime, Buhari economic team was thinking like bunch of accountants whose main concern is bookkeeping. We were not supposed to be dealing with how to keep government record properly here (which is accounting matter, though that was also important), but what Buhari team should be dealing with was how to put good economic managers in place who were creative enough to advise government on the most acceptable method of getting Nigeria out of economic quagmire. The minister of finance should be somebody with relevant work experience, knowledge of macroeconomics and not a practicing accountant, who is more or less a bookkeeper. In addition, government should make use of both fiscal and monetary policies to get the economy out of any recession. Under the United Nation Industrial and Development Organisation (UNIDO) classification, Nigeria was ranked lower middle income country, this signaled that demand boosting strategies would work in reviving her businesses back to profitability.

In 2017, about two years into his first tenure, President Buhari started heeding to calls to change the economic direction his government had taken in the previous two years. Already, 
there were positive signs that Nigerian economy was responding positively to government economic stimulus. Price of food stuffs had started to decline, thanks largely to harvest of farm products. In the manufacturing sector there was an indication that manufacturers had started looking inward for local inputs and were retooling their machinery to adopt to local materials as well. Figures from Central Bank of Nigeria (CBN) showed credit expansion in the third quarter (Q3) of 2016, despite the widely discussed lack of liquidity in the economy. Rating agency Fitch had projected Nigerian economy to grow by about $2.6 \%$ in the year 2017, a welcome development. The IMF in its 2016 World Economic Outlook report had rated Nigeria as Africa's largest economy ahead of South Africa and Egypt. This came after Nigeria was estimated to have been overtaken by South Africa in 2015. To salvage the economy from collapse federal government had to initiate the securing of upfront payment from buyers of its crude oil. This was done in order to help built Nigeria foreign reserve and reduced borrowing cost. The government of India was part of the arrangement, planning to pay \$15 billion upfront against future supply of crude oil from Nigeria. The Indian government also benefited from the deal in forms of Indian Companies participation in Nigeria's oil and Gas industry, building of infrastructures, and guaranteeing of future oil supply. Buhari government tried to sell national assets in order to finance yearly budgets, complimenting borrowing from external agencies. These were part of existing innovative methods created to get Nigeria out of recession it found herself in 2016 . Even prominent economists and businessmen as well as former President Obasanjo had, at then, supported the sale of national assets to get Nigeria out of recession.

Multinational institutions such as the IMF (in their regular observations) had warned that any Nigerian economic crisis risked spilling into other West African countries. Nigeria immediate neighbors such as Niger, Benin and Chad had started feeling the impact of Nigeria's economic crisis of 2016. IMF also forecast that economic growth in the whole of Sub Saharan Africa for 2016 would grew by only $1.6 \%$ a figure far lower than expected. One of the major factors responsible for that according to IMF was declined in commodities price that most of African economies depended on and failure of their governments to diversify the economies. But, both IMF and World Bank had expected Nigeria to recover in short duration, which happened as Nigerian economy exited recession in 2017. Figures from IMF put Nigeria's GDP at $\$ 415.080$ billion in 2016, from $\$ 493.831$ billion at the end of 2015, this affirmed Nigeria as the biggest economy on the continent. This came after Nigeria was overtaken by South Africa. The decreasing level of foreign reserve, falling revenue from oil sells, and weak export base had exasperated fall in Naira value against Dollar. Already holders of external loans domiciled in dollar were feeling the heat, as the value of their debt skyrocketed, becoming difficult to service. Those who fallen victims included federal and state governments, Banks and other major corporate entities. I couldn't understand the minister of finance Mrs. Kemi Adeosun at that time, whether she was ignorant of macroeconomics or it was just lack of competent hands to assist her on the matter. In an interview with the media in 2016, he was quoted as saying that "I don't want to predict when we will get out of recession. Let me tell you that we will get into growth and that's how you get out of recession, because of the stimulus that we are providing". With the most advanced 
macro-econometrics packages you have today and availability of reliable data any one could predict when we get out of recession or not, but (anyway) IMF and World Bank had done that, for those who wanted to know when would Nigeria get out of recession.

IMF had also called for more structural adjustment and tight fiscal and monetary policies, though some analysts might have had reasons to disagree with this recommendation in face of need to inject money into the economy in order to pull it out of recession. World Bank on it part had also called for tight monetary policy to help fight inflation, seeing it as a good move to boost real interest rate and attract investment into Nigeria. A Price water house Coopers (PwC) report showed that Nigeria was on her way to become \$1.4 Trillion economy by 2030 on the backdrop of sustained fight against corruption and implementation of good policies. But, Buhari major plus for the future of Nigerian economy has been his desire and determination to build sustainable institutions, a corrupt free Nigeria, as well as his fight to institute property rights. These factors are very important for building of strong Nigeria with equally strong economy. Institutions such as the judiciary, military, police, civil service as well as the business community must be purged of corruption for Nigeria to reach the dream land. Property right on it part is very important for the development of private sector and attraction of foreign investors, because no investor put his money where he is not sure of title of his property tomorrow. With good institutions Nigeria's journey to become one of the largest economies in the world is assured. But, Nigeria's bureaucratic system must be reformed in order to put Nigeria on the top in world bank's ease of doing business ranking. Nigerian judiciary and civil service were the most affected by the bureaucracy virus. Only thorough reforms in these sectors would rid Nigeria off the problem.

Later Buhari government also changed its foreign exchange policy, adopting manage float. Manage float was increasingly being adopted by countries around the world and remained the most popular foreign exchange regime. On the sliding value of Naira against Dollar, CBN hasted to take measures to ensure transparency in Dollar trading. Government also took immediate measures to address the activities of currency speculators who had contributed in fueling the problem. But, in the long run the only way to ensure efficiency in distribution of Dollar is to increase it availability and that will only happen when Nigeria increase the total value of its exports as a major source of foreign exchange. Policies such as the sale of Diaspora remittances to Bureau De Change (BDCs) made positive contributions as indicated by recent improvements in the value of Naira against Dollar. The combine annual remittances from diaspora Nigerians runs into billions of Dollars, therefore policies that ensured maximum utilization of these Dollar remittances are good for the economy. CBN adaptation of Naira-Yuan swap deal agreed on with China central bank, that was abandoned on the way, would help reduce Nigeria dependence on Dollar and restore some level of stability to the exchange rate. Nigeria had adopted the Chinese currency as one of its reserve currencies during tenure of Sanusi Lamido as CBN governor, it is therefore logical to take the relationship a bit further. As it looks now, CBN decision not to lower interest rate is good, as it was done with the intention of helping Naira regain its value against Dollar. As Nigerian stock exchange recovered, more investors returned to the market. For those Nigerians dreaming of Naira returning to its 1980 s to 90 s value they needed to quickly catch up 
with the existing realities, that nothing like that would happen in the next five years. Naira would be judged as doing well if, at least, it returns to its value of 100 plus to the dollar of the last two decades in the next five years. Foreign exchange is a reflection of economic fundamentals which as at 2016 favoured low value of Naira against Dollar.

Federal government needed to get it tax collection system right, because without that all efforts to maximize government revenue would meet obstacles. It was not a matter of charging high taxes but charging the optimal rate in order to allow for efficiency in the process. A situation where tax payers were colluding with tax authorities to avoid paying tax or pay lower than the amount they were expected to pay is bad for any government. Thus, Buhari government needed to wake up and fought the bureaucracy and corruption in Nigeria tax administration. This would have gone a long way in increasing revenue generation and helped reduced deficit in the annual budgets. Agricultural sector required more than Buhari's government was allocating to it, between 2015-2016. if at all Nigeria wanted to diversify its economy away from dependence on oil, higher level of commitment was required from the federal government. Africa's fastest economy Ethiopia, depended on agricultural export for most of its foreign earnings, why couldn't Nigeria did the same. The Nigeria rural agriculture was in very bad shape, rural farmers still used hoe to farm their lands, they could not access fertilizer instead resorted to using manure, and they were ignorant of latest developments in modern farming. Initially, government's agriculture policy was not well spell out, leaving prospective investors in the sector in darkness on directions the government was taking. For production of large quantities of agricultural output, government must develop rural areas and reduced rural urban migration, emphasis mechanize farming, wooed larger private investors into the sector and made funds available for onward distribution to actors in the sector in forms of soft loans and assistance. People should not expect significant improvement in agricultural output without changes in the existing technological and policy bases on which the agricultural sector depended. To reduce current level of unemployment in Nigeria, agriculture and manufacturing must be prioritized. Hence, the emphasis on farming.

The federal government focus on infrastructural development is most welcomed, all major countries of the world that made it to the league of developed nations had first tackled their infrastructural shortages before they reached the point of being called developed nations. Initiative by federal government and World Bank to establish Nigerian Development Bank was timely. With the right kind of infrastructures this government would be able to attract the right kind of foreign investors into Nigerian economy. For example, FDI figure for 2015 was put at $\$ 3.4$ billion which was lower than in 2014 with $\$ 4.7$ billion, a fall of 27 percent, the figure must rise for Nigeria to realise its ambitions. At the heart of previous governments slow responds to infrastructural investment was the long term nature of large capital projects, whereby government that started these projects might not be the one that finished it and enjoyed the benefits. Hence, the nature of democracy which promised short periods for leaders in position of authority. In Nigeria, political office tenure has a two term of four-year limit for all elected representatives of people. The fact that voters on their part were not patient enough also explained the behavior of people in power to projects that brought immediate benefits at the 
expense of long term projects. Though power supply has begun to improve, concrete measures must be taken to ensure it long term sustainability. This would come only with huge capital investment in the sector which normally took long time to materialized. Power projects like Manbila hydro power in Taraba state north Eastern Nigeria, various other thermal power works currently going on must be pursued and finished on time. Renewable and Nuclear energy sources must also be explored in order to meet current and future energy needs. The next two biggest economies in Africa have power generation of 52,811 MW and 24,700 MW for South Africa and Egypt respectively, while the biggest economy Nigeria has only about 4,500 megawatts. This show that Nigeria was far below her actual potential as a nation.

World Bank, IMF and Islamic Development Bank had at various time in the last decade ranked Nigerian economy among fastest growing in the world. Nigerian economy grew despite challenges of insecurity, corruption, bureaucracy and poor infrastructures. Sectors who contributed to the grow were manufacturing, construction, telecommunication, and services who absorbed capital and labour as they churned out higher output. Agriculture grow despite government neglect over the decades. But, the number of poor Nigerians had refused to come down despite government mantra about fighting poverty and unemployment. Conventional methods of fighting poverty have done little to reduce poverty. Past Nigerians governments have been found culpable in corruption cases where billions of Naira of pensioners' money were stolen. Earnings from crude oil has amounted to over a trillion Dollars in the past three decades. Nigeria economy depended on imported fuel to power its vehicles and machineries. Inflation rate rises and falls like growth in the economy. As a result, the economy remained heated causing frictions. Inflation and unemployment in Nigerian economy have remained stubbornly high, in double digits. According to conventional economic theory rate of unemployment should come down when there was high inflation. But, wastefulness at all level of governments hampered prudent management. Wastages, declining foreign reserve, absence of conducive economic environment, and state of the global economy had contributed to the deterioration in foreign exchange. Domestic producers continue to complain about the high cost of Dollar, affecting domestic production where there is reliance on imports. High cost of Dollar had an indirect link to poor domestic infrastructures. Increase in export and reduction in import caused Dollar cost to fall to favorable level that could sustain the economy. The challenges to the grow of Nigerian economy were many. In recent years, security challenge had come top, remaining an obstacle to any kind of growth. Corruption have affected all sectors of the economy, especially the public sector where rent seeking has been the order of the day. Nigeria continued to attract foreign investments due to large market within its borders, abundant human and material resources, and foreign investors desire to diversify their portfolios.

In the past, efforts to bring Nigerian inflation rate to a single digit did not bear fruit, despite promises by Central bank. Different factors were responsible for this, which included high fuel price, politically inclined liquidity injections in the economy by CBN and deteriorated foreign exchange rate. Double digit inflation is bad for young economy. Profit and growth rates of an economy must rise higher for investors to feel comfortable in high inflation environment. 
Contradictory government policies have helped to made inflation rate high. Nigerian inflation rate had remained higher than other emerging economies around the world. Cycle of election spending and surplus budgeting has contributed to this scenario; so also the absence of domestic industrial base that made Nigeria to rely on importations. The history of inflation in Nigeria is full of ups and downs. In the middle of 1970s with an oil boom in the economy the rate of inflation galloped up to an unprecedented level. The military government of the time did not help matters with inflationary policies such as Udoji awards, that put huge amount of money into the pockets of civil servants. Buhari military government between 1983 to 1984 tried to bring rate of inflation down after the excesses of civilian administration, but introduction of structural adjustment program (SAP) by next government left the macroeconomic environment destabilized in search of equilibrium position. Despite economic and diplomatic benefits of return to democracy in 1999, rate of inflation had remained high for most of the period. These undermined governments efforts to entrench macroeconomic stability. Debt reduction policies of Obasanjo from 19992007 had to some extent helped reduce hike in inflation. But, Obasanjo poor budgetary discipline did get inflation out of the way to affect general macroeconomic stability. Corruption and death of infrastructures had undermined efforts to restore macroeconomic stability. Jonathan government also failed to maintain fiscal discipline. Borrowings by his government had crowded out private sector borrowing, making cost of borrowing high. Consecutive budgets continued to multiply in term of monetary value only financed through borrowing, further putting pressure on inflation rate. Between 2009 to 2014, inflationary budgets had made Nigeria looked like country in war.

A presumed independence of the central bank of Nigeria (CBN) in monetary policy, that was hailed at the beginning, has remained a mirage a decade after. History of central bank monetary independence did not start in Nigeria, it started elsewhere in the world when rates of inflation seemed uncontrollable due to politicians continuing tempering with monetary rates in order to achieve political ends. Today, many central banks in the world enjoyed independence in term of monetary policy implementation including the Federal reserve of the US and the Bank of England. The roles Nigerian politicians have played in putting Nigeria in the mess she found herself include the frequent interference with Nigeria central bank. No nation developed when its policy makers could not separate personal feelings from professional ethics, politics from economics. One lesson from East Asian success stories (such as South Korea, Taiwan, Malaysia and Japan) was their abilities to bring inflation under control helping to spur private investments in return. As the authors of World Bank's, THE EAST ASIAN MIRACLE observes, "low inflation is a corollary of fiscal prudence: East Asian governments never had to rely heavily on the inflation tax because their deficits were within financeable limits". Low inflation rate helped to keep the rate of interest low for these countries, thereby helping to spur rapid investments. Fiscal prudence and low inflation helped in controlling movements in foreign exchange rates. Uncertainty about inflation and monetary authorities' inability to fight it generally had negative effect on macroeconomic stability. Banking sector and capital market developments are a must in the modern world for attracting foreign direct investment (FDI) in any developing nation. Nigeria has 
a lot to learn from the so called Asian Tigers. Economic management is not about political gratification and satisfaction of short term ends at the expense of the most needed long term growth and development. At the height of Nigerian government inference with CBN functions, President Jonathan fired his CBN governor Sanusi Lamido Sanusi for exposing the level of rot in Nigerian National Petroleum Corporation (NNPC) in 2013.

Of the main macroeconomic forces that determined fortune of an economy, foreign exchange is top on the list due to its complicated relationship with other macroeconomic variables. Exchange rate, the price at which a country's currency is exchange for that of others, is an important international trade tool. Its stability is such a lofty goal that a government can lost its legitimacy because of it, diplomatic uproar can result from its determination, and in the past, nation had gone to war. The major borne of contention in diplomatic relation between the United States and China in the past two decades has been alleged undervaluation of Yuan by Chinese authorities. Naira determination should be concern of all Nigerians not just policy makers, bankers and economists. Past Nigerian governments have failed to find the right foreign exchange policy. The history of Nigeria's foreign exchange management is record of upswing, policy somersault, and absence of road map to steer Naira in turbulent seas. From the time of independence when Nigeria policies were anchored to United Kingdom (when the local currency moved up and down with Pound Sterling) to today's manage float system, Nigeria has failed to find realistic foreign exchange policy. Determination of foreign exchange is complex process, not a tea party. It cannot be carried out in vacuum, without considering consequences on the economy. Changes occurred to inflation, interest rate, employment, and domestic production as a result of towing the wrong exchange policy. Over the years, CBN efforts to narrow gap between official exchange rate and parallel market has not achieved desire outcomes. In the past, Nigerian banks forgot their traditional duties in favor of making quick money through illicit trade in Dollar.

The CBN decision back in 2016, after it monetary policy meeting, to devalue Naira has changed a lot in the Nigerian macroeconomic environment. The decision has brought to an end the official pegging of Naira at N197 per Dollar by Buhari government which was unsustainable. The cost of that policy could be seen in continuous erosion of foreign reserve which was used to support the Naira (you can also call it Naira subsidy, similar to the use of billions of naira to subsidized domestic fuel consumption), and foreign exchange supply crisis. Like it happened with the removal of petrol subsidy, operators of black market in the currency business disappeared slowly, paving way for possible middle ground between the black market price and the previous pegged value of N197/Dollar. The full effects of the policy would take sometimes to be effective. In the near future, all foreign investors that withdrew their money away from Nigeria would come back. The continuous erosion in the market capitalization of the Nigerian stock exchange was expected to stop and the market rebounded back to previous position of one of emerging market most profitable destinations. With that action, the CBN has nullified the official exchange rate regime of N197/dollar ushering in the era of manage float in increasingly diversifying economy. Today the market is moving together with other major macroeconomic variables toward achieving economic growth and development. Though, a strong Naira is a distance possibility, 
Nigerian monetary authorities shall not rush into use of force to strengthen Naira. Economic forces should be allowed to determine Naira exchange value, not through use of fiat.

The decision to allow market to take its course, is a wise decision that should have been taken by the Buhari government since inauguration on May 29, 2015. It would have saved the government from the embarrassing moments of removing subsidy on petrol and shortly after devaluing the Naira. Because, had the government allowed the market to determine the value of Naira the persistence petrol shortage experienced between late 2015 and early 2016 would have been avoided. As oil marketers would have the opportunity to freely buy the Dollar they needed to import refine petroleum products. The mess created by petrol shortages and the later sudden removal of subsidy would have been avoided. Not only that the imminent recessionary moments of 2016 would have been avoided. The scarcity and shortages, skyrocketed prices of basic things need by the poor, as well as the intervention of the corrupt Nigerian elites in the market by helping to increase the scarcity of things would have been avoided. Policy of rationing of economic goods be it currency, petrol, food, fertilizer, and so on, is opportunity for the corrupt businessmen and government officials to continue with their heinous agendas, business as usual. Buhari's government has achieved a lot in the areas of security and war against corruption. But, one area Mr. President need to focus more is the economy. Mr. President needs a very strong economic team.

Coming back to the issue of recession that Nigeria found herself in 2016, the word recession itself according to Investopedia means, "a significant decline in activity across the economy, lasting longer than a few months". It was visible in industrial production, employment, real income and wholesale-retail trade Nigeria was involved in. The technical indicator of a recession is two consecutive quarters of negative economic growth as measured by a country's gross domestic product (GDP). Due to the economic problems Nigeria found herself economists had started talking of recession right from 2014, taking into consideration the declining rate of economic growth data released quarterly by National Bureau of Statistics (NBS). South Africa, Africa's other biggest economy had entered recession, according to some analysts in 2016 and 2018. 2016 recession was the second time in the last one decade that Nigeria had inched near recession, the other time was during the global economic meltdown of 2007 and its Nigerian version of 2009-2010. The other recession unlike the one in 2016 was as a result of global financial crisis that affected the global financial industry including Nigerian banking sector. As a result, the Nigeria stock exchange collapsed, unemployment increased (including massive sacks by the private sector more especially banking sector), and closure of businesses. But, at that time, Nigeria fall back on her savings and used them to bail the economy out (AMCON was funded from such savings). Unlike in 2016 when there was no savings left by previous administration to fall back on. It was up to Buhari regime to come out with creative ideas of how to get the economy out of the quagmire it found itself. 
Factors responsible for the economic woes, that pushed Nigerian economy into recession in 2016 are:

1- Falling oil price in the international market: oil was the major foreign earner for the Nigerian economy that provide almost $90 \%$ of foreign exchange. It shall be clear now why continued fall in the price of this commodity pushed Nigeria into recession. Unless the country had large savings to fall back on, which Nigeria did not have.

2- Empty Treasury: the central treasury the new administration inherited from the former regime of Jonathan was virtually empty, even former President Jonathan himself declared that he was forced to squandered about $\$ 18$ billion Dollars of Nigerian savings. With empty vaults there was no way government could have any leverage to fall back on when the economy went into problems. Thus, lack of saving is the same thing as saying the government is bankrupt.

3- Global economic slowdown: the global economy had experienced slow grow between 20142016, due to slow down in world biggest economies such as US and China. That explained why demand for Nigeria's major export declined.

4- Political transition: the in-coming government had to sort out a lot of things before it hit the ground running. In the process of doing this there were delays and time was wasted.

5- Delay in signing and implementing budget: the new and the old governments as well as legislative arms should all bear blame for the delay in signing the 2016, 2017 and 2018 budgets.

6- Poor revenues and declining earnings: businesses, the major mover of the economy, had experienced declining revenue and profit due to slowdown in economic activities. This in turn plunged the nation into further recession as private sector employers sacked workers, firms paid small dividend or no dividend to shareholders; as well as made smaller tax payments to the government. This in turn led to fall in government revenue.

7 -Insecurity and violence: the continued violence and attacks on oil facilities in the Niger Delta have no doubt helped caused the depression in the economy. But, government efforts at dealing with Boko Haram insurgency in the North had help restored confidence.

Giving the above listed factors, it would be very difficult for Nigeria to avoid recession in 2016. Two years before official acknowledgement of Nigeria entering recession, both business and consumer confidence had fallen, Inflation rate had moved from a single digit to a double digit. Government was advised to adopt both short term and long term measures to bail out the economy. For the short term measures, the government needed to quickly allow the value of Naira to be determined by the forces of demand and supply instead of being fixed by fiat. The federal government had, since its start in 2015, put measures in place aim at removing wastages and leakages in government revenue that had become notorious with previous governments. Then, government should continue with its fight against corruption, and the amount of money recovered should be used judiciously. Government should immediately release more money for infrastructural project such as building of new roads and railway lines. Government should also 
have devised ways to put money in the hands of people as this would help boost purchasing power and reduce the hardship people were facing. In the subsequent budgets, government had intended to spend trillions on infrastructures construction, this represented huge increase from what previous governments budgeted. Government should make it policies and plans on the economy open, so that the public know about its economic policy and direction. This would help remove the uncertainty that was hanging over the economy as nobody was sure of the next policy the government was going to take. For the long term measures, the government must redirect the economy away from dependence on oil through diversification. The move toward rejuvenating the agricultural sector is commendable and should continue. Likewise, the development of the manufacturing sector and mining of mineral resources. Not long after government started implementing these suggestions than the economy was officially pronounced to have exited recession. What next is to sustain the momentum and return Nigeria into double digit growth as one of the fastest growing economies in the world.

Successes of privatization of public enterprises elsewhere around the world led to the kick starting of machinery of privatisation in developing countries, starting from the 1990s. The strengthen of private sector in countries like Britain, Germany and South Korea lent credence to belief that private sector was good while any business that bears the footprint of government was bad. In general, privatisation is good but it has its own price too, it was only in hand full of countries (mostly developed democracy) that the process was undertaken without citizens paying dearly, in term of corruption and selling of corporations to incompetent people. A good example here is post-Soviet privatisation and liberalization of former communist countries in Eastern Europe. Apart from the selling of government properties at giveaway prizes to government cronies, there was socio-economic hardship caused by the IMF-World Bank engineered program to transform these former planned economies into market economies. Millions of workers from Moscow to Kiev to Warsaw lost their jobs, in addition, there was scarcity of basic good and service that caused prices to sky rocketed resulting in increasing crime and social disorder. Most of post-Soviet billionaires got their wealth from biased privatisation of Russian state properties. Like Nigeria, billions of Dollars' worth of Russian assets were sold to political cronies at giveaway prices. The same thing happened in South America when countries like Chile, Peru, Brazil and Guatemala embraced privatisation and liberalization.

The thievery that happened in Nigeria in the name of privatisation did not come as a surprise. Right from the time the process began in early years of Obasanjo government, it became clear that there was something else to Obasanjo rush to sell government properties than efficiency and economic gains. Now that strategic government assets such as NICON Insurance, ALSCON aluminum smelting company, Nigerian Airways, National power company, NITEL, steel rolling mills in Delta and Katsina to mention but few have all been auctioned off, Nigerians know better. Unlike in former communist bloc and South America where despite the biases in the sale of these companies they are now national champions, the same cannot be said of Nigerian counterparts who are still in sober state. About $70-80 \%$ of the privatized companies were not functioning well. The sale of PHCN, ALSCON, NICON and few others should be cancelled or reviewed with the view 
to structure the term of the deal. Thereafter, these companies shall be left under the care of government. After all who say government cannot run companies. Big companies are still being run by government agencies from developed countries like France, Italy and Canada to Asian giants like China, India and Malaysia. Now that Nigerian government is serious about management of the economy and the attraction of foreign investors into the country, the entire privatisation process shall form part of the process. Any foreign investor expected to commit his capital in Nigeria is interested in what happens to the privatisation program.

For over two decades now, economic activities have collapsed due to problem of poor power supply. Industries that relied on power supply for their activities have either closed down or managed to produce at high cost with generators which ended up eating the margin they used to make during normal time. The promises and expectations from power sector reforms have been eliciting hope and determination on the part of Nigerians, despite the fact that the process has been on and off for decades. Current power sector reform and privatisation was started by former President Obasanjo. Obasanjo finished his eight-year tenure without seeing to the end of Nigeria power problems, Yar'adua came and left without changes in the supply of power. Jonathan, too, came with his own promises and target dates. The root of Nigeria present debilitating power problems can be found in poor planning, negligence, and corruption. When these three evils are defeated Nigeria will say bye-bye to perennial power problems. The road to achieving 24-hour power supply in Nigeria will remain long, until such a time when the powers that be are ready to jettison the culture of quick gain and greed. No foreign investor would be compatible putting his money in a sector where he was not sure of getting back his initial investments, tackles of making a profit.

In the economic sphere, Nigeria has found itself in one of its most difficult and unpredictable moments right from the days of Structural Adjustment Program (SAP). The global economy has been ill since after financial crisis of 2008, described as biggest economic crisis since the great depression. Economies everywhere around the world from Peru to Vietnam, Iceland to South Africa were in serious trouble, outcome of financial crisis that originated from Wall Street. In Nigeria the story has not been different, from weak stock exchange, deteriorating exchange rate, high interest rate, growing fear about health of the banking system, unfavorable term of trade, rising inflation, unemployment, to increasing poverty level. Governments everywhere were taking measures aim at tackling these problems. During the days of former President Obasanjo in office, Goldman Sachs (a US global investment bank) in its usual global survey and forecast come out with a report that looked at the world in 2020. Nigeria was included among 11 economies in the world with potential to be among twenty largest economies in the world by year 2020.This is how the most popularized Nigerian government Vision 2020 originated. The realization of the vision hanged on many premises, that included GDP growth of more than 6\%, annual investment of 10 Billion Dollars on infrastructures, Macroeconomic stability among others. The Goldman Sachs forecast was inspired by the astronomical growth in the global price of Crude Oil before the occurrence of 2008 economic crisis. It was crude oil export that helped explained the outstanding growth in Russia during the same period. And the same Russia was 
included among BRICs (Brazil, Russia, India, and China), coined by Goldman Sachs, as countries with potentials to rival US economy. When the price of Crude Oil crashed, Russia was (at a time) no longer seen as part of BRICs by the same group of people who earlier made noise about the potentials of BRICs. As a result of the 2008 crisis, even Goldman Sachs, with a record of over seventy years of investment banking, was devastated by the global economic crisis. It was forced to convert into Retail banking, and went begging for money from a US government economic Stimulus package. Goldman Sachs was temporarily nationalized and forced to rethink its business model.

The economic growth and development experiences of Brazil, Turkey, India and China were driven by the real sectors of their economies. The financial industry in china was one of the most underdeveloped in Asia when this started to happen some two decades ago, yet because of investments in real sectors of its economy China had achieved rapid economic development. China did not rely on one export commodity as sourced of growth. It had a highly diversified economy that moved from reliance on primary industry export to export of manufacture products. It experienced phenomenal growth in infrastructures, and primary and secondary school enrollment. Agriculture experienced rapid growth in both output and productivity that led to improvements in the living standard of rural dwellers. There was effective public administration. These were augmented by government investment in applied research, good macroeconomic management, and effective subsidy to key industries. Nigeria, on the other hand, had started on shaky ground two decades ago. The military was about to leave power due to the sudden death of military dictator general Sani Abacha. Nigeria was at that time sidelined by Western powers. It was entangled by vicious inter-ethnic rivalry and poverty. Nigeria single most important export (crude oil) traded at very low price of about $\$ 18$ per barrel. Infrastructures were in bad shape and national production of electric power was declining gradually. The financial sector was tiny percentage of the economy and just like the public sector it was inefficient. It was twenty years later that Nigeria started to implement some of the policies put in place by the countries mentioned above. With rapidly growing population, Nigeria is gradually coming to her senses looking at the danger that lay ahead if the necessary and urgent measures are not implemented today. There are also positive prospects awaiting Nigeria in the near future if the right policies are put in place today.

Nigerian leaders were left with huge economic problems at hand, most important of which is poverty. While president Jonathan had a lot of surplus cash which he mismanaged, president Buhari has meagre cash surplus and struggled to select a viable economic policy at the beginning of his tenure due to his earlier underestimation of the problems at hand. President Buhari political economy was derived from his believe in the principles of elimination of wastages, economic self-determinism, productive investments, equity, and long term savings. It is different from what Nigeria have in the recent past in the so called Nigerian version of American liberal economic model that failed to learn from the positive economic changes that had taken place in America itself in the past hundred years. But, Nigeria failed economic models found partners in domestic corruption, tribalism and absence of sympathy for the poor. In the past, government 
official boasted of achieving economic growth; that their governments aimed to achieve economic growth so as to enter league of biggest economies in the world. But, how could that economic growth be achieved? Economic growth without development, championing pauperization of majority by few, acting as a harbinger for development of cabals who controlled both political and economic power? Neo-liberal models as seen in the post-communist Eastern Europe caused economic and social complications. It enriched few powerful groups by means of sale of government assets. The recent obsessions with creation of richest individuals on the continent, its biggest banks, or tallest building should not be Nigerian policy makers only targets. Like a famous development economist professor Dudley seer has rightly observed, the main questions that should preoccupied the minds of economic planners should be what is happening to poverty, inequality, unemployment? When these are reducing we would now talk of economic development.

What differentiated Buhari from contemporary Nigerian leaders is that Nigerian poor saw him as committed leader who abhorred corruption and injustice, a moral crusader. He promised to deal with exploitative capitalists and crook business people, making them to pursue their business interest in line with national interest. But, according to his past speeches, Buhari was not a socialist; he only wanted to see business conducted in accordance with the law. Free enterprises economic system, as practiced in developed countries around the world, is the better economic system when compared to socialism or communism. It allows freedom of trade and individual right to own property assets. But, as good as it is, it needs strong government and civil institutions to function well or else it will result in anarchy and exploitation of the weak by the strong. In a country where corruption, rent seeking and bureaucracy has eaten into the foundational base of the economy, not any kind of government economic machinery could bring needed scour to relief the nation's people from clutch of power hungry cabals. For free and fair competitive environment there must be strong judiciary devoid of partisan politics and corruption, strong government headed by accountable team, property and copy rights, fights against corruption and rent seeking, and access to finance. The rich few enjoyed dividend of democracy at the expenses of the majority poor.

After subduing Boko Haram insurgency in the North, President Buhari major challenge was in the economic front. After the jittery start in the management of the economy, Buhari could not afford to continue along the line started in the first 18 months of his government, as it would prove costly for the government. After independence in 1960, agriculture was the most important earner of foreign exchange for Nigeria. It was neglected by subsequent governments when crude oil was discovered in commercial quantities. Since coming to power in 2015, Buhari has started to look for alternatives in the face of lower international price of crude oil. Agriculture provided that 'immediate' alternative, taking into consideration the role it played in the past and the number of Nigerians that still depended on it for living. Hence, agriculture was single out for special consideration. But, should Buhari take sectors like education, agriculture, infrastructures, and so on, just like any other sector, NO. Agriculture should be treated as special area - a strategic sector. Without that, whatever bad happen to the sector would spill over to the economy through 
higher inflation (high price of food) and lack of local raw materials. Up till around 2017, Buhari was yet to have concrete blueprint on how to turn the sector around and if he had one at all he kept it close to his chest. But, the earlier his team got a road map for the sector the better for the Nigerian poor who depended on it so much. Now that Boko Haram crisis has been reduced to the lowest level possible (or to use the President word 'crush'), Buhari attention should turn to Economy! yes Economy!! Economy!!! Because his success depended on it, not any other things he told Nigerians. Rating agencies had commended the government success in maintaining a strong balance sheet despite having turbulent economy, when compared with peers in the same condition. But, Nigerian banking sector needed attention of his government in order to help make other government objectives (that were connected to financial sector) achievable. The lending level by the banking sector was below capacity, hence, government must provide incentives to enable the sector to lend more. Central Bank of Nigeria should have considered reducing the interest rate, taking into consideration the situation of manufacturers and small scale industries.

As many analysts have observed Buharinomics comprised old economic ideas that were tested during the 1970 s and 1980 s central focus of which was nationalism and self-reliance. Pursuing industrialisation and self-reliance were not bad in them self, but where the problem lies was the method used in realising the objective in today complex world. A financial times article described Buhari economic policies as replica of "Venezuela's exchange rate policy and China's failed equity market strategy". Though, Nigeria foreign exchange problems would not just banish as we wanted them to do, Buhari needed effective way of managing them in the short run so as to reduce the hardship caused by the scarcity of Forex in the wider economy. But, that was not done until later on. Thus, of priority should have been the need to find solution to the then notorious problem of rationing of Dollar. Our system as it was could not be relied upon to distribute scarce dollar to those that needed it, corruption, and bureaucracy stood in the way of achieving any desired objective. The unnecessary shocks that Nigerian economy had gone through would have been avoided had Buhari planned well at the beginning of his tenure and did not take the economy for granted with appointments that could well be term as mediocre (cases of ministers learning on the job). Just like with any other human endeavor there was no alternative to recruiting the best hands, people who were experts in their fields to advice the government. Next time president Buhari is changing his cabinet, he shall look for competent hands to manage the economic front. Buhari's pre-inauguration state of mind, that Nigeria of today could be put on rapid economic progress with 1970s and 1980s economic models, not minding that things have changed would not work. Economics as a discipline in itself is more dynamic than what Buhari thought it to be, models of 1970s/80s have been improved upon since. More advanced successors that could handle today economic complexities better were available and President Buhari had no excuse for not looking for them.

Links between economic growth and development of higher education have been emphasized by many past academic studies. For example, a study by London school of economics noted that doubling the number of universities in a country resulted in increase in GDP of about 4.7\%. At the start, it seemed like Buhari government's advisers were not aware of this connection, 
looking at their slow responds to the demands from the education sector. Just like Buhari saw the need to develop agricultural sector, he also must notice the need to develop education sector, for Nigeria to achieve economic growth and development. One of the immediate benefit of doing so was reduction of pressure on foreign exchange as the number of Nigerians going abroad for higher education would come down. There was no alternative to having the right people to manage Buhari agendas and made sure they were implemented right. Despite later efforts responding to cries on how his government handled the economy, Buhari should have gotten more experts on economy on board to help advise him on how to run Nigerian economy. There were insinuations in the media that some of the ministers Buhari recruited have failed him. It, therefore, become necessary for him to appoint competent advisers to assists in handling the economy and other strategic sectors. The whole world must see Buhari fulfilling his promises to fight corruption no matter who was involve. Whether that person was in his government or outside of it, big or small.

When President Buhari made his first budget presentation to the national assembly in 2015 he apparently was unaware of the politics and corruptions that went with passing of budgets through the two chambers of the national assembly. Buhari state of mind was formed under the wrong impression that budgets were normally scrutinized diligently and pass over to the president in due course for implementation. Alas, the honorable parliamentarians had different ideas on their minds. By the time the first, second and third budgets were passed it was already middle of the year on each occasion. The first year, people in budget office (including the director) had to lose their jobs as punishment, while the national assembly went into crisis due to the budget padding, and Nigerian economy was put on the brink of recession. No budget has ever reached full implementation level by its official year end, due to delay in approval from the national assembly and slow implementation later. Despite that, Trillions of Naira worth of capital projects were executed between 2015 to 2018, a record in the history of Nigeria corrupt budgetary process. Buhari government had continued to pump money into capital projects. One could notice the increased in the number of infrastructural projects being undertaken by government from roads, railways, power to airports buildings, as well as increase in commitment toward human development and social projects.

In term of budgeting for development, Nigerian government can learn from the example of China, Malaysia, Singapore and South Korea in the 1980s and 1990s. How they were able to maintained rapid economic growth with equity? According to authors of 'the East Asian Miracle', they combined rapid demographic changes with dynamic agricultural sector and rapid export base. They also maintained macroeconomic stability with human capital investments, strong institutions and effective legal framework. At the start of his government, President Buhari has shown his old conservatism in managing the Nigerian economy in the midst of cash crunched and falling global oil price. One area that Buhari was doing well was in creation of strong institutions and legal environment to ensure corruption free atmosphere for rapid economic growth and development. Looking at the borrowings arrangements of his government over the years one could rightly say that Buhari government would not back away from deficit budgeting. Deficit 
budgeting was not bad in itself in as much as the borrowed money was put into the most productive sectors of the economy that would quickly facilitate the creation of conditions necessary for smooth repayment of the loan and the general development of the economy. Nigerian government should find its economic priorities and focus on them as time is of essence here.

Buhari needed to expand his cabinet in order to bring about flexibility and speed of execution of projects and delivered on the promises he made before the election of 2015; but that did not materialised. Looking at Buhari entire cabinet there was scarcity of business people, not only in role related to business and economy but other roles. This could not compare to past cabinets of Obasanjo, Yar'adua and Jonathan. Analysts had associated the composition of Buhari first cabinet with his lack of business experience and past military career history. Hence, the President romance with retired security officers, journalists and bureaucrats. Unlike Buhari, Obasanjo had been involved in large scale agro-business ventures. His Otta farm has been described as one of the largest commercial agriculture farms in Nigeria. The Buhari economic management team had as its head, the Vice president Yemi Osinbajo a lawyer by profession, likewise Minster of budget Udoma Udoma who was also a lawyer though he had some business and financial experiences, Minister of finance Kemi Adeosun though with first degree in economics was widely seen as less qualified to hold an important ministry like finance looking at her past work history, Minister of trade and investment Okechukwu Enelamah was originally a medical doctor who later earned an MBA from Harvard and ICAN membership. Compare this with past cabinets, former President Obasanjo had produced something akin to US economic team. His team, starting from finance minister (Mrs. Ngozi, Okonjo-Owella), President economic adviser (Soludo, later CBN governor), and Director debt office (Mansur Mukhtar), and so on, were all top economists with degree qualifications up to PhD in Economics. It was said that in constituting his economic team Obasanjo was, at one time, advised by World Bank consultants among others. Hence, all the three cabinet members listed above were involved with multinational finance corporation such as World Bank, IMF and African development bank, at one time or the other.

In the United States, Council of Economic Advisers (CEA) is a United States agency in the Executive Office of the President in existence since 1946, it advised the President of the United States on economic policy. Among its functions were provision of an objective empirical research to the White House, and production of the annual economic report of the president. The US tradition of appointing members into the economic team has been characterized by invitation of respected economists, most of them academic economists working in top US universities. In most cases because their assignments involved technical areas of economics, politics was put aside when appointing members. Likewise, only those who are professional economists or working in related areas (but not individuals with no any business with data/econometrics) were invited. Normally, the President nominate the chairman of the council while the senate confirm him. The US president Donald trump who himself came from the business sector appointed businessmen into his economic advisory team. Though, there were criticism on the domination of the team by Billionaire-businessmen over academics and intellectuals. Thus, what we had in Nigeria was not 
an economic team in the sense of what is obtainable in the US. If one looked at the performance of the ministers in Buhari economic team, all of them could be described as moving at slow phase. They were as well not very creative as expected of people responsible for putting the Nigerian economy in position as one of the most dynamic emerging economies in the world. Though, in fairness to them they had found themselves in the general climate of sluggishness and cautious approach of new government that took over from an opposition party that was widely seen as corrupt. The recessionary business climate between 2016 to 2017 did not favour them either. Unlike Obasanjo's or Jonathan's ministers who found themselves splashed with cash from booming crude oil export of their respective periods.

\section{Economic growth and human development}

It was Karl max, the $19^{\text {th }}$ century German Philosopher cum Economist, who in reaction to a book written on poverty title, 'the economics of poverty', quipped that the right title of the book should be, 'poverty of economics'. The same drama was in play in the case of Nigeria growth models. A situation of growth with poverty, caused by failed economic models and poor leadership. Over the last two decades, Nigeria has achieved average economic growth of about $3-4 \%$. But, poverty rate has become unresponsive to politicians claims of fighting it. The growth inducing economic model used by Nigeria has championed rapid economic growth over equality, development of urban centers at the detriment of the rural areas, consumption over production, individual over community, and exceptional drive for accumulation of wealth by all means including fraud. Poverty has become part of Nigeria from independence to date. Chronic poverty is visible in Nigeria's rural areas that carried most of Nigeria population. Nigeria has been a top foreign direct investment destination in Africa. Nigeria a land of contrasts! Corrupt businessmen connived with those in position of authority to steal the country dry. Less endowed countries around the world have turned their economies around. The conventional economic models Nigeria used in the past were unsympathetic to plight of the poor. But who cares, it has been about 'survival of the fittest', 'the ends justifying the means'. In the World Bank-IMF neo-classical grow model, the poor were not to be taken care of until in the long run when the rich and the powerful had enough. But, the poor is dead by then, as the famous British economist John Maynard Keynes famously observed. The Nigerian elite enjoyed this model so much; since it had no room for kindness, benevolence, sympathy, and generosity. It was said that the model is a scientific model that did not mixed ethical considerations such as equity, generosity, and sympathy with scientific consideration such as wealth accumulation by few. But, the model was at home when romancing with corruption and electoral manipulations. Nigeria is blessed with human resources in all areas of development. It has abundant Natural resources. The only ingredient missing in the equation is leadership.

The rate of poverty in Nigeria was put at around $70 \%$. But, this paradox was not restricted to Nigeria alone. It is paradox of the capitalist economy the world over. Growth in the midst of poverty, jobless growth, high inequality, wealth concentration in the hands of $5 \%$ of the 
population, wastage on the part of the richer echelon of the society while the poor hardly find something to put in their mouth. Corruption that bedeviled all the sectors in Nigeria made this paradox apparent. Late Nigerian Professor of economics Sam Aluko once observed that corruption distributed income in favour of the rich further widening the gap between the rich and poor. Nigeria might have achieved growth of 7,6 or 5 percent in the past but at the same time welfare of the poor had stagnated at the rate of 14, 12 or 10 percent annually. Though, rate of growth as measured by the World Bank might have increased but, measures of welfare as released by United Nation Human Development Index showed otherwise. Nigerian schooling system was no better as it churned out half bake graduates into the labour market, further reducing their chance of getting job that would ease their hardship. The bulk of Nigeria's wealth was circulating between major cities such as Abuja, Lagos, Port Harcourt, Kano, Kaduna, while rural dwellers were left to die of poverty and starvation. In such a scenario poverty has gotten a perfect environment to grow and spread all around Nigeria. Education that should have served as channel of empowering the children of the poor had been abundant left at the mercy of unqualified teachers. Children of the rich, in the meantime, were taken abroad to study in expensive schools. It would take a lot of hard work for any leader to take Nigeria out of poverty. It is something that would be difficult to achieve within a short period of time.

The Nigerian banking system is a poor measure of financial deepening (the percentage of the population with account in a bank), as a matter of fact more than two third of the population were out of the banking system, making it difficult for the poor to access credit. There was no genuine welfare system as found in Europe or the Middle East. Education is not free, it was only partially subsidized at some level, likewise in the provision of healthcare the poor had to find money to pay for his medical bills. To produce anything, a manufacturer had to do most things himself, generate own light, employ security guards, built roads, dig a borehole, and in some cases contribute to build a community clinic. Government poverty alleviation schemes were not working, instead money meant for welfare of the poor were stolen by crooks' government officials who used the proceeds of the loots to send their children abroad for studies and went outside of Nigeria for medical checkups. At the level of state governments, most governments were not doing what was expected when it came to welfare of their people. In an economy crippled by lack of electric power, bad roads, insecurity, high interest and exchange rates, and lack of foreign investment, it beats imagination to talk of creating jobs out of the blue. This state of affairs has been going on for decades with not much done to addressed the situation. After independence in 1960, Nigeria was ranked alongside South Korea, Brazil, Malaysia and Mexico as countries with good prospect of transforming into advanced manufacturing nations. Today, all but Nigeria have achieved their potential targets within the shortest time possible.

Nigerian government should help set policies right and helped in creating entrepreneurs and startups. Job creating sectors like manufacturing, agriculture and mineral resources had helped countries like Brazil and China to create millions of jobs. While unemployment has been falling in poor countries, Nigeria was stuck in a situation of rising joblessness due to poor government policies. The information technology industry that was credited with creating millions of jobs in 
India and the US had not materialised in Nigeria. In recent years Ghana has created thousand jobs in addition to poaching Nigerian talents and companies to Ghana. Ghanaian authorities had put things needed to create jobs in place. They provided electric power, their roads were in better shapes, they were politically stable compared to their neighbors and their macroeconomic fundamentals were good. In Kano Nigeria, for instance, out of the hundreds of industries established in the previous decades, only percentage of the number were working. If Nigerian government were to focus on generating power, building of good roads, provision of securities of live and properties, creation of genuine democratic space and putting of enabling macroeconomic environment in place the better for job creation. Wasteful expenditures remained the problem at all tires of government, despite inclusion of technocrats in government fiscal indiscipline was absent. These factors had militated against achievement of economic growth and development in Nigeria. Problems such as oil spillage in Niger Delta, soil erosion in south east Nigeria and desert encroachment in the north had caused catastrophic damages to the lives of poor people living in these areas. As seen elsewhere around the world, Nigeria had gotten herself into a dilemma of chosen between caring for the environment and achievement of rapid economic growth. This phenomenon was at the heart of the violent in the Niger Delta region, where farms and river waters had been polluted in the process of producing crude oil for export by the Nigerian government base in Abuja. In the lake Chad region, the drying of the lake and the fast approaching desert had increased level of poverty, making it easier for the violent group Boko Haram to recruit fighters.

Nigerian presidents had learnt to change strategy to suit various environments and demands of global community, back in 2016 during an African Central Banks Governors meeting in Abuja, President Buhari told participants that his government would not bow to any pressure from IMF and World Bank in order to do their economic bidding in management of Nigerian Economy. He equally warned other African countries against accepting economic prescriptions from the two major financial institutions or any other external pressure. This came amid growing concerns on the way his government was managing Nigerian economy. This state of affairs had since changed, Buhari had become opened to economic prescriptions that would get him out of the situation he found himself. In a situation where leaders were faced with serious domestic pressure (on the economic front) they could not be in position to give economic advice to others. This was what Mr. Buhari later on realized, that he had to put his house in order first before trying to solve other African countries economic problems. That way, other countries would learn from his perceived economic management prowess, and rushed to accept advices he offered. There were not much differences between Buhari economic policies (of course, after changing course from his disastrous early start) and what IMF-World bank were asking developing countries to do, except for his initial refusal (when he came into power in 2015) to liberalize the foreign exchange market and increase domestic price of fuel. Since his government has done all that IMF had earlier advised him on, he looked like any other African leader who accepted IMF advices. Lists of IMFWorld Bank policies in his government economic programs included: government refusal to subsidize fertilizer used by rural farmers despite earlier government call on people to go back to 
farm. After all, Buhari was not the socialist some people mistaken him for. He was never reported to be asking government officials to release (free of charge) foods kept in government stores around the country to Nigerian masses who came in large numbers to vote for him during election periods. His own children schooled abroad, instead of studying in government own schools.

Nigerian leaders seemed to be obsessed with foreign qualifications and first class graduates in appointments into key positions. Former presidents Obasanjo, Yar'adua and Jonathan had all made used of foreign trained Nigerians as ministers and heads of key government parastatals. President Buhari was not an exception in anyway. His own children were trained in UK and he also frequent the country for his medical needs. In his first appointment in 2015, his finance minister had a Bachelor degree in Economics from UK, though she was an accountant by practice. His economic adviser was seen as someone who lacked the needed working experiences to turn Nigerian economy around in moment of crisis; though he studied in UK. Dr. Adeyemi Dipeolu last post before being appointed economic adviser was as Director of Capacity Development at UN Economic Commission of Africa, based in Addis Ababa. He has spent most of his working career as diplomat working in the Ministry of Foreign Affairs, not in any serious economic role. But, Buhari CBN governor studied in Nigeria up to the level of masters. Unlike the previous two CBN governors before him, he did not have much academic teaching and research experiences. But, his advantage was in commercial banking experience with Zenith Bank plc, where he was the managing director before being appointed CBN governor by former president Jonathan. In an era when large economies were being managed by highly qualified economists, as finance ministers, economic advisers and trade and industry ministers, Nigerian leaders tend to look at other things. The US led the rest of the world in appointment of highly qualified professionals and academic economists to serve in government economic teams. Past members of US economic teams were egg-heads who had distinguished themselves in their respective fields. They include past Nobel prize winners such as Samuelson, Friedman, and distinguish academics like Bernanke.

From Boko Haram crisis to economic crisis back to insecurity issues, Nigeria's problems looked like they would never end. Not long after coming to power, the All Progressive Congress (APC) had accused the previous government of People Democratic Party (PDP) of deceiving it by providing false information in their hand over notes. APC alleged that PDP government gave the impression that Nigeria's economic problems were not severe and economic growth projections were on course. But on deeper look, the newly sworn in government found out that the financial hole left by Jonathan government was deeper than it was portrayed in the handing over notes. Jonathan regime alone was estimated to have earned some 51 trillion Naira in its five and half year history. This total amount of money had never been realized by any civilian government before him. This was made possible by large oil revenue. But most of it was wasted with not much to show in term of infrastructures, education and human welfare. Nigeria was again overtaken by South Africa as Africa's largest economy in 2016, then some months after, it took back the leading position in Africa. But, whether Nigeria's economy was bigger than South Africa's or the other ways round, in term of real economic development South Africa was ahead of Nigeria. 
Economic development and uprooting of Nigerian poor out of poverty should be the main concern of Nigerian governments. In 2016 to 2017, when recession continued to bite hard into people lives, Buhari economic team had to propose the use of emergency powers to deal with the economic problems. It was akin to what the US did after it was hit by financial crisis in 2007/2008 - using stimulus packages to ease fiscal tensions and pumped money into the larger economy. Among measures proposed by Buhari economic team were, released of trapped UBEC fund to state governments in order to boost education expenditures around the country, increasing government contract mobilization sum from $15 \%$ to $50 \%$, increasing Nigeria competitiveness and ease of doing business by faster issuance of visas to foreigners, as well as leasing or selling of government's assets to raise around $\$ 50$ billion for financing government projects. Two years after proposing these measures, the economy gradually bounced back from recession and the hike prices of foodstuffs and other essentials began to come down.

President Buhari and his Chinese counterpart, had agreed in 2016 on a plan of exchanging Chinese Yuan for Nigeria's Naira, what is called currency swap. Buhari spokesmen had told a press conference in Beijing that Nigeria and Chinese authorities had agreed on the plan. The plan would help check the foreign exchange crisis facing the government of president Buhari. It would checkmate the influence of Dollar on Nigeria's foreign exchange transactions, particularly billions of dollar worth of transaction between Nigeria and China. But, immediately President Buhari returned to Abuja his government denied ever signing such a deal. What caused the denial? Observers had noticed that a day before the denial, President Buhari met a powerful delegation from the United States government where they discussed issues between the two nations. Thereafter, the conclusion people derived from the alleged meeting was simple, though president Buhari desired to show the world that he was as tough as when he was military President, by doing whatever he thought was in his country's interest. But, he was also very aware of global powers interests, particularly the economic interests of the US. But, this was not new in politics, even major world powers like the US played politics depending on the scenarios they found themselves. Double standard and hypocrisy is the norm in international diplomacy. The problem many Nigerians might have had with President Buhari was that long held perception of him as someone who dislike hypocrisy even if it was necessary in order to achieve nationalistic aims. Thereafter, it took two more years for Nigerian authorities to start implementing the swap agreement reached with the Chinese authorities.

\section{$\underline{\text { Inflation and public debt }}$}

Public finance deals with government revenues and how it spends them. Like the discipline of economics, it was conceived to put economic sense into countries management of their resources. In Nigeria, the sub-Saharan Africa largest economy, public finance has been ravaged by number of problems. Government sources of revenue in Nigeria include (primarily) revenues from oil export, custom duties, taxes especially corporate taxes, and royalties from mining activities. It expenditures included among other things capital expenditures on infrastructures, 
day to day government expenses, foreign assistances and donations, and so on. Debt was another source of government money income, albeit, a different source. In developed countries, debt is an important source of money for bridging gap between government revenues and expenditures. In Nigeria, debt money was in the past used for something else. Three decades before, the 1980s and 1990s were unique in the history of Nigeria. They are decades during which Nigeria experienced falling revenues, due to falling price of crude oil and the decline of agriculture as source of foreign exchange. Throughout the period price of crude oil hardly rose above $\$ 20$ per barrel. Buhari military regime (1984-85) despite falling revenues of his time, for instance, had tried to repay the debt Nigeria owed foreign creditors. On the other hand, President Babangida regime (1985-92) was accused of mismanagement of Nigeria foreign debts. Massive corruption was major factor behind deterioration of Nigeria economy at that time, where government foreign earnings and borrowings were put into questionable uses. Introduction of structural adjustment program (SAP) with aim of removing Nigeria from the fiscal mess it found herself did not help matters either.

The coming of civilian regime in 1999 coincided with period of rising price of crude oil in the international market, when crude oil price moved from $\$ 18$ per barrel to as high as $\$ 146$. It was alleged that the money earned from 1999 to 2007 was more than all the oil revenues earned from 1960 to 1999. Despite the oil windfall, Nigeria economic situation did not change. Out of the total oil money realized, the civilian regime did indeed secure debt relief in exchange for payment of about $\$ 16$ billion to foreign creditors. About a decade later in 2015, Nigeria major creditor the Paris club started to return some money back to Nigerian government, as the amount said to be paid during Obasanjo time to settle Nigeria debt was above the actual settlement amount. Despite high oil price, Nigeria excess crude account had depleted between the periods of January 2009 to July 2010, from $\$ 20$ billion to $\$ 460$ million. Nigeria foreign reserves had drop from $\$ 64$ billion in August 2008 to $\$ 33.71$ billion in October 2010. The billions of Dollars Nigeria borrowed in the 80s and 90s were not used to assist Nigeria to realize her developmental aspirations. Normally, there are costs as well as benefits from borrowing within a country's own borders. By restricting borrowing to internal sources a country is avoiding the risks that arise with borrowing in foreign currency, the exchange rate risk. For instance, in a situation where Nigeria debt is in Dollars, that means Nigeria has to repay back in Dollar. A depreciation in Naira or appreciation in Dollar will increase the cost of repaying that debt. Unlike when the borrowing was in Naira (like federal government bonds) it will be repaid in Naira without exchange risk. External borrowing also comes with strings attached. Borrowing from institutions like IMF and World Bank come with conditions which might not be favorable to the borrower. The fact that debt transfer power from borrower to lender made foreign borrowing tricky. The debtor country became subservient to external powers mostly Western countries.

Then come interest rate risk, the interest risk that goes with borrowing from international lenders is of two kinds, the cost that goes with unfavorable rating from international rating agencies; Nigeria had in the past faces down grading by Fitch and S\&P, international rating agencies. The implication of down grading is that Nigeria borrow at higher rate than when it 
received favourable ratings, therefore, making borrowing costly. Then the rate itself, whether it is fixed or variable, a fixed rate means that a country would be paying certain fixed rate no matter the economic circumstances, while variable rate varies with economic condition. In determining the nature of the rate the lender has upper hand, as the saying goes a beggar have no choice. In general, the rate charged by international lenders is not favourable to a developing country like Nigeria as it is exploitative. High interest rate was the major cause of third world debt crisis of the 80s when debtor countries mostly in Africa, Latin America and South Asia failed to service their debts. Borrowing internally has one major defect "crowding out effect", which is particularly serious in capital starved economy like Nigeria. It could rightly be argued that the massive government domestic borrowing of the last decades has contributed in making capital very expensive. That means CBN reform and global crisis were not the only ones to blame for the scarcity of capital in Nigeria. People had preferred the safety of government bonds to the uncertainty of Nigerian equity market and banks. Thus, the argument put forward in the past of Nigeria not reaching the minimum borrowing limit of $25 \%$ did not arises, in as much as any substantial borrowing would contribute in reducing private sector rate of growth. It has been shown in academic studies that increase accumulation of debts had the tendency to slow the rate of economic growth. And in many cases, countries borrowed thinking that favourable economic conditions would allow them to service the debt later, no matter the rate of interest charged. But, it would turn out that their forecasts were wrong making nations to end up with dry sources of revenue, thus failing to service the debt. Government shall concentrate on searching for more sources of revenue generation. Look at the abundant mineral deposit scattered all over Nigeria, from Gold, Iron ore, Coal, limestone, Uranium to Tin; Nigeria is richly endowed. Natural resources were major sources of foreign exchange for countries like Australia, Chile and Norway. In agriculture the potentials were there, why not explore them instead of looking for unnecessary debt burden. Nigeria had Cocoa, Cotton, Groundnut, Rubber, Coffee, Sesame, Gum Arabic, as well as hide and skin; they were very good sources of revenue. Why not put the house in order and attract foreign direct investment? These were better alternatives to debt because taking debt did not help Nigeria in the past and it would not do now. Simply because debt money was easy money at the time of borrowing did not means Nigeria should always resort to it. Critics have accused Buhari government of accumulating huge debt for Nigeria.

On Nigerian inflation and factors that might have caused it, many questions remained. For example, is the perennial agitation for minimum wage increased by labour unions justifiable? This is question many Nigerian sometime asked. From an economic point of view, continue wage increase is not justifiable in fact it is ruinous to an economy. There are two main consequences of continuous wage increase, general and persistence rise in the price of good and service, and reductions in the number of jobs available. Frequent increases in wage have the tendency to become an inflationary shock that is associated with sudden increase in the general price of good and services. This is what had been happening since the agitation for wage increase in Nigeria became an annual event. At one hand, the demand for wage increase force producers to increase the price of good and services in order to cover the cost of the wage increase, what economist 
called wage-cost push inflation. On the other hand, the mere expectation of increase in wage makes traders' mouth to salivate on the coming prospect of increase purchasing power on the part of workers. Therefore, making traders to move the prices of good and service up. In general, higher inflation is not healthy for any economy, it is associated with distortion in price mechanism that acts as signal to investors, consumers, producers and even policy makers. Inflationary shocks like the upward movement in salaries and wages without associated rise in Gross Domestic Products (GDP) produce no increase in real wage, therefore, leave workers where they were before the increase. No foreign investor will put his money in a country where the rate of inflation is going up, on and on, for fear of erosion of profit margin. The most attractive destinations for foreign investment around the world were known for low rate of inflation and fiscal prudence. The production of goods and services in an inflationary economy tend to be tricky as producers have to base their operations on inflationary expectations in order to avoid operating at a loss. It is in order to have a firm grip on inflation, that economies around the world granted autonomy to Central Banks in matters of monetary policy. But when wages are on the increase without corresponding increase in productivity as it happened in Nigeria, the monetary policy and indeed macroeconomic policies shall be call to question.

Where an economy is characterized by history of high inflation, unstable macroeconomic environment and lack of budgetary control, the resulting runaway expenditures will cause economy woes. Truly Nigerian workers deserve better than what they were getting. But should that be only through increase in money wage? Why workers did not demand for improve working condition so as to boost workers' productivity? Nigerian labour needs to work hard to present themselves as champions of public rather than defenders of their pockets. Over the years Nigeria has become a nation of increasing labour supply in a highly segmented labour market. But when that is compared with the rise in unemployment in the country, a different image appears, that of a nation whose labour market is highly biased in favor of those who know somebody who is 'somebody' in the government. While labour unions were busy lobbying for hike in their wages, hundreds of thousands of graduated languished in the labour market going helter-skelter from one corner to the next looking for jobs which did not exist. Are Nigerian labour unions blinded to this reality? In academic economics, there was the popular Philips curve, which explained a relationship between increase in money wage in one hand and unemployment on the other hand. It said that the higher the increase in money wage the higher would be the unemployment rate. Though, this relationship does not happen all the time, there were cases of stagflation. At what point should Nigerian labour sacrificed increase in wage for government commitment to increase employment in the country? Many state governments have said that they could only pay the labour union sanctioned minimum wage by retrenching more workers; this means that only those workers who remained in the employment of government would enjoy the rise.

To explain the natural movements in wage in Nigeria, one has to go back to the relationship between Demand and supply of labour. In an environment where supply of labour is higher than the demands, wage in such situation will be lower than where there is high demand for workers. This is the situation in Nigeria. Nigerians need job creation first, then wage increase. I hope both 
the government and the labour unions will come to realize this and do what is needed of them instead of the "do me, I do you" situation that obtain today, where government for fear of opposition do what labour demands instead of what the country demand of her. Just like the Nigeria political system and politicians need to be freed from corruption, unionism and Nigerian workers also need the same deliverance from corruption. Nigerian workers had history of colluding with politicians to enrich themselves at the expense of Nigeria. The extent of unemployment in Nigeria economy require collective effort by both government, private sector and labour unions in order to be subdued to the lowest level possible. While Nigerian government treated labour with some level of fairness, the same cannot be said of Nigerian private sector employers. They operated some of the most unjust employment contract in Africa. Most Nigerian private sector companies have prohibited unionism, they fired employee at the slightest mistake, operated subjective method of promotion, and fight any attempt at demanding for wage increases by their workers. Hence, the reason why many Nigerian graduates did not want to stay longer than necessary in the employment of the private sector. The single fear of lack of security of their jobs in the employment of companies made potential employees to shy away from the private sector. While wages in the private sector organisations such as bank was higher than what public sector paid, manufacturers paid wages that were lower than what public sector pay. In the public sector, Nigerian teachers were some of the most least paid public sector workers. This had tended to affect the productivity of Nigerian teachers, from there to the quality of graduate produced by Nigerian schools.

In 2016, Nigerian inflation rate had hovered around $16.5 \%$ the highest in recent time and 8th highest in Africa. Earlier analysis from Trading Economics, had forecast inflation for that year to reach $18.20 \%$ by end of fourth quarter. Looking at the trend since then, inflation has increased month-after-month, before starting to slow down by 2017. Looking at the condition of the economy, the improvement being recorded in macroeconomic fundamentals, the growing reserve of foreign exchange, investors shall worry less about the near future. Inflation as most of us are aware of is bad for business, and politician facing election shall be wary of it too. Around the world, Nigeria has not been alone in this, most oil producing nations are passing through the same situation. The scenario was a result of two years of decline in oil price, these nations main source of foreign earning - causing shortfalls in government budgets. But in the developed economies of the world, inflation was not a major concern to policy makers. Developed economies have been operating with inflation rate of around $1.5 \%$ over many years. If not for recent events, the main concern in the rich world was deflation. Numerous factors were to blame for the high inflation rate in Nigeria, and not least is interest rate which had negatively affected the inflation rate. The CBN motive for increasing interest rate in the recent past was mainly to protect the value of Naira against Dollar and boost banking sector performance. In economic parlance we knew that Central banks increased interest rate when they wanted to attract savers (not only from within the country but from abroad as well), that in return boosted domestic currency as demand for it by investors increased. This mostly concern foreign exchange fundamentals and how inflation was related to it. As a matter of fact, for a country like Nigeria 
that was import-depended, inflation could be imported into Nigeria, when there were inflations in Nigeria major trading partners' economies. It could also result from high cost of foreign exchange as Nigeria has been experiencing for some years now.

The CBN management has been under intense pressure to find an end to Nigeria's foreign exchange crisis. Thus, adding inflation to the fire would make the CBN case worst. As government borrow to finance its budgets, inflation proved difficult to control. Everywhere around the world, deficit budgeting is inflationary. The rising cost of food items, hike in fuel price and bottlenecks in the supply of other widely use commodities were to blame for the inflation in Nigeria. As most analysts expected, the later liberalization of Naira in the foreign exchange market had link to inflation, at least in the short to medium term. According to an IMF study by Nguyen, Dridi, Unsal and Williams (2015), in the last 25 years, the main drivers of inflation in Africa had been domestic supply shocks and shocks to exchange rate and monetary variables. The study also observes that, in recent years, the contribution of these shocks to inflation has fallen; "domestic demand pressures as well as global shocks, and particularly shocks to output, however, have played a larger role in driving inflation over the last decade". Many previous empirical works have shown negative relationship between inflation and economic growth (Chimobi, 2010; Doguwa, 2013; Idih and Olu, 2015). This was particularly true in case of double digit inflation that ravaged most developing nations like Nigeria. Nigeria rate of economic growth have declined in 2016, at the same time inflation was rising. Hence, the negative relationship between the two major economic variables. Though, there have been much debate among academicians on the actual threshold from where negative relationship between inflation and economic growth set in, most studies agreed that inflation is harmful to growth. As Nigerian government tried to understand the Nigerian economy, we should not expect a quick end to inflationary condition.

Nigerian government has been introducing too many changes at once, some of which were not welcomed by the Nigerian private sector actors, who move (discretely) to undermine these new reforms. Government economic team itself was not quite aware of how to quickly find an end to the inflationary condition. One can safely say that some of the recent economic team members serving the federal government were learning on the job. As a recent IMF study of inflation across Sub Saharan Africa succinctly observes, "country characteristics matter-the extent of oil and food imports, vulnerability to weather shocks, economic importance of agriculture, trade openness and policy regime, among others, help in explaining the role of shocks" (Nguyen, Dridi, Unsal and Williams, 2015). Thus, Nigeria war against inflation was just starting. In addition, when leaders fight corruption, corruption too fight back; those persistent bottlenecks in key areas of the economy experienced between 2015 to 2018 might be connected to this fact. Thus, there was possible link between the persistence inflation experienced in Nigerian and predominance of corruption. Buhari war against corruption if persuade diligently would do a lot of good to his government aim of maintaining single digit inflation rate. The general absence of quality infrastructures had helped in exasperating the inflation menace. This is because lack of good roads, railway lines, power supply, and good sea ports made producers of goods and services to increase the price of their outputs in order to be able to make profits. 
The war against Boko Haram had its own inflationary side, generally when there is war price of goods and service tend to go high. Hence, the recent continued fall in inflation rate can be liked to successes achieved in fighting Boko Haram, increased in government allocation to building of modern infrastructures, self-dependence in the production of food and gradual increase in Nigerian foreign reserve.

Economics, sometimes called dismal science, has tradeoffs (choice between contrasting alternatives) where you were told you could have one but you could not have the other or rather the two at the same time. Examples of tradeoffs abound in conventional economics: inflation and unemployment, the price of bond and interest rate, higher price and lower demands and so on and so forth, but a prominent tradeoff is between efficiency and inequality. Conventional economists believed that one could not start with a situation of efficiency and equality and maintain the two at the same time. This is to say you could decide to have efficiency and forget equality for that duration of time or vice versa. Efficiency meant increase productivity, output, profits and economic growth, while equality means reduction in the gap between the rich and poor, increase in welfare and reduction in poverty. Controversy about subsidy withdrawal is example of tradeoff. Where government wanted to remove oil subsidy for efficiency reasons while citizens were kicking against it for equity and welfare reasons. It is believed that the billions of Naira federal government had spent annually to subsidize price of oil was a waste of money that was not going to the targeted groups. There were evidences that major beneficiaries of oil subsidy were oil importers, distributors, and filling stations across Nigeria. Those who shared this view believed that subsidy was only helping to keep the cartel of oil importers and smugglers in the lucrative market of oil business. Smugglers from Nigeria and their associates from across the border in Niger, Cameroon and Togo had frustrated efforts by Nigerian authorities to supply cheap and abundant oil to its people by smuggling the cheaper oil stock to neighboring countries where price was high.

Points put forward for removal of subsidy included the argument that for Nigeria to have private refineries price of oil must increase. The same point was advanced at the start of power sector privatisation. This it was argued was the only way a private refining business could break even and become sustainable. Staunch advocates of this line of thought believed that increasing the price of fuel was inevitable. Because in order to attain efficient level of oil production locally, domestic price must converge towards international price or that of the neighbouring countries. One other argument looked at the issue from the direction of government fiscal position. Looking at precarious position of government revenue and expenditure, it was argued that it was not wise to continue pumping over two trillion Naira annually to subsidizing oil consumption. It has been argued that these trillions of Naira should have been spent in developing infrastructures in power, transport, health, and education sectors. The above points notwithstanding, lump-sum increase in price of oil in a developing nation contrary to incremental increase carried out over time was unwise and would make things difficult for the poor. To increase price of oil by over $200 \%$ at once would make life difficult for the average Nigerian. A $25 \%$ to $50 \%$ increment was better, to be implemented at intervals. This should continue until price was reasonable to allow 
private refining; but, not high to hurt welfare of Nigerians. For efficiency in the oil sector, government must fight corruption, bureaucracy and red tape.

There are theoretical and empirical evidences that point to relationship between austerity in economic stagnation and social division in instability. For example, in Latin America over the period of their implementations of austerity measures, cases of violent protests, strikes, and attempted revolutions became common. The same happened in Indonesia, especially, towards the end of Suharto regime, with IMF demand to introduce tough economic cuts. Due to nationwide strikes, Suharto had to vacate power. Even in Europe, violent protests and revolts were recorded during periods of economic stagnation. Unlike in Ghana or Cameroon, incidence of poverty in Nigeria was high, this together with unemployment made Nigeria unsuitable for this kind of fuel price increase. Growth undermining existing social institutions as a result of increase in inequality, leads to instability. In order for Nigerian government to reduce wastage and control the amount of money going to the domestic economy, sovereign wealth fund was introduced by president Jonathan. Sovereign wealth fund is a modern answer to wastage and spendthrift. The idea behind SWF, a term that come to global prominence beginning from 2005, though such type of fund exist since 1950s, is that countries shall save excess that accrue during period of abundance against period when government coffers dried. SWF money is invested in different types of assets such as equities, bonds, real estates, Gold and other financial instruments with intention of maximizing returns and minimizing risks. SWF is established for many reasons prominent include, savings, stabilization, economic planning. History of resources rich nations is replete with episodes of wastages and poor savings. Nigeria oil surplus in the seventies was depleted by military government of the time. Government spending in Gowon time and subsequent governments was to blame. Gowon government was quoted to have said 'Nigeria problem is not money but how to spend the money'. The simple meaning of saving in economic parlance, is sacrifice individuals or nations make on their current consumption for future consumption. But, the same Jonathan government that introduced the fund later abused it through excessive withdrawal, despite the billions of dollars his government earned from exporting crude oil. 


\section{MONEY, BANKING AND FINANCE}

\section{Central Banking:}

The frequent shocks Nigerian economy received both from within the economy and from outside has made the existence of strong and viable central bank a must for Nigeria. The role CBN played between 2008 to 2012 in saving Nigerian economy from the financial crisis that hit it cannot be over emphasized. Since its establishment, CBN have created charismatic image in the minds of Nigerians. This must be maintained at all time for the sake of macroeconomic stability of Nigerian economy and achievement of rapid economic growth and development. Thus, heads of Nigerian government must ensure they appoint competent individual as CBN governor. Individual with good background in macro and monetary economics as well as good knowledge of the operation of Nigerian banking system. Appointment base on political considerations or nepotism will undermine the work of the apex bank. Hence, the necessity of making appointment base on merit. The size of Nigerian economy made CBN the most important central bank in sub Saharan Africa only to be rivaled by its counterpart in South Africa. Thus, as Nigerian economy matured global attention will turn to CBN, particularly on issues related to sub Saharan Africa. Nigerian central bank was modelled after the Bank of England and still shared many functions. For example, both of them have been relieved off the responsibility of managing government debt. The responsibility is now with a separate institution called Debt management office (DMO). Both have monetary policy committees responsible for setting interest rate. The composition of the committee is also very similar, including CBN governors, two deputies, members appointed by $\mathrm{CBN}$ and outside economic experts.

Nigerian central bank was in theory independent, but since the start of the presume independence of the apex bank it has never been free from political interferences. Monetary independence in a developing nation like Nigeria would be difficult to achieve. Even the institutions of media, legislative and judiciary are not independent not to talk of CBN that everyone sees as a branch of the executive. Under the Nigerian constitution the appointment of CBN governor is prerogative of the President of Nigeria who after selecting the new governor is mandated to send the name of the candidate to the national assembly for confirmation. The president also appoints members of monetary policy committee, deputy governors and nonexecutive directors. Argument put forward in favour of independent central bank included the fact that central bank would fight inflation better when its decisions are not betted by politicians 
in power. Politicians facing election are only concern with short term goals, unmindful of long term projections. Argument against independence included the point that an important institution like central bank must be accountable to someone. And, that someone is no other than the president or parliament. Around the world empirical evidences have supported case for independent central bank as contributing to macroeconomic stability (Mishkin, 2013). The fact that most developing countries financial system are underdeveloped will act as major hindrance to complete independence of central bank in term of setting monetary policy.

It was in the year 2003 that Professor Charles Soludo assumed the governorship of central Bank of Nigeria. He came full of energy and confidence believing he was the man for the job, one genius that would transformed Nigerian banking landscape. Other analysts believed the same on his prospect of turning things around. His predecessor in that job Joseph Sanusi was slow and conservative, something of the old school, when compare to Soludo's academic background and revolutionary neoclassical economics ideas. Soludo was an economic adviser to then President Obasanjo before being nominated for the top CBN job. As economic adviser he was credited with formulating NEEDS (National Economic Empowerment and Development Strategy) among other things. One policy Soludo is frequently associated with is banking sector consolidation. During the banking consolidation Nigerian banks were rushed into increasing capital base. But, CBN did not give much thought to the effect this rushed process would have on Nigerian banking landscape, particularly its effects on Banking stability and customers' confidence. During the process the number of Nigerian banks reduced from $80+$ to 24 , unprecedented in the history of Nigerian banking sector. The 24 banks were as well rushed into boosting capital base and total deposit. But, the ability of these banks to control and manage the risks they were building up as they increased deposits and liabilities were weakened. Prior alerts and warnings from knowledgeable observers of the industry were ignored by CBN. Sanusi came to the job with a background as a commercial banker. Though, he started in academia but it was for a short period of time, unlike Soludo who reached the level of professorship. Sanusi background as professional risk manager helped him in dealing with the rots left behind after banking consolidation and the financial crisis. Sanusi did a good work in cleaning the sector, albeit, controversially. For example, he fired the heads of about eight banks and jailed some of them. He came out with list of major bank debtors, that included who's who of business and politics in Nigeria. He threatened them with jail terms but back off later. Up to now some of these chronic bank debtors are walking Nigerian streets free.

The Nigerian banking landscape has changed from Soludo's period characterized by rapid changes in banking regulatory environment to Sanusi's era of costly restoration of stability using public funds. Unlike, the universal banking system we had during Soludo, Sanusi reverted the industry to Pre-Soludo period, putting a line between commercial and merchant banking. But, both of them were talkative, controversial and unpredictable figures not like the slow phase Joseph Sanusi who served as central bank governor before Soludo. Both, people came to the job relatively younger than some of their predecessors who held the job before them. While Sanusi felt he was aristocratic, Soludo cut the image of an academic central banker - a genius (remember 
his boasting, 'I am an Econometrician, macro-monetary economist and development economist', blah! Blah!!). The case of Soludo and Sanusi can be compared to Alan Greenspan and Ben Bernanke their respective counterparts as chairmen (governors) of Federal Reserve (US central bank). Just like Soludo, Bernanke spent most of his career, before his appointment as Federal Reserve chairman, teaching in university as professor of economics. While like Sanusi, Greenspan spent most of his working live outside of the university world dealing with the real world as consultant. Because both Sanusi and his successor on the job (Godwin Emeifele) came from a commercial banking career, they were more effective and gradual in monitoring and introducing changes to the banking environment. But, because Soludo had no such experience he favour experimenting with theories with the view to find their effectiveness. This led to the introduction of his highly controversial banking sector consolidation. Sanusi background in risks management helped him in clearing the mess left by Soludo consolidation after financial crisis hit Nigerian banking industry. The financial crisis of 2008-2009 happened under the chairmanship of Bernanke at Federal reserve and Soludo at CBN, who were both university professors. Soludo introduction of revolutionary changes in the system made it difficult for a developing country financial system to handle such a change within so short a period of time.

\section{Commercial banking:}

It was Charles Soludo, the architect of Banking sector consolidation, who championed the creation of mega banks in the Nigerian Banking landscape. The idea behind consolidation is to create 'too big to fail' banks with larger capital to support economic development. But, what we later have were banks that were too complicated and lack efficiency. Instead of using their capital to support development they ended up supporting share buybacks and speculative investment of oil marketers. Instead of banks to rely less on public funds, due to their bigger capital base, they turned financial monsters that depend on easy to get public money without paying equal return to the government treasury. By the time Soludo left CBN, Nigerian banks have return to the business as usual state they were before the consolidation with the exception being that they were now very big in size with huge loads of nonperforming loans, the results of these banks wasted credit creation process and thieving CEOs. When the global financial crisis reached Nigerian banking landscape, Nigerian banks were left in state of near bankruptcy with few already bankrupt. This came despite Soludo assurance that Nigerian banks would not be affected during crisis. As a result of the bad debt of banks that resulted from the bad state of Nigerian banks, CBN established the Assets Management Corporation of Nigeria (AMCON). AMCON itself absorbed some N5.7 trillion of toxic assets in the aftermath of the banking crisis of 2009. A report on the banking sector show that five banks lost some N54 billion from their 2014/15 financial year. There was sharp increase in nonperforming loans in the banking industry as CBN report showed an increase of $78.8 \%$ in the year 2015, a staggering figure of N649.63bn. Between April 2015 to April 2016 the banking industry recorded a decline of N154bn in its total assets, while gross credit to both public and private sectors declined by 0.3 percent. There was also sharp 
increase in $\mathrm{CBN}$ loans to the banking industry which indicated that Nigerian banks were relying more on $\mathrm{CBN}$ to meet their day to day obligations and that banks were unwilling to lend to each other. The total toxic assets that were absorbed by AMCON was N5.7trillion.

The level of innovation in the Nigerian banking industry was low compare to what obtain elsewhere, even for the little innovation presence at the time it was done by few banks in the forefront of the banking revolution. We can see the result of it in term of operational efficiency of these banks. For detail essays on innovation and efficiency in the banking industry consulted some of the works listed in the bibliography section. Due to weak revenue many Nigerian banks had witnessed declining profit during the first quarter of 2016, hence the desperate moves by banks to cut cost through retrenchment of their workforce. The major blow to the Nigerian banks is government Treasury Single Account (TSA) policy which has deprived banks of the main source of their cheap funds and send them in other directions looking for funds. According to estimates, the TSA mopped in an excess of N1 trillion from the banking system back to the Central Bank of Nigeria. The decline in the price of crude oil in the international market also hit the banks hard, as they have issued loans to major oil marketers in the sector and the fact that lower oil price lead to cash crunch in the economy. With the introduction of the flexible foreign exchange policy, foreign investors were expected to return to the Nigerian market which would positively affect the performance of the banking industry. Banking stocks have witnessed increases on the first days of the introduction of the flexible exchange rate, performing better than the NSE all shares index. In 2016, Nigerian banks according IMF Chief were in better shape than during the last global financial crisis. There were huge opportunities in other sectors of the economy that banks were neglecting to invest in such as agriculture, and infrastructures which were the focus of the Buhari administration economic transformation agenda. Nigerian economy was hugely under bank which meant that there was huge opportunity for grow in the industry. The Bank Verification Number (BVN) system has revolutionized the banking business in Nigeria, it has cut bureaucracy and reduce corruption as well as opened the retail sector. It would indeed help the grow of consumer credit in the banking industry. Nigerian banks were not efficient, considering the opportunities available they failed to utilize and the wastage in the system.

June 23rd 2016 will be remembered as the day UK vote to leave the EU bloc. The financial industry around the world was shocked by this single outcome of a referendum undertaken in 2016. Banks share prices fall on the announcement of the final result of the referendum. The London stock market was also affected. But, things remain as it were for at least two years when the UK formally exit from the bloc. The Nigerian economic sector that would be most affected is the banking sector where Nigerian banks were highly correlated with London based international banks who were planning to move some of their businesses over to other EU member nations. Nigerians banks have set up offices in the UK just because of its strategic importance in the EU. After full Brexit Nigerian banks would reconsidered their position. Nigerian Central bank financial dealings with London base banks would also be affected, be it in form of foreign exchange dealings or its foreign reserve savings there. It is a difficult moment for Nigerian banks at a time when they were recovering from past financial crisis, facing recession and deterioration in foreign 
exchange, Brexit temporarily added to their difficult situation. Thus, clever banks had already put contingency plans to address the outcome of the Britain move out of the European Union. Nigerian companies that were planning to sell their shares on London stock exchange through initial public offering had to reconsider their next actions in view of realities on the ground. Investments by Nigerians in the UK would also be affected due to possible repercussions from the Brexit deal. There were desperate moves to diversify investments out of the UK. Many Nigerian real estate investors found London less attractive and start to make moves to sell their holdings there. But, Nigerian investors holding Gold had smiled to the banks as the price of gold temporarily increased around the world. The same applied to Nigerian banks holding gold reserves. Then came Nigerian elites looking for safe haven for their ill-gotten wealth, Britain out of EU might be perfectly OK with that, as it might help cover losses from exiting the EU. British government looks to common wealth countries such as Nigeria for closer economic relation after Britain left the EU. This will offer different opportunity for Nigerian banks.

\section{Banking reform}

History of banking reform in Nigeria goes as far back as 1960s. It did not start with Sanusi Lamido Sanusi or Charles Soludo. In the late eighties, there was the liberalization of banking sector, helping the emergence of the so-called 'new generation banks'. That reform program led to subsequent collapse of many of these newly registered banks, with thousands of Nigerian depositors losing money. The aim of the reform of making finance accessible to most Nigerians was not realized for reasons that included lack of coordination, politics, corruption and absence of enabling environment. In the nineteen seventies, there was the nationalization of foreign own banks by federal military government to help ushered in local control of these banks, development of local expertise, as well as linking the banking sector with wider government economic goals. But, Charles Soludo banking sector consolidation had emphasized growth over security of assets, creation of mega banks over micro financing or increase access to credit by productive sectors of the economy. His revolutionary increase of banks' capital base from two and half billions to twenty-five billion Naira (with intention of increasing banks strength, making them less susceptible to capital erosion) had created news headlines making banks buried in race with one another. But, in fairness to him he has increased the global reach of Nigerian banks putting them among the biggest banks in Africa. Reforms in period of social and economic changes were less open to resistance compared to those undertaken in total contradiction with their environment. Sanusi banking reforms were widely accepted outside Nigeria, coming after the global financial crisis of 2008. Many observers wonder how he could achieve his stated aims looking at the rots in the banking system. Injection of government money in form of liquidity support into sick banks led to Central bank prompting up of these banks with up to four billion Dollars of public money. Sanusi reform dismantled universal banking replacing it with commercial and specialize banking model. Specialize banks include agricultural and industrial banks, primary mortgage banks and non interest banks. The reform program categorized banks' capital base 
according to the sector bank operate and geographical spread of its branches. Bank CEOs (chief executive officers) tenure was fixed at five years. An asset Management Company was established to buy bank's toxic assets.

Asset Management Corporation of Nigeria (AMCON), a toxic assets handling company, was established in 2010 to help rescue Nigerian financial system from total collapse, after financial crisis nearly brought Nigerian economy to a halt. According to its management, AMCON was created to be "a key stabilizing and re-vitalizing tool established to revive the financial system by efficiently resolving the non-performing loan assets of the banks in the Nigerian economy". Whether the institution has achieved that is debatable. In the past, activities of AMCON had come under political interferences. Just like EFCC, AMCON was used as hunting tool for political rivals with debt up their necks. But, a decade after the crisis, the continued operation of AMCON might only spur up next round of financial crisis. Since it guarantees buildup of bad loans by banks who have an assume assurance of Nigerian government coming to their aid through AMCON. Like the IMF has observed, it continues operation may " wittingly and unwittingly increase instances of moral hazards and fiscal risks". It existence maintain the memory of 2008/09 crisis on mind of Nigerian public which itself is not good for business. In previous crises, the Asian financial crisis of 1997/98 had devastated the South East Asian economies. One of the measures taken by these economies to get their financial systems out of the crisis was creation of asset management companies, just like in Nigeria. In Indonesia IBRA (Indonesian Bank Restructuring Agency) was created in January 1998 to protect and restructure the country's banking system within a fiveyear period. One of its successes was the rapid assets disposal in order to return assets to the real economy where it belongs. Money recovered by IBRA was channeled into quick resolution of Indonesia's huge budget deficit. How far did AMCON succeeded in channeling recovered money into government budget is not known? Thai Assets Management Company (TAMC) of Thailand was established on June 8th 2000 as a state agency tasked with responsibilities of restructuring business and returning debtors' business back to profitability. Although, TAMC has a time period longer than five years to wind down its functions there were clauses inserted in the policy documents establishing it that urged it to quickly bring it operations to end. In Malaysia, another South East Asian country, Malaysian Asset Management Corporation was created in June 1998 to remove non-performing assets from the economy and manage them. It also has finite lifetime of five years to wind down it functions, at the end of it mandate in 2005 MAMC had performed reasonably well.

When an investment model is doing well no one ask questions, until late when cracks appeared in a supposed smooth financial engineering genius. Margin lending for banks' own shares accusation allowed by Central bank of Nigeria on the binge of 2009 crisis caused the booming trade in the Nigerian capital market observed at the time. What was then required to get loan from Nigerian banks for purchase of shares was small percentage of the entire share purchase money. Banks provided remaining 80 to 70 percent of the money for transactions in their shares. Nigerians, including banks' staffs, were lured into buying shares irrespective of performance of stocks in term of profitability and growth. This, temporarily, helped the 
performance of these banks on the stock exchange. When the market finally collapsed, people were left with junk certificates. Managing directors of these banks had used their privileged knowledge of the stock to quickly sell their own shares before the collapsed. Another dimension to the crisis was speculative activities by importers of refine petroleum products. Banks executives colluded with oil importers to trade in oil related derivatives in order to make quick gains. Banks most exposed to these businesses later collapsed. These loans were granted on flimsy investment grounds. Greed has made bankers no better than laymen with no background in finance. Price of crude oil had reached climax, near $\$ 150$ per barrel. Booming demand for energy led by high consumption in China and India contributed to the energy crisis. But, Chinese economy had already over heated. Chinese economic managers were desperately searching for a break to their economy high growth path that caused the high consumption of raw materials. Finally, when the speculative money coming to the Nigerian oil sector from global financial centers reduced, price of crude oil plummeted.

Moneys generated through bank's traditional deposit sourcing were channeled into speculative activities, satisfying the hunger of top executives and shareholders for quick gain. Modern bankers are vultures looking for dead meat (clients' money) to feed on. Banks have turned our nations into spendthrift societies by means such as consumer credit. Nigerian banks had financed anything from purchase of car, home appliances, holidays, to election rigging. Thus, banks instead of encouraging saving habit killed it. Nigerian banks' balance sheets have not translated into investable funds needed to finance Nigeria's economic development. Compare our banking system with other economies, in china government made sure finance was channel to strategic sectors of its economy. These are building of infrastructures, construction of power generating plants including nuclear reactors, development of manufacturing and micro credit system. India, Brazil, Indonesia, and Turkey followed similar pattern. Because of this, there should be a special tax in the Nigerian financial sector. This is for encouragement of developmental finance. Imposition of tax on speculative and highly risky banks assets freed money to productive activities needed for rapid industrialization. Financial Institutions like Bank of industry (BOI), Nigerian agricultural cooperative rural development bank (NACRDB), Urban development bank of Nigeria, (UDBN) and National economic reconstruction fund (NERFUND) have been pushed to the periphery of the system. Past banking reforms have focused on commercial banks neglecting development finance institutions. Economic development cannot be realized without these institutions. Commercial banks and other profit oriented finance institutions are short-termists, while development finance institutions are long-termists. The processes involve in economic development are long term, hence, the need for these banks. Commercial banks spearheaded economic growth only where profit is to be realized.

Sanusi Lamido had introduced reforms that led to transformation of Nigerian banking landscape. At the period he assumed duty as governor of CBN, Nigerian banking sector was passing through the devastating impacts of the last global financial crisis that left Nigerian financial sector in coma. There was wide spread fear that major Nigerian banks were facing threat of collapse with repercussions for Nigerian economy. This left Sanusi with difficulties concerning 
alternatives to choose from, should he allowed these banks to collapse (about eight of them) or should he instead allowed government (CBN) to rescue them? He took the last alternative by providing government rescue lifeline. But, before that he had sacked the managing directors of affected banks, who people blamed for the situations in their banks. Sanusi later introduced corporate governance reforms that included limiting of bank's MDs tenure to only two terms of five years, Central banks screening of new directors of banks, bringing an end to the culture of family own banks, banning former CBN governors from holding strategic positions in banks until long after they have left office, and a new executive succession guideline. Other reforms introduced by Sanusi includes, uniform financial year ending, replacing of universal banking model with differentiated banking model that allowed for establishment of specialized banks including Islamic banks, establishment of asset management company of Nigeria (AMCON) to buy toxic assets from Nigeria's banks, new rules on end of year results publication, cashless economy road map, curtailing banks' lending to capital market, establishment of credit bureaus among others. CBN intervention of 2009 was hailed as the only banking intervention that ordinary depositors did not lose money.

\section{Behaviour of Conventional Vs Islamic banks during crisis}

The financial crisis of 2008 has exposed some of the weakness in the global banking system. The crisis began in august 2007, after defaults on subprime mortgage loans in the US. But, with financial Tsunamis hitting the world main financial centres, the much acclaimed triumph of capitalist banking system was put to test. The crisis had been characterized as the worst financial crisis since the great depression. During the height of the crisis financial power houses have gone under. The investment giant Lehman Brothers had to file for bankruptcy protection from the US authorities. The then world biggest insurance group AIG was deflated to such an extent that US government was left with no alternative but to dole out a whopping \$85 Billion of tax payers' money as a bail out. This was done to avoid loss of confidence in the financial system that could lead to run on other financial institutions. While price of shares traded on the world's major stock exchanges collapsed. This happened ten years after one of the most devastating financial Tsunami hit Asian economies. In what is today term 'Asian financial crisis', whose impact stayed with the Asian economy for decades. Signs of that imbroglio started to manifest years before. Four years before the global financial crisis, financial indicators had shown the boom in the US housing Market had reached saturation level, but banks continued to doll out depositors' money to Mortgage financing. Regulators on their part kept a blind eye. There was debate then on whether central bank [The Fed] should regulate asset price inflation, or should restricted itself to conventional inflation i.e. consumer price inflation. Alan Greenspan, the then chairman of the Federal Reserve and his team, were buried in his now famous 'Irrational exuberance', to lend a listening ear to call for a brake on the other Exuberances in the housing market. When the market finally busted, banks were left with valueless papers as collateral against their billions of Dollar worth of loans. 
The US and UK major advocates of shareholder capitalism were most hit by the crisis. A Year before the crisis peak, the British Bank Northern Rock was forced to declare bankruptcy, in what observers Saw as aftermath of excessive exposure in mortgage lending. Thus started the beginning of a serious housing market crisis. To stop it from spreading, in April of 2008 the bank of England had to lunch the special liquidity scheme of $\$ 100$ Billion in an attempt to arrest the problem. A costly rescue with tax payers' money. As one financial analyst had rightly observed, in capitalism profits are private affairs, while risk like the doom on the world economy caused by the crisis, are social matters, to be settle with tax payers' money. In the US, in March of 2008, US government had to lunch a rescue plan for Bear Stern, another actor in the financial market. And, in July of the same year, another giant Indy Mac Bancorp, a Californian thrift was taken over by regulators, to avoid a contagion. In midst of the Bear Stern crisis, the Fed in a desperate attempt to show the public they were on top of their job, injected \$200 Billion term securities lending facility into the economy, but with little to show thereafter. Bank of England adopted the same method the following month, when it lunched the special liquidity scheme. Fed rescue plan notwithstanding, the two biggest mortgage institution in the US Fannie Mac and Freddie Mac were swept away in that financial hurricane. In July 2008, the American treasury led another emergency rescue plan to save them. The twin's giant owed or Guaranteed outstanding mortgage worth some $\$ 5.2$ Trillion. The European banks, UBS and Credit Suisse were affected, in the same way, by the crisis. UBS wrote down bad loan worth $\$ 38$ Billion.

One thing that was clear all through the crisis, is the intensity of the crisis in UK and US compare to other developed countries like France, Germany, Holland, Denmark and Finland. One of the many explanations for this is that their economies were not controlled by the kind of greedy unethical capitalist found in the Anglo-Saxon countries. The European countries mentioned, were advocate of the soft capitalism; in which, though private sector was the major actor, government did intervene to guide economic activities. But even in the US, there was an intense debate on whether government should actively regulate economic activities. The Democrats favour regulation, while most Republicans were in favour of deregulating the Economy. This was not new, for years there had been serious debates between the neo-liberal economists who called for sidelining government from economic activities and the neoKeynesians and their offshoots who supported government participation. Some overzealous advocates of deregulation even called for abolition of central bank and with it central banking all together. To me this is not realizable in the current era. It was the deregulation of the financial market in Asia in the 80s and 90s that caused the Asian financial crisis I made mentioned of. The world should not forget how Russia burnt it fingers in 1998, when it tried to experiment with deregulation. There was also the Mexican financial crisis of 1994.Those countries that went contrary to deregulation dogma, during the Asian crisis, fared better than those that followed, religiously, the IMF/WORLD Bank prescriptions to deregulate their economies. Instead of leaving her economy at the Mercy of speculators, China introduced heavy capital control measures and pegs her currency to the Dollar. At the end of the crisis, it was China that rejected the Britton 
wood institutions Tsunamic advice that escaped the crisis. Malaysia quickly adopted the same method to save herself from falling into the same trap as Indonesia and Thailand.

Trillion Dollars of tax payers' money have been lost to financial crisis around the world, over the years. Despite that, some greedy individual speculators still called on government to allow individual capitalists to do as they like; to be their own regulators. How does one expect a hungry salivating Tiger to control herself away from attacking it prey? Many studies have shown the devastating impact of financial crisis on economic growth. It had been demonstrated, how financial crisis washed away years of hard earn economic growth. These should have acted as lessons to our policy makers, but because they have their own interest to protect, they never care. The great depression of 1930s was caused by government inability to control the haste and greed of investors. The same crops of ruthless investors were at work nearly a century later. The banking crisis that occurred in Nigeria between late eighties to middle of nineties was a result of liberalization of the Nigerian banking industry by military regime of Ibrahim Babangida. The result of that led to the collapse of hundreds of Nigerian banks and loss of deposits by some of these banks clients. The military government of Gen. Sani Abacha set up fail banks tribunal in order to settle disputes that erupted after the collapse of too many banks. Thus, while introduction of new products (financial engineering) was the genesis of global financial crisis of 2008, liberalization of Nigerian banking sector caused Nigerian banking crisis of the early nineteen nineties. The financial liberalization that led to the banking failure in Nigeria in the 1990s had led to credit boom, but so did the banking sector consolidation introduced by Soludo. The consolidation of 2004 led to huge credit boom that was later followed by banking crisis.

Islamic banks have performed better during the crisis compared to conventional banks. Islamic banking system is built to avoid some of the shortcomings and loopholes of the conventional banking system. The major point of departure between conventional and Islamic bank is on interest charging accepted in conventional banking but rejected by Islamic banking. Islamic banking has so far survived for over forty years, despite pessimism of those who initially saw it as a fail project and not sustainable. Today there are hundreds of Islamic Banks spread all around the world, that are operating according to Islamic business contracts. Recognition of the system has come from major western institutions such as the World Bank, International Monetary Fund, investment banks like Goldman Sachs, universities such as Harvard University, Oxford, Cambridge, just to mention a few. There is over $\$ 2$ trillion under Islamic finance management with the system growing at double digit rate over the last three decades. Islamic banking system was tested during the global financial crisis of 2008 when the foundation of global financial system was shaken. Banks such as US Lehman Brothers and Wachovia, were wiped out of the banking landscape. In Nigeria, banks like Intercontinental bank, Oceanic bank, Bank PHB were declared insolvent and sold to new owners or taken over by federal government. Banks that remained after the crisis were left with bigger holes in their balance sheets to the extent that governments around the world had to intervene to serve them. Trillions Dollars of Tax Payers money were spent in bailing out those banks from a financial injury that was clearly self-inflicting. According to many commentators the major causes of the crisis were the accumulated interest- 
dominated debt, greed inherent in the system, speculative investment, lax regulation on the part of central banks and absence of a moral restrainer.

The Economist of London (Sep 7th 2013) referred to the causes of the global financial crisis, thus: "The most obvious is the financiers themselves-especially the irrationally exuberant Anglo-Saxon sort, who claimed to have found a way to banish risk when in fact they had simply lost track of it." Then there was reckless financial engineering, where all kind of financial products were developed and put into the market without regulators doing the thorough assessment of the products expected of them. This go contrary to what obtained in the sciences, where before a new discovery (product or system) was put to public use, they must have undergone thorough test to determine applicability, durability and potential harm to people and environment. In the US, financial engineers turned highly risky mortgages into (theoretically) low risk products and sold same to the naive public - the subprime lending debacles. Products such as credit default swaps that were meant to spread risks concentrated it in fewer places. At the heart of the uniqueness of the Islamic banking system is the prohibition of interest and its replacement with profit and loss sharing. This single act allow flexibility at times of crisis and period of growth, as it act as shock absorber. In period of crisis, depositors and investors share lost/less profit, while at period of growth higher profit is shared. But, in the conventional system, interest rate does not adjust during period of crisis and growth, as it remains fixed in respective of performance of the venture. Islamic banks are restricted on moral ground on where (type of assets) to invest their money. For example, they cannot invest in gambling, highly risky business ventures, speculative activities, prostitution, and other transactions considered to be unethical. Islamic banks are not allowed to put investors' money in the kind of derivatives that accelerated the last global financial crisis.

According to a 2010 study by two IMF staffs (Hasan and Dridi) Islamic banks performed better during the global financial crisis when compared to their conventional counterparts. There are many other studies that found similar results using different methods (Wasiuzzaman and Gunasegavan, 2013; Shafique, et al, 2012). In Nigeria, one of the root causes of the past banking crises, was the highly risky and speculative investments of Nigerian banks, after the Charles Soludo's banking sector consolidation that resulted in Nigerian banks dolling out money to oil importers, as well as loans dedicated to buying unsecured (highly risky) equities on the floor of Nigerian stock exchange. By December 2010, all these loans turned out to be the non-performing loans bought by the government funded Asset Management corporation of Nigeria (AMCON). Today it is a history matter, as we know that the greed, corruption and reckless investment decisions of Nigerian banks managers were responsible for the crisis and its aftermath that left its marks around. Since coming to power of President Buhari in 2015, Nigerian banks have been very careful of the type of transactions they involved themselves with. Nigerian bankers are daily becoming more discipline and ethical. The era of irrational growth and assets accusations seem to be over for now. The federal government's Economic and Financial Crimes Commission (EFCC) has put her radar on Nigerian banks watching over the billions of Dollars transaction they are running. Some banks have been sanctioned by EFCC and CBN due to their irregular transactions, 
conducted in the past. The introduction of treasury single account (TSA) has limited the amount of government money that banks can save in their vaults. TSA has forced banks to move billions of Dollars of federal government money to CBN own vault. The introduction of Biometric Verification Number (BVN) has made it difficult for some category of illegal banking transactions to be conducted. For example, BVN has help exposed hundreds of thousands of ghost salary accounts being used to siphon government money by corrupt government officials.

Official deposit insurance originated from former Czechoslovakia in 1924. But, United States popularized it during great depression's banking crisis of 1933. In Nigeria deposit insurance started in 1988 following SAP implementation that led to the liberalization of Nigerian banking system. With about 25 years of operation, deposit insurance in Nigeria has not changed much. Just like private insurance market, deposit insurance provided by Nigerian Deposit Insurance Corporation (NDIC) has remained underdeveloped. Nigerian private insurance market is shadow of the banking industry. Its public sector equivalent provided by NDIC is not better. Critics of official deposit insurance scheme blame it for causing moral hazard and encouraging banks to take excessive risk, causing the next round of banking crisis. Many Nigerian depositors do not know much about NDIC or her insuring of depositors' money in banks. Wealthy Nigerians with huge interest in the banking system (that are insured by the corporation) are the ones who knows of existence of NDIC. It was not long ago that NDIC unveiled its new identity aiming to 'deepening trust, improving communication with depositors and providing greater protection'. It took NDIC two and half decades to realize it needs to communicate more with the people it is insuring. NDIC has slept under the shadow of CBN. This contradict its mission of strengthen openness and transparency by deposit taking banks. The institution does routine assessment of soundness of Nigerian banks, but in most times as NDIC come out with its ratings, CBN come out with her own to contradict NDIC. Most people do not pay much attention to NDIC ratings, stakeholders care mostly for what CBN says. NDIC lacks the independence and human resources to steer the institution that bears its name with the changes taking place in global banking industry.

\section{Microfinance:}

Empirical investigation by Evbuomwan, Okoruwa and Ikpi (2013) confirmed that credit had a positive effect on gross domestic products (GDP) of Micro, Small and Medium Enterprises (MSMEs) in Nigeria. Small and medium scale enterprises have played unrivaled role in the development of nations around the world by contributing to GDP, government revenue, employment and innovation. In Nigeria, MSMEs accounted for most of the enterprises in agriculture, trade and industries. But, Micro finance in Nigeria is an area Nigerian authorities seem not to care much about. The focus of Nigerian authorities has always been on commercial banks who churns out bulk of their credit to government cronies and powerful businessmen. Apart from agencies such as Central Bank of Nigeria (CBN) who focus on commercial banks, Nigerian media itself is guilty of neglect and failure to turn their pens and cameras on the industry thereby drawing attention of authorities to the sector. Nigerian media were busy romancing with 
big commercial banks who patronized them through placement of advertisements and credit extension. Nigerian public on their part are ignorant of the working of microfinance. Past efforts to establish community banks failed due to insincerity of government, faulty foundation, neglect and absence of regulatory mechanism to control community banks. Today microfinance industry came into being in 2005 after formulation of national microfinance policy by CBN in line with Millennium Development Goals (MDGs). Nigerian authorities were forced by coercion from bodies like the United Nations to support microfinancing as part of MDGs. Unlike in Bangladesh where government and nongovernmental organisations adopted it as a way of solving the country's developmental challenges. This explain the pioneering role played by the Nobel prize winning Bangladeshi economist Muhammad Yunus in establishing Grameen Bank. He helped revolutionize microcredit not only in Bangladesh but worldwide.

In 2011, Muhammad Yunus criticized Nigeria's CBN for not understanding what it is regulating as far as microfinancing is concerned. He faulted Nigerian microfinance sector as not for the poor but for traders and suppliers. He observed that Nigerian microfinance banks were only found in cities and towns but not in villages and other rural communities; and lent base on collateral and not for starting business. He continues that, they were not for women, charged exorbitant interest rate more than what was charged by commercial banks, and were owned by the rich instead of being own by the poor who were its main customers. In short what obtained in Nigeria as microfinance institutions are nothing but 'micro-commercial banks'. These are contrary to what is obtainable in the microfinance industry of Bangladesh where banks go to door step of the poor to provide services instead of the poor coming to them. Yunus advocated the changing of framework from profit oriented microfinance banks to social business aim at reducing poverty. Because of pioneering contributions of development economists like Yunus, Bangladesh is no longer seen as 'Basket case' by the development community. Live expectancy of an average Bangladeshi has increased from the 1970s level and abject poverty has been minimised. Regulatory authorities such as CBN, NDIC, and finance ministry must help in changing the current status of the industry. Federal and state governments must provide business capital to the poor through means like microfinance. Nigerian government provision of social capital to the poor shall be done through existing microfinance institutions. This will help to give them some credibility. Between 2016 to 2018 billion of Naira has been allocated for onward distribution to the poor and unemployed youth. Federal government shall encourage establishment of microfinance banks for its existing social loan programs to succeed. Looking at the Nigerian population and the scarcity of resources, private sector investors shall be encouraged to invest in this line of business. 


\section{CAPITAL MARKET AND FOREIGN INVESTMENT}

Nigerian stock exchange

Stock exchange, the market where equities and bond are traded, monetary worth of companies and governments are determined, and different kind of assets are displayed in their absence, is significantly different from layman understanding of the term market. Unlike ordinary market a stock market is an international market that acts as barometer for measuring the health of an economy. Stock market indexes like New York Dow Jones, Japanese Nikkei, UK FTSE, and Nigerian All Share Index are the first signs economists and investors look unto when they want to measure the overall health of world economy or that of any other country. At the eve of fears about US debt, following the down grading of its bonds, stock indexes everywhere around the world falls signaling investors fear about the US economy and the world economy in general. Stock exchanges have remained key transmitters of globalization process. Stock market functions as meeting point between local entrepreneur-firms and international capital cannot be matched by any other market. Likewise, it ability to satisfy both sides to a transaction- the entrepreneur firm and the international investor- cannot be performed by other markets. Nigerian stock exchange is therefore, one of the two to three windows that linked Nigeria to the globalization process. In this, NSE is more significant than both the Nigerian foreign exchange market and its commodities markets. Since liberalization of Nigerian economy that began in the 1980s, NSE has moved from being a local hub for mostly domestic companies and investors to its current position of being a regional hub for investments coming to sub Saharan Africa. Around 2007/2008, NSE was ranked among the fastest growing stock markets in the world, attracting international investors from as far as Canada and China. In 2017, it was ranked most profitable. In its drive to meet some of the challenges caused by globalization, NSE began computerization of its trading flat forms in the 1990s. This began with introduction of Central Security Clearing System (CSCS) in 1997. It had helped cut transaction days needed to execute a deal, from twenty days to three days. Automated Trading System (ATS), creation of internet connections, and technological linkages were among changes introduced to answer the call of globalization and modern information technology. 
But the challenge of globalisation is more than what is mentioned above. The NSE was yet to meet other critical challenges of globalisation other exchanges around the world were grappling with. The impact of 2008 global economic crisis on NSE had been devastating. In fact, NSE was one of the worst affected by the crisis. Despite recovery, NSE is yet to recover fully to pre-crisis level of transactions volume measured by the all share index. In the past, the exchange was mired in leadership crisis that called it supposed corporate governance mechanisms into question. Many governance questions raised by the past leadership crisis are yet to be answered by the management. The same way NSE required listed companies to abide by corporate governance mechanism, NSE must follow the same rules. Modern exchanges around the world are run as public private companies. International investors are not only looking at the listed companies they are putting their capitals into but also the stock market where the companies are listed. Thus, NSE management must reform the market in line with global practice. A noticeable change in management of stock exchanges around the world in the last one decade is mergers among stock markets. The move though it has faced setbacks in the past, is examples of changes caused by globalisation. Stock market as agent of globalisation had to change itself to conform to reality of globalisation. The biggest stock market in the world, the New York stock exchange is noted for the technology it deploys and its flexibility to changes. Fear of erosion of control among stakeholders has acted as impediment to reform in NSE. Asian financial crisis of 1997/98 has changed Asian stock exchanges forever. NSE shall learn from it and the past global financial crises of 2008.

As one of the three biggest stock markets in Africa, Nigerian stock exchange has been on the radar of foreign investors for so long. The other two, Johannesburg and Cairo exchanges, have regularly featured among emerging markets stock exchanges. The fact that South African economy is more matured than Nigeria's provide explanations behind featuring of Johannesburg exchange among emerging markets stock exchanges. NSE was only later listed among the emerging markets stock exchanges listed by $\mathrm{MSCl}$ (Morgan Stanley Capital International). While Cairo stock exchange is not only hub for rising capital for African firms but more important is its strategic location in the Middle East, provide it with vibrancy. Like most other stock markets around the world, Nigerian stock exchange was devastated by the financial crisis of 2008. Many factors account for slow recovery from the crisis, some of which included management crisis, unethical dealings, bankruptcy of stock broking firms trading on the exchange, financial sector reforms, as well as fear of repeat of losses incurred in financial crisis of 2008-09. Others include bubble created during the peak of 2008 (by margin lending from banks who did so to boost value of their shares) was out of tune with fundamentals of the market. Fake growth in transaction volume and valuation created by the bubble led investors into losses when the market turned sour. Stock exchanges reflect strength of economies in which they are based. For example, technology firms are most capitalized firms on America's exchanges, financial firms in London stock market and mining companies in Johannesburg stock exchange. In Nigeria the most capitalized company listed on the NSE is Dangote group, a conglomerate that produces things from cement, noodles, juice, to sugar, then followed by banks. Because combine capitalization 
of banks on NSE is big, NSE move with the fortune of banking industry. Hence, the slide in the All Shares Index as Nigerian banking sector recover after the crisis of 2008-09. Growth in Nigerian economy and improvement in world economy are other factors that cause grow in Nigerian stock exchange. Rise in international price of crude oil had in the past offset slowdown in the world economy transmitted to Nigerian economy. Thus, price of crude oil has direct and indirect effect on NSE. Inflow of foreign speculative investment into NSE moves with health of Nigeria and global economy.

NSE had issued licenses to its members to act as market makers. This was done to help deepen market and increase liquidity. Appointing reputable institutions as market makers help avoid shenanigans that have tainted image of the exchange in the past. The exchange alone cannot change much if corporate culture and governance mechanisms of listed companies are not strengthen. Many Nigerian companies are a long way from meeting international listing standard, hence, the apparent absence of Nigerian company on big stock exchanges. In some few studies undertaken to measure the relationship between corporate governance and financial performance of some of the listed companies on the exchange, the studies discovered that concentrated share ownership common with the listed companies tend to affect their performance, and that, adaptation of good corporate governance increase firm performance. Depreciation of Naira is bound to affect shares listed on NSE negatively likewise inflation. With inflation, rise in interest rate will cause slide in performance of NSE. The past leadership of the exchange under Ndidi Okereke was accused of orchestrating problems affecting the exchange. It was Okereke who instead of focusing on her job went on a jamboree of rising money for reelection campaigns. At a time, the market was rated the worst performing in the world in 2009.

Looking at the huge losses incurred by investors in Nigerian stock exchange (NSE) after the 2009 financial crisis, many professional investors were asking the important question of whether it was possible to make money by investing in the market. Since 2009 to date, the performance of the market has been moving up and down making the market one of the most volatile in the world. Beta as measure of investment volatility in the market has been high over the period, while profits paid (in form of dividend and capital appreciation) has not been high enough to compensate for the high risk. Considering the current unpredictability of Nigerian foreign exchange management system operated by $\mathrm{CBN}$, how safe is it for a foreign investor to include Nigeria in his portfolio? Added to this is the fact that Buhari's government is yet to have a complete blueprint on ways to manage Nigerian economy in the face of $d$ windling revenue. According to conventional portfolio models, such as Capital Assets Pricing Model (CAPM) developed by Sharpe and other scholars, and Arbitrage pricing theory (APT) developed by Stephen Ross, return to any investment is payment for non-diversifiable risk. And, an investment is good only when it is able to earn an investor reasonable return with minimum risk. Taken the above into consideration, investment in the Nigerian stock exchange will look unattractive to investors. Of course, this is actually what has been happening over the years as the level of investments in the market keep falling. Though, the market has recovered some of its mojo, but it is yet to return to its pre-crisis level. 
Like other African stock exchanges, with the exception of South Africa's, Nigerian stock exchange is segmented from other major stock exchanges in the world. This has important implication, it means that Nigerian stock exchange is good for inclusion in international investment portfolios created by various fund management companies and other global investors - since lack of integration means the market does not move together with the rest of the world markets. Hence, Nigerian stock exchange will be perfect for portfolio investment. But, on the other hand, lack of integration means absence of efficiency and underdevelopment of the market. Here the simple lack of efficiency will among other things means poor service provision, high cost of transactions and bureaucracy. Thus, foreign investors who decided to include the market (i.e. NSE) in their portfolio must be cautious and calculative. While segmentation of the market will provide opportunity for realizing non diversifiable risk, as assumed by finance theory, to be provided by any good portfolio. It is also argued, under CAPM and APT models, that higher beta (due to volatility of the market) and high cost of transaction (due to lack of efficiency) will mean risk is high in the Nigerian stock exchange. In summary, looking at things from the portfolio diversification point of view, Nigeria stock exchange is good for investors looking for ways to gain from investing in African stock markets. While from the perspective of efficiency and predictability of returns, Nigerian stock exchange looked unattractive.

Bond trading in Nigerian stock exchange was slow to take off when it is compared with equity trading, this is due to the underdeveloped nature of Nigerian financial system. Foreign bond investors have long history of overlooking African bond market. This is not accidental, many African countries including Nigeria has accumulated billions of Dollars in foreign debt which they have failed to service. In the past, African countries have spent over $12 \%$ of their export earnings in servicing foreign debts. Thus, bad debt phenomenon in African has negative effect on Africa's bond market. In the past only institutions like insurance and pension funds that were forced by law to invest in government bonds did so. History of higher inflation and unpredictable Forex market has contributed in scaring away foreign investors from the market. Nigerian companies have also found it more profitable to raise fund by selling equities or borrowing from banks than through selling bond to the public. The Nigerian authorities were also to blame through lack of creation of awareness on government bonds and that of the corporate sector of the economy. But, this state of affairs has started to change in the last one and half decade. Federal government has established its own debt management office responsible for managing government debt. It is also responsible for selling government issued bond to the public. Various campaigns have been undertaken both in Nigeria and abroad to bring attention of the world to Nigerian government bond. These campaigns include roads shows in major financial capitals of the world. The market has been broaden through introduction of Islamic bond (Sukuk) and the environmentally friendly green bond. But, Nigerian authorities must do better than that to be able to attract reasonable number of investors into the bond market so as to make it big enough for big time investors and companies to start considering it for their bond transaction. Most Nigerians are poor with little income left to invest in bond market, this alone explained the lower liquidity of the bond market. With development of the local bond market, the future potentials 
of the market are enormous. The high volatility and inefficient nature of African stock markets has continued to send bad single about the continent capital market.

\section{Capital market supervision}

In about three occasions in the last ten years, three Director Generals of the Nigerian Security and Exchange Commission were suspended from office on accusation of misappropriation of funds, wasteful expenditures and corruption. First it was Musa Al-Faki, then Ms. Aruma Oteh and most recently Munir Gwarzo in 2018. Ms. Arunma Oteh came into office in 2010 after resignation of her predecessor Musa Al-Faki on allegations of corruption and shady dealings involving the listing of the shares of AP petroleum companies own by Femi Otedola. The Nigerian House of Representative committee on capital market accused Ms. Oteh of wasteful expenditures and corruption. Nigerian authorities have penchant for appointing individuals with foreign qualifications into top positions. Ms. Oteh was recruited from African Development Bank where he held various positions including the position of Vice president corporate management \& corporate service of the bank. She has MBA from Harvard in the USA. The former DG of the Nigerian Stock Exchange (NSE) Ms. Ndidi Okereke and her successor Oscar Onyeama had studied and worked in the US. This is sometimes compared with the case of US oil giant Enron. Enron dilemma has shown that having degrees from top schools around the world is no guarantee for integrity and ethical conducts. Business schools now emphasis ethical conduct in their curriculum. MBA in some business schools include visits to prisons as warning to potential executives. Effective regulation and ethical conduct is the hall mark for financial sector worldwide. While security commissions around the world are developing mechanisms to deal with challenges that arise after the last global financial meltdown, SEC in Nigeria looks elsewhere. In the fifty years' history of the commission it has lagged behind the Nigerian stock exchange which it was supposed to supervise, just like the central bank supervision of banks. Nigerian capital market, as an emerging market, has failed to live up to it potentials instead trailing behind its competitors such as those of Egypt and South Africa. For example, bond issuing in the market is still at primary stage of development, likewise the development of ethical instruments such as the Islamic bond Sukuk. In term of corporate governance, a lot need to be done to improve the standing of the market. The contribution of capital market to the development of developing economies such as that of Nigeria cannot be under estimated, needless to say one does not need to explain it here. For example, the rapid development of the financial superstructure in Malaysia and Singapore would not have taken placed without the simultaneous development of their capital markets.

other capital market problems in Nigeria have gone unattended. These include proliferations of illegal funds and wonder banks, capital market frauds, increase in the number of ill motivated fund managers and lack of enforcement of the commission regulations. Oteh's SEC introduced market makers into the Nigerian capital market scene to help the market get out of its problems and put it in better position to compete with more advanced rivals. The issue of 
debt overload that had slow down the exuberance of stock broking firms was resolved through forbearance packages (not without their own controversies) to selected stock broking firms. These measures have helped restore investors' confidence in the market. The forbearance program involved about N22.6 Billion worth of toxic margin loans on the balance sheet of some 84 stock broking firms. Just like in the case of the banking sector, Asset Management Corporation of Nigeria (AMCON) was the one who led the way in facilitated the debt buyout. In the past SEC leadership tussles with Nigerian national assembly had distracted them from focusing on implementing the needed capital market reforms. This was evident looking at the fact that in the face of many capital market problems that resulted from the previous financial crisis, Oteh SEC was able to resolve only few of them. SEC introduced mechanism for corporate organisations in the country to tap the vast Islamic bond market. This was supposed to further deepen the Nigerian capital market and increase the availability of different market instruments. The main barometer for measuring the health of any economy is how fast it raises capital. In Nigeria, the comatose nature of the economy combines with bureaucracy and leadership tussles made that difficult to achieve.

\section{Effect of government policy on capital market}

Since early 2014, the performance of the Nigerian stock exchange (NSE) is in fact abysmal, resulting in shading of billions of Naira in value by the market. At the end of 2014 the market ended as one of the worst in the world, prompting investors to be cautious in putting their money in the NSE. According to Oscar Onyema, chief executive officer of the NSE, the market has lost $\$ 30$ bn between 2014 to 2016. But in 2013, the market performance was better than a year later, as it ended the year as one of the most performing markets in the emerging markets. In 2015 the uncertainty associated with the general election made matters worse for the market, as nobody was sure of what was going to happen after announcement of the presidential election results. It was also not unconnected with the fall in crude oil price, Nigeria major foreign earner, and the global economic slowdown. In China alone, the world second largest economy, the stock market had lost a lot of value in the same period. Likewise, other emerging stock markets of Russia, Brazil, and South Africa have all lost values during the period. But, how did Buhari economic policy or lack of sound policies contributed to the poor performance of the market? The fact that Nigerian stock exchange is more responsive to what happen in the domestic economy than shocks coming from abroad, explain why the market followed performance of Buhari in managing Nigerian economy. But, this did not mean outside events do not influence the NSE. Nigerian stock exchange responded to shocks from abroad, particularly from regional trading partners like South Africa's stock exchange.

Nationalism and restoration of Nigeria prestige in the eyes of the global community was at the centre of President Buhari economic agenda. It was the same policy that anchored President desire to restore the value of Naira as well as his initial refusal to devalue the Naira. His drive to make Nigeria self-sufficient in manufacturing and food production is part of the same policy of 
economic nationalism. In many ways one should not blame Mr. President, that was his first year in office (even former President Obasanjo suffered the same fate during his early years). Buhari inherited an economy that was in bad shape, Naira was already performing poorly in the market, crude oil price had collapsed, the mounting subsidy debt of the previous government, insecurity, corruption, to mention just a few. Added to that, Mr. President himself was still believing that the economic policies that worked in the 1970 and 1980s would work in 2015. Some of his advisers also believed the same. In one of his official visits to china, President Buhari was sold the idea of currency swap between Nigeria's Naira and Chinese Yuan. It was to be done with the intention of reducing demand for Dollar (which many believed was the source of problems in the Forex market), therefore, avoiding subsequent devaluation of the Naira. But, just like with Chinese Yuan, which everyone agreed was undervalued, a nation like Nigeria should devalue her currency in order to make her export cheaper to outside world. But, like Mr. President rightly argued before, a nation that exported nothing but crude oil has not much to worry about making her export cheaper through devaluation. But, less than a year later, President Buhari bowed to pressure and allowed market force to determine Naira value against the Dollar.

Critics of President Buhari have pointed out his lack of passion for the economy (leaving the economy to take care of itself) through his unwritten philosophy of 'if you fight corruption in Nigeria everything would be right'. From 2015 to 2017, the economy was in a critical condition, inflation in double digit, GDP in negative growth for almost two consecutive quarters as well as the subsequent increased in unemployment. The stock market crashed by N1.732 trillion within one year of his government coming to power. But that notwithstanding, the President seemed to have realized some of his policy mistakes, as seen from his renew focus on the economy, inviting some professionals to do the job of advising the government on what to do to put the economy on growth path. The delay experienced before the passing of annual budgets has contributed in slowing down the growth of the economy. The executive legislative impasse was the cause of budget delays. President Buhari should listen to his critics on the handling of the economy, positive criticisms would no doubt help him in running the economy better. The President decision to allow CBN to adopt flexible exchange rate was wise decision. Initially, Nigerian authorities had held the Naira at N197-N199 to the US Dollar since March of 2015, when other oil exporters from Russia, Colombia to Malaysia had let their currencies drop amid the slump in global crude prices since the middle of 2014.

The effect of Buhari government decision to allow Naira to trade freely was instantaneous in the way it affected the Forex market. Immediately after the announcement of the expected liberalization of the Nigerian currency market, in one single day the stock market added some N354 Billion as foreign investors rushed to return their money back after shying away from the economy. There are empirical evidences that linked liberalization of foreign exchange markets with greater inflow of foreign investments. For example, a study by Dimitrova (2005) find a link between higher stock price and weak currency in the US during short term period. The notion of capital control is at the back of nations attempt to impose fixed exchange rate. Since early days of Buhari government, Central Bank of Nigeria has imposed some capital control in a move to 
stop deterioration in the value of Naira, that include banning of importation of 41 items, limiting daily withdrawals with domiciliary accounts, control of Bureau De Change, and so on. The decision to impose capital controls had led to the withdrawal of Nigeria from emerging market indices such JP Morgan's Government Bond Index-Emerging Markets as well as from Barclays index and Morgan Stanley Index. On the other hand, the capital control has helped reduced speculative attacks on the currency and the equity markets, it has also controlled the importation of luxury goods that the country could do without as well as reorient the priorities of Nigerian business community toward looking inward instead of the rushed abroad to import things Nigeria can produce internally.

\section{Foreign investments}

Investment in most occasions is risky undertaking, to reduce riskiness of investment international investors diversify their investments between different sectors, regions, and countries. An important diversification strategy is diversification into emerging economies that comprises the developing countries of Eastern Europe, Asia, Africa and Latin America. It is argued that emerging economies sometimes move in opposite directions of the developed economies. This helped in reducing overall risk involves in any diversified investment portfolio. Nigeria falls into this group of emerging markets. Nigeria is endowed with large population, abundant natural resources, and huge investment potentials. Nigerian banks have attracted the attention of international investors resulting in investment of Billions of Naira in the Banking sector. As sub Saharan Africa largest economy, Nigeria's banking sector is second only to South Africa; this place Nigeria in a strategically important investment destination position. The consolidation of the sector in 2005 has produced some of Africa's largest banks, helping to increase the amount of foreign investment coming into the sector. In the past, the mess that surfaced at the peak of the global economic crisis of 2008 has put fear in the mind of global investors. But, progress has also been made a long that line.

Foreign investors are not philanthropies; many of them are greedy capitalists bent on maximizing returns they get from any one Dollar invested. Put yourself in shoes of international investor with the whole world as where to invest your money. As enlighten investor you will be expected to first considered safety of your investment, then the returns your investment can fetch unless you are a risk lover. Looking at past scandals in Nigerian banking industry how sure are you your investment would not depreciate instead of appreciating. Yes, surely even those that put money in United States' Wall Street have reasons to complain on how their money was utilized before the crisis. But, that have taught investors an important lesson to be wary of bankers in charge of their investments. Absence of effective corporate governance and strong risk management regime have left many questions begin for answers. For example, is Nigeria banking sector good enough, compared with other emerging markets banking sectors, for foreign capital inflow? Central bank would tell you yes the environment is excellence. But you shall remember it is your money they will manage, because of that you will make sure there are 
safeguards to protect and maximize your investment. CBN has done a lot to improve level of corporate governance in banking sector but more need to be done. The composition of the board of directors in Nigerian banks is reflection of what was before the crisis. Board members are answerable to the executive director not shareholders. Executive director influenced appointments into audit and compensation committees of banks. Former managing directors and chairmen were indirectly influencing their former employers.

The establishment of Asset Management Company of Nigeria (AMCON) had helped in boosting confidence of foreign investors in the market. It signaled to them that government was ready to bear responsibilities for the past mess. Likewise, the tough regulatory regime being put in place by CBN. It is believed by some observers that CBN did not have the manpower and technology to effectively manage Nigerian banks. It would take well trained investigators to uncover some of the accounting shenanigans perpetrated in Nigerian banks. But the fact that Sanusi was an insider in the industry has helped in this regard unlike Soludo who came from the academia. But that doesn't mean banks will not invent other methods to beat new regulations. Nigerian banks employ some of the most brilliant minds you could find in Nigeria. Models that allowed capital ratios to be gamed by understating assets' risk and off balance sheet vehicles are example of ingenious ways employ by banks to side step tough regulation. An important means by which foreign investors verified riskiness of their investments prior to making them are international ratings on institutions and governments. Investors do not rely on receiving institutions and countries for unbiased information. For independent views they go to international ratings agencies like Standard \& Poor and Moody. International ratings give investors some knowledge of the risk they are taking by putting money into a particular institution/country. The ratings received by Nigerian banks in the past are nothing to write home about. Nigerian bankers are hoping that investors will side step those ratings. Considering the impact of the financial crisis had on bank's capital base, Nigerian banks are not in position to turn their back on foreign capital. They need it as much as they need regulation from the apex bank. The time for Nigeria to start courting foreign investors is now. Other African countries such as South Africa, Uganda, Egypt, Kenya and Ethiopia have been competing hand in hand with capital market experts to attract the same investors.

As one of the fastest growing economies on the continent, Nigeria need stable atmosphere to maintain higher economic growth rate. Insecurity and poor infrastructures are two major threats to high economic grow rate. High inflation another important barometer together with depreciation in value of Naira will make the atmosphere hot. Despite, creaking infrastructure, foreign investors continued to pour money into Nigeria over the last one decade. The investment climate was unpredictable, until mounting security challenges are tackled. Foreign investors, unlike domestic investors such as Dangote, are motivated by factors other than those that motivated domestic investors. For example, apart from profit from investment, a major consideration for any investor is security of his investment. If they are doubtful of this, their confidence in Nigeria is weaken. So the first thing any country that desire foreign investments does, is guaranteeing security of investment, failure to do that reduces investments. No other 
African country has the diverse potentials Nigeria is endowed with, both human and materials resources. With population of over 190 million, Nigeria is 7th most populous nation and 32nd biggest economy in the world according to CIA World fact book. Notwithstanding these potentials, Nigeria ranked among the poorest countries in the world with one of the lowest GDP per head, ranked behind neighbors such as Ghana in attracting foreign direct investment (FDI) per capita, and ravaged by chronic poverty. In term of indicators for attracting foreign investment Nigeria is also far behind. For example, measures such as World Bank ease of doing business ranking, electricity generation per person, state of infrastructures, legal and court reforms, corruption, just to mention a few. Unlike portfolio investment, FDI is the kind of investment required for creation of jobs in the real sector of an economy. According to some estimates, Nigeria has 11th largest workforces in the world, with about $70 \%$ working in agricultural sector, $70 \%$ of its citizens living below poverty line. It shows link existing between poverty and agricultural activities, a relationship policy makers continued to ignore. Interestingly, China which accounted for most of investment in agriculture and mineral sectors in emerging countries has reduced her investment inflow into Nigeria. The bulk of Nigerian foreign investment is speculative investment targeting equity market coming from UK, and US.

The most attractive destinations for FDI in the world did not achieve their positions for nothing. They have good infrastructures, political stability, security and stable macroeconomic environment. I always say it that foreign investors are not philanthropies, but profit maximizing and risk minimizing businessmen looking for conducive environment for investment of their money. Places like New York, London, Paris, Dubai, Hong Kong, and Singapore that are darling of investors are known for world class infrastructures. Talking of Nigerian infrastructures and administration, right from the point of entry - our Airports- an investors will have a glimpse of what await him. Nigeria's airports are ranked 83th in the world. We are ranked a distance 160th in the world in term of internet hosts. The problem of insecurity is enough a challenge to send foreign investors away. If you are thinking foreign investors are not aware of these you are wrong, international investors pay world class consultancy firms fees to advise them on where to put their money. The global economy was in bad shape before it later recovery, countries from Greece, Ireland, Spain, Argentina and Italy to the US were mired in debt problems. The global outlook for Oil, Nigeria's main export is also not very promising. The uncertainties of the global economy will continue to push investors away from longer term engagements required by FDI into short term engagements - the equities and bonds. Despite these challenges, Nigeria future potential is bright considering the potentials on ground; concerted effort must be made into putting the economy on track. 


\section{TRADE AND BUSINESS MANAGEMENT}

\section{$\underline{\text { Retail Business }}$}

Business decision whether at local or international level require some level of thinking, it requires strategic decision making. According to Johnson and Scholes (1997), strategy is 'matching of the activities of an organisation to the environment in which it operates'. This subsection intends to take reader around some of the intricate of Nigerian retail business environment. International companies have to understand the working of market beyond their domestic environment. What made the most successful firms in the market succeeded and what to avoid regarding cultural clashes and religious taboos? Recently, Nigeria has made headline for the wrong reason: Boko Haram, but that security threat has been nearly eliminated. Investors in Nigeria have to look beyond Boko Haram, at other critical success factors to help them thrive in Nigerian environment. In Africa, just like elsewhere around the world there is a rise in the number of modern business owners who run their newly formed businesses in line with global standard, putting Africa on the map as continent with great potentials. In Nigeria the adaptation of modern business techniques has been phenomenal, ranging from modern shopping malls, online retail businesses, hospitality management to private universities. Majority of these modern enterprises are homegrown headed by Nigerians with passion to change the shape of how business is conducted. The privatisation of government enterprises of the last decade has further opened Nigerian economy to the private enterprises, increasing competition and further attracting foreign investment. Nigeria has unique advantage in economics of scale due to large population that no other African country can challenge. This made it more profitable for any businessman to use Nigeria as his lunching ground from where to penetrate other Africa markets. The fact that Nigerian GDP and population made up nearly half of ECOWAS GDP and population is pointer to weight of Nigeria in African matters.

Though substantial number of Nigerians live below poverty line, about $65 \%$ according to some estimates the population of middle class in Nigeria is still very big. The population of Nigeria is over 190 million, based on the $35 \%$ population that is above poverty line, you have 66.5 million people with big pockets to make purchases in the Nigeria vast retail market. This number is more 
than the entire population of South Africa, the second biggest economy on the continent. With GDP of about $\$ 450$ billion, Nigeria is indeed a big retail market in Africa; though many investors around the world failed to take this into consideration when they were drawing their investment plans. In the minds of many western investors Nigeria is a chaotic place to do business, cramped with people who barely understand the working of the modern world. This impression is wrong; I agree that Nigeria is a chaotic place, but when you look beyond the negative headlines there is a lot of profit underneath, what economists called abnormal profit. Ask Aliko Dangote, the richest man on the continent who made his billions in Nigeria. Yes, I concur there are risks involve in investing in Nigeria but tell me one place in the world one invests without facing one form of risk or another. The law of profit as we all knew says that where there is profit there is risk; not necessarily the kind of deadly and toxic risks we have seen during the global economic crisis of 2008. Despite the manner investors viewed Nigerian market, there are large number of people who see the country differently. The annual foreign direct investment (FDI) coming into Nigeria is in billions of US Dollars, and foreign retail companies are coming into Nigeria to open shops.

In the latest world bank ease of doing business ranking 2018, Nigeria was ranked $145^{\text {th }}$. Nigerian retail sector has the potential to be third most dynamic sector after banking industry and telecommunication. Its growth in term of revenue and profit will multiply as the economic grow and size of the middle class expands. Foreign retail companies were in rush to set up shops in Nigeria in a growing list that include, Shoprite, Mega plaza, Spar etc. Numbers of domestic companies that are modernizing and expanding are increasing in number. Though, small scale retail stores account for substantial number of retailers in Nigeria, big corporate entities are making inroad. The growing pool of young consumers and high economic growth are magnets for attracting retail investments. The fast growing industries with diversification benefits are electricity, manufacturing, banking \& finance, housing and retailing. Global multi nationals planning to enter Nigeria must study regional environments' peculiarities. Unlike in developed countries of the world, there is infrastructural deficiency in Nigeria and other African countries. But, recently Nigeria has witnessed massive infrastructural investment undertaken by the federal government.

Most of Nigeria big shopping malls are located in Lagos and Abuja. Other parts of the country that have great promise for retail industry includes Kano, Port Harcourt, Kaduna, Enugu and Ibadan. These states capitals have substantial number of middle class families, and supporting businesses. Kano's Ado Bayero mall is the biggest mall in Northern Nigeria, located in former site of Kano trade fair complex with parking space for thousands of cars. The informal retail market in Nigeria, though, unorganized is big. Nigeria is full of people with moderate level of brand recognition. When a Nigerian says he is for Dangote or Nestle he means it and follows his word with action by sticking with the product. This explains the reason why some retail stores succeeded better than others, people patronize some stores because of the low price of their products, others because of the quality of the products in display. While for others it is the location and building housing the shop. For example, Sahad stores, an indigenous super market that originated from Kano decades ago, boast one of the biggest shopping mall in Abuja and Kano 
making hundreds of millions Naira in annual revenue. One of the major attractions of Sahad stores according to shoppers patronizing the store is low price. But, that should not be surprising taken into consideration back ground of the owners and the pioneer location from which they started the business, Kano (known nationwide for its retail trade and low price).

The big stores available in states capitals in the 70s and 80s such as Leventis, Super Stores are relics. Today there are only old warehouses to remember they existed. The economic problems of the 1980s were responsible for the demise of these retail stores. Structural adjustment program (SAP) of Ibrahim Babangida military regime, together with the recession that accompanied it combined to banish the middle class of the period, leaving the country with two extremes: the upper rich and the bottom poor. This trend particularly led to the grow of informal retail sector at the expense of big retail stores. But on optimistic note, as the economy grows and middle class population increases, so do the big retail stores. Despite Nigeria being among top countries in Africa in term of internet usage, its retail market has lagged behind in innovation and E-commerce. Though, online firms such as Konga and Jumia are spring up acting as Nigeria's equivalent of American online giant Wal-Mart, that sales things online. There are proliferation of versions of Wal-Mart and Amazon in countries such as Turkey, Brazil, China, Indian and Russia. Internet has revolutionized the traditional way of doing things in industries such as Newspaper, Television broadcast, Music sale, retailing, education, healthcare, and Airlines operations. Any investor who take internet for granted in his investment planning in Nigeria do so at his own risks.

\section{Brand Building}

Kotler (2006) defined branding as 'a name, term, symbol or design (or combination of them) which is intended to signify the goods or services of one seller or group of sellers and to differentiate them from those of the competitors'. Strong brand took years to be molded to what they later become. No brand was ever built in a day it took marketing, advertising, word of mouth, direct sale and packaging. In a developing country like Nigeria word of mouth played an important role in spreading a brand messages. Early users told others about the benefits, attributes, and values derivable from the brand. In every market segment there is a brand leader. According to Hindle (2010), 'when a branded product becomes number one in its market category it is called a brand leader'. A brand leader tends to be well accepted by the market and provide certain benefits to users than competitor brands. In Nigeria, with a lot of poor people, brand strategy that worked in US might not work in Nigeria. But, a strategy that succeeded in India or Pakistan might succeed in Nigeria due to shared similarities. International firm venturing into new territories must be cautious of culture and traditions of the host nation in framing their brand names and marketing. In Africa and Middle East, socio-religious considerations are very important in determining how consumers perceived any brand. Consumers in Nigeria are generally ethically oriented, opposing wastefulness and being more religious (Abdullahi, 2018). Muslims in Nigeria considered Islam as important variable in determining how they relate with any brand (Abdullahi, 2017). 
Nigerian business environment is indeed very unique not your typical business atmosphere in the developed world of Europe and America. The same way that when you are doing business in Asia you have to put the uniqueness of the Asian environment at the back of your mind; the same apply to Nigeria. When in Nigeria, one has to acknowledge that he is in Nigerian corner of the vast continent of Africa. Factors such as culture, religious practices, geography must be included in any strategic master plan for penetrating the market. There are over three hundred and fifty (350) ethnic groups in Nigeria, differing religious practices and varied climatic conditions from the rainy Rainforest in the south to arid climate of the extreme North. Likewise, the distribution of wealth between these diverse areas is not evenly distributed, while the North has rich and poor peasant farmers, the South is crammed with middle class city dwellers, poor villagers and unemployed graduates. While an average Hausa man in the North get most of his news and entertainment from radio, a middle income Yoruba man prefers to read the daily paper. But, for an Igbo man in the South, TV is his prefer choice; if anything he wanted to watch his favourite Nigerian film. While a typical northern elite is politically inclined, the northern rural poor is worried about his farm; as for Yoruba elite he/she is a corporate individual and for his lower ranking tribesman he/she is a civil servant or trader. But for the Igbo elite, he is a businessman with vision to transform into a politician, while his poor lgbo brother is a trader or rural dweller. In the North religion is an important barometer in measuring brands, but in the South religion play a lesser role as cultural and economic considerations compete for prominence. Corruption is endemic in the Nigerian public sector making some big brand names to go out of their ways in order to get government approval of the products or services they were selling.

There are hundreds of brands in the Nigerian market. Popular brands in Nigeria includes Dangote, GTBank, First Bank, Nestle, MTN, Glo, Coca Cola, Cadbury, PZ Cussons, Unilever, Zenith Bank, UBA, Ja'iz Bank, BUA, Golden Penny, Ashaka Cement, Thisday, Daily Trust, Oando, AP, Total, to mention to just a few. Like in any other economy around the world, building a brand is not a one-day affair. It takes years to build a strong brand. None of the brands above was built in less than 10 years. Brands like First bank are over a century old, while others like telecommunication giant Glo take about a decade to build. It takes a lot of hard work, creativity, and money to achieve brand success. Normally, a brand main vision is for long term sustainability not short term profit. For example, Daily Trust, a newspaper that originated from Kaduna in 1998 and later moved to Abuja, has the long term vision of being a world class media company that earns public trust. To be world class and earn public trust cannot be achieved in one day or even a decade. Some of the biggest media companies in the world like the Economists magazine of London and New York Times have been in existence for over a century. Dangote brands in the Nigerian market are known for their quality, likewise the goods produced by Nestle. Nigerian consumer value quality much, this is because of the economic conditions he found himself where valuable commodities were scarce. The situation, therefore, left consumers with no option than to look for value for money. In certain contexts, Nigeria consumer manages with goods of lower quality because of considerations such as the exorbitant price charged for high quality goods or services. 
Brand consciousness and impression is important for brand's long term sustainability. An average Nigerian valued word of mouth highly, if a friend or neighbor said that he tried a product and found it good, the impression remains in his mind. He kept the impression, even when others brought counter idea about the products. Many brands names had used this knowledge to maintain market lead. Take for example first Bank, Nigerians believed First bank is the safest bank. The same thing applies to Panadol, a pain killer. People believed if a pain killer was not Panadol then it was not a pain killer. Even in presence of new tablets that perform better than Panadol, this made the parent company to come with a more powerful pain killer called Panadol Extra (a kind of brand extension). Some Nigerian brands made it because they were first in a particular niche. All paracetamols were called Panadol irrespective of their brand names. It was normal to hear a prospective buyer entering pharmaceutical shop asking 'give me Panadol', the shop attainder knew what he was asking was paracetamol. Therefore, he gave the buyer any brand of paracetamol, unless he was very specific. Another product first in a market whose name became synonym with products in the market segment was OMO, a powder detergent. Today, in some parts of Nigeria, every detergent is OMO, whether it is Klin, or Elephant. First to enter a market, has important role to play in shaping the future of a brand. This also explained why late enterers found it difficult to establish in a market segment, unless they came with highly innovative product.

Role of medium of communication in creating brand awareness. As most populous country in Africa with over 190 million people, a brand needs a widespread medium to take its story to potential customers. Nigerian geographical regions or tribes have individual mediums of receiving information and advertisements. Radio dominated in the north, TV in the south; though as the economy of Nigeria grows this line of distinction will blur. There are over twenty national newspapers and magazines in Nigeria. Some of the big newspapers include The Guardian, The Punch, Daily Trust, Thisday, Vanguard, The News, The Tell, News watch, The Sun, Leadership, The Nation, People Daily, National Mirror, and Blueprint. Likewise, for TV and Radio stations, there are over hundreds of them from Lagos to Kano, Port Harcourt to Abuja. There are also satellite channels that are coming on stream, as well as internet mediums for advertisers to sell their brands. Telecommunication companies and banks such as MTN, Glo, GTBank, and First bank are major advertisers in Nigeria spending billions of Naira in advert budget. They used the mediums mention above including outdoor advertising to achieve their commercial goals. It is not surprising, therefore, that these brands have become what they are today looking at the diverse strategy they used to communicate their brands messages to target audience. Newspapers in Nigeria made billions of Naira from advert annually making it their major source of revenue more than what they realized from paper sales. These big brands also sponsored major programs and events such as sport (MTN and Glo), entertainment shows (MTN, Glo, and Etisalat), Carnivals (Dangote and Etisalat), Musicals (MTN, Glo and Etisalat), and foundations (Dangote and MTN). The marketing communication industry in Nigeria is yet to mature like in developed countries. But, it is playing important role in brand communication in Nigeria. It is difficult for any major 
brand to sustain its appeal in Nigerian without involving media, looking at competitive nature of Nigerian market.

\section{Business conglomerates}

This section compares family businesses in Nigeria and India. It contrasts conglomerate business model with specialised shareholder model. It was the American approach to business management that spearheaded the global obsession with $\mathrm{MBA}$, as prequalification for success in modern business environment. An MBA from Harvard, Chicago, London Wharton, Stanford, or INSEAD was what an inspiring youngster needed to secure a good white collar job that paid around $\$ 110,879$ with prospects of making it to the top of his choosing career. Business schools around the world running MBA programs are in thousands, spread from United States to Japan, Oslo to Cape Town; making billions of Dollars in the process. Here in Nigeria we have relatively good business schools such as the Lagos Business School and Dangote Business school in BUK, Kano. Though academic studies have found little correlation between producing a business Guru and possession of an MBA degree, recruiters still value applicants with the degree because it is a positive signal. Prominent managers in the business world from Jack Welch, Bill Gate, to Steve Jobs achieved their world renown feats without having MBAs; likewise, thousands other business Gurus around the globe. While examples abound of big corporations, who despite in-house policy of recruiting top MBAs had collapsed. The problem of valuing qualifications over experiences reached its climax when the US energy giant Enron collapsed. Enron collapsed and that of other giants such as long-term capital management (LTCM) had sent a strong signal to the corporate world.

Kano Nigeria is well known as a major commercial centre in West Africa with long history of commerce. Centuries of business have made Kano distinct among its neighbors. A market place, in fact most economic goods located in Kano are ready for trading. Every inch of space around Kano city is a potential market place. These explained attraction of Kano to business people from around the world. It also explained the cosmopolitan nature of the ancient Kano city with locals tracing their ancestral roots to faraway places like Yemen, Syria, Mali, Libya, Senegal, Ethiopia, Sudan, Burkina Faso etc. Writing on the success of Kano as a commercial centre Ibrahim Ado Kurawa (2006) observes, "The Jihad leaders of the caliphate encouraged Kola nut trade and Kano was the greatest beneficiary with an annual turnover of about $\$ 30$ million. Kano merchants were also very innovative and they were able to integrate commerce and craft industry during the precolonial Kano, contributed to the prosperity of the province. Kano was producing an estimated 10 million pairs of sandals during that period because of economic harmony. Sarkin Kano Alhaji Muhammadu Sanusi (1953-1963) established the Bompai Industrial Estate". At the heart of Kano success as centre of commerce, was roles played by rulers to ensure the sustenance of Kano as 
trading point for the entire region. Even after the Jihad of Usman Dan Fodio, Kano remained the most successful and rich of all the provinces in the caliphate.

Kano markets attract hundreds of visitors from neighboring countries such as Niger, Burkina Faso, Chad, Cameroun, central Africa republic, Benin and Togo. The major occupation of Kano resident remains trading, which explain the reason why Kano produces some of the most successful business individuals in Nigeria. One of the oldest market places in west Africa in existence today is Kurmi market (established by the emir of Kano Muhammadu Rumfa in 16th century CE). It still retains its old friendly atmosphere, candor and attraction. Other major markets in Kano includes Dawanau grain market (largest in West Africa), Sabon Gari market, Singer market, Rimi market, Kofar Ruwa, Kantin Kwari, to mention just a few. Kano has a sizeable number of industries, the largest outside Lagos. According to a Kano state document (K-SEED, 2004), Kantin Kwari textile market, was valued at N20 Billion in 2004; about 14 years ago, it current value will be in hundreds billions Naira. This subsection looks at successful business dynasties in the ancient city. The problem with this area of study is little work was done by business scholars. The few works available were written by historians and sociologists.

Agalawa are renown in this region as the most business conscious group in Hausa land, before and after Jihad of Usman Dan Fodio. According to some scholars, their origin is linked to Tamashek speaking people of the Sahara Desert. Though, they were concentrated in Kano they were also found in Katsina, Borno and other parts of Hausa land. According to Dan Asabe (1995), the patronage, encouragement, and protection given to Agalawa by emirs and rulers of Sokoto caliphate helped in the success of their businesses. Prominent examples of successful Kano businessmen with Agalawa origin includes, Kundila (d. 1901), Umaru Sharubutu (d. 1944), Adamu Jakada (d. 1942), Maikano Agogo (d. 1946), Alhassan Dantata (d. 1955), and Iliasu Dandagomba (d. 1952). On their habits, Dan Asabe (1995), wrote: "But they remained largely endogamous, and thus because of this, they were in any particular area almost all related to one another. They were unostentatious, frugal and in most cases ate only once a day - usually a late evening meal. They maintained friendly relations with local rulers and attempted to avoid confrontations with them. They regard long-distance trade as their natural way of life and indeed, almost as a religious obligation. They rightly argued that prophet Muhammad and all his close companions were, by profession long-distance traders". They learnt their business skills by apprenticeship, moving from market to market, house to house selling goods. Traditional Agalawa businessmen moved together with their families on trading expedition, a kind of nomadic live. The business families discussed below with the exception of Isyaka Rabiu traced their roots to Agalawa.

But before discussing these families, a country that provide an interesting case study of its own is India. It has the best of the two worlds, obsession with university qualifications prominent in the Western world and conservative business tradition that emphasizes family connection and local knowledge. As one of the fast growing economies in the world, India provided ample opportunities for young entrepreneurs to put their skills to practice. This has provided old businesses such as Tata group, Reliance industries, and Mahindra group chance to consolidate 
without muscling air out of new comers and start-ups. One feature of Indian business that baffled Western Management Gurus was conglomerates business models. Conglomerates, that join different lines of business under one roof, differs from Western style specialized business that focus on one line of business. Most of the giant of Indian business that made global headlines in the past fifty years were conglomerates. Examples here include Tata groups, Reliance industries, Mahindra group, Bharti, and Essar. A prominent Western styled business in India is Infosys, it specialized in IT software business. But, companies such as Infosys are the exception rather than the rule in India's murky business environment. Family control business is not unique to India, it is a common feature in developing and newly developed countries. Examples include, Chaebol in South Korea, Dantata here in Nigeria, Sawiris in Egypt to mention just a few. But, changes are occurring in the way family business are run in the developing economies. The ascension of young generation of mangers who received education in the West to managerial positions previously occupied by their parents and grandfathers is one of these changes. According to some estimates, family businesses account for some $70 \%$ of total sales of India 250 biggest private companies.

Modern business executives such as Jack Welch are rare among the old guard of Indian business builders. Jack Welch firmly believed in capitalist mode of production and its emphasis on shareholders over other stakeholders. Indian executives, due to old linkages to socialist and central command system of Indian economy of post-independence period, were skeptical towards capitalist shareholder model of business. A turning point in Indian business environment was liberalization of the economy in 1991 that opened the economy to competition. As a result of the liberalization Western style business corporations evolves, threatening to take away market share from family control businesses. Despite success of companies such as Infosys, American style businesses have a long way to go in taking away market share from the traditional conglomerate firms that dominate Indian business environment. A feature common to family businesses in India is being cautious in investment undertakings. They test waters with small investments followed later by large investments. This in some ways has prevented them from riskier investments, but at the same time divorced them from big windfalls that come with such risky investments. Riskier investment tends to be undertaking by new-generation investors who cut teeth in Western world. In Nigeria businessmen like Dangote provide a good example of successful business individuals who come from wealthy business family but at the same time excel because of adaptation of Western style business. Though Dangote is educated up to Masters of business management level, his business empire like that of Tata of India is a conglomerate rather than specialize business such as example of American technology giant Apple.

Dantata is household name when talking of wealth in Kano. Alhaji Alhassan Dantata the patriarch of Dantata family died in the year 1955. He was reported to be the wealthiest person in West Africa who first specialized in Kola nuts trade before branching to other trades. Dantata moved to Ghana from Kano during his early life where he started his Kola nut trade at Gonja. It was from there that, in later years, Dantata started moving Kola from Ghana to Nigeria. After becoming famous in diversified businesses, Dantata became agent for Royal Niger Company 
(RNC) in the North in charge of groundnut trade. Dantata is one famous examples of Agalawa clan known for their business exploits. He is most known example of the remaining clan members. The clan went into oblivion with the coming of European colonialists and modern style of business. Dantata is a devout Muslim who shunned interest dealings. He had visited Mecca for Hajj during his lifetime. He was disciplined businessman who avoided politics despite connection to power. Alhaji Sanusi Dantata is well-known son of Alhassan Dantata who became famous in his father's groundnut trade. Dantatas were known for their system of credit allocation within the family line. It was through one of these credits Alhaji Aliko Dangote received his initial starting capitals around 1977 from Sanusi Dantata who is Dangote's grandfather from the part of his mother Mariya Sanusi Dantata. Through the use of agents dispersed in towns and rural areas, Sanusi Dantata and his brother Aminu bought agricultural commodities and livestock from rural areas and kept them in major ware houses. Late Abdulkadir Dantata is the eldest son of Sanusi Dantata who apart from traditional merchandise trading and importation, established Dantata \& Sawoe one of the biggest construction firms in Nigeria. Abdulkadir Dantata was in the past listed among forty richest Africans and was on the inaugural list of 40 wealthiest African by Forbes magazine.

Aminu Dantata who I had mentioned earlier is the richest son of Alhassan Dantata. Born in 1931, Aminu like his brother started in the family business before moving into administration with the creation of Kano state where he became commissioner of commerce. He later left government and went back to his family business where he actively participated in the establishment of industries in Kano state at that period. Apart from establishing and buying shares of newly created industries in Kano, Aminu engaged in importation business, where he was active in the importation and the distribution of fertilizer, cement, chemicals, building materials, and automobiles. Aminu was director in over 21 companies. Unlike the like of Dangote, Aminu Dantata is a conservative businessman who had substantial number of his investments closer to home. He is very active in real estate business where he owns a lot of properties in Kano. Aminu like his father spend a lot of his wealth in philanthropic work, he was chancellor of Katsina Islamic university. Tajuddeen Dantata is a son of Aminu Dantata who is also very active in the family business, as he manages million dollars of his own and his father's wealth. Unlike his father Aminu Dantata, Tajuddeen received conventional business education in Nigeria, United Kingdom, Saudi Arabia, and Egypt. He is on the board of many Nigeria firms where his family have substantial interests. With the help of his family business and connections, he has proven to be an upcoming boardrooms star coming from the Dantata family. Alhaji Sayyu Dantata who is mechanical engineer by training was once head of Dangote transport section before moving into his own business with the establishment of MRS, one of Nigeria's major oil companies'. After acquisition of Texaco/Chevron Nigeria limited by MRS, Sayyu Dantata was considered one of the richest upcoming billionaires in Nigeria. Like Tajuddeen Dantata, Sayyu business approach is modernistic.

Aliko Dangote has carved a niche for himself in business management in Africa. He was previously listed among world top Billionaires as richest African, the only Kano indigene and 
Nigerian businessman to ever attain such a feat. Born to family of Dangote on the side of his father and Dantata on the side of his mother. Dangote received both conventional and Islamic education, with a degree in Business administration from a university in Egypt. Dangote combined traditional family business skill with modern management techniques. Like other Kano businessmen that came from established business families, Dangote cut his teeth in family business. He branched out to set up on his own with loan from his grandfather. He started as a trader importing commodities from outside the country in 1977. Dangote has succeeded in building the largest business conglomerate in Nigeria, that manufactured things from cement, sugar, flour, noodles, juice, Textile, sacks, to iron, petroleum products and steel. He followed in the footsteps of his great grandfather Alhassan Dantata who was richest person of his time and most daring and adventurous, entering businesses most businessmen avoided. Dangote has become a modern Ba'agale (from Agalawa) who traversed the African continent in search of profit. Dangote has invested billions of Dollars in African countries to shore up his empires in Sugar and cement business. Like other international businessmen, Dangote is broadminded, adopt to new environments fast; an example is his second home Lagos which has become his first home now.

Dangote is an ambitious business tycoon. He was quoted as saying he hoped to become fifth richest individual in the world. These and his vision explained his voracious acquisition of assets around Africa. Like most family business, Dangote group (his major company) has appointed number of his family members and relatives in top positions. But, in technical managerial position he mostly employed expatriates. Famous among his family members who featured regularly in Dangote business is Sani Dangote who was group vice president of Dangote group. He himself is an established business individual with interest in manufacturing, agriculture, banking, and oil services. He is a junior brother to Dangote. Dangote group has about 13 subsidiaries spreading all over Nigeria and about 14 African countries. Unlike Agalawa who made Kano the centre of their universe, the focal point of Dangote operations is Lagos where his headquarters and major companies are located. Apart from Lagos, other Nigerian states have substantial number of Dangote businesses, Kano (Textile, flour mills, Noodles, sack, and beverages), Benue (cement), Ogun (cement), Rivers (cement terminals), Edo (petrochemicals), Adamawa (sugar), Cross rivers (flour mills), and Kwara (Flour mills). Like earlier Agalawa who developed a good rapport with rulers of their period from Sultan of Sokoto to emir of Kano, Dangote has good working relationship with people in power. But, unlike some Agalawa businessmen who could not adapted to fast changes in their business environment when Europeans arrived, Dangote is quick to adapt to changing circumstances. As Dangote aspire to be among the top five richest individuals in the world, it is possible that centre of his business empire may move from Lagos to London or New York.

Family of Khalifa Isyaka Rabiu is one of famous business families in modern day Kano. Isyaka Rabiu and sons runs Business empire worth hundred millions of dollars. They are considered one of the richest families in Kano state and the nation at large. Isyaka Rabiu grew up in a family with tradition of scholarship (his father is an Islamic scholar). He became vast in Islamic 
scholarship before turning attention to commerce in the 1960s. The disciplinary way of live he acquired during his learning period as Islamic knowledge seeker is believed to have helped in building his business acumen and skills. His networking ability led him to establish business contacts with established Kano businessmen and prominent corporate agencies and government officials. Isyaka Rabiu had vision and optimism to forecast important events coming and where next business opportunity is going to come from. For example, during the 60 s and 70 s he transformed from textile merchant to textile manufacturer by establishing his own company. The oil boom of 1970s left Nigerian economy with abundant cash and higher purchasing power. Isyaka Rabiu was not blind to this opportunity. He actively participated in importation of commodities. This together with the indigenisation policy of that era, saw Rabiu buying shares of formerly foreign own companies, making him one of the richest men of his era. Apart from trading and manufacturing, Isyaka Rabiu engaged in real estate business and construction. Despite his public image as scholarly person especially in Kano, he was viewed as a cut throat businessman like other business personalities. He competed to get what he wanted in the business world of that period and did not fear other competitors.

Famous among children of Isyaka Rabiu is Abdussamad Rabiu Chief Executive Officer of BUA conglomerate, one of Nigeria's leading companies. Abdussamad received his conventional education both in Nigeria and the United States, apart from the Islamic education he received in his youthful age. The goodwill gathered by his father over the years and the huge empire he built had great impact on upbringing of Abdussamad and his growing up to be an important businessman. As a disciplinary person the older Rabiu made sure he gave the same discipline to Abdussamad and made him to take business with seriousness and as a profession for living. He started BUA Company in late $80 \mathrm{~s}$ as a trading company that specialised in the importation of agricultural commodities and chemicals, iron and steel and industrial chemicals. Like was the tradition with Kano businessmen, he started as a local trader and importer before moving into manufacturing. Unlike his father who was educated in Islamic sciences, Abdussamad like many modern Nigerian businessmen is equipped with modern education. He travelled to America where he studied Economics. Thus, Abdussamad is versatile in both modern and traditional business. Skill requested of someone moving a lot from one part of the world to another. Then there is the desire to acquire wealth which is common with Kano businessmen, motivating businessmen to go to the length allowed by law to acquire wealth. With return to democracy in 1999 and large scale privatisation of government own enterprises, Abdussamad bought interests in public companies including Sokoto cement, Delta steel company, ports, Lafiagi sugar company, and Edo cement company. Abdussamad turned these companies into world class businesses, away from the moribund state they were under state control. Other manufacturing business he has been engaged in includes, flour and oil milling, pasta production, oil and gas, shipping, and real estate.

Kano tycoons were obsessed with building conglomerates instead of Anglo-Saxon-style specialized businesses. This was due to different factors among which are the environment they were doing businesses, culture, family tradition and desire to growth wealth in short span of 
time. They were conservative, they hardly go into business areas prohibited by Islam such as alcohol production, except for investments in modern interest base banking system. To them business profession was like a religious duty, they followed rules and did not joke with business matters. The children of the founders of these family businesses unlike their parents have acquired a lot of Western education and business skills. Hence, the similarities with some Indian businesses. Despite Indians obsession with family business, some of the most successful family businesses in the country are run by family members with MBAs. A good example is the Ambani brothers who manage the now split Reliance group. Both Anil Ambani and Mukesh Ambani hold MBAs from Wharton Business School University of Pennsylvania. Even in the West there are still a large number of businesses run by families. Rupert Murdoch business empire is a classic example. There are hundreds of family businesses in Germany and France that are run as successfully as professional businesses. Thus, family run business dominating commerce is not a bad thing, the most important things for these business is to ensure they conform to the globalized world and adapt to changes as they occur. In Nigeria we cannot always say the same thing on family business, many Nigeria's top corporations are owned by diverse shareholders. But, there are large number of family dominated businesses from Kano to Lagos, Sokoto to Aba. Some of the biggest business firms in South Korea such as Samsung, Hyundai, and Daewoo were owned by family groups. Nigeria has a lot to learn from these giants. Even Western Management Gurus are learning new things from these companies. I can recall the time when Obasanjo government tried to revamp the Nigeria private sector and create business behemoth like Korea's Chaebol. The effort failed because of clash of interests and lack of will on the part of those behind the program. Indian business and economy have reached the level they are today because of roles played by family businesses such as Tata. Nigerian entrepreneurs can learn one or two things from this.

\section{Entrepreneurship}

In previous subsection, major business family in Kano Northern Nigeria were identified and discussed, this section will look at entrepreneurship in general. Example, will be provided of individual that served as model entrepreneur. The view of Nigeria as chaotic place, did not help made justice to new generation of entrepreneurs who made use of state of the art management techniques to run their businesses. Nigerian entrepreneurs now employ consultancy firms to work for them in market research, strategy, recruitment and use of information technology. There are a lot of Indian expatriates working in top managerial positions helping to develop Nigerian firms and make them competitive in global environment, using the method they used back home in India which shared features with Nigeria. Modern Nigerian entrepreneurs did not necessarily come out of business families, many of them are self-motivated graduates who had worked in Nigeria or abroad using their spare time to oversee their nascent business ventures. They took advantage of government credit programs to increase capital base. Access to internet has allowed them to retrieve vast amount of information to improve their business venture at 
little or no cost them. This contrast with 1970s to 1990s when modern business knowledge was difficult to share, only select few possessed it. Nigerians had to rely on Europeans in running their fairly large businesses. Looking at the matter using the lens adopted in writing previous section, Hausa entrepreneurs were traditionally hinterland traders who travelled to distance lands to conduct business of buying and selling. The Yoruba also share this feature to a lesser extent but they were influenced by coming of Europeans who directed their focus away from hinterland to the coast. The Igbo entrepreneurs were influenced by the nature of their local environment that was decentralized society, hence, Igbo traders tended to be highly independent and atomistic. This contrast with both Hausa and Yoruba who conducted their trading under the shadow of powerful central authority, mostly emirs and Obas.

It was Schumpeter, an Austrian economist of the 20th century, who popularized the term creative destruction, a term that denotes changes entrepreneurial venture undergoes every time a new process, product or innovative company enters its market niche. In his theory of economic development, Schumpeter explored role of entrepreneur in capitalist economy. To him an entrepreneur is innovator who brought new ideas and applications- an agent of change. The Schumpeterian entrepreneur, as a term commonly used to refer to person who fulfills the definition of the term, according to Braguinsky, Klepper, and Ohyama (2009)," introduces a new good or a new method of production, opens a new market or discovers a new source of supply, or carries out a new organization of an industry. He upsets the conventional way of doing things. When successful, he elicits widespread imitation". Other scholars such as Robert B. Reich sees entrepreneur as a leader, manager, and team builder. Entrepreneur as a risk taker someone who brought factors of production such as labour, capital, resources together to produce physical goods or service. Sometimes a lonely creature who venture where others failed, who volunteer to make a dip in a vast sea where others dare not to. An economic change agent per excellence. The story of Buhari is that of a young man who because of hard work, intelligence, determination and luck has achieved what others who were older than him could not achieved. Buhari as young entrepreneur will subsequently be used as an example of modern entrepreneurs coming from Nigeria.

I first met Buhari in 2006 at British council Kano office. He told how he experimented with different small scale businesses. He was, at one time a fish farmer, other times a poultry owner, book seller, computer mechanic, and retailer. He told me how his business live begun when he was just 15 years old, following in the foot step of his uncle who was dealer in electronic equipment. He was not much interested in having more than a diploma in Business. He travelled to many parts of Nigeria, more especially Lagos, Ilorin, Maiduguri, Port Harcourt, Yola, Enugu, and Sokoto. It was during such trips that he learnt the techniques of aggressive marketing which has helped him in business undertakings. He was a sharp man who noticed new business ideas ahead of competitors. These had helped him in business of moving goods across different geographical areas. He sometimes noticed new business ideas in Lagos which were yet to come to Kano, through sheer determination and wit he would quickly introduced them to Kano. As a result, he made a lot of surpluses before others entered the market. In all these, he took a lot of 
risks such as his new business not accepted in Kano. It was not easy for young entrepreneur like him to move from idea to reality in untested waters. He went into production of Salwa (Quail) eggs after extensive market research. He found the demands for eggs was greater than supply. Therefore, he quickly entered the market to help close the gap. He acquired a large fierce of land which he used to house his poultry farm. He produced up to one thousand eggs on daily basis. He had efficient supply chains through which he sold his eggs to retailers and final users. On why there was such a high demand for the eggs, it was because of medicinal and nutritional values of the egg. These, among others, includes treatment of diabetes, and skin ailments. But, eggs production was not the only business Buhari was into. He was into real estate where he bought old apartment blocks, remodeled them and sold them off. He told me he had made a lot of money in this line of business. The secrete to it is to be imaginative and put an ear to the ground. Sometimes he bought already completed old structures and demolished them down, in order to get the lands ready for new structures. He also had residential and commercial properties he rented out to people.

Alhaji Buhari had built a large network of associates who played important roles in the development of his small business network. Like with any other businessman networking is of significant importance in development of any business, that explained Buhari shrewd sense of networking and his ability to connect with people in both middle and high ranking positions. In Nigeria, the ability to make it in the business environment depended on who you knew, even multi billionaires like Dangote owed their fortune to networking and hobnobbing with those in corridors of power. There was no way you could make it a lone, if the security officials did not get in your way the rent seeking bureaucrat would surely do. Even simple bank loan was not easy to get without access to someone in the system. Banks prefer to give loans to big name organizations or government officials, excluding personal loans they gave to people with salary accounts. All government mantra about giving assistances to small and medium scale enterprises sometimes did not existed outside media propaganda. Even Central Bank commitment to small scale industries had failed to bear fruit, if not of the recent renew efforts by the new government in Abuja. The problems of small business did not stop there, there was problem of power supply. This made it mandatory on businessman to source his power through use of noise making generators. The roads needed for moving final goods to markets were not in good condition, adding to existing problems. In some cases, you must get your own security, because of insecurity in parts of Nigeria. Despite that Buhari found courage to run two medium size companies producing school chairs and varieties of juice.

To most Nigerians, when talking of innovation and entrepreneurship, first thing that come to minds is physical things/products. Though, invention of new product or machine is innovative entrepreneurship, but that is not all that entrepreneurship is about. In fact, mere invention of things does not make one an entrepreneur. What that makes him to be is an inventor. Before an inventor can be called an entrepreneur he must successively take his invention to market. That explain the reason many inventors in history were not entrepreneurs. They left the invention after inventing it for real entrepreneurs to create market for the new invention. Buhari, on his 
part, had never invented a new product or machine, but he is an entrepreneur in the real sense of the term. The fact that he created new marketing procedures to market his products made him an entrepreneur. Likewise, his risk taking abilities and managerial prowess put him in that league. Among his leadership qualities are his sound ethical compass, the ability to take unpleasant decisions, ambition, clarity and focus, and emotional self-confidence. No entrepreneur in modern time can be worth his name without ability to think outside the box and be intelligent. His adoptive nature and flexibility helped him a lot in building his business. He is somebody who emphasized importance of time, he quipped 'time is money and I don't play with it'.

Just as efforts of individual entrepreneurs is important in creating entrepreneurship culture, environment in which entrepreneurship is natured is very important as well. In a period, nations states around the world are competing to create their national champions, Nigeria (an African giant) is left behind. According to Wikipedia "National champion is a governmental policy in which large organisations are expected not only to seek profit but also to 'advance the interests of the nation'; the government sets policies which favour these organisations.". Examples of national champions around the world are very easy to notice and they are as varied as the nations that produced them. For example, mentions the East Asian nation of South Korea and Samsung, LG, Hyundai, KIA come to mind; Names Brazil and Embraer, Petrobras, come as the nation's champions; India? You have Tata, Infosys, Wipro; Japan has Toyota, Honda, Sony; China on its own has Alibaba, Baidu, Haier, and Lenovo. Over the last two decades, economic power has shifted gradually from the so-called developed countries to what is now widely refers to as 'emerging economies'. Today's world second largest economy China was not long ago referred to as a third world nation. China was forecast to overtake the United States as the world biggest economy in no distant future. According to some estimates, it is already the world largest economy measured in term of purchasing power parity (PPP). The so-called BRICS, an acronyms coined by a former Goldman sachs executive to refer to Brazil, Russia, India, China, later joined by South Africa, demonstrated that shift in economic power from Western World to Asia and other emerging nations. Another group of emerging global players the next eleven ( $N-11)$, identified by the same Goldman Sachs executive Jim O'Neill, included Nigeria as a potential global player. How Nigerian authorities work to remain in the list is any one guess?

Dangote group of Companies employ thousands of people across Nigeria, imagine having five more Dangote-like organisation in Nigeria? How the fortune of the country will change and our unemployment menace reduce to the lowest limit possible? But, how Buhari create more of these big employers of labor? Shall Buhari just empower the rich by given them preferential treatments such as tax holidays, import quotas, subsidize foreign exchange, and government contracts, a big NO. Government shall create a level playing ground where potential entrepreneurs succeed. Favoring one business mogul at the expense of another only harms the larger economy, as previous experiences in this country and in others show. Favoritism poster corruption and inefficiency. A lot of those favor by, for example, Babangida military government failed to develop into employers of labour instead become crony entrepreneurs who helped in 
sabotaging government efforts to create a competitive environment. The same thing applied to Obasanjo efforts to create South Korea type Chaebol by means of selling government properties to friends and associates. The top global brands we have today started as national champions before graduating to global champions. Countries around the world have been supporting their own national companies to compete with those of other countries as far back as one can remember. The goal is the same whether in Europe, North America or Asia, the only difference is in methodology - the path followed in achieving the goal.

The US internet giant Google total market capitalization is bigger than many economies around the world, but it is still a private not government organisation. Other US giant companies such as General electric, Apple, General motors, Boeing, HP, and Walmart employ hundred thousands of people more than many nation states do. US internet heavy weight like Facebook, Google, Microsoft, Amazon, Yahoo, still lead the world in research and innovations while at the same time generating billions of dollars for their owners (shareholders) and the US government in form of tax. By creating our own Steve Jobs, Mark Zuckerberg, Bill Gates, Sergey Brin, Jeff Bezos, etc., Nigeria will not only create jobs and wealth but help build enduring institutions. America's Stanford, Carnegie Mellon, and Cornell Universities, were founded by wealthy citizens so are Ford, Rockefeller and MacArthur foundations. Private enterprise including small scale business is the most enduring way to create successful economy. The earlier Buhari economic managers understand this and start to put policies in-place for it realisation the better. Government agencies like CBN, ministries of finance, agriculture, commerce, labour, and mining must put heads together with other private sector actors to make this dream a reality. Smaller countries such as Singapore, UAE, and Taiwan have succeeded in creating their own champions, Nigeria shall learn from them as it moves to have its champions.

\section{$\underline{\text { Real estate business }}$}

I decided to explore the vast and unorganized real estate market of Nigeria after reading Robert Kiyosaki book 'Retiring young Retiring rich'. The market had continued to growth despite slow growth in Nigerian financial market. Nigerian economy had been one of the fastest growing in the world. It was ranked third fastest economy in the world. The continue grow in the economy had left people with liquidity they must invest somewhere. Looking at the slow recovery in the financial market after the global financial crisis of 2008, real estate was a safe investment. But unlike mortgage market in the United States, Nigeria real estate sector is not well connected to financial sector. The investable capital banks lend out to real estate sector is insignificant. As seen during past crises, the major contributing factor to Nigeria financial crisis was loans meant for purchases of shares (margin loan), credit extended to finance importation of refined petroleum by oil marketers (in short, bad loans to sectors other than the real estate sector), and poor corporate governance record of Nigerian banks. But, real estate came to the rescue of Nigerian investors, forcing price of assets down as a result of high liquidity. In developed countries, housing wealth constitutes about $70 \%$ of wealth, but the story is not the same in Nigeria. Nigerian 
housing sector has been neglected by successive governments. Private sector was not ready to tap the enormous wealth in the sector. At the centre of Nigeria's poor development of real estate sector are weak judicial system, absence of land right markets, lack of mortgage finance institutions, government neglect, and lack of awareness.

One factor mitigating against the development of real estate and mortgage financing is lack of land titles. Despite land reform act, a lot of land dealings were done outside of the formal channels. Government who is responsible for Issuing land titles to prospective land owners was left out in informal land transactions. That is why it was difficult to obtained loan from bank using land certificate from say, Bauchi or Sokoto. Most land certificates holders from Northern part of Nigeria with the exception of Abuja and parts of Kano and Kaduna found it difficult to get through with their application for bank loan. There are problems such as local farmland owners, like famers who cut their farm lands to pieces before selling to public. Most governments in the North are not doing enough to address this issue. Government aided the problem by slow development of town planning schemes as well as not making land title easy to get. In the south, only Port Harcourt and Lagos have successful medium to large real estate firms. In Lagos, real estate is one of the major movers of the economy of Lagos. It was easy to obtain a loan using land title from Lagos than anywhere in the country with the exception of Abuja. That explained the rate at which large scale commercial estate developers entered the Lagos market. Newly build estates are springing up in Lagos from areas of land used before as bush or farm land. Just like in other developed climes, Lagos state is reclaiming part of ocean to add to commercial areas such as Victoria Island. The scheme was estimated to cost billions of dollars. Name Eco Atlantic City, the hope of the developers is to develop it to be the new financial epicenter of the West African sub region with some of the tallest buildings one could find anywhere in Africa and beautiful streets. It is expected to provide accommodations and work space for millions of people.

There were few listed companies in the real estate business, the market is yet to take up looking at the potentials on the ground. Unlike in developed economies like US, UK or France where real estate market is an important segment of the real economy, Nigerian real estate market is under developed. Hence, it disconnection from the Nigerian financial industry. The housing deficit in Nigeria is huge, anyone who could invest tactically would make money. Governments at both state and federal level were not doing much to address the housing deficit. According to some estimates government would require a minimum of N60 trillion to provide 17 million new housing unit in order to addressed the deficit. This is to tell you how large the current deficit is and like many professionals have argued government alone cannot handle this without the involvement of private sector. Urban development is way back from what is obtained in other emerging markets such as China, Russia, Turkey or Brazil. Then, there is rural-urban migration that resulted in the migration of millions of youth from villages into town centers looking for job during dry seasons. Despite the problems, Nigeria is keen on attracting foreign investors into the sector. No single businessman from Nigeria richest men had not invested in the real estate sector of Nigeria, this is demonstration of the potential of the industry. The administration of president Buhari has invested billions of dollars in developing Nigerian infrastructures. The level of 
investment is unprecedented in the recent history of Nigeria. This alone is expected to boost the investment climate, particularly in the real estate sector. As Nigerian financial sector developed more money is expected to be invested in the real estate sector. Nigeria is projected by united nations to be the third populous nation in the world by year 2050, after India and China. This a lone is the reason global real estate actors have their eyes on Nigeria.

2016 was indeed a difficult moment for the Nigerian economy, share prices on the stock market had collapsed, both the inflation rate and interest rate were in double digit, value of Naira relative to the Dollar had fallen to an unprecedented level, price of crude oil (major Nigerian export) had remain where it was in the previous two years and above all the new APC government was fighting it out with different economic models not sure which one to adopt. And, the monetary and fiscal arms of the government behaved as if they were at logger head with one another. This climate of uncertainty made many investors skeptical of putting their money in Nigeria until when they were quite sure of the economic direction of Buhari government. But, another aspect of the economic crisis (which can be categorized as positive) is Nigerians in all spheres of life were looking inward (including those involve in the real estate sector) for made in Nigeria products and services. As a result of this renew vigor, real estate actors in Nigeria have started using locally produced raw materials for building of houses instead of the long overdued reliance on markets such as China's for doors, glasses, titles, electric wares, etc. This helped the economy in maintaining dwindling reserve of highly needed foreign exchange. But, taking into consideration the fact that both the real and monetary sectors of the economy were expected to move in unison, federal government must do more than it is currently doing through policy harmonization. There is no single Nigerian billionaire that is not investing in the real estate sector of the Nigerian economy in one way or the other, whether directly or indirectly. This tells you a lot about the potentials of the sector and how Nigerian Billionaires such as Dangote, Dantata, Adenuga, Isyaka Rabius, to mention just a few, are using the sector to diversify their investment holdings and hedge against risks.

Property developments in strategic locations around Nigeria are still going on despite the economic challenges, this tells much about how investors see the sector as promising with a lot of future potentials to turn the fortune of the Nigerian economy. In relation to this, some clever Nigerian investors have started purchasing real estate properties (at today's lower prices) keeping them for when the economy rebound, while others are investing in building commercial spaces including mega shopping malls. Unlike the developed markets, Nigerian real estate market is underdeveloped; this mean high expectation of returns from investments in the market, higher than obtainable elsewhere around the world. In Kano state for example, the state government has made it easy for land owners to acquire title to their properties at short period of time and at lower cost: around N5,000.00 in the lower income group. An innovative interest free mortgage system introduced by Islamic banks around the world provide an easy way for prospective home buyers to own homes. Nigeria first fully fledged Islamic bank Ja'iz Bank plc has been running Islamic mortgage scheme for the benefits of its clients for some time now. In Lagos, the Eko Atlantic city is one project that promised to revolutionize the real estate landscape of Lagos. 
Already work has reached advanced stage with some projects at near completion. According to the developers of the project, Eko Atlantic city promised luxuries obtainable in developed countries here in Nigeria.

Another important plus for the real estate sector is Buhari's government focus on building infrastructures with billions of Naira already allocated for roads, railways, bridges, electricity and airports. These are major components in the development of real estate sector in any economy around the world. Nation states such as Dubai, Singapore and even Hon Kong could not have made it without heavy investments in infrastructures. One trend worth mentioning here is how government policy forced wealthy Nigerians into investing in Nigerian real estate market instead of moving their investments to real estate properties of Dubai and London. As a result, thousands of jobs are being created weekly in the construction industry ranging from ordinary laborers work to production of doors, windows, painting, glass work, etc. The gradual restoration of security in Nigeria is another plus for the sector as it would go a long way in attracting foreign investors back to the sector. All Progressive Congress (APC) government promised to build thousands of houses across the country. Under another scheme, the Federal Civil Servants Housing Scheme (FISH), federal government promised to build 5,000 houses in each state of the federation for civil servants within three years of the lunch of the program. The program was launched in August of 2016. Federal government of Nigeria was trying to borrow from housing programs of Great Britain and Singapore who have (as their hallmark) uniformity of design throughout the duration of their respective housing programs. 


\section{CORRUPTION, INSECURITY AND CLIMATE CHANGE}

\section{Corruption and development}

To ordinary Nigerians on the street of Lagos, Enugu, Abuja or Kano the problem of Nigeria is nothing more than poor leadership. The medication according to most of these poor Nigerians is to change Nigerian leadership with new crops of leaders. Well, the practice of democracy in operation in Nigeria since 1999 has made that possible. Though, even this has its limitations, the electorate manipulations that characterized past Nigerian elections are one of such limitations. The Nigerian elites on their parts have blamed the Nigerian poor, global conspiracies, Nigeria complex geopolitical setting, and the size of Nigerian population for her poverty and underdevelopment. Nigerian problems have a long history of being linked to the ethnics and vast regions that made up Nigeria. In the last one decade, there have been calls for restructuring of Nigeria to conform with today realities of the country. The advocates of the restructuring, who are mostly from the Southern part of Nigeria, see the present structure as driving their region backward. Nigeria has about one fourth of African population most of them of economically active age but jobless. It was estimated that there are more than 53 internationally demanded mineral resources in Nigeria. These include gold, iron ore, coal, zinc, barites, tantalize, uranium to mention just a few. Nigeria is also endowed with fertile agricultural lands and millions of cattle. But, corruption has made the Nigerian elites to see Nigerian wealth as theirs to spend as they like. Over the years, billions of Dollars have been stolen from government treasury. Absence of achievable goals, poor coordination of activities between different segments of government, inconsistencies in planning and lack of continuity in capital projects have sabotaged Nigeria journey to development.

The word corruption itself is 14th century Latin word that came to English through French language. In Nigeria corruption mean different things to different people. Good terminologies have been used to replace the term corruption in order to suit dubious intentions of people. Examples include gift, commission, percentage, share, return, ratio, to mention the most widely use terms. There are various explanations regarding origin of corruption in Nigerian public service. Some scholars have concurred on period of British colonialism as beginning of corruption in public sector. Since, even Nigerian public service was creation of colonialists. The level of corruption in Nigerian public and private sector has contributed in giving Nigeria bad name. Rankings by transparency international, a global corruption watch dog, have consistently put 
Nigeria at the bottom of the index. Corruption has become a feature and sort of hallmark of Nigeria. Since returned to democracy in 1999 not much has changed from the corrupt culture left by the military. President Babangida left government at a time when corruption has already become the norm and it was from there that Abacha government took over and further made Nigerian situation worst. According to Lawal (2007), "Corruption is worse in countries where institutions, such as the legislature and the judiciary are weak, where rule of law and adherence to formal rules are not rigorously observed, where political patronage is standard practice, where the independence and professionalism of the public sector has been eroded and where civil society lacks the means to bring public pressure to bear". All the above listed features have manifested in Nigeria. It is not uncommon in Nigeria to see pensioners who put many years of work for the government begging on street, because their entitlements are yet to be released. The link between corruption and poverty can be observed here and not to talk of its connection to high crime one sees on streets of Nigeria. How do you expect rapid infrastructural development where contract for building of roads, supply of electric power, pipe born water, and airport is inflated from the actual amounts? The direct monetary implication of this is in billions of Naira, means to build three roads but only built one. This reduced rate of economic growth and development.

According to the late economic Guru, Professor Sam Aluko, there is a kind of positive correlation between corruption and amount of income earned by individuals in Nigeria. As it appeared the higher the income of a civil servant or politician, the more the amount of money he steals. Corruption also distribute income in favour of corrupt class who are already rich (Aluko, 2008). Thus, increasing the incidence of poverty and wealth disparities. Data released by National Bureau of Statistic shows percentage of people living in poverty has increased since returned to democracy to about $70 \%$ of the population. This underscored the increase of corruption in Nigeria despite return to civilian rule. In Northern Nigeria, corruption is an important explanatory variable in the high incidence of corruption in the region. Leaders with origin from the North ruled Nigeria for about $65 \%$ of its history but have not much to show in the development of the region. Even in Niger delta, despite trillions of Naira the region is collecting annually there is little sign of infrastructural development. Governors of the Niger Delta region are one of the most corrupt in Nigeria. Kidnapping for ransom is one of the major problems militating against the development of Nigerian regions and poverty and unemployment are some of the causes. Government officials tell the poor to sacrifice for betterment of Nigeria, for greener future while on their part they are not ready to forgo corrupt practices. In French Niger republic, despite poverty, level of corruption is not endemic like Nigeria. Hence, the argument linking Nigeria deteriorating case of corruption to legacy left by British.

In a paper on good governance Professor Sam Ejite O. (2007) categorized Nigeria problem of governance in four contexts; dictatorship and authoritarianism; weak constitutional institutions such as legislature, judiciary, and political parties; class character of the economy that allowed use of stolen money to acquire power; lastly, personal rule by those in power. Where judiciary is victim of executive dictatorship and political opposition is weak, not much should be expected in 
fighting of corruption. Nigerian judiciary behaves as if it is another executive arm. Any projection on future economic progress of Nigeria must take negative impact of corruption and bad governance into consideration. Otherwise, it will fail to arrive at realistic estimate of future growth and development of Nigeria. Corruption has become a kind of survival blood for Nigerian economic and political systems. Subtracts corruption, government and business cannot function effectively in Nigeria dominated by elites ruling Nigeria since independence. Ministers and directors, in typical Nigerian ministry, expect contractor to disclose their percentage earning in a yet to be awarded contract before assurance of getting the contract is given to him. A businessman lower quality of work awarded to him to maximize profit. A middle level government or business organisation employee expects job seekers to give bribe in return for handing over the appointment letters to their new jobs; or percentage of their first salary in the event applicant do not possess money. A university lecturer awards marks when given bribes or get connected to important people in government or business. A journalist expects a brown envelop to write a favourable story or cancel yet to be published negative story. An employee of a local government refuses to go to office until the end of the month when he is expecting his name to be included in monthly salary Boucher. A Nigerian religious leader surrenders neutrality and fear of God in order to be at the service of the powerful in exchange for share of an ill-gotten wealth. A typical Nigerian voter expects bribe before queueing in the sun to cast his vote.

The population of the poor in Nigeria has continued to increase, from some $60 \%$ in the last few years to around 65\% today. So is the number of billionaires, Aliko Dangote has witnessed multiplication in his total wealth putting him among riches individuals in the world. In the last few years the rich class has witnessed increase in wealth and welfare the result of favourable government policies, while the poor class has seen deterioration in general standard of living. This was not an accident as deliberate government policy that favoured the rich caused it. Look at the central economic issue of wealth distribution, it is still highly skewed in favour of few million Nigerians at the expense of over hundreds million people who are wallowing in abject poverty. I hope I am not sounding like a Marxist here. But, the truth must be told that poverty remain the major economic challenge for Nigerian governments. A situation where good jobs are reserve for only those that come from rich families, who have good connections, is disaster waiting to happen, in a country that want to reduce the high level of inequality in its mid. Despite continue promises to create jobs for the teaming unemployed youth, the government has failed to deliver on this key promise. Hence, the resort to criminal activities by these unemployed graduates, in form of kidnappings, robbery, email scams, petty thievery, and hooliganism. Abuja Nigeria capital has become a kind of magnet that attract the rich and throw away the poor. Why? Simply because life is so expensive in the capital city that only the super-rich can afford its luxury. The poor are literally restricted to rural areas and states capitals, living in overcrowded quarters and ghettos. For a first time visitor to the country who arrived Abuja and do not go outside of it to other states, that person would wrongly assume that Nigerians are rich. But, go outside the capital to any village in the country and you will see extreme poverty starring at you- welcome to Nigeria the country of rich and poor. 
Corruption was so endemic as habit and way of life of the Nigerian elite that mere thinking of somebody coming to power with the intention of fighting the menace of corruption made the elites shiver. With corruption Nigerian elite has found a powerful weapon to maintain the status quo, the suffering of the majority of Nigerian population under government induced poverty. There is no powerful weapon to perpetuate inequality more than corruption. The numerous efforts in the past by the Nigerian poor to put people with clean record into power was stalled by the corrupt elite by means of election rigging, another form of corruption. With Nigerian democracy as it is now, it will require extraordinary effort to bring a government that will fight for the interest of the majority. Globally, education has been recognized as a powerful weapon in reducing inequality and increasing societal welfare. But, one irony here is that Nigerian governments both, at federal and state levels, do not care much about education; since they have send their children abroad to countries where education is valued. Imagine having $70 \%$ of Nigerian population as literate and educated, do you foresee this kind of nonsense taking place. The answer is simple No. It is understandable when government is very serious with education, you can give it room for excuses (for example) on its lapses in other areas in the fight against inequality. But, a government that neglect the education of its people has no room for any excuse from the people it governs. Poverty, inequality, and illiteracy, the three evils that found a sanctuary in Nigeria and governments that lost clues on how to solve these problems are Nigeria main problems.

An average Nigerian elite do not like the word REVOLUTION, because by revolution it means the majority are going to remove the minority from their long overdue hold on power. It means the unexpected happening, it means change; and the rich and political class hate change. Every election year the two eminent political parties in Nigeria put things in place to see that they win the elections. But the question remain, is INEC ready to provide free and fair election? Looking back and taken the previous elections into consideration the answer is no, but one hopes this time around whoever is at the helm of affairs during the time will do miraculous things and provide acceptable election to the people of Nigeria. In his book 'Neo-Liberalism or Democracy?', Arthur MacEwan (p. 225) writes 'the problem of how to achieve democratic economic development is not nearly so simple as the numerous puzzles that Holmes attacked, nor are the problems of development ones that can be settled primarily by the clever reasoning of a sharp intellect. The barriers that block democratic economic development are social and political: they are problems of power.' I guess that explain our problem here - POWER, how could the majority lay their hands on power? I hear somebody mentioning election! But, big-time riggers are there to ensure that the poor did not realized his ambition of putting somebody clean into the position of power. With politically bias individual as heads of INEC, the dream of bringing clean, visionary, upright and intellectual to spearheaded the needed change is gone. What next for the poor is the question that sometimes give me restless nights.

In a report about Nigerian oil industry released by a Nuhu Ribadu committee on Nigerian oil industry sometime in 2013 commissioned by President Jonathan regime, Nigeria was said to have lost trillions of Naira to thievery by government officials in conjunction with international 
collaborators. But, the very government that set up the committee jettison it when it found out that the findings of the report were too much for it liken, as it touched many people connected to power at the time. Since return to democracy in 1999, Nigerian power sector has consumed trillions of Naira without improving national supply of light beyond the level left to civilian when military handed over power. The power sector together with oil sector is one of the biggest corruption corridors in Nigeria where corruption has become the order of the day. According to most estimates, Nigerian farmers account for about $70 \%$ of Nigerian population and contribute more than $40 \%$ to gross domestic products. But all these notwithstanding, the sector is the most neglected in Nigeria. On the state of infrastructures, the story is the same despite Nigeria being the biggest economy in Africa. Nigerian roads kill thousands annually because of lack of maintenance of existing ones and construction of new ones. There is no sign of such utilities as pipe born water, electric supply and good communication systems in most Nigerian villages. Therefore, leaving rural dwellers with no other option than to migrate to urban centres; thereby, causing congestion and overcrowding in places such as Lagos, Kano, Kaduna, Ibadan, and Enugu. An average rural dweller in a Nigerian village, whether it is located in Bayelsa in the Niger Delta, or Katsina in the far North, earns less than a \$1 dollar in a day; the equivalent of about N350 in Nigerian currency. Like all other segments of the Nigerian governance system, judiciary has been compromised due to greed of judges, and Nigerian mentality of 'let get rich quick'. Your chance of getting a fair hearing in Nigerian courts did not depend on how guilt-free you are, but how loaded with cash and connected to those in corridors of power. In such a scenario, it would be difficult to convince an average foreign investor to invest his hard earned capital in Nigeria comatose economy, without some sort of guarantee either from government, big private organisations or an external body. In some cases, it takes guarantee from all the three to secure investment in Nigeria chaotic business atmosphere.

Statistics coming from both Nigeria Bureau of statistics (NBS) and World Bank have shown incidence of poverty has increased in Nigeria, where as things stand now about sixty-five percent of the population are living below poverty line. This is happening despite the stupendous wealth Nigeria's elites continue amass. A visit to Abuja the nation seat of power is enough to demonstrate how the lucky few are living in luxury while the majority Nigerians wallow in abject poverty in the rural areas and far fringe parts of Nigeria. Graduate unemployment has been on the increase since returns to democracy, and despite, the fact that Nigeria has realized billions of Dollars from sells of crude oil in international market. In 2014 in Nairobi the capital of Kenya, Nigeria's richest man Aliko Dangote (during a visit of Nigerian delegates to the country that included President Jonathan) told gathering of diplomats and businessmen that he heard from an authoritative source that Nigeria was second largest market for private jets in the world. While rich Nigerians such as Dangote and co travelers were enjoying huge wealth, hundreds thousand were dying due to ill health, lack of clean water, and poor sanitary conditions. In Kano, Aliko Dangote home state, lack of electricity has put many industries out of business while millions of beggars were roaming the streets looking for charity. Nigerian media some time in 2013 carried stories of alleged federal government deal with a Dubai based luxury goods dealer to supply fifty- 
three Gold plated mobile phones to be given out as gifts to a select few Nigerian elites during Nigeria fifty-three independence anniversary. This happened under a President that said stealing was not corruption. Ex-president Goodluck Jonathan was generally seen as too weak to do anything about the corruption he met at assumption of power in 2010.

The rising tide of poverty in Nigeria's North East, as many analysts have argued, was the aftermath of poverty and central government neglect of the region. During my sojourns in the region between 2011 to 2014, I came face to face with abject poverty. Roads in the region were dead, schools dilapidated, industries non existing, health centres few and ill equipped, and street begging the order of the day. While the federal government in Abuja under then president Goodluck Jonathan was making noises about it non-existing achievements - being blown out of proportion by its propaganda machinery, a visit to social networking sites such as Facebook, was enough tell one how the government was condemned because of its inability to get the poor out of hardship they were enduring. In Nigeria oil rich Niger delta, billions of Naira has been squandered on an amnesty program for militant which ended up in pockets of few militants' leaders; who despite government gestures continued to steal government crude oil. In the South East kidnapping was the order of the day where many unemployed graduates engaged in the act in order to make quick money. Not surprisingly, the victims of all these kidnappings were the rich elites who after all were the ones who have stolen the money needed to provide these unemployed graduates with descent jobs - as the saying goes a child who stopped his mother from catching a sleep would not catch any sleep. In the South Western part of the country, arm robbers have terrorized communities killing and stolen people possessions a phenomenon which when look at critically was the same outcome that is common in a society where youth were not provided with jobs.

At level of state government, just like at federal level, corruption had eaten deep into day to day state governments activities. No contract was awarded without some percentage allocated to those who gave out the contract; this is apart from the usual inflation of contract and execution of substandard works. Since the return to civilian rule in 1999, the number of state governors accused of stealing their state treasury dry has increased. Cases such as that of Diepreye Alamayeiseigha in Bayelsa, Peter Odili, in Rivers, Saminu Turaki in Jigawa, James Ibori Delta are only the most prominent ones. It was alleged that departing state governors at the end of their final terms, did sell to the highest bidder the candidature ticket of state ruling party to the next coming executive governor in billions of Naira. Corrupt Nigerian governors aid corruption in any possible way they could. Ordinary Nigerians have not been left behind in sharing in the growing corruption monster. Nigerians be it tailors; radio repairers, bricklayers, or traders have created their own ingenious way of cheating others in any kind of transaction. A bricklayer knew how to reduce the quantity of cement in a particular mix in order to steal an extra bag of cement without the knowledge of his employer. A tailor reduced meters of cloth from the actual size he was asked to produce in order to use it for another purpose. A radio mechanic charged you for a supposed damage part of your radio, in which case he claimed to have replaced it with a new one; but, in reality nothing like that happened, he just wanted the extra money. A trader sells expired brands 
to his ignorant customers in order to make money quick. So from top to bottom the big monster in the way of Nigeria's progress is corruption. Corruption on the part of security personals is even worth. As it does not need any mentioning here that there are hundreds of thousands of security road blocks on Nigeria roads for collecting a minimum of fifty Naira from passing vehicles; this is unfortunate.

Some people were wondering whether billionaires like Alhaji Aliko Dangote (the owner of Dangote group of companies) were some kinds of cabinet members in every Nigerian government. His romance with governments depicted him as one of members of the executive teams. In 2014, in Kenya with former President Jonathan, Dangote showered all kinds of praises on the president; including associating his successes as businessman with Jonathan efforts to revamp Nigerian economy. Back in 2014, Immediately after signing a loan agreement (in Abuja) with Nigerians banks for financing of his refinery and fertilizer plants, Dangote headed to Jonathan office and did the same praise singing where as usual he attributed all his success to President Jonathan. The same year, he was in New York together with the inner cabinet members of Jonathan regime doing the same praise singing. Some would say that he was a member of Jonathan economic management team as justification for all he was doing as the image maker of the regime. But, many other people would not see it that way. What would come to many people minds was that as 2015 was fast approaching Jonathan used the successes of Dangote in building his huge business empires to realize his desire to get re-elected in 2015 general election. But, that is not where the real issue for Dangote lie, should Dangote mortgage his future and that of his empire for short term political gains even if it meant the regime won the re-election - it would only last for another four to eight years. But, ordinarily business empires such as that of Dangote should last for much longer than that - for decades or centuries. When Jonathan lost the election to opposition candidate Muhammadu Buhari in 2015, Dangote then changed tactics. Knowing that the new government was going to be different, Dangote adopted the strategy of tactical withdrawal from his previous position of an image maker of every government in power. The new government also did not engage him in her economic team like the previous government of Jonathan. Nevertheless, he still kept rapport with the government; because that was the only way to survive in Nigeria murky political environment.

In countries such as China, Russia or Egypt you could not make it as far as Dangote made it in Nigeria without belonging to the ruling party or being in their good book. In Russia you must be in the good book of Mr. Putin; but, come to think of it of Billionaire Bill Gate having to be in this kind of romance with Trump, Obama or any other US President for him to maintain his wealth. I am not here trying to exonerate the US system and its inherent weakness, but at least they were doing better than this. It is acceptable for businessmen to follow the President of their country when he is on mission abroad to generate business back into the country, but not with the kind of desperation I have seen in Nigeria. Dangote should remember that he was not like any ordinary developing country Billionaire, he was a global star and all the eyes of the world were on him. Activities such as the one he was involved with governments in power would cost him direly and affected his international image and money making potentials. In the run off to 2007 Presidential 
election, the then CEO of Nigerian stock exchange Mrs. Ndidi Okereke was involved in an embarrassing campaign mess; sourcing money (albeit illegally) to fund election of Obasanjo's preferred candidate, the late Umar Musa Yar'adua. It was this sort of corruption that slowed the efforts of African countries to sources foreign investments. In Africa, it is normal for a businessman to be in bed with every African government in power for him to be able to make money for his businesses. African nations such as Nigeria should at least have the courtesy to excuse business people with needed money and ideas from their dirty politicking.

Because of the recent importance professional economists have attached to corruption related matters, there is today a large body of literature on economics of corruption where corruption is rigorously study and analyzed. There is currently changes in academic scholarship from the era when economists saw corruption as a research topic for scholars of sociology and political sciences, to now when corruption is seen as very important in understanding the economies of developing countries of the world. There is no way one can understand economies such as that of Nigeria without delving into matters related to corruption. Recently in Nigeria, the most talk about issue was the new Whistle-blowing policy of President Buhari, the rate at which corrupt government officials were exposed on daily basis, more especially the amount of money being discovered was alarming. Since coming to office in 2015 President Buhari has made fighting of corruption the epicenter of his government activities. According to some government sources, Billions of Naira of stolen government fund have been recovered. But, of more immediate impact on people understanding of the government war against corruption is the whistle-blower policy which empowered citizens to report any case of corruption to secrete phone numbers operated by the federal ministry of finance, from where government officials would take the case and investigate. The campaign has helped in making government efforts to close leakages in its sources of revenue and ensure financial discipline. In just about four month of the start of the policy over 80 billion Naira of stolen money was found.

The cost of corruption to economic growth of developing countries is enormous. Due to externalities the cost of corruption to African economies is not easy to calculate. Corruption leads to inefficiency and low productivity. In Nigeria, poor government regulation, inefficient legal system and poorly trained law enforcement officers have contributed to corruption. In societies where the moral fabric is low and poverty is rampant, corruption is difficult to be defeated. There is wide spread believe that effective anti-corruption war spurs economic growth. The fight against graft in China, south Korea, Taiwan and Chile was instrumental in their economic successes. Nigerian government need to engage with its business community as they are very important in the present arrangement. It is a known fact that Nigerian business men have in the past collaborated with corrupt public officials to launder stolen money. Foreign investors are another important source of corruption, where they spread the ill practice from one country to another with the expertise of someone who has been in the business for a long time. But, government must be careful and very intelligent in its anti-corruption fight so as not to scare away foreign investors from coming into the country, as this will have an adverse effect on economic growth. For example, according to some analysts poorly executed war on corruption 
in China has caused the country loss of about $1.5 \%$ of gross domestic product (GDP). Here in Nigeria, the epicenter of corruption (in the entire Nigerian governance system) is the public service where enriching oneself from government funds is seen as the norm. How much Buhari war against corruption is contributing towards pulling Nigeria out of recession is not yet made public by federal government. But, figures from IMF and Nigerian Bureau of statistics show the economy is moving back to higher growth gradually.

Empirical evidences have shown a negative relationship between strong financial accountability and corruption. Transparency by government and good budget performance are good signs of strong governance culture. Sometime bureaucratic structure in public institution helped in fostering corruption. Considering the devastating impact corruption had on Nigerian economy, it is high time for Nigerian universities to introduce courses on Economics of corruption. This will help students of Economics, Business Management, Finance, and Accounting to know more about corruption. I can give an example here of what happened in the United States after the collapse of the Energy giant Enron, some business schools immediately started running courses on corruption related matters including students' visits to prisons in order to highlight to them the consequences of their future actions or in actions. In order to make the successes recorded by President Buhari anti-corruption efforts sustainable, government must introduce an effective Whistle-blower protection framework. This will go a long way in encouraging other people to come out and tells the true concerning the whereabouts of looted government funds. Buhari government shall rise up to the expectation and expose all past leaders who contributed in instilling Nigeria's notorious corruption culture as well as put things in place to cleanse the national assembly off rotten members in order to pave way for effective legislation against corruption. Someone has described the two chambers of the national assembly as 'chambers of corruption'. But, whatever policy Buhari put in place it shall be implemented carefully and intelligently, I will suggest that people shall be encouraged to vote-out the present governors, corrupt senators and members of house of assembly.

\section{$\underline{\text { Regional development }}$}

To philosophers such as Karl Marx and even to some extent Ibn Khaldun the process of history and politics, the dominant happenings in the world, were explained by one theme: material acquisition. To Karl Marx, the type of cloth we wear, the food we eat, our culture, religion, and politics are all influenced by economic factors. The Marxist theory of Dialectical materialism centred as it is on materialism and opposing social forces, associated changes in our society and history to these major worldly factors. The same thematic methodology is borrowed here to explain the situation Nigeria has found herself so as to properly position things in a right perspective. From issue of Boko Haram insurgency in the North, ethno-religious crisis in central Nigeria to Niger Delta militancy in coastal Nigeria, the single underlying cause is economic need of opposing sides. The corner of Nigeria from where Boko Haram originated is the poorest section of Nigeria, an underlying factor behind recurring crisis in central Nigeria is control of economic 
resources particularly land, while Niger Delta militancy, as the world knew, is on resources control - crude oil. Policy makers in Abuja (Nigerian capital) must come to the realization that the genesis of Boko Haram is economic problems and needs, that is poverty among the inhabitants of the lake Chad region, followed by a deadly ideology of a particular religious sect. The amnesty program in the Niger Delta region has to some extent reduced militancy but not eliminated it. But, as part of the underlying cause of the problem (and a consequence of it) youth unemployment and inequality remain.

The states of Borno, Yobe, and Adamawa are the poorest in Nigeria, according to national poverty indicators. Encroaching desert has made hundreds thousands of farmers to leave their farms while cattle herders migrated South for greener posture for their animals. Inside big cities such as Maiduguri, the capital of Borno state, the growing army of unemployed youth available for recruit by criminals was worrying. The fact that the region share border with impoverish parts of Niger, Chad, and Cameroon is a clear pointer to role played by poverty in putting the region in the mess it founds itself. Thus, it would seem naive or deliberate for anyone to dismiss the role of poverty in the rise of Boko Haram. The degree of inequality in Niger Delta and gap between oil barons and ordinary citizens is glaring. Hence, the haste by youth in the region to enter oil bunkering in order to make millions of Naira quickly. It was a known fact that some of the most expensive mansions in Abuja were owned by people from Niger Delta who equally own other choice properties in their region. But, enter their villages -the country side- there one sees people in suffering and crying of absence of amenities such as good roads. The main cause of crisis between so-called settlers and indigenes in the central Nigeria was control of resources such as land, business premises, farmlands, and grazing grounds. It becomes clear and more pronounced in recent years because of poverty; and youth are out of jobs.

The above factors defined the scenario in Nigeria and were at play for a number of years before now. Problems such as absence of regular electric light, scarcity of farm employments, and other categories of jobs, deteriorating security situation and crimes, and poor condition of health institutions have combined to make things difficult for ordinary Nigerians. In an environment where free and fair elections are possible, it is easier for citizens to make their choices and vote those that can salvage them from bondage. But, in the absence of such environment citizens would be left in confusion and loss of confidence in Democracy and its ability to bring desire changes. Hence, the need for building effective media and civil society organizations as watch dog; who put government back on track whenever its goes astray. But, where media (the so-called fourth estate) and civil society are bought out by political class and big corporations, ordinary man confidence in the ability of civil institutions and with it democracy to provide for him the minimum standard of welfare will nosedive, leaving him at mercy of any alternative ideology even if it were Utopian in its doctrines. The poor man doesn't care since it is a matter of survival, and those that are supposed to care for him have abandoned him for nature to take it cause. This is the peril and risk to government that abandon its people and a system that is so corrupted that leaders can do whatever they want and no one will hold them responsible. 
The rich become richer and the poor poorer! The rate at which poverty is growing in Nigeria has upped in recent years. This made commentators to wonder whether government care for a moment about consequences of widening gap between haves and have nots. But, for observers of happenings in Nigeria, reason for governments lack of concern is not difficult to fathom. An important weapon by which the poor can punished any government in power for its actions or otherwise -democratic election- has been abused and twisted to favour corrupt elites in power. It is even surprising in a country that claim to be conducting free and fair elections, that despite election government did not care about the dire condition majority of voters were in. This tells you that elections in Nigeria were being rigged all this while. While this was happening some radical elements in different regions of Nigeria were taking advantage of the situation to advertise dangerous ideologies to gullible public, majority of whom were poor left abandoned by a careless government. Thus, Nigeria is a country of extremes: a government composed of unsympathetic capitalist class on one hand and growing number of religious and ethnic extremists on the other hand. It is the innocent poor that is left in the middle, while radical elements are doing all they can to recruit him the government don't seem to care for him. It is, therefore, easy to see why people are being recruited into the hands of these religious and tribal radicals like Boko Haram.

As Nigeria marches toward becoming an important economy in the world, issue of how to tackle poverty and the widening gap between rich and poor will continue to pop up. We wait to see whether Nigeria will become India or Brazil of Africa or both. Where in the case of India you have extreme poverty going side by side with rapid economic growth, while in the case of Brazil you encounter a peculiar case of inequality going together with economic growth. But, despite the poverty of India and inequality of Brazil their democratic systems seem to be working better than Nigeria's, increasingly given hope to the poor in those countries. Unlike Nigerian case where democratic transition has been punctuated by election rigging and poor governance. Nigerian economy would be better with free and fair elections as well as good governance. But, where none of these exist then there is trouble and less hope for the majority poor. It is, therefore, up to Nigerian elite to see that they provide these things. But, the success recorded during the 2015 elections has given hope to the poor, that his voice can be heard and he could change an incompetent government when he so wishes. In a world where protest has become normal and toppling of government by ordinary citizens on the street has become common, it is in the interest of Nigerian government to ensure that it listen to its people. Otherwise, what happened in Ukraine and North Africa in the last decade would come to Nigeria. Remember that the only constant thing in this world is change, therefore anything is possible including change to Nigeria corrupt elitism.

In 2008 Soludo, the central bank governor at the time, made a statement to the effect that Northern Nigeria poverty level was dragging Nigeria and, in particular, the Southern part of the country backward. He further added that if not for Northern poverty, Southern part of Nigeria would have become a developed region/country, according to his own reasoning. At that time many people wrote rejoinders, some confirming the existence of poverty in the North, while 
many others went ahead to tell Soludo that though there was Northern poverty, Soludo was going out of his way to politicized the issue, to score political gains. Therefore, like at that time, Nigerian poverty issue has two realities; one, it is beyond any doubt that Northern part of the country is ravaged by poverty; two, Southern politicians and technocrats were trying to score some political advantages out of the issue. I was opportune to listen to a BBC Hausa special program in the recent past, on an annual poverty figures released by National Bureau of Statistics (NBS) at that time. The program anchor had invited Dr. Hussaini Abdu of ActionAid Nigeria and Professor Chika Aliyu of Usman Dan Fodio University Sokoto Nigeria to discuss the NBS data. While Dr. Abdu was of the view that the data was objective as it reflected the reality on the ground, Professor Chika disagreed with him, saying there was always politics in the kind of data generated by NBS. Particularly, Chika drew attention to the fact that majority of the staffs of the agency were from one part of Nigeria and the method employed in generating data in the North could not capture the reality on ground. Though, I didn't agree with all the arguments put forward by professor Chika on the issue; but I quite affirmed that there was politics in the data the same way other governments around the world politicized their data to reflect how their leaders want to see the world.

Speeches and utterances of the then CBN governor, Sanusi Lamido Sanusi, about revenue allocation and poverty had generated its own debates and controversies like that of his predecessor in that chair. While Soludo is a Southerner, Sanusi is a Northerner, so you can see how each part of Nigeria made their statements at different times and observed how contrasting their opinions were. While Northerners were of the opinion that revenue sharing formula, as Sanusi also observed, was not favourable to the North; the Northern elites were to be blamed for the Northern poverty not any individual outside the region. In a region endowed with different types of mineral resources and agricultural potentiality one wonder how people of the place wallowed in poverty the way poor Northern peasant did. If the North of the 1960s did not depend on Southern part of the country despite constraints imposed by knowledge and technology of that period of time, I wonder why the North of $21^{\text {st }}$ century would do that? One should not forget that despite oil resources in Nigeria, about $40 \%$ of GDP is generated by agricultural sector mostly contributed by Northern part of the country. But, why should a state like Zamfara with hundreds of rich mineral resources that include Gold, Tantalize, and Iron failed to develop them instead preferring to stay in poverty? Is there justification for Kano state with second biggest economic and commercial potential after Lagos to prefer to depend on federal (monthly) allocation? People tended to argue that Northern poverty was because Northerners were not in power in Abuja between 1999 to 2015, forgetting the fact that when Northerners were holding power at the center they did not do much to assist the region growing poor class, except for their selves, families and cronies.

What are the ways out of Nigerian poverty problems? First of all, Northern Nigerian has to look inward rather than outward in order to get solution to it problems. The time of blaming somebody else for Northern problems is over, unless the North don't want to get to the root of its problems and attend to them. While rich Northern elites like IBB, Abdusalamu and Atiku 
preferred calling for meeting and conference to discuss Northern problem, the like of Danjuma, and Dangote opted for setting up foundations to assist those in need and create jobs. The second is the best option, rather than calling for tea parties the recommendations of which were never implemented, the elites should do something real for the Northern peasant. One of the globally recognized development instruments that help the poor is microfinance banking, the system channel capital to entrepreneurial individuals among the poor who otherwise could not get loan from commercial banks due to absence of collateral. Alas, there are few microfinance institutions in the North, and how many did the like of IBB and Atiku established to assist the poor people in Minna and Yola. Education remain one of the insurmountable problems of the North, with many of its people not having access to Western education despite the billions said to have been spent on the sector. In a country where public schools were allowed to die and decayed, anything is possible including recruitment of unqualified teachers to teach the children of the poor. Why should farming died, the way it did? If Northern governors were to provide their poor farmers with assurance of a market for at least one cash crop in each state, the scheme would be able to cut Northern poverty to half. Because, it would put money in their pockets; like groundnut, cotton and hide and skin did in 1960s. Nobody should just say it is not possible, because countries of the EU and the US spend Billions of dollars annually to subsidize their farmers who are rich enough already. The efforts made by the government of President Buhari in rejuvenating the agricultural sector is commendable here. Due to this phenomenal event, the number of rural dwellers coming to the cities has reduced, because they are now preoccupied with farm activities. Rural poverty is also climbing down, as the market price of agricultural commodities in Nigeria make it profitable to farm. Unlike few years ago when imported food items have driven most of the farmers out of farming.

In the major indicators of human development, North East Nigeria rated worst. Some of the most poverty stricken states in Nigeria are concentrated in the region, in addition to being incubating ground of Boko Haram's insurgency activities. The biggest city in the region, and its commercial nerve centre, Maiduguri has since lost it vibrancy and dynamisms to place such as Gombe. Maiduguri that had some of the richest people from the region and known for its peace and accommodation of strangers has since lost that. Thousands of people have migrated elsewhere where there is calm and siren atmosphere for business to prosper. What remained of Maiduguri is a shadow of its former self. The same, to a lesser extent, is true with other major towns in the region such as Bauchi and Yola ravaged by the same security threats. Boko Haram is a product of poverty, but the question is who are to blame. Is federal government the only party to take the blame? The North East region was left at the mercy of poor masses and street beggars. Let compare some figures, in term of number of universities the North East has the least number when compare with other two regions in the North, that is North West and North Central. But, even the North West only compared a little better than the North East. Tertiary health facilities (Teaching hospitals), North East (3), North West (3), and North Central (4). In term of industries, the region also lagged behind, despite the abundant mineral resources of the region. The region also has the worst federal roads of any part of Nigeria. 
Like most major Northern towns before advent of Boko Haram crisis, Maiduguri remaining industries have collapsed leaving in their trails shadow of their former selves. The aftermath of this on economy of the state has led to loss of thousands of jobs and investments worth billions of Naira. Now that the crisis has finished what remain of the few skeleton industries and business in once vibrant capital, what is next for the government? The odious atmosphere of war has a killing effect on business continuity; forcing those business that insisted on leaving their doors open to work below capacity. Foreign workers such as European, Indians, and Chinese were hunt and killed during the height of Boko Haram crisis, deterioration in infrastructures that these people helped to build is going into a new low. This helped to destroy the economy and scared away foreign investment for development of the region. Lagos street in Maiduguri was one of the most popular locations in the state capital because of its shops that sell all kinds of things particularly to the middle class and rich. But, the devastating impact of Boko Haram crisis could be seen glaringly by any one that cares to go there. Southern Borno, an area mostly populated by non-Kanuri (Kanuri are majority ethnic group in Borno state) and that shares border with Gombe and Adamawa states, in all my sojourns around Nigeria I had never came across an area with so much bad roads. Couple with the mountainous geography of the area and absence of industries the place was one of the most difficult to live in, poverty stare at you as you enter its hilly vicinities. The near collapse of education in the whole of Borno state was painful. The sight of burn schools was very common in rural parts of the state during the height of insurgency. Borno state government was overstretched as it shared its meager budget between restoring peace and government functions such as education and building of roads. In education, burning of public schools by Boko Haram made it difficult for the state government to pull the sector out of years of decay and low productivity.

One remembers how peaceful Borno and Plateau states were, they were proclaimed centres of peace and tourism. Surprisingly enough, the two states were the most volatile in Northern Nigeria due to crisis. Peace refused to reign, killing of people and destruction of properties has become the order of the day. The famous palace of Shehu El-Kanemi in the heart of Borno, and great Lake Chad in the north have attracted thousands of tourists from in and outside Nigeria, generating millions of Naira in the process and creating jobs for others. But, that has become history, no tourist come to a place where he became a target of killing. A place where light-skin foreigners are hunted and killed for no other crime than they were in a place where they were not wanted. As a result of these, the state has lost millions of Naira annually in the form of revenue. When Obasanjo and later Yar' adua were awarding contracts for conversion of Kano to Maiduguri highway into a dual express way, one of the justifications they gave for awarding the contract was that it could serve as part of the much larger trans-Sahara road linkages between West, North, and Central Africa. Maiduguri has (since time immemorial) being the door that link traders from lands north of Lake Chad which is today occupied by Chad and Niger republics (and North Arabian countries) and Southern part of the lake occupied by Nigeria, on the other hand.

In agriculture, the hallmark of president Jonathan agricultural transformation was commercialization. His government, through his minister of agriculture Dr. Akinwumi now 
president of African development bank, has put priority on large scale commercial agriculture. But, while it was doing so it deemphasized small scale rural farmers in favour of large scale investors such as Dangote. In all the countries that agriculture have help transformed their economies by providing revenue and most needed employment, small scale farmers were the center of the transformation. Most of the noise governments at various level were making about agricultural transformation were only on paper as the real farmers in various rural locations around Nigeria did not know much about these agricultural transformations. Fertilizer was still difficult for ordinary farmers to get, farm credit was not available, and modern farming equipment obsolete. The much talk about creation of jobs in agriculture and related services was nowhere near becoming true. But, all these change when Buhari came to power in 2015 . He too initially met with challenges, but because his government was more serious about agriculture than Jonathan, he later overcome most of these challenges. First, both small scale farmers and commercial farmers such as Dangote were priorities at the same time. Through government large scale fertilizer program, rural farmers were provided with enough fertilizer at affordable prices. Loans were also provided for people to go into farming. Commercial farmers such as Dangote were given incentives through credits and the mother of all the 'banning of importation of agriculture outputs'. Nigerians were forced to patronized domestically produced rice leading to reduction in importation of rice by about $95 \%$. Nigeria is about to become self-sufficient in food production and start to export to other countries.

Before, the poor budgetary allocation to agriculture was not only peculiar with the federal government, as most state governments have continued with their neglect of the sector. If not with the coming to power of Buhari regime, importation of food stuffs into Nigeria did not change. Nigeria was one of the largest importers of rice in the world, among other agricultural products. About $90 \%$ of Nigerian farmers still depend on ordinary farm implements such as hoe to produce the food they need to take care of their families. Hence, the predominance of poverty among Nigerian rural dwellers who are mostly farmers. Therefore, agricultural revolution that focus on Billionaire farmers, did little to reduce the cycle of poverty that was ravaging rural farmers. Instead, it paved way for the much bigger revolution that swept away Jonathan government from power in 2015. While in many countries around the world agriculture is held in esteem and protected like the defense sector, the reverse was the case in Nigeria. Successive administrations have neglected the sector focusing instead on how to spend the easy money coming from oil. In what is believed to be oil curse Nigerian government inclusive of its people had become lazy who blinded themselves to opportunities that existed around them. Not far from Nigeria, South Africa the second largest economy in Africa, earns substantial amount of its foreign exchange earnings from agriculture, despite the fact that they are the largest producer of Gold in the world. Economies like Argentina, Brazil, Holland, Thailand to mention just a few, still depend to a larger extent on agriculture. With population of over 190 million people, I do not know of any country with the size of Nigeria's population that neglected agriculture. With population of this size, Nigeria's preoccupation should have been not only to feed the people but how to export the excess being produced so as to make the people (majority of whom are 
farmers) occupied and from there earn foreign exchange from exports. Nigerian agriculture still produces about $40 \%$ of Nigeria gross domestic product (GDP), but failed to get less than half of the number from annual budget allocations.

\section{Effect of insecurity on development}

The nineteen states that made up the old Northern Nigeria have confronted challenges right after Nigerian civil war, from problems of poverty, insufficient funds in government coffers, youth unemployment, lack of infrastructures, moral break down, death of businesses to the mother of all insecurity. The peaceful North of yesterday has today become synonyms with insecurity; the simple way of living and social cohesion the North was known for have all gone. The booming business and industrial atmosphere of Kano and Kaduna were replaced by states of abandonment and economic uncertainty. In Maiduguri business life had been shorten, human live had become worthless, many industrial plants were deserted, workers became refugees, employers of labour become spectators, poverty and penury the order of the day. Due to Boko Haram, the North Eastern city of Damaturu had become a ghost town where location after location were being deserted by people to be occupied by lizards and other reptiles, a sort of Grozny of Nigeria. Inside Damaturu workers and traders ran for dear live to avoid becoming victims of clash between security forces and Boko Haram. In North Central, Kogi state became a battle field where gunshot sounds became so common, fear had taken the place of trust, neighbour spy on neighbour, and sense of abandonment took over. The Nigerian capital Abuja was not spare either, it got its own share of the bombers vengeance. The police headquarters and United Nation building bombing were two prominent examples of how insecurity had penetrated the hitherto relative peace of the Nigerian capital.

How could one expected oil explorers in a desert corner of Borno state to resume exploration when there was no guarantee of security for their lives? The same thing applied to Indians and Chinese doing businesses in Kano and elsewhere in the North. Decline in industrial output of industries in Kano and Kaduna, though this has been going on before the inset of the insecurity, has contributed to the increase in unemployment. The first thing visitors to Kano or Kaduna noticed was mammoth crowd of queuing cars and motor bikes at check points across roads and corners of these cities. This served as red signal to potential investors of the uncertainties of these places. At markets in Kano the complains one overheard from traders were on the falling numbers of businessmen coming to Kano from other states and neighboring countries. The presence of military personnel with sophisticated weaponry told one of an atmosphere of war. On indices for measuring human welfare, the North lagged behind the South, and the coming of insecurity made matters worse. Education sector was crippled; students were scared to go to schools. Markets became no go area because of the fear of the unknown, people preferred the safety of their homes. Even rural farmers found it difficult to move farm harvest to markets in cities for fear of Boko Haram bombs. The North had beaten the South in violence and threats to live without beaten it in term of economic growth and development. 
Nigeria was not the only country in the world facing serious internal security challenges. other nations threaten by insecurity includes Indonesia, Russia, Ukraine, Mexico, Pakistan, India and even China had all faced one insurgency challenge or the other. While these countries faced the situation head on proffering formidable approaches to deal with the situation, Nigeria was lost in defining the problem. Because of that billions of Dollars were squandered between 20112015 without attending to the root cause of the problem. While, for example, in Pakistan authorities had evolved religious, ideological, and socio-economic ways of dealing with their situation, in Nigeria the authorities were thinking along the line of using military forces to crush the insurgency. The use of brutal force has never solved any security problem to the satisfaction of warring parties; at most, it can only succeed in minimizing the problem but not eliminating it all together. In the recent years, top global military spenders in term of defense budgets in billion dollars were United State, China, Russia, United Kingdom, Saudi Arabia, India and France. For decades now the US share of this annual monetary spending is more than that of all the next five nations combine. Nigeria annual defense spending was not near that of African countries such as Egypt, Algeria and South Africa. Boko Haram had become a thorn in government's throat. The security personals were overstretched, working in different theaters of war and communal violence around Nigeria. The government of Mr. Jonathan had failed to solve these security riddles, despite huge annual security expenditure (including special extra-budgetary allocations). But, the fact that monetary allocation was not indicator of measuring success of his government policy on security, the huge allocations had done little to bring peace. In the opinion of military turned politicians such as late General Azazi, insertion of zoning clause (between North and South) in the constitution of People Democratic Party was responsible for Boko Haram violence. It was Johnnie Carson, former US assistant secretary of state, who was quoted to have said the problem of security challenges in the Northern part of Nigeria was because of economic factors and not necessarily politics and religion.

Like the Americans had observed, I believed solution to security challenges facing the North could be found in poverty ravaging the region. Instead of allocating Billions of dollars to security federal government should use part of the money to address economic problems of the North. The Americans even suggested to Jonathan government the creation of ministry of Northern affairs like its counterpart the ministry of Niger Delta. But because people in Jonathan administration did not like the idea, they forwarded different conspiracy theories to explain American government reluctance to support Jonathan government endorsed hypothesis about genesis of the crisis. Looking at the annual money allocated for security matters, Nigeria should rethink its national security strategy. Like with other countries facing security challenges, Nigeria should start developing its domestic defense industry. Countries such as China, Pakistan, Iran, Brazil, Turkey and South Africa have their own defense manufacturing firms. Pakistan has developed her domestic defense industry to the extent it is exporting some defense wares to other countries. Pakistan assembles a range of defense products that includes warplanes, war tanks, missiles, drones and even submarines. South Africa exports war tanks, helicopters, military vehicles, and other security wares. 
In the past, America annual budget deficits and domestic economic challenges were caused by over bloated defense expenditures. Since September 11 attacks, United States has spent trillions of Dollars in wars outside US land. The US is a net borrower from the rest of the world because it could not control its security budget. Nigerian government cannot afford to go the United States way. First, economic fortunes of the two countries are not the same, America is a rich developed country, Nigeria a poor developing nation. Looking at the poor infrastructures in Nigeria, allocating a quarter of annual budget to security did not make economic sense provided there were alternatives to tackling the security challenge. In certain economic circumstances, deficit budgeting was not desirable, especially for a country not in war. Pakistan domestic economy and global competitiveness has been seriously affected because of involvement in wars, billions of dollars in GDP has been lost. The economies of Syria, Ukraine, Sudan, Mali, Afghanistan, Congo and South Sudan have all felt the impacts of wars. Dialogue not war is the answer, economic progress is only attainable in atmosphere of peace. The problems of insecurity and unemployment have so far beaten all the narrow solutions put forward by past Nigerian governments. Boko Haram that originated from the state of Borno in the North East has spread into other parts of Nigeria like wild fire, causing damages and destructions to people and properties. Now that most of the insurgency activities of Boko Haram has been subdued, Nigerian government must put credible plan on the ground to prevent the reoccurrence of this catastrophic event that cost Nigeria thousands of lives and billions of Dollars in GDP.

The solutions to these challenges can be found both in short term policies mean to ameliorate the situation and long term plan that serve as lasting solution. A hungry man is an angry man, so the saying goes; according to estimates about $70 \%$ of Nigerians live below poverty line. Number of unemployed roaming streets of Nigeria is in millions. Thus, it is not difficult to figure out connection between insecurity and unemployment. In the past, Jonathan's advisers had fed the former president with a theory that the increase in violence was because Jonathan came from Niger Delta. Understanding the genesis of the violence had become complicated for comprehension of Jonathan security team, apart from the naïve hypothesis that the insurgency was due to Jonathan coming from Niger Delta region which had never produced Nigerian president before Jonathan. The failure of Jonathan regime to understand socio-religious and economic causes of the insecurity was at the heart of his government failure to find solution to the menace. North East is the poorest part of Nigeria, filled with hopeless and poverty stricken people who had little or no hope in governments both at state and federal level. The number of jobless and tugs roaming the streets was high. Thus, youth recruited by Boko Haram needed little persuasion to join the group. The job of dealing with Boko Haram should not be left in the hand of people who were only competent in gathering military intelligence forgetting the other intelligence that was necessary to solving the security challenge. The problem of joblessness has become endemic that need special intelligence to solve. But, politicians were not ready for that they were only thinking of immediate solution before the next general election came. Hence, the failure of the use of military force to solve the menace by President Jonathan. But, the problem of Boko Haram was older than Jonathan regime. It first showed its ugly head during the time of 
President Obasanjo, then came all out with all its forces during the time of late President Umar Musa Yar'adua.

Like in similar places around the world, Nigerian government must be serious about youth unemployment if it wants to get it acts right. Problem of poverty in parts of Nigeria has being the source of much disaffection among ethnic groups. kidnapping people for money that has become notorious business in South East and North Central parts of the country has its roots in unemployment in the regions, likewise the case of oil theft in Niger Delta. The period when government appointments to sensitive ministries were based on political considerations or region a candidate came from is over. Appointment as ministers of economy, employment, defense, work and housing and trade and investment shall be made on merit. Nigeria as the most populous country in Africa and its biggest economy, must follow in the example of China and become self-sufficient in most of its agricultural and industrial needs. On issue of Boko Haram, dialogue, orientation and job creation remain the only options for solving the problem. Now that prospects of oil discovery in Lake Chad, Sokoto basin and other areas of the North has increased, case for the economy of the North become stronger. Already there were strong indication of deposits of crude oil in Borno, Bauchi, Gombe, Kogi, Niger and Kwara states. I hope things will turn out right for the sake of Nigerian unity; and, those looking at other regions as parasite will have to look for other excuses. The oil money, like in the case of Niger Delta, should be used to develop infrastructures in the North, to make the poor North catch up with the South. One important area governments in the North need to pay attention to is in generation of internal revenue. In Nigeria, people are aware of the amount of money Lagos state is generating from internal revenue sources. Lagos state has achieved self-sufficiency in revenue generation when compared to other states, to the extent that the amount it is generating from internally generated revenue (IGR) is more than what it is collecting from federal government. Northern states with internal revenue generation potentials include Kano, Kaduna, Sokoto, Kwara, Niger, Borno, and Gombe states.

\section{Climate change and development}

The word 'trouble' is no stranger to Nigerians; in fact, it is one of the many words used by millions of mouths every day, whether in Lagos or Kano, Port Harcourt or Kaduna. In many of these occasions, the word is used to refer to conditions like poverty, insecurity, election rigging, Nigerian banking mess, and Nigerian economic conundrum, but little is said regarding Nigerian climate problems. Reason for this might not be unconnected with the devastating imprint poverty has made on Nigerians minds. Government on her part has little in-store for climate problems. The money accruing to government was used to settle other problems not necessarily more important than climate problems. But, the damages our attitude to climate is causing Nigeria is enough for government policy makers especially economists and environmentalists to reconsider government stand on the issue. The lake Chad region whose inhabitant has bear the brunt of Boko Haram over the last one decade is a good example of the negative effect of climate 
change on Nigerian security and socioeconomic settings. The torrential rainfall that caused serious damages to Nigerians houses, roads and places of work bear the footprint of climate change. In recent years, Nigeria two major rivers (Niger and Benue) and their tributaries have over flooded their banks causing damages to the neighbouring environments.

At regular intervals, global gathering of environmentalists, investors, energy experts, economists, and scientists converged at venues around the world to brain storm on climate change. Past venues include, Montreal, Kyoto, Cancun, Doha, Copenhagen and Paris. Major issue at stake has remained climate change - its impacts, economics, and politics. Minor world gatherings and pact signing events were also staged in the past. The Kyoto protocol was adopted at the Earth Summit of 1992 in Rio de Janeiro (Brazil), otherwise known as United Nations Framework Convention on Climate Change, and before that there was the Montreal (Canada) protocol of 1987 designed to prevent the use of ozone-depleting gasses. Another gathering took place in Cancun (Mexico) a familiar location for global gatherings. As it was expected nothing concrete came out of the Copenhagen, but disagreements and the endless blame games and finger pointing, particularly between world two major emitters, the United States and China. There were big differences between developing and developed countries centered on climate economics. The developing countries saw it as responsibility of rich countries to cut emissions and pay cost of preventing climate change. Rich countries were responsible for over 200 years of carbon emission. Rich countries, on the other hand, have accused poor countries of massive deforestations, environmentally harmful agricultural practices, and use of old manufacturing plants known for their excessive emissions of $\mathrm{CO} 2$.

Nigeria has one of the most complex scenarios of any developing nation. With population of over 190 million people, about 65\% living below poverty line, big environmental disaster will have catastrophic impact. Nigerian leadership has to look more critically at climate change. Take for instance the fast approaching desert in the North, it has already tempered with socio-economic setting of people living there. Desertification is an important cause of poverty in the North. With about $70 \%$ of Nigerians depending on farming, anything that affect farming increases poverty. Then excessive heat, temperature in Illela town, Sokoto state is as intolerable as in desert with water being a scares commodity there. Illela is a local government headquarters with bank branches, custom and immigration bases. Despite low rainfalls and decreasing crop yield, Illela inhabitants continued to farm. The practice continued, year in year out, despite the obvious. Due to the environmental hazard caused by climate change half of new seeds planted ended up burnt by drought and excessive heat. The same excessive heat is found in Sokoto, Katsina, Damaturu and Maiduguri all state capitals in the North. One sad development about Heat and desertification in the North is that only few states know how to approach the problem. There is now annual ceremony of lunching tree planting campaigns, accompanied by the usual empty promises of planting hundred thousands of trees. Cases of diseases outbreak in the North have their root in climate problem. The last outbreak of cholera in North east killed hundreds of people. Difficult economic condition help in heightens cholera spread. Due to harsh rural 
environment only few qualified medical personals live in local government areas. As a result, vicious circle of poverty-diseases-desert encroachment has re enforced one another.

Across the river Niger, to the southern part of Nigeria, they have their own peculiar difficulties when it comes to environment. Apart from Oil spillage and deforestation (for urbanization purposes and uses by logging industry) in Niger Delta and other coastal states, there is flooding due to overflowing of rivers and ocean. The economic consequences of these are enormous taking into account important contributions coastal communities are making to Nigerian economy. Just imagine how much it will cost to reclaim portions of areas taken over by sea water due to increase in ocean water. It runs into billions of Dollars. Though this is a distance possibility, but with climate change anything is possible. What roles should Nigeria play in the global efforts to tackle climate change? As a poor developing country, Nigeria cannot adopt, for example, some of the approaches proposed by rich nations. It was suggested that countries should stop using old industrial machineries that produced large quantities of Carbon Dioxide. With use of advanced technologies, rich countries can afford to substitute high carbon emission machines for low carbon emission ones. After all they have the financial muscle to organize space missions. Although developed nations are moving away from high carbon manufacturing, Nigeria cannot phase out her high carbon emission plants at once. Taking this path will mean stopping production of cements, oil productions in the Niger Delta, thermal power plants, and industries in Lagos and Kano. This has the immediate effect of slowing down GDP growth, increase unemployment in the industries affected, reduction in power generated by environmentally harmful power plants, high inflation and reduce inflow of foreign direct investment. Thus, just like big energy consumers such as China and India kicked against the approach, energy hungry economy like that of Nigeria will also force Nigeria authorities to resist the plan.

Programs to help climate change initiatives in developing countries are many. Number one for immediate implementation in Northern Nigeria is tree planting. It is argued that if poor countries cannot cut on their $\mathrm{CO} 2$ emission, they can, in the alternative, contribute by planting trees that absorbs $\mathrm{CO} 2$ away from the atmosphere. Apart from the immediate benefits of stopping desertification, beautification of environment, and provision of food, it has long to medium term effects of reducing global heat and increasing rainfall. The cost of this program compared to benefits to be derived is insignificant. Apart from other surmountable obstacles to this campaign, the main threat to tree planting is corruption. With a leadership eager to steal, anything is sacrifice-able. Previous studies on economics of corruption in Nigeria have found corruption to be an important obstacle to realization of Nigeria's economic targets. Nigerians living in cities still use firewood for domestic cooking. Hence, the desirability of sensitization and provision of alternatives to fire wood with introduction of energy efficient cooking methods. That is where Nongovernmental organizations and energy research centers come in. In the past, Sokoto Energy Research Centre of Usman Dan Fodio University Sokoto and other government own research institutes around Nigeria were in the forefront of the campaign for use of energy saving cooking stoves. A handful number of NGOs are also campaigning on the same issue. In other locations around the world, Nonprofit Green organizations are in forefront of reforestation 
campaigns. These NGOs, for example, provided money to pay local communities for planting of trees or for not cutting existing ones. Nigeria does not have to wait for foreign governments or donor agencies to pay her villagers for planting of trees. Neither should Nigeria wait for corrupt bureaucrats; her wealthy billionaires can fill the gap. The Dangotes, Otudolas, Dantatas, Adenugas, Jimoh Ibrahims, Isiyaka Rabius, to mention some of the most well-known rich families who can help with money to pay villagers employed in tree planting functions. Private sector companies should, as part of corporate social responsibility, contribute to the project. 


\section{WOMEN IN GOVERNMENT AND BUSINESS}

Role of Women in Development

In my assessment of roles and contributions of Nigerian women to Nigerian economy in the last one and a half decades, I will start with Dr. Ngozi Okonjo-Iweala. A former supervising minister of economy and two-time finance minister, foreign affairs minister, former director of the World Bank and member of boards of many international organisations. She has PhD from MIT, Bachelor degree from Harvard University and decades of work experience with World Bank. She is unique in the league of Nigeria professional women, being the first female minister of finance and the most powerful female minster in Nigerian history. Her last post before she left World Bank for a ministerial appointment in Jonathan government in 2011 was Managing Director of the bank in charge of South and East Asia, Europe and Africa where she controlled portfolio worth $\$ 81$ billion. She first served as finance minister during second tenure of President Obasanjo in 2003, helping his government to secure debt relief for Nigeria of \$18 billion from Western creditors. As finance minister under Obasanjo she relentlessly pursued policy of reducing bureaucracy and trimming of government budgets. In 2012, she contested for the office of the President of World Bank where she lost to a powerful US candidate, Jim Yong Kim. It was argued that unlike during her first appointment as a minister, Mrs. Okonjo-Iweala as minister of finance under Jonathan did not do much to stop corruption going on under her purview. As the saying goes, if you can beat them join them, it seemed like Dr. Ngozi become tied of opposing corrupt bureaucrat and finally join the party or rather become indifferent to it. Her tireless war, during her first ministerial appointment to instill transparency in governmental activities, had banished when she came back in 2011. Dr. Ngozi initiated Nigeria into the global transparency body (Extractive Industries Transparency Initiative- a voluntary standard for petroleum and mining industries worldwide) when she served in Obasanjo government 2003-2006. But, those who appreciated what Ngozi Okonjo-Iweala has done see things otherwise. Supporters see Dr. Ngozi differently, she came with an outsized public profile with appointments coming from international organisations. Like the Managing Director of International Monetary Fund (IMF) Christine Lagarde who herself was a former finance minister of France and an acquaintance of Ngozi, she had aspired to become President of World Bank based on her past track record as a technocrat with many years of experience working for World Bank and as a former finance and foreign affairs minister. She brought about some level of discipline to Nigeria unruly finance 
ministry. It was also to her credit that Ngozi helped to fight the old bureaucracy that had bedeviled the ministry for many years.

Journalists and other outside observers, see Dr. Ngozi as schemer who hide behind an artificial innocence pasture to entrench dictatorship. She was accused of connivance in firing of an employee of a federal government parastatal for writing an article critical of her role in appointment of the boss of Federal Inland Revenue Service, back when she was minister of finance. The rumored story of her interest to contest for president of Nigeria was in the Nigerian news media twice. It first surfaced when Obasanjo transferred her from ministry of finance to foreign affairs ministry, to get acquainted with rudiments of international diplomacy and get the backing of international community. The rumor fizzled out immediately she resigned from her appointment and went abroad. A Book by Mallam Nasiru El-Rufai (a minister in Obasanjo government 2003-2007) titled, 'Accidental Public Servant' further lent credence to her rumoured interest in politics. The book made mention of Obasanjo plan to field her as running mate with Muhammadu Buhari in the 2007 Presidential election. Many Nigerians see Dr. Ngozi as agent of Western capitalist interests, especially the World Bank and IMF. As technocrat who spent her working live in the world Bank, holding sensitive posts, she could be linked with efforts by Western institutions to impose their socio-economic agenda on Nigeria. A Distinguish fellow of Brooking Institution, a leading Western think thank base in Washington DC., Ngozi, whose father was a Nigeria base university professor of statistics, ought to have convinced Nigerians she was not protecting interests of capitalist institutions in Nigeria. To Nigerian labour unions, her controversial endorsement of fuel subsidy removal in January 2012 further added to her image as propagator of World Bank-IMF beggar thy neighbor economic policies that advocate implementation of harsh economic policies on poor Nigerians. In deviation from earlier promise made during confirmation as minister in 2011 where Dr. Ngozi affirmed her resolve to reduce federal government recurrent expenditure (which was then at $74 \%$ of budget), Dr. Ngozi failed to deliver on that promise, budget-after-budget. Though, in books he has written after leaving government, she accused Nigerian state governors for causing that. Recurrent expenditure aspect of federal government budget had remained high throughout her second stint as finance minister, leaving little for capital expenditures.

As top world bank staff, Ngozi had not done much to champion the cause of African countries or development economics, where critics argued her employer (the World Bank) has done little to address the burning issues there. If not for the last two decades' changes in policy, programs of the bank had focused on given loan to countries to finance building of white elephant projects that did little to help the situation of the poor. It was in the last two decades that the bank began to move its focus from the financing of huge budget projects to soft issues like micro financing, HIV/AIDs, and provision of direct supports to the poor. But, Ngozi as someone who had spent all her working career in the World Bank under the same working culture and leadership, her critics argued was least qualified to tackle such problems in other appointments. But, Ngozi advantage in aspiring for the bank top job include the fact that she herself came from a poor country and continent with millions of poor families in need of assistance, and her work experience as finance 
minister of Nigeria afforded her opportunities to work directly in a poverty ravage country. Though, Ngozi first stint as finance minister did little to address the plight of Nigerian poor, she has done other things indirectly to help the poor like her initiating of programs to generate jobs and fight poverty. Mainstream economic and finance newspapers such as The Economist, Financial times of London and New York Times have endorsed Dr. Ngozi during her candidacy for World Bank top job, but this is another pointer to her sympathy for liberal economic policies. The fact that these papers are hardline neo-liberal capitalists and advocates of text book economic prescriptions of the neo classical school of thought, explained their support for her candidacy. Hence, some critics points in arguing that her world views championed the status core. There is this hypothesis that females are less corrupt compare to their male counterpart and the fact that women and children made up the largest share of the world poor was seen as plus to her candidacy. But, whatever way one looks at her as a well-known female public figure, her CV is big with excellent educational qualifications and work experiences.

Mrs. Ndidi Okereke Onyiuke is a former president of Nigeria Stock Exchange where she held enormous power as the President of the NSE during the presidency of Obasanjo. She was at then seen as an iron lady of the Nigerian stock exchange who many men feared and respect. She has a huge bodily frame like many other rich (powerful) women in Africa. Ndidi ranked in the clique of women holding important public position in Nigeria, during her tenure as head of NSE. Her tenure at the helm of affairs in Nigerian stock exchange started smoothly at the beginning of the tenure. But, it was later clouded by intrigues and controversies that were to characterize her final years as the head of the exchange. It was widely said of her in the Nigerian media that she was such a power monger woman that she controlled not only the Nigerian stock exchange but the supervising agency of the Nigerian stock exchange, the SEC. The Security and Exchange Commission (SEC) head (named Musa Al Faki) was said to be appointed at the instance of Mrs. Ndi Okereke; hence, her subsequent control of SEC. One of the controversies that would later sink the career of Mrs. Ndi was the controversial raising of funds for election campaigns of a PDP presidential candidate. Many Nigerians (at the time) accused her of delving into issue that was not her business at the expense of her official assignments in order to get favours from the Presidency. In the process of these funds raisings jamborees, she used her influence in the exchange to ask for contributions from major companies and actors in the Nigerian private sector. Her fund raising jamborees took place on about two occasions, during general elections to support the candidates of the ruling party. She also engaged in fund raising for the reelection campaign of US President Barack Obama, but his campaign office later denounced her. Unlike business executives holding similar position in other places who eschewed politics, Mrs. Ndi wanted to have political relevance at all cost including at cost of dragging the exchange and herself into Nigeria murky political waters. At the end he paid the price of her naked desire for power and visibility, he was sacked from the office by another lady who was the new head of Security and exchange commission. She was later accused of falsifying documents related to her education in the US and on her other claims of working at the New York stock exchange. Like other Nigerian elites, Ndidi was busy chasing awards and honorary titles, he was honored with 
professorship of entrepreneurship by University of Nigeria Nsukka and there were other traditional titles there were bestowed on her.

Ndi Okereke started working with the Nigerian stock exchange back in January 1983 during the civilian regime of Alhaji Shehu Shagari and some 17 years later she rose in rank to become the chief executive officer of the exchange during another civilian regime this time around of Olusegun Obasanjo. At the time she was appointed the head of the exchange she was fifty years old, an age that one can say she was at her prime and full of energy to spear headed the needed reforms in the exchange. The controversies that followed the issue of dishonesty and falsifications regarding her academic qualifications and work experiences in the US would later damage her reputation and public image. As condemnations came from all quarters, Nigerians asked the authorities concern to make sure they made a thorough investigation on individual candidate before appointing him/her to the highest position in the exchange. Another controversial issue that Mrs. Ndi was involved in was the Transcorp PLC shares purchase dilemma. Transcorp is a conglomerate created at the instance of the former President Obasanjo who wanted to create South Korea type Chaebol Companies in Nigeria. Transcorp had acquired $75 \%$ of the shares of former National Telecom company NITEL. She was quizzed by EFCC because of the $\$ 750$ million accusation of NITEL by Transcorp where she was the chairman. EFCC also quizzed her on her controversial raising of N100 million for Obama campaign; and when it was time for her to response to the arm loads of criticism against her, she quipped "I want to make it clear that I am a Nigerian and I have the right to do anything I want with my time and my money". Under her management, the exchange reached the highest peak in its history and not long after sink to its lowest point. The spectacular rise in the fortune of the exchange was associated with (1) the growth in the Nigerian economy (partly contributed to by the increased in price of crude oil in the international market), (2) reforms introduced during her period (3) activities of speculators who were allowed to have their field days. Among the reforms introduced by the big Madam of the exchange were computerizations of the activities of the exchange, introduction of the All Shares Index, as well as her efforts at initiating the authorize clerkship examinations for those working in the capital market.

Amina Muhammed is Deputy Secretary of the United Nations Secretary General base in New York. Her role involves handling administrative responsibilities of the Secretary-General, helping to manage Secretariat operations, and ensure coherence of activities and programs. Before that, she was a minister of environment in the cabinet of President Muhammed Buhari from 20152017. Amina Mohammed was, before her appointment as minister, a key player in the Post-2015 development process, serving as the Special Adviser to UN Secretary-General Ban Ki-moon on Post-2015 development planning. She was prominent in her roles as government adviser, contributing immensely to the activities of humanitarian agencies in Nigeria. She also studied abroad in Italy where she studied hotel catering management. Because she was not involved with prominent governmental functions before her appointment as minister and the fact that she was not linked with many controversial issues not much was reported about her in the media. But, her position as top UN official has really put the spotlight on Nigerian women. Amina Mohammed 
was born in Gombe State, North-Eastern Nigeria. Her father was a veterinarian from Gombe state while her mother is a British nurse. Mohammed served as Founder and CEO of Center for Development Policy Solutions. She was an Adjunct Professor for the Master's in Development Practice program at Columbia University United States. She acted as the Senior Special Assistant to President Good Luck Jonathan on the Millennium Development Goals. She served about four Nigerian presidents in top positions. In 2005, she was charged, in collaboration with Dr. Ngozi Okonjo-Iweala, with the responsibility of coordination of Nigeria's debt relief funds as part of MDGs. Between 2002-2005, Mohammed coordinated the Task Force on Gender and Education for the UN Millennium Project. Mohammed has recently criticized the government that she served as minister between 2015-2017, blaming the government for Nigeria's rising debt profile. In 2017, Amina Mohammed was accused of taking part in a Chinese scam to illegally import endangered Nigerian rosewood during her term as Nigeria's environment minister. Though, the federal government has come to her defense by denying these claims. Those critical of her chameleon-like nature, accused her of serving under all kinds of governments, including those governments accused by international community of perpetuating huge corruption while in power.

\section{Women and Corruption}

In Nigeria where corruption has been endemic for decades, blamed for Nigeria present state of poverty and underdevelopment, one may be curious to know the part played by Nigerian women. Men have dominated Nigeria public and private corporations. In this, men might like to mirror their own images in the women they wanted to work with. Hence, one should not put much expectation in wanting to see Nigerian women casting a different image from that of their dominant male counterparts. In Nigeria, just like in many parts of the world, corruption is mainly associated with men who for centuries dominated leadership in government and business. In decades since Nigeria's independence, all the most serious cases of corruption were associated with men holding political and business positions. Reasons for this include the insignificant number of women holding important positions, long period of military dictatorship, high percentage of illiterates among women and of course the predominance of poverty within the vast population of Nigerian women. But, transition to democracy in 1999 seem to have changed things a little bit. Since the end of military rule in 1999, Nigeria has sizeable number of women in important positions; both in government and private sector. There have been four finance ministers who were women, female head of Nigerian stock exchange, petroleum minister, head of security and exchange commission, education, aviation and information ministers, chief judge of the federation, deputy governors, ambassadors, award winning authors, chief executive of banks, senators, just to mention a few. Worldwide, there is some level of agreement that the long held belief that an increased participation of women in government reduced corruption do not hold, indicating corruption is gender neutral. From 1999 to date, for example, a woman chief executive officer of one of Nigeria top banks was prosecuted for perpetuating corrupt practices 
in the bank she was leading. Female federal government ministers were also investigated in corruption cases. First ladies, who as wives of presidents, were also linked with many corrupt cases and abuse of power.

Debate about corruption among Nigerian women has become prominent in a period when notable cases of corruption among Nigerian women have become apparent. The case of purchase of two luxurious cars worth hundreds of millions of Naira by former aviation minister Stella Oduah had taken many unaware, that a female minister would have shown this senseless level of corruption that in the past was only associated with her male counterparts. The allegation against the minister did not stop there, there was the issue of bias and nepotism displayed by the minister in granting international airlines licenses to operate in Nigerian airports. Where she openly (without equity or decency) favoured her own people at the detriment of others. In locations where realities of commercial operation dictated that airlines should be landing due to size of these markets, she refused them landing rights; instead, directed them to airports in her geopolitical zone. Then, there was the case of granting of import waivers (worth Trillions of Naira by former supervising minister of economy Dr. Ngozi Okonjo-Iweala) to super rich Nigerians with connections at the top of the federal government hierarchy. Another female minister accused of corruption was the influential minister of petroleum Diezani Allison Madueke, under Jonathan government. Nigerian National Petroleum Corporation (NNPC) under her ministry was accused by former Central Bank governor Sanusi Lamido Sanusi of complicity in the disappearance of some $\$ 20$ billion. There was also the case of oil thefts that were going on under the watch of her ministry. Recently, Kemi Adeosun the Minister of finance under President Buhari was accused of providing fake National Youth Service Corp (NYSC) exemption certificate during her nomination as minister. Another former minister of finance, Mrs. Nnenadi Usman was asked to return money in relation to former national security adviser Sambo Dasuki notorious case of diverting some \$2 billion meant for war against Boko Haram into the presidential campaign funds of President Jonathan in 2015.

The life of many Nigerian women is horrendous, full of risks, poverty and ups and downs. An average Nigerian woman suffers for most of her live under hardship. Nigerian woman goes through all kind of obstacles to realise her dreams in men dominated ruthless Nigeria. Despite all the dangers involved in human trafficking (including ending up in prostitution and slavery abroad), the women involved in the business were happy with the kind of money they were making. As the saying goes, the end justifies the means, these women did not care about illegality of the business in as much as they realise their worldly ambitions or reach the top of their careers. Nigerian women need to act quickly to avoid a new corruption stigma from being placed on them by their men counterpart, who after all want the continuation of the status quo. Or it would look like the saying that 'if you can't beat them join them', some Nigerian women have joined the corruption league where their male counterparts dominated. This is even more interesting because Nigerian women were perceived to be weak and under domination of men. Typical Nigerian woman in rural areas suffered years of neglect by her husband who abandoned her and run to the cities in search of modern live. Nigerian authorities must do more to help the Nigerian 
woman situation by putting the enabling environment that allow women to reach the top of their career through lawful means without compromising integrity. The link between corruption and poverty is very strong, women and children are at the receiving end of the poor state of the Nigerian economy. At times, even the corrupt women at the top were forced into the situation they found themselves. Generally, only few women can rise up to the challenge and be bold enough to confront their male counterparts. Many studies have shown that most of the less corrupt countries in the world are also the most gender friendly countries in the world. Hence, the need to continue to fight corruption while at the same time respecting the rights of women and children. Creating the enabling environment for business to prosper is one of the important ingredients that can help to empower Nigerians women. Nigerian women are very enterprises and hardworking. They played important role in the development of small and medium scale enterprise in Nigeria by serving as the bulk of the small scale business manpower. Government shall make finance available for them to be able to finance their business ventures.

Not long ago, Ndidi Okereke as head of Nigerian stock exchange (NSE) had to manipulate the then SEC DG Musa Alfaki; while as finance minister Ngozi Okonjo-Iweala tried the same trick on former SEC DG Ms. Aruma Ote, that was what Nigerian media reported. Years later, another woman Kemi Adeosun, who was finance minister under Buhari, also manipulated SEC. All the three women mentioned have one thing in common, powerful men behind them. This is the case of Politics meeting corruption! Since the return to democracy in 1999, SEC has never been out of controversy despite its importance as the regulator of Nigerian capital market. Nigerian stock exchange, considering its importance as the gateway through which foreign investors invest their money in Nigerian economy, received the news of these debacles negatively. Commentators have linked the sacking of Mallam Munir Gwarzo as director general of security and exchange commission to nepotism, the need for the region where Adeosun came from to protect its own company, the Oando Nigeria Plc. Gwarzo has presided over a period with some level of reforms aim at returning the institution back to its core mandate. But, the corruption charges against Gwarzo if proven will damage his argument that he was targeted by the minister for not doing her bidding. If Gwarzo was merely using the Oando issue to hide his own corrupt involvement, an impartial investigation would prove that at the end and he should be punished according to the law. If the minister of finance was found to have taken side in this matter as alleged in some quarters, Buhari should also punish her or else the general public would see it as if Buhari was protecting his appointees. Nigerian women on their part blamed the Nigerian media that is under men domination for being bias against women. This is especially true in the few cases where women hold powerful positions that men see as preserved for them. For example, women hold other ministerial positions, served as head of government parastatals and permanent secretaries, but the attention of the media only focus on women who hold powerful positions like minister of finance, foreign affairs, education, aviation, petroleum, DG SEC, DG NSE, and so on. 
Women and Entrepreneurship:

Nigerian women like counterparts in other countries around the world have shown different level of desire and commitment, and eagerness to contribute to the development of their societies in any way they can. History is full of Nigerian women who excelled in various endeavors, despite the dominance of menfolk in all areas of human endeavors. Entrepreneurship as risky and innovative activities confronted women with special challenges. Traditionally, women are used to working in less risky and rudimentary working environments. Domestic works that women specialised in do not involve high risks, capital investments and much creativity. That notwithstanding, Nigerian women have at various times venture into businesses whether directly or indirectly. Because of that women are very prominent in the small and medium scale business sector. But, the lack of mobility due to the domestication of women and the low returns that come from most of the businesses that women are involved with hampered their abilities to grow and become big entrepreneurs. To challenge domestic poverty and be financially independent, Nigerian women have engaged in various kind of small and medium scale businesses from commercial food making, taxi business, retailing, tailoring, to beverage making. But unlike men, women are confronted by low level of education, lack of capital, poor representation and sociocultural challenges. The various programs by Nigerian government to develop entrepreneurship cannot progress without taking women need into consideration, since they made up large segment of the small scale enterprises. Nigerian government shall increase the percentage of female enrolled in formal education, this will enable them to have the basic knowledge required to run a modern business enterprise. Government must make its agencies and various institutions to be sympathetic to women causes. Thus, a positive discrimination that favours women is a good measure that will help empowered women. States and local governments shall emphasis provision of trade capital to women for them to be able to setup their own businesses. Nigerian women typically use their wealth to clothe, feed, educate their immediate and extended families, and transform their communities through social contributions. Women entrepreneurs can help in accelerating Nigeria developmental ambitions. Hence, any development agenda proposed by Nigerian government that failed to carry women along will fail.

In a paper on gender inequality in Nigeria by Golit and Adesanya (2013), the authors found that gender inequality in education depresses real productivity. The distortion caused by gender inequality in education adversely impact on productivity of workforce, reduce profit, investment rates and output. They recommended the implementation of deliberate policies to improve female participation in economic activities besides strengthening the policy on affirmative action for women in Nigeria. Academic studies have shown that intentions to begin a business enterprises increase with participation in entrepreneurship education (Honig, 2004). Entrepreneurship education and training in Nigeria has continued to receive attention from both 
the policy makers and the academia. The number of Nigerian universities that are running entrepreneurship training has increased. This may not be unrelated to federal government efforts through the national universities commission directive that all universities in Nigeria must offer entrepreneurship courses to their students. This goes in line with the adage that managers are made not born. It will help in building the next generation of Nigerian entrepreneurs, including women entrepreneurs. The richest African woman is a Nigerian entrepreneur Folorunso Alakija who earned most of her wealth through investments in the oil sector. She is involved in fashion, oil and gas, and printing businesses. She has been the managing director of The Rose of Sharon Group which consists of The Rose of Sharon Prints \& Promotions Limited and Digital Reality Prints Limited. She also served as the executive vice-chairman of Famfa Oil Limited. During her early schooling, she studied both in the UK and Nigeria. She loves fashion, having studied fashion design at the American College, London and the Central School of Fashion. She went on to establish her own fashion firm called Supreme Stitches, after working for Sijuade Enterprises and former First National Bank of Chicago, later called FinBank Nigeria. In 1993 she went into oil business by applying for exploration licenses, thus establishing the company Famfa Oil. Another Nigerian entrepreneur is Stella Okoli who made her money in the pharmaceutical industry of Nigeria. She is the founder and CEO of Emzor Pharmaceutical Industries Limited. The company has produced over 30 drugs consumed by millions in Nigeria and other African countries. The company is well known in Nigeria with over 33 years in the business of drugs making. Others include Amina Temitope Ajayi who is well known for promoting women empowerment and poverty eradication in Africa through Agri-business. She conducted her businesses between Nigeria and the United States. 


\section{ECONOMICS EDUCATION, MEDIA AND MODERN TECHNOLOGY}

\section{Economics Education}

Economics as a discipline has pass a threshold in term of accomplishments, rigor and richness. It is widely seen as father of social sciences. Of course, Economics is the only social science course that is recognized by Nobel prize foundation with an annual prize for the most outstanding economists who contributed to the development of the discipline. But, in term of modernization and professionalism, teaching of Economics in Nigerian universities have not witnessed work place adaptation and dynamism compared to rivals such as Business Administration and Accounting, who after all are offshoots of Economics that developed into independent disciplines about a century and a half ago. Business Administration has transformed into money making machine for Nigerian schools who run Masters of Business Administration (MBA) that attracts professionals with deep pocket such as bankers, employees of multinational organisations and tax collectors. Though, many people continued to rush for MBAs their corresponding value in term of type of job they could get applicant into is fast declining. The explanation for this is not far fetch, the standard under which these courses were offered did not meet international standards, sometimes. Thus, as schools compromised standard in order to make more money from big pocket students; they ended up producing graduates who fall below employers' expectations. The rush to offer professional courses has affected the ability of these university departments (in term of resources and manpower) to offer regular courses such B.sc and M.sc further eroding the general standard of university education. In economics department itself, professional courses such masters of banking and finance are encroaching on regular academic programs due to lack of academic staffs.

There are over hundred Nigerian universities (both private and public own), located across the six geopolitical zones of Nigeria, substantial number located in the South. The number of universities offering economics numbered more than $50 \%$ of the total because of popularity of economics and demand for it in labour market. University of Ibadan (which happen to be the first university in Nigeria) boasts of oldest department of economics in Nigeria. Nigeria main center for economic research (equivalent of America's NBER) is based in University of Ibadan, likewise Nigerian Economic Society (mirrored after the American Economic Association). Other universities established after University of Ibadan such as Ahmadu Bello University, Zaria, University of Nigeria Nsukka, University of Lagos, and Obafemi Awolowo University, Ife, had 
established their own economics departments that were to play prominent role in producing early generation of Nigerian economists. But, that is where it stopped, Nigerian economists and economic departments in its universities were shadow of their former selves. In 1960s and 70s economic departments of Nigerian universities were known for producing critical thinkers and scholars who contributed to formulating government policies. They also played important roles among global community of academic economists. Economists trained in Nigerian universities have gone on to teach in other African countries helping the development of these nations. Nigeria trained economists have also taught in other universities around the world.

Most of the prominent players in formulation of Nigeria economic policies were locally trained. This tells much about how good these departments were during the 1960s, 70s and 80s when graduates of Nigerian universities were in demand around the world. Professors left their chairs in Europe to come to Nigeria and take teaching appointments. Economists produced during those years include the like of Prof. Charles Soludo former CBN governor (UNN), former CBN governor Sanusi L. Sanusi (ABU), ex-minister of national planning Shamsudden Usman ( $A B U)$, Mansur Mukhtar former finance minister ( $A B U)$, former Managing Director of United Bank for Africa Toney Elumelu (Lagos), to mentioned only the key players in government and business. One reason for apparent decline in status of economics departments of Nigerian universities was absence of quality staffs in teaching and research. This like in other departments was contributed to by brain drains in which good university professors with publications in world renown academic journals had gone abroad where there are better conditions for teaching and research. Those that could not move abroad had moved their services to corporate sector and top administrative appointment in government where there was better pay and working condition. The good professors that remain have divided attention between teaching and consultancy works. Thus, the one factor that pays the price was no other than the quality of graduates produced by these institutions.

Some of the world acclaimed economic departments such as Massachusetts institute of technology (MIT), Cambridge, Harvard, London school of economics, Oxford and Chicago boast of not only a number of Nobel laureates but an alumni base that has defined the course of economics over the last century. In addition, they have contributed to development of the World economy. In these schools, the quality of teaching materials is superb, libraries and research centres the best in the world. No wonder every aspiring economist wanted to go there to pursue his academic interests. Their academic staffs have contributed to some of the best known Economic journals in the World such as Review of Economics and Statistics, Econometrica, Journal of political economy, Journal of monetary Economics, American Economic review, and Economic Letters. They not only contributed to shaping curricula of economics around the World but defined its future direction. They adapted technological changes as they appeared and helped defined its contributions to business and economy; something you could not say of Nigerian schools' economic departments. They supported promising students who showed academic excellence with scholarship to further their studies something you hardly see in Nigeria. Some of the graduates produced in Nigeria ended up pursuing careers different from the 
economic training they received at school. But, recent interventions by TETFUND is turning the tide positively in favour of Nigerian university with billions of Naira distributed among universities for building of infrastructures and training of manpower. Infrastructures in Nigerian university are gradually moving towards the standard in other top universities around the emerging economies of the world.

There was little contact between students and lecturers apart from meetings for class lectures. This did not help development of students into critical thinkers. Students were left with option of mastery of lecture handouts, a kind of garbage-in-garbage out (a world of crammers). This was contrary to what obtained elsewhere, where apart from regular class meetings professors gave students individual attention discussing economic matters with them and even helping them to publish papers early in their careers. In his autobiography after he received the Nobel Prize in Economics in 1992, the American economist Gary Becker described how department atmosphere was at Chicago where they were taught by great economists like Milton Friedman, Gregg Lewis, and T. Schultz. On Friedman, Becker has this to say, "He emphasized that economic theory was not a game played by clever academicians, but was a powerful tool to analyze the real world. His course was filled with insights both into the structure of economic theory and its application to practical and significant questions. That course and subsequent contacts with Friedman had a profound effect on the direction taken by my research."

Going back to 1930s, the department of economics at Harvard university comprised of some of the world greatest economist under one roof. These included Joseph Schumpeter, Alvin Hansen, Seymour Harris, Edward Chamberlin, Edward Mason, and Wassily Leontief who on their part helped inspired students that would later become world renown such as Paul Samuelson, Lloyd Metzler, Paul Sweezy, Kenneth Galbraith, Abram Bergson, James Tobin, Richard Musgrave, Richard Gilbert, Lloyd Reynolds, John P. Miller, and Richard Goodwin. Across Atlantic Ocean in London school of economics (of the same period of time) the economic department comprised academic staffs that included John R. Hicks, Lionel Robbins, Friedrich von Hayek, Roy Allen, Nicholas Kaldor, Abba Lerner and Richard Sayers. Thus, at the centre of success of any economic department is composition of lecturers who shall be brilliant, hardworking, versatile, and motivated to contribute to development of the department, giving their one hundred percent to research and teaching. In Nigeria, few departments comprise of world renown professors recognized in their fields, majority of lecturers were new PhDs and those pursuing PhDs. Though, this state of affairs is gradually improving with increase funding of universities coming from TETFUND. The recruitment process in some of Nigerian economic departments have become skewed due to nepotism. In the cases where merit was followed, the newly recruited staffs started looking for greener posture elsewhere immediately they got what they wanted.

Nigerian university economics curriculum needs to be changed to reflect changing realities of modern world. In Nigeria changes were not easy to introduce, interest groups do everything possible to frustrate such efforts. Scholars and policy makers have emphasized introduction of courses that encouraged free thinking and creativity. Existing curriculum sticks to old syllabus 
that emphasized mastery of old theories, the only thing that matter was certificate received at graduation. Mediocre lecturers were to blame for these scenarios, they used straight jacket marking scheme that did not allow for student's contributions and creativity. Such lecturers gave marks strictly according to lecture handouts. This contributed to the muddled atmosphere where graduates were not able to conduct research of their own but resort to stealing other ideas and works. After graduation, students found it difficult to contribute through freethinking and innovation to develop their places of work, what in reality Economics shall be. Although, economics is a quantitative subject one would be surprised to find out economic students dreaded mathematics and statistics, considering them as obstacles on the road to graduation.

But, the death of research culture was not only restricted to students, lecturers themselves found it difficult to conduct researches. In cases where they wrote papers, the papers ended up been published in departmental journals of lower quality than international journals. Then there was proliferation of private journals who accepted all kind of paper in as much as authors paid publication fees. Though, the problem was not restricted to Nigeria, that did not mean Nigerian academics should accept it. Though, not all fee paying journals were of low quality, there were many who did not deserve the name academic journal. A publication of Nigerian Economic Society, Nigerian Journal of Economic and Social Studies (NJESS), in existence for over sixty years since 1959, was an exception to the trend. The quality of contributions to the journal (both from Nigeria and abroad) attest to reputation of the journal in Nigerian academia. Other good journals include journals published by Central Bank research department, CBN Economic and Financial Review and CBN journal of statistics. The hope of aspiring economist is to publish in world renown journal, to get international recognition in his field. Due to lack of funds, faculty and departmental conferences had become thing of the past. Departments of economics found it difficult to get financial and human resources to organize international conferences, as was the case in the 1970 s and 80s, when they organized conferences that attracted world renowned scholars from around the world. The proceedings of such conferences later got published in form of books and journal papers, providing students and lecturers with teaching and research materials base on their local settings.

In the developing world of Africa, Asia, and Latin America it was a tradition to castigate and condemn economic policy prescriptions coming from the neoliberal 'West' or rather the countries of Western Europe and North America. The reason for this is not farfetched, emerging from the clutch of imperial powers who colonized them for decades, third world countries professionals and academics have become wary of anything 'West'. This skceptism reached its peak with creation of World Bank and IMF who recommended beggar-thy-neighbour policies as economic prescriptions. One such program Nigerian academics always liked to refer to is Structural Adjustment Program (SAP) of the 1980s, that imposed harsh economic policies on Nigerians. Since SAP introduction, according to these academics, Nigeria has never been the same. For example, cost of goods and services have skyrocketed, Naira value relative to foreign currencies has depreciated, privatized government agencies have failed to take off, poverty has multiplied, major infrastructures have collapsed, and crimes have become the order of the day. 
In the decades after independence, Universities Economic departments were not much different from the departments of political science and Sociology who were known for their Marxist academics. Though, there were those who did not subscribe to Marxism, but antagonism towards Western neoliberal economic policies made them indifferent to issue of encroachment of Marxism into Nigerian schools. Their focus was on rapid development by other means than the harsh IMF-World Bank economic prescriptions. Names of radical economists such as Karl Polanyi, Raul Prebisch, Samir Amin, Dani Rodrik, and Torsten Persson, featured frequently in their writings. Central planning, import substitutions and inward looking economic policies of the past decades were championed by these Nigerian economists. Famous economists such as late Professor Sam Aluko, Prof. Ibrahim Ayagi, and so on, despite being trained in Europe and United States did not support neo-liberalism as Nigerian government economic policy. What happened during military regime of Ibrahim Babangida is a point of reference, President IBB had to fight Nigerian academics opposition to his neoliberal policies. To implement his structural adjustment program (SAP), IBB resorted to using professional economists, outside of Nigerian university system, for support and input - people like Olu Falae.

With the return to democracy in 1999, Obasanjo opted for the same class of Nigerian economists for economic policy inputs. His first minister of finance was Adamu Ciroma, an old school administrator cum economist, Prof. Ibrahim Ayagi, another conservative academic economist, as national economic adviser; and the Central Bank governor in the first tenure was Joseph Sanusi, another old school conservative. In his second tenure (2003 - 2007) he brought on board new group of technocratic economists, of the World Bank-IMF School. They included Ngozi Okonjo-Iweala of World Bank as finance minister, Charles Soludo, a neo liberal economist, as national economic adviser later Central Bank Governor, Mansur Mukhtar of African Development Bank as director Debt Management Office, and Ezekwesili of World Bank as education minister. Despite this apparent change of guard there was no substantial changes in level of poverty, death of infrastructures, or absence of industries needed for creation of jobs. The mother of all problems in Nigeria, corruption was never tackled and eliminated. The same neo-liberal economic policies Nigeria socialist academics fought against in 1980s are still been implemented in sectors of the economy with little or no serious opposition from the Nigeria ivory towers. This might not be unrelated with the invasion of neoliberal economic ideas across the globe and absence of credible alternatives. Hence, the question 'does globalisation finally invaded Nigerian Universities or is it Nigerian Universities are weak?

\section{Financial journalism}

Nigerian media industry can be classified into the middle ground. It is not developed like the media industry in the developed countries, but the media freedom available in Nigeria put it above those of China, Egypt, Russia, Uganda, Congo, Bahrain, Myanmar, and Algeria. The number of TV and radio stations, newspapers and magazines, and access to foreign media has doubled in the past two decades. The coming of the internet has increased media freedom beyond 
imagination. Nigerians of all age level have now priorities the internet especially social media sites such as Facebook, Twitter and blogsites for news about Nigeria and the rest of the world. The kind of state censorship of social media that is found in autocratic nations around the world is absence in Nigeria. Nigerian social media space is full of criticism of governments from the federal to state level. The international watchdog on media freedom around the world has ranked Nigeria 122th in the world in 2017. This put Nigeria above African countries such as Angola, Cameroon, Ethiopia, Rwanda and Egypt. Though, this in itself is not a good position, Nigeria must do better than this. But, in term of adaptation of high technology in dissemination of information through radio, TV and printing press Nigeria has a lot of catching up to do. For example, the kind of broadcasting technology used by Middle Eastern TV stations is higher than the technology used by their Nigerian counterparts, despite the fact that there is more media freedom in Nigeria than in the Middle East. This can be linked to the level of wealth between the two regions of the world. Thus, despite the fact that the level of wealth in countries such as China, Russia, UAE, Bahrain, Saudi Arabia is higher than that of Nigeria, that did not put them higher than Nigeria in term of media freedom. But, the depth and richness of coverage in the Nigerian media industries is far lower than in the developed countries of western Europe and North America. This is especially true when it comes to reportage of business and economics. For an economy the size of Nigeria's that put it as the biggest economy in Africa, Nigeria need to improve on this aspect. Though, lately this state of affairs seems to be changing as new actors are entering the media scene. The example, of developed nations' media emphasis on business and financial news will become clear when one looks at how CNN and BBC put business news as prime programs on their activities.

Ism as English suffix has been widely used to refer to set of ideas or system. The word journal, for example, gave rise to journalism, capital to capitalism, social to socialism and so on and so forth. But, while capitalism and socialism denote ideological movements or systems, Journalism refers to a career, a profession that according to its dictionary meaning connote 'the work of collecting and writing news stories for newspapers, magazines, radio, television and indeed the internet. Though, most online reporters or writers prefer the name blogger, to mean they maintain an online web journal accessible to everyone with internet access, meaning that they have more freedom to write what is on their minds, and that they are not limited by stringent rules and censorship that is found in both the print and electronic media. That they are moving with the changing world, the era of globalisation that saw the rise of modern technology and herald the demise of less sophisticated technologies and systems. But, not everybody welcomes this century of citizen journalist in particular and social media in general, many old journalists who practiced trade in period when internet was no more than means of sending and receiving messages see social media as threat to the profession of journalism as they knew it. These old school journalists see the business of social media as "jungle practice"; thus, rising alarm over what they saw as the growth of social media who posed a threat to practice of journalism. They observed that some of the practitioners of internet journalism knew nothing about journalism, therefore, called on authorities to censor them. But, the real threat to practice 
of journalism were people with a mindset such as this, because changes such as brought about by technology are inevitable, is either you go with it or you perished as many industries have been emasculated. One cannot just wake up and censor freedom of speech in an internet era, as dictatorial regimes in China, Egypt, and Russia have tried to do.

Coming to the central theme here; financial journalism still lags behind general journalism that comprises political reporting and current affairs. This can be attributed to the following factors, shallow grasp of financial literature in particular and economics in general on the part of journalist, mathematic-phobia (fear of numeracy), lack of interest on the part of Nigerian public on business and economic news due to poverty and low literacy, scarcity of standard economic and financial newspapers and magazines, poor training and coordination between major economic institutions in Nigeria such as CBN, NDIC, SEC, NSE, economic departments of Nigerian universities and the financial reporters, lack of interest on the part of academicians and professionals economics on economic and financial journalism leaving the business in the hand of amateurs, and finally, media owners lack of interest in the field. This is contrary to what obtains in developed countries where economic and financial journalism is as strong as general journalism competing with it on many important aspects. Economic and financial literacy in developed countries is higher than the level you would expect to get from Nigeria, making it easy for newspapers covering finance in these countries to succeed. The fact that professional economists have shown sustain interest in financial journalism in these countries have contributed to the successes so far achieved. One of the world best known weekly magazines, The Economist of London (in regular publication since September 1843) has economics, business and finance as it themes. Other international titles in finance and economic journalism include, financial times of London, Wall street journal, Business Week, Forbes Magazine, and Fortune. As Nigerian economy grow at a moderate rate, complexity in working of its sectors increases, making it difficult for reporters with poor economic and finance background to comprehend it well. As a result, financial news is poorly reported. In order to avoid these problems there is need for changes in recruitment of journalists by media organisation with the view to recruiting individual with economic backgrounds as finance and business reporters.

An average Nigerian newspaper carried three to five pages of business and financial news, this would not allow deep analysis and wider coverage of the happenings in the business world. News coverage is mostly limited to news of conferences, annual meetings, and press releases from corporate organisations including a table showing the transactions on the floor of the Nigerian stock exchange. But, expert analysis of business, economic and financial news is scanty only seen occasionally and in most cases lack rigor and technical grasp of major findings from world renown Economic and financial journals. There were few exceptions such as Businessday, a business and finance paper modeled on The economist of London and Financial Times. Most Nigerian papers lacked dedicated economic and finance columns with expert contributions. It was hard to find a good economist, for example, a university Professor with a column where he made regular contributions on economics and finance. On the part of Nigerian academic economists, there was this tendency to look at newspaper contributions as less academic and 
technical, preferring to channel his ingenuity and vast knowledge to professional journals whose circulation was limited to professionals in his field. But, elsewhere in the world, professional Economists' regular contributions to newspapers and magazines was the norm rather than the exception. Some of the world most renowned economists with Nobel Prize to their credit were regular columnists in newspapers and magazines. Prominent example here was late Professor Paul Samuelson (first American and the second person in the world to win Nobel Prize in economics) who maintained regular column in Businessweek. Samuelson was financial columnist par excellence who contributed to development of financial journalism through his column. He was recognized for contributions to major areas of economics from econometrics, mathematical economics, macro and micro economics, development economics, public finance, to consumer theory. Paul Krugman, a Nobel laureate, student of Samuelson and Professor of economics at Princeton University, contributed a weekly column to the New York Times and monthly column for Fortune magazine.

\section{Advertising in Nigeria}

The recent Economic slowdown in the Nigerian economy had negatively affected advertising industry. As the economy went into recession so did advertising market, which depended on the wider economy for revenue. According to annual report on Nigerian advertising industry in 2015 by Mediafacts, Nigeria recorded advertising spending of N97.9 Billion representing an increase of $5.2 \%$ over previous year total of N93.1 billion, but below the N103.8 billion achieved in 2013 . The authors of the report associated previous year increased in advertising to the general election of 2015 where political advertising dominated. Online advertising grew, albeit slowly. One grow area was mobile advertising where Nigeria led Africa with over 95 million mobile subscribers. Smart phone penetration had increased by $30 \%$, Nigeria was ranked 17 th in the global ranking of smart phone lovers in 2017. The resolving of regulatory conflicts such as between MTN and NCC helped to bolster advertising market as MTN was a major player in Nigerian advertising market. As a result, MTN had to advertise vigorously in order to bring back lost market share taken by rivals. Immediately, MTN appointed a Nigerian as Chief financial officer (the first) and hinted at trading its shares on the floor of Nigerian stock exchange. Other sources of growth for Nigerian advertising market included retail sector and financial industry who traditionally had large advertising budgets. The relationship between advertising level and economic growth has been found to be strong by various studies carried out around the world. Hence, it shall not come as a surprise that Nigerian advertising growth slowdown as Nigerian economy entered recession in 2016. But, what is most surprising is the absence of foresight by major actors in the Nigerian media and advertising sector to prepare for this kind of scenario. Instead waited until it happened then begin to blame the government of the day for not doing enough to stop Nigerian economy from entering recession.

As the recession bite hard, advertising revenue coming from different sectors of the Nigerian economy began to decline. An important part of the print media advertising revenue (what is 
called elite advertising) declined due to pressure by the Buhari government on corruption and related matters. It was this or what you might call 'fear of Buhari', that forced elites to put a break on advertising jamborees. Before this time, rich Nigerian families had habit of celebrating their wealth through advertising in the print and electronic media that cost millions of Naira. Events such as birthday parties, wedding ceremonies, conferment of awards, appointments into offices and so on are usually aired through advertising. But, with the change of government in 2015 so did rich Nigerians habit of wasteful advertising. According to the Mediafact 2015, Television advertising dominated in Nigeria by $40 \%$ of total media spending of the period, followed by print media with N23.7 billion (a decline of 4\% compared to previous year figure). It was the TV and Radio advertising that had witnessed increases during the period, a pointer to their dominance of media industry in Nigeria. Hence, the increased in number of TV and Radio stations. Liberalization of Nigerian foreign exchange market, deregulation of pump price of petroleum, increased in infrastructural expenditures, war on corruption, and increased in security across Nigeria's troubled regions affected the industry positively. These and other changes in the way Nigerian economy was managed sent signals to foreign investors on readiness of government to undertake needed reforms. Government focus on domestic productions provided media managers with sources of growth, as producers in the domestic economy competed to promote goods and services in domestic market. But, government slow phase and reluctance to introduced needed changes to areas of the economy affected the media industry sources of revenue.

Normally, during general elections in Nigeria the amount of advertising coming from public sector and by extension the political sphere increased considerably. Private sector has contributed in financing political parties advertising, especially of the government in power. These kinds of advertisings had less connection with movements in the economy of Nigeria. Billions of Naira worth of advertisings were carried by Nigeria major daily newspapers every time election approached. Thus, the determinant of who get what was not base on only newspapers circulation but how sympathetic the paper was to the ruling party. But, the period towards 2019 general election seemed to differ from previous election seasons. The number of political adverts is lower than the previous two periods in 2011 and 2015. This may not be unconnected to the coming of new government with mantra of fighting any form of corruption. In the past, there were strong allegations that the money used for political campaigns were stolen from government treasury. Second, the fortune of the economy compared to the previous two periods is different. Nigerian economy that depended on oil export was badly affected by the fall in the price of crude oil. But, whether it was election year or not, the federal government and its parastatals remained the biggest advertiser in Nigeria churning out billions of Naira for advertising purposes; ranging from tender notice, advertorial, rejoinder, to public notice. The Nigerian politics of advertisement, requested a paper to be answerable to federal or states governments in order to get advertising from them. Failure to do this would lead to turn off of advertising from these institutions of government. That explained why nearly all major papers in Nigeria were mouth pieces of the federal government with exception of few papers. In the recent 
past, Nigerian newspapers got billions of Naira carrying advertisements that supported federal government subsidy removal policy. But, newspapers perceived as hostile to ruling party were denied the advertising. Advertising, such as from Federal Government, were not distributed to papers on competitive (market based) parameters. This trend discouraged creativity in the industry and encouraged sycophancy.

Other main sources of adverts in Nigeria outside government and corporate sectors were congratulatory messages and obituaries. These were very common with newspapers based in Lagos; in fact, advertising scholars have put forward the view that the Lagos media purposely created elite advertising as survival strategy during the military rule from 1980s to 1990s. Nigerian elites were desirable of placing advertising in major papers for the purpose of congratulating each other, seen as symbol of power and influence among the wealthy elite. Obituary of decease rich people or their relatives was another important part of advertisement revenue generation. Billions of Naira have been spent annually on this type of advertisement. This segment of the advertising market had some relationship with performance of the economy and the amount of money the elite made mostly from ill-gotten government money. For example, major politicians and public sector workers put hundred millions of Naira in advertising to congratulate political office holders, in order to get favors. During annual presentation of National honor awards by federal government in Abuja, billions Naira worth of advert were placed by individuals and corporations, congratulating the awardees. All major dailies, television and radio stations laughed to the banks on those days. Elite advertising as it was called by advertising professionals was not the type of advertising that encourages creativity in the industry, most of the adverts placed through elite advertising were based on recycle formats and designs. And to make matters worse, most of those that placed the adverts knew little about advertisement to be able to push for creative works like in the corporate sector. It was believed (as mentioned before) that the recession Nigerian economy entered in the 1980s was responsible for newspapers going into elite advertisement that today provided the industry with billions of Naira in adverts. Obituaries and congratulatory messages had remained an important source of revenue for the newspaper industry that was only rival by public and corporate advert.

The corporate advertising companies in Nigeria were concentrated in Lagos, the hub of economic activities in Nigeria. Lagos alone accounted for some 55-60\% of all types of advertising making it the dominant location for sourcing and processing of adverts. That explained why all major advertising agencies in Nigeria were located in Lagos, as well as major newspapers companies and TV stations. According to some estimates, the total advert revenue in Nigeria increased more than four folds from 2001 to 2010, to about 98 billion Naira. Major contributors to the surge in advertising were Telecommunication sector and banking industry. They were later joined by food and beverages industry who also advertised vigorously. As Nigerian economy grew and the number of middle class increased, advertising revenue increased making the industry attractive for foreign investors who were looking for channels of investments. For example, the growth of middle class in China and South East Asia was responsible for influx of Western advertising firms into those markets. Global advertising firms such as WPP Group and Aegis 
Group of London had looked at the emerging markets for suitable environment to expand business. Being the biggest advertising firm in the world in term of revenue, WPP had operations in about 107 countries and employed over 150,000 people. Global advertising firms with operations in Nigeria included Saatchi and Saatchi, DDB, Lowe Hintas, STB McCann and Rosabel Leo Burnett. Biggest corporate advertisers in Nigeria included MTN, Glo, FirstBank, GTBank, Zenith, UBA, Etisalat, and Dangote. As all kind of producers and service providers scrambled to get share of the growing Middle Class income in Nigeria, the size of the industry must increase; the industry was billion-dollar sector that employed thousands of people. Corporate advert was most creative and competitive segment of the Nigerian advertising market where clients requested for the best from advert firms to win an advert contract.

But, for Nigerian advertising industry to realize it potentials a number of structural changes must take place in the Nigerian economy. First, the dwindling fortune of Nigerian power supply industry must change in order for the economy and the advert sector to grow without hindrances. Rapid growth of other sectors of Nigerian economy such as retail, agriculture, transportation, luxury goods, tourism and hospitality would make it possible for the client base of the industry to grow. Above all is development of the service sector, because different studies have linked development in the service sector with the growth and development of advertising industry around the world. Movement away from unethical and unprofessional practices in the industry toward globally accepted practices will help growth of the sector. Likewise, training of man power and intermingling with colleagues from advanced countries. The industry needed talents, foresight and fresh thinking, away from recycling of staled and outdated ideas. The industry will do well by borrowing from the very strong corporate culture in banking and the telecommunication sectors that represented bulk of advertising industry clients. APCON, the regulatory body of the industry, need some fresh thinking and overhauling; in areas of encouragement of dynamism, freshness, and reinvention. Advertising industry need to adjust to challenges of the digital age. Already internet has shown traditional media like print media and television, that internet alone is the future of advertisement. Advertising as part of marketing communication has played important role in development of brands in Nigeria. The future of the industry in Nigeria is bright looking at the potentiality of the Nigerian economy.

Like in other democracies around the world, the advertising industry in Nigeria has planned how to capture the billions of Naira spent by politicians in election periods. In the recent past, Nigeria's two major political parties were good for the advertising industry, due to the piece competition in placing of political adverts by members of these two parties. During elections, Billions of Naira were spent on advertising comprising the entire advertising sectors such as electronic, print media, and bill board. Because of changing dynamics of Nigerian politics and growth in Nigerian economy, the amounts of revenue generated from general elections had increased election period after election period. Unless a law is passed to reduce the amount an individual or corporations donate to election campaign, this trend would continue. The Nigerian political landscape had borrowed everything from the US system, including campaign spending. Nigeria political elites have corrupt money at their disposal that was finding its way to election 
funding. In recent years, Nigerian advertising industry had found herself in a debate about limit of foreign ownership of domestic advertising firms. The major stakeholders in the industry wanted foreign participation limited to $25 \%$, the status quo. But, a minority of stakeholders mostly foreign investors wanted limit to be removed. But, watchers of the industry such as scholars and professional consultants suggested a middle course between the two camps, recommending foreign participation of $39 \%$. This made sense because it would leave the advertising industry in the hands of indigenous companies, while on the other hand increasing foreign participation making them important stakeholders in the development of the industry. The good thing with globalisation is that it brought with it global standard parameters that shape local industry for the better. Nigerian advertising industry needs the creativity, capital, and managerial know how of global advertising companies. While desirous of benefitting from the global best practices, the industry must be wary of predatory practices of global companies that harm national interest. Dumping of advertising on local markets by foreign agency was real, taking into consideration the practices in the recent past. But, regulation by supervisory bodies such as APCON, BON and ministry of information would go a long way in sanitizing the market.

Globally, marketing communication industry had adopted cutting edge technologies making it operations efficient and satisfying changing tastes of consumers. Global adaptation of internet for advertising had awoken the Nigerian advertising industry from slumber. Corporate agencies had started allocating money for advertising on internet sites such as Yahoo, Facebook, Google, LinkedIn, Twitter and YouTube. This strategy had help them reached large target audience possible at the most efficient cost possible. Since the advent of democracy, Nigerian advertising industry has witnessed rapid growth. Today, the industry is a billion Dollar market. These developments had translated into positive things for Nigerian economy, among which are increase in job opportunities for teeming unemployed graduates coming out of tertiary institutions, additional tax for Nigerian government as revenue base of the industry blossomed, more investment opportunities for both local and international investors, growth of the local industry enabling it compete in the global market, and development of local talents. The private sector of the Nigerian economy had played important role in the development of Nigeria. Private sector players have contributed billions of Naira to campaign trains of politicians. As Nigeria economy grew so did corporate image making through branding. Major brands such as Dangote, First Bank, MTN, Glo, BUA, GTBank, UBA have spent billions of Naira in order to increase brand strength, what branding experts called Brand equity. Less well known brands such as Shoprite, TATA Nigeria, Dantata \& Sawoe, were also busy spending money in order to increase their presences in the market. Nigerian advertising industry is a developing market, it would take years before reaching the level of advanced markets such US, France, UK and Japan. Annual advertising revenue for Nigeria economy was less than South Africa's, whose advertising industry was at higher level of development than Nigeria's. In term of creative contents in advertising messages, Nigeria lagged behind the emerging markets of Middle East and North Africa (MENA) region. The Nigerian advertising market was oligopolistic, dominated by few local actors. These local agencies fought any potential new entrance into the business whether they were local or international. 
But, for future development of the industry, there must be fair play, competition and effective regulations.

The internet, especially, social media (Blogs, Twitter, Facebook, Google, Linkedln, etc.) has forever changed news (print media) as we knew it. But, that is not the end of it, new destructive technologies are being developed every year. There was a gradual decline in newspaper business in developed countries. But, in emerging countries such as India, China, Brazil, and South Africa newspapers had experienced growth, some level of higher market penetration. The two mighty forces of 'Internet technology and Economic growth' have changed the historical permutations in the development of print media. While developed economies were passing through tumultuous period, emerging economies were prospering; and in another area, while use of internet was high in developed countries, it was low in emerging countries. Internet revolution had big effect on advertisement revenue, the most important source of income for newspapers. It has reduced the amount of advert revenue going to print media, directing big share to internet advertisement. By reducing advertising revenue, changing news into commodity and blurring old boundaries between different media organizations, the internet has brought revolution to newspapers' traditional business model. Though Nigerian media falls under the emerging group classification, who were experiencing high growth, the industry was affected by the internet revolution. The number of online media and social networking site such as Premium Times, The cable, Gamji, Sahara reporters, Nigerian village square and news blogs have doubled. Recently, Nigeria was ranked among the top nations with dominance in internet usage by means of mobile devises. This further pointed to the threat of internet to the Nigerian newspaper industry. Facebook, a lone, has changed the way young Nigerians read news. People now no longer go to newspapers websites, they get all the news they need on their Facebook, Twitter, Linkedln or Google+ pages. As national power supply improves and telecommunication companies made promised infrastructural investment boosting internet access, percentage of Nigerians with access to internet will jump making Nigeria to follow examples of China and India. Domestic internet giants were gradually spring up, making migration of advert to internet prominent. TV, radio and outdoor advertising were the main competitors to print media in advert generation. Looking at demography, internet penetration and socio-economic setup of Nigeria, the three will continue to compete with newspaper in the foreseeable future. But, all the four combine have a monster competitor in the internet. The fact that about two third of Nigerian newspapers income was coming from advertising would continue to make soliciting for adverts highly competitive.

A stumbling block to development of unbiased media in Nigeria has been advertisers influence on news and editorials, as I mentioned elsewhere. Because of advert sourcing needs, papers to some extent allowed politicians and corporate bodies to influence news reportage. This must stop if Nigerian media industry is to maintain good name. Across Africa, media industry was held hostage by dictatorial governments. In Egypt, Sudan, Congo, Chad, Algeria, Zimbabwe, and Cameroun there was absence of media freedom. Despite the grim future for print media worldwide, as a result of internet, Nigerian print media might witness growth in revenue 
defending on the health of Nigerian economy and the effort being put in place by major actors in the industry to developed the sector. Nigerian government should do everything possible to encourage competition, a situation whereby all the media's major actors are located in one region of the country is not healthy for the industry and Nigeria as whole. There is need for balance and geographical spread. As Nigerian economy prospers number of advertisements placed by corporate bodies and governments would increase, putting the print media in better position to generate more revenue and create jobs. Another area of growth in revenues was circulation, the number of middle income earners would increase thereby boosting number of people with income to buy a daily paper. This scenario had occurred in India and China, where millions of people were lifted out of poverty, allowing them to buy a daily newspaper. Though, Nigerian newspapers relied on advertising for incomes, newspaper circulation shall provide more revenue for those media companies that made critical investments necessary to tap circulation revenue. For example, more than $70 \%$ of newspapers revenues in Japan came from daily circulation not advert. But, this should not come as a surprise, one of Japan top daily papers had daily circulation of about 10 million copies.

Due to 2017 recession and impacts of information technology, Nigerian papers have started to charge fee for some of their online contents, that used to be free. This is in line with the global trend, where major newspapers have started to charge for online content, instead of making them freely available for users. Since young readers were moving online, competition for online advertising would intensify concurrently with the print paper. Thus, the existing print papers in Nigeria shall focus less on competing with one another at the newspapers selling stands around Nigeria and focus more on competing with highly creative and changing internet contents. This scenario is similar to the beverage drinks makers such as Coco Cola and Pepsi realization that they have major competitor in the water (which seemed to be free like the internet contents) their customers used. When Nigerian advertising industry matured, one shall not rule out merger and acquisition in print media. As a result, local and foreign investors would pour money in order to get cut of the expected profits. With the coming of social media, journalism is no longer an exclusive preserve of journalist. Ordinary Nigerians are playing active role in dissemination of news. Though, proliferation of fake news has made people wary of online news. Social media is certainly not a fad, and its impact is only just beginning to be felt after most Nigerian media houses had taken it for granted. The Nigerian media organizations that will survive social media are those who accept this new reality. Media organisation must know their market niches and serve them very well. Nobody knows what the future will bring, but as a popular adage has it, the only certain thing about the future is its uncertainty.

\section{Technology Startups}

With human efforts and brainpower anything is possible. Through the use of his brain, man was able to land on the moon, made breakthroughs in healthcare and agriculture, split the atom, developed new sources of energy, and of course created the internet. Nations around the world 
have used technology to change the fortune of their economies, from Israel use of technology to revolutionize agriculture, Japanese use of high technology to introduce revolutionary electronic products, US development of the internet, Germany leadership in automobiles production to South Korea's path breaking mobile electronics industry. The secret behind all these is investment in knowledge. The power of knowledge to turn nations devastated by wars such as East Germany and Japan after the second world war, South Korea after the Korean wars and Taiwan after the Chinese civil war has never cease to amaze me. Knowledge a lone endowed human being with vision with which to foresee how to change his environment for the better. The efforts being made in the field of artificial intelligence have the potential of expanding the capacity of man to improve his environment through future researches that are not possible today with our current capacity. These efforts and the race to acquire state of the art technology is being carried out in the advanced economies of the world. Africa with its poor knowledge infrastructure is only a spectator. Africans would be slaves to the more advanced nations of the world, unless they change the present state of affairs. Nigeria has been left behind in the area of modern technology, just like the other African countries. Nigeria and other African nations have become importers of whatever is produced by these advanced economies, at the same time they are not making any serious efforts to make their own breakthroughs. The problem of brain drain has done much to undermine past efforts aim at development of specific sector of the Nigerian economy to compete with the rest of the world. But, the advancement being made in the area of information technology has awaken many countries around the world, including from the developing world. The simplicity with which young geniuses, using personal computers, are coming up with revolutionary applications made this more interesting.

Now a day, when the term Startups is mentioned the first thing that come to mind is Silicon Valley in the United States which as technology hub came to being sometime in early 1970 s. The name Silicon itself originated from silicon transistor which served as the building block of transistors use in making computers. Silicon Valley started with two to three companies and decades later it becomes what it is today, the world largest technology hub. In this technology setup is found a unique combination of technological knowhow and business acumen, with seed capital provided by venture capital firms. Today's celebrated internet celebrities such Mark Zuckerberg, Sergey Brim, Steve Jobs, Bill Gates, Jeff Bezos and numerous other less well known started as computer/internet enthusiast who possessed good ideas without the needed capital and entrepreneurship skills to transform them into money. It was the venture capital firms that came to their aids by providing capital and entrepreneurship skills needed to create today's giants such as Facebook, Apple, Google, Yahoo, Amazon, LinkedIn, Twitter, Cisco Systems, Hewlett Packard, Adobe, Intel to mention just a few. Today, Silicon Valley has the highest concentration of millionaires and billionaires per head in the United States itself. This phenomenon of establishing Start Ups is fast spreading around the world. In a recent global innovation ranking released by World Economic Forum, smaller countries like Switzerland, Israel, and Finland were put ahead of US which came $4^{\text {th }}$ in how fast countries are innovating. This show how countries around the world are competing to stay ahead in term of technological innovation. 
Nigeria needs its own Silicon Valley with its own combination of young technology geniuses and venture capitalists. Internet giants such as Facebook, Google and Transport companies like Uber have realized the potentials of Nigeria in this field and are working hard to get there first. The visit to Nigeria by Mr. Zuckerberg in 2016 was a clear signal of the potentials Nigeria has in this direction, taking into consideration the abundant talents and huge population of Nigeria. Up till now Nigerian government did not have a clear blueprint on how to make Nigeria the technology hub of Africa. At the level of state governments, what are they doing to develop this sector? Virtually nothing, with the exception of Lagos where the concentration of various kind of businesses and talents led to the start of one to two technology startups, there was not much to show. It will take the combination of academia, businessmen and government to produce something akin to Silicon Valley in Nigeria. Ideal places for such combinations in Nigeria would include Lagos, Ibadan, Abuja, Kano, Kaduna, Bauchi, Enugu and Port Harcourt. Many countries around the world have established their own Silicon Valley like hubs, India, China, Israel, Pakistan, Russia, Brazil to mention just a few. Young Nigerian entrepreneurs such as Oscar Ekponimo base in Abuja used technology to bring wasted food to the hungry through his new software application Chow berry. People like Oscar Ekponimo are not few in number in Nigeria, there are hundred others waiting to be discovered. Nigeria shall learn from the example of Israel where government provides part of the money invested by venture capital firms in new startups. In Pakistan young technology enthusiast were provided with free working tools, office location, and internet access to start developing their talents. 


\section{ISLAMIC ECONOMICS, BANKING AND FINANCE}

Nature of Islamic Banking

Islamic banking is just one branch of modern finance. The more common banking model that everyone knows about is conventional banking. But, what makes Islamic banking to differ from traditional banking is having its core doctrines to be originated from Islamic jurisprudence. The same mathematics, statistics and other analytical tools employed in conventional field of finance are the same in Islamic finance. In fact, most academics contributing to Islamic finance started as conventional economists. In term of practice of the system, the same current account obtains in conventional banking is found in Islamic banking, the differences are few. Likewise, concepts of customer care, human resources, physical structures, information technology as back bone of the industry. The main differing factor as even the name 'non interest' donates is Islamic banking does not accept transactions involving interest, gambling, exploitation and greed. The foundation of the system is justice and entrepreneurship. Instead of interest rate as rewarding mechanism, Islamic banking replaces it with profit and loss sharing where profit or loss are shared between parties to a transaction. Unlike in conventional banking, Islamic banks are restricted in the nature of their investments, they are not allowed to put their money or that of their customers in transactions that has elements of gambling, speculation or is highly risky like in conventional derivatives. They are also not to trade in alcohol, pork, pornography and prostitution. To ensure Islamic banks comply with all these an independent board is constituted, called 'Shari'ah board' saddled with responsibility of ensuring observance of Shari'ah guidelines in financial transactions.

The geographical distribution and nature of growth of the industry worldwide have changed a lot from its narrower base and slow growth of the 1970s. Even though the first Islamic bank to start operation originated from Egypt during the early 60s, practice of Islamic banking has become a global phenomenon found in all corners of the world. Today, there is no globalize financial institution worth it name that is not engaged in Islamic banking or other aspects of Islamic finance, or considering going in. Global brands like HSBC, City group, Barclay bank, BNP Paribas, Bank of America, Deutsche Bank, Chase, Union Bank of Switzerland to mention just a few have gone into one type of Islamic finance or the other. International financial institutions like the World Bank and IMF have established units in charge of Islamic banking and finance. Between them, they have produced hundreds of working papers on Islamic finance and Economics over 
the last three decades. Some of the most outstanding contributors to the field of Islamic economics and finance are staffs/ex-staffs of these institutions. Two ex-staffs of IMF Mohsin Khan and Abbas Mirakhor were awarded the most prestigious prize in the field given by Islamic Development Bank in 2001, for their contribution to the field while working with the fund. It did not surprise me when former finance minister Dr. Ngozi Okonjo-Iweala gave her approval of the practice of Islamic banking, because of her background as ex staff of the World Bank. From few million Dollars in asset when it started, Islamic finance has grown to reach trillion Dollars worldwide. Growing at the rate of fifteen to twenty-five percent annually, Islamic finance has been adjourned the fastest growing segment of international finance.

Those familiar with investment terminologies know of portfolio diversification. It says that to avoid situation where investor put all his eggs (investments) in one basket, thereby expose to high degree of risk, he shall divide the eggs and put them in difference baskets. The result is that the degree of risk is reduced. Global investment community has come to realize that Islamic finance has provided healthy environment by allowing investors to diversify their investments away from the kind of toxic assets that caused past global financial crisis. The above factor explains why significant numbers of customers patronizing Islamic finance products are nonMuslim. More than half of Nigerian public do not transact business with existing banks, for reasons that include poverty, lack of awareness and religious considerations. Islamic banking will help bring substantial number of these unbanked into the formal banking stream. Thus, helping in increasing financial deepening in the economy. This will in turn accelerate economic growth and development of Nigeria. Islamic micro finance institutions have been hailed worldwide including by IMF studies as comparatively stronger than their conventional counterparts. The introduction of these Islamic micro finance institutions shall help in assisting government to achieve its objective of financing small and medium scale enterprises. Some branches of Islamic finance, for example Sukuk, has been hailed as innovative financial product that is competing with similar products conventional economic and finance offers. Sukuk is a hot cake embraced by governments around the world to manage their fiscal problems. Nigerian authorities, as I mentioned before, have already tested that and found Sukuk to be an important channel to source the money it needs to finance its budget.

Islamic economics offers solution to economic ills such as poverty and inequality, caused by no other thing than greed and lack of empathy found in capitalism. One needs no better example than the past global financial crisis of 2008 that caused havocs around the world. Capitalist finance with its unethical philosophy of 'beggar thy neighbor' that has greed as it 'motto' and selfishness the driving force need ethical injections into its main body frame before it throws the world in far more destruction than the previous crises. Eminent personalities around the world have argued along this line among them past Nobel laureates, politicians and theologians from different religious back ground. In Nigeria, as government moves toward achieving economic growth and development, I am quite sure the introduction of the novel scheme of non interest finance would contribute towards achieving its objectives. The argument that Islamic banking is an agenda to Islamize Nigeria is not true, because introducing the same system did not Islamize 
other countries who introduced the scheme before Nigeria. As an ethical financial arrangement, Islamic finance would help Nigeria reduce problems of economic and financial scams. CBN and relevant agencies must continue to educate the Nigeria public about the scheme and its virtues.

Non-Interest banking should be viewed as it is, as measure to check the exploitative excesses of conventional banking. Derivatives, greed, and especially exploitative interest rate are cause of past global financial crises. Islamic banking replaced interest with profit and loss sharing (PLS). This is done to remove from the system source of exploitation and instability that favor lender over borrower. Credit default swaps (CDS), that Warren Buffet called weapons of mass destruction, is one tumor bedeviling global financial system. Then greed, that inspired people to put money into highly risky ventures. Whatever name you give it: risk shifting, speculation, short, or long selling, excesses are at the heart of financial crisis. Nigerian banking system has failed to maintain balance between conflicting interests of individuals and society. Bank managers used depositors' money to enrich themselves and family. It is easy to deviate from rules on bank credit where loan condition centred on collateral instead of ability and skills of borrower. With collateral, bank's lending officials just lend money. Banks Managing Directors sacked by former CBN governor Sanusi Lamido were accused of lending money to own companies and cronies. These loans were given for speculative investment in shares and luxury properties. In Islamic finance, Islamic bank decide whether or not to support project on basis of cost benefit analysis not collateral. High moral standard and conservative tradition of Islamic banking do not tolerate speculative lending. In Islamic banking, credit creation is not allowed unless it is trade credit or interest free loan. What are encouraged are business ventures run according to profit and loss sharing principle. Profit and loss scheme encouraged entrepreneurship and cooperation, instead of speculation and cut throat competition. Islamic banking unlike conventional banking abhors injustice and exploitation and seeks to forge human relationships on the basis of justice and cooperation. Interest under Islamic ethical system is unjustifiable. The non-performing loans uncovered in previous Nigerian financial crisis were caused by borrowers in ability to service debt. High rate of interest made it difficult to create business enterprises instead skewing money to speculative activities. High interest had caused the third world debt crisis of 1980s and Asian financial crisis of 1997/98.

Total value of Islamic financial assets around the world is put at over \$2 Trillion. Islamic finance has enjoyed double digit growth in recent years. Islamic banks have operations in major global financial centers, from New York, London, Frankfurt, Dubai, to Hong Kong. There are Islamic stock indexes in major stock exchanges like New York, Bahrain, London, Dubai, Jakarta and Malaysia. Islamic bond 'Sukuk' has become darling of corporate and government financers, used by companies and government in US, UK, Switzerland, Pakistan, and Malaysia. Nigeria had lost a lot from its initial reluctance to adopt Islamic finance. Islamic monetary system has economic stabilization and resource distribution advantages. It has advantage as source of foreign direct investment for Nigeria. Malaysia used Islamic finance industry to make her economy strategic in global financial arrangement. Malaysia was able to attract billions of dollars of Islamic investment from Middle East. International Monetary Fund (IMF), in more than one 
study, have discovered that Islamic and conventional banks can co-exist in the same economy without substantial "crowding out" effects. On religion of the sympathizers of the system, some of the contributors to Islamic finance were non-Muslims. Academics like Professors Rodney Wilson, J. Presley, and Volker Nienhaus are Europeans. Gains to Nigeria from Islamic finance include financial deepening (increase coverage of citizens by financial system), increase economic stability (because of reduction in debt to equity ratio) and increase in risky equity capital (because of replacement of Interest with profit and loss Sharing). Islamic micro finance model is complementary to conventional micro finance. Micro finance banks were originally conceived to help the poor meet their financial needs neglected by bigger commercial banks. That has been the aim of Islamic banking, empowerment of poor who doesn't have collateral but have viable projects. In Islamic finance, Qard Hasanah (benevolent loan) help poor that need loan without demanding to make profit from him. Islamic microfinance has advantage over conventional counterparts when it comes to interest. Conventional micro banks charged poor higher rate of interest on the ground that lending to poor is risky. But, prohibition of interest replaced by profit and loss sharing and mark-up modes of financing shall take care of that issue under the Islamic model. Islamic micro finance bank uses mode of financing ranging from Mudarabah (partnership between the bank and the borrower) to Murabah (trade finance in form of working capital loan) to ljarah (leasing). An IMF study show that small Islamic banks tend to be financially stronger than corresponding small conventional banks.

As sub Saharan African largest economy and most populous country, Nigeria's introduction of Islamic finance shall be welcomed by global investment and Islamic banking and finance communities. With Seventh largest population in the world, Nigerian financial market is large enough to attract any type of financial market player. The history of the introduction of ethical finance into Nigeria can be traced back to pre-independence period when an institution that did not engaged in interest related dealings was established to cater for needs of Muslim pilgrimage, for an ethical vehicle through which they can channel their saving toward annual pilgrimage to Mecca. The agency popularly known as WAPA, though not a bank, in some ways perform bank job of deposit taking and functions of bureau de change. But, effort to establish a fully pledge Islamic bank can be traced to 1980s after liberalization of banking sector and establishment of what are today called new generation banks. The promulgation of Bank and other financial institution degree (BOFIA) of 1991 acted as watershed as it provided legal and constitutional backing for establishment of Islamic banks. Thereafter, establishment of community banks across Nigeria paved way for Muslims to apply for establishment of zero-interest community banks. Habib Bank Nigeria limited (an affiliate of Habib bank Pakistan) was the first conventional bank to open a window for Islamic finance in 1996. Because of absence of support from monetary authorities no other bank followed the example of Habib bank until years later. After return of democracy in 1999, efforts to establish fully pledge Islamic banks were re-initiated. This time around, because of positive posture of authorities towards the initiative; shares of the proposed Islamic bank (Ja'iz Bank) was opened to general public. The share offering was oversubscribed, a signal of eagerness of Nigerians for introduction of this type of banking. But, as I mentioned 
elsewhere, a 2003 decision of Charles Soludo (the then CBN governor) to increase banks' capital base from N2.5 Billion to N25 Billion delayed Ja'iz Bank take-off for another ten years.

Ja'iz Bank Plc had witnessed growth in the past two years that surpassed what was seen in Bangladesh and some Middle East countries, including in case of some of Nigerian conventional banks. Since inception in January 2012, Ja'iz Bank has grown investment to over 22 billion Naira in its first two years of operation, despite the numerous obstacles on its path as being the only non-interest bank in Nigeria. These successes came at a time when there were changes in the Central Bank of Nigeria policies. Looking at the performances of Islamic Banks elsewhere around the world, one can be confident about the future potentials of Ja'iz Bank if handle well by its management. Africa richest man (Aliko Dangote) is among the biggest shareholders of the bank. The bank has become a national bank from its former position of being a regional bank that operated in the Muslims dominated Northern Nigeria. Being the only Islamic Bank operating in Nigeria put a lot of obstacles in the way of Ja'iz Bank. Only people that are very familiar with the operations of Islamic Banks around the world will appreciate what the bank has achieved. But despite these, the management of the bank have managed to grow its investment portfolio at the rate of $380 \%$ in the first two and half years of its operation. Its customer's deposit grew even higher at the rate of over $460 \%$ in the same period. Still higher for overall period at the rate of 750\% during the time. According to the bank management, the use of state of the art IT equipment have contributed a lot to this success. The vision of the Bank was to be the largest non-interest financial service provider in the Sub Saharan Africa. In recent years, Islamic insurance companies from Middle East and South East Asia have been scrambling for the Nigerian market. The requirement for establishment of an insurance firm unlike Islamic bank are more relax.

Islamic banking: a brief history

The road to Islamic banking in Nigeria has been rough right from its inception. This was mainly due to multi-religious and ethnic composition of Nigeria. Unlike in other parts of the world where the ethical banking program got support from different angles: government, academia, professional and general public. In Nigeria the situation had proven to be a difficult case study in adaptation of a new banking model. Where sections of Nigeria saw the initiative as a way of given preference to one religion and people over others. But, the Nigerian Muslims viewed Islamic finance as legitimate right given their own non compatibility with the conventional system and the fact that the level of financial deepening is higher in the south than the north. The same thing was true in the academia, while southern intellectuals approached the system with skepticism, those in the North saw it as positive move capable of bridging economic gap between the sections of the country. Nigerian government and the central bank in particular did not helped matters. Central bank plethora of policies were stumbling block to the takeoff of Islamic banking. Surprisingly, the banking and finance professionals in Nigeria constituted a segment of Nigerians ignorant of the system. Since the start of efforts to introduce Islamic banking in the 80 's, the 
program had remained as it was, in papers as policy draft; until two and half decades later. At different times, governments of presidents Babangida, Abacha and Obasanjo had made promises on their desires to introduce the banking model, but at the end it turned out as policy pronouncement meant to prevent any possible tension from supporters of the scheme. Since the promulgation of Bank and other financial institutions acts (BOFIA) in the early 90's, and an attempt by the former HABIB Bank Nigeria to open a window to cater for the need of the Muslim public, there was no other major land mark until decades later. Charles Soludo's brief attempt at Islamic banking introduction had ended up producing a policy guide. But, the nitty-gritty of laying solid foundation for Islamic Banking like recruitment and training of manpower, and the money and capital market infrastructures were not provided. It took another decade later on before the starting of operation of a full pledge Islamic bank.

In other countries, laws were reviewed to allow establishment of Islamic banks by foreign investors. But, it was only in recent time that Nigerian monetary authorities started to look in that direction. Wealthy Nigerians were reluctant to put money in the sector. As mentioned, lack of policy and infrastructures would not allowed it. Banking professionals failed to understand the enormous foreign investment potentials provided by Islamic banking which the Middle East, South East Asia and Western world have been using to their own advantage. Nigeria could have used Malaysian model where conventional banks were encouraged to start independent Islamic banks, a kind of subsidiary. The resources at the disposal of Islamic Development Bank (IDB) based in Jeddah, Saudi Arabia, providing assistance to countries establishing Islamic banking system, was neglected by Nigerian monetary authorities. The same thing happened with opportunities for collaboration with countries leading in this area. There were efforts, particularly coming from Usman Dan Fodio University Sokoto and Bayero University Kano, on research and training of manpower in the area of Islamic Banking and finance during the 80's and 90's. Usman Dan Fodio University was the first to introduce courses in Islamic Economic and finance in Nigeria. The enthusiasm of the university for the development of the scheme was killed by apparent lack of concerned shown by government. Through collaboration with institutions around the world, Usman Dan Fodio University had hosted an international conference that gathered pioneers in Islamic economics and finance from around the world. The like of late Sule Ahmed Gusau and Professor Mohammed Lawan Bashar of the university were some of the brains behind the early feasibility studies on the working of the system in Nigeria. Bayero University has also established its own Institute for Islamic Banking and Finance for training of manpower. Central bank of Nigeria under Sanusi Lamido had by then made pledges to actualized the system in Nigeria. The later categorization of Nigerian banking system into groups by CBN had gone a long way in helping to make Islamic banking a reality. In Nigeria, where more than half of its population was outside the banking system, programs that helped increase access to banking should had been welcome long before now. Islamic finance has become an important segment of global finance that could not be ignored.

Ja'iz bank has become synonyms with non interest banking in Nigeria. It all started from 2002 when movement for establishment of Ja'iz bank plc gathered momentum to 2012 when Central 
Bank of Nigeria finally gave the management of the Bank go ahead to commence operation. It has taken a decade to establish the bank making it one of the few to take that long. But as I mentioned earlier, Ja'iz is not the first institution that was proposed as Islamic Bank, before it there were many attempts, starting with WAPA (West African Pilgrimage Agency) of the colonial era. WAPA was established to cater for financial arrangements of Muslim pilgrimage, a name that is still remembered in places like Kano. The list of other ethical financial institutions includes Habib Bank and numerous community and later micro finance Banks established for the same purpose. But, what make Ja'iz unique is the scale of the project and the hope placed on the institution by millions of people among them ordinary investors who put their hard earn savings in the institution. At the end of the first public offering by Ja'iz in 2003, the Bank was able to raise the minimum capital required for establishment of commercial bank in Nigeria (minimum capitalisation was at the time 2.5 billion but the bank raised over 3 billions). There were jubilations in parts of Nigeria, by people who shared in the dream of its founders. But, the jubilation was cut short with introduction of Charles Soludo's banking sector consolidation requiring banks to jack up minimum capital from 2.5 Billion to 25 Billion Naira. Thus, banking sector consolidation had blocked the efforts to establish Islamic bank until a decade later when the policy was reversed by his successor at the Central bank of Nigeria.

Islamic finance in the world is trillions dollar industry. For decades now Islamic banking has grown at double digit rate, making it phenomenal as it moves to acquire market share. Islamic Banking has been recognized as a novel model with potential to contribute to growth and stability of the global monetary system. There are hundreds of Islamic banks operating around the world, from Indonesia to United State, South Africa to Germany. The rate at which Islamic finance is entering Western and Eastern countries is commendable. The two major hubs of Islamic banking in the world are Gulf Cooperation Countries (GCC) and South East Asia, they accounted for majority of the big Islamic Banks in the World. Other regions of the world where Islamic banking has witnessed growth includes Indian subcontinent, Africa, and Europe. In Africa South of Sahara, potential of the system is enormous. For example, in South Africa, despite that the Muslims are a minority, Islamic banking has grown over the decade. Islamic banking is growing in Kenya, Senegal, Ghana, Uganda, Somalia, and Guinea. Nigeria is relatively a new entrant in the industry. Though, agitation for the system started decades ago. The fact that Nigeria has a fast growing financial industry is a great plus for Islamic finance.

The first commercially oriented Islamic Bank in the world had started in UAE in 1975. Though, attempts at establishing Islamic Bank were made in the past (in Egypt and Malaysia) none succeeded like UAE's Dubai Islamic Bank. During the global financial crisis of 2008, Islamic banks showed resilience impressing everyone including conventional critics. Islamic banks were not affected by the crisis like conventional counterparts. In an IMF 2010 working paper title, 'the effect of the global crisis on Islamic and conventional banks: A comparative study', the study observed credit and assets grow in the Islamic banking industry during the period 2008-09 perform better than in conventional counterparts and contributing to financial and economic stability. At the root of the concept of Islamic banking is removal of interest and its replacement 
with profit and lost sharing. This contrast with conventional banking built on interest premium without which the system collapses. It explained why conventional economists, in early years of Islamic banking, argued that the system would not work simply because interest is eliminated from the equation. A strategic alliance between bankers and Ulama (Shari'ah scholars) contributed to the rapid development of Islamic finance. It enabled Islamic banking system to create a financing and deposit sourcing model that differs from traditional models developed in early Islamic economic literature. Therefore, enabling Islamic banks to compete with conventional banks in the same environment. Today, the level of financial engineering in Islamic banking industry (though, still below level obtained in conventional system) is impressive.

Lotus capital Nigeria Ltd is a pioneer in the field of Islamic fund management being the first institution in the country to lunch halal management fund back in 2008 when it made its initial public offering (IPO) to the public. Since that time, the fund has achieved a lot including the revolutionary lunching of Islamic share index in association with the management of the Nigeria stock exchange in 2012. Its Halal fund has attracted patronage from across the country, with investors cutting across faiths. Among other activities of Lotus capital was giving advice to state governments on how to manage their budgets and avoid budget deficit through the use of Sukuk, the Islamic bond that do not use interest related instruments. The first Sukuk issued in Nigeria by the state of Osun in South West Nigeria was managed by Lotus as the leading issuing house of the project. At the end of the issuing in October 2013, a total of N11.4 Billion was realized. Among the major investors in the Sukuk issued was Ja'iz Bank Plc, the first fully fledged Islamic Bank in Nigeria. For a country the size of Nigeria with population of over 190 million people, not less than half of them belonging to the Islamic religion, it is sign of underutilization of opportunity that there are only two major institutions in the country who called themselves Islamic financial institutions. Looking at the size of Nigerian economy being recently ranked the biggest economy on the continent with annual GDP of about half trillion Dollar, the country should ideally have sizable number of Islamic financial service players running their businesses. Thus, the ideal thing to do for a country like Nigeria is not to depend on only Ja'iz and Lotus as the two major players in the field. While all business people who care much about ethics and their business should patronize them, efforts shall be made to see that many others like them come on stream. This would go a long way in ensuring the survival of the system in the country and ensure that the country and its people benefit from this unique system of financial and business transactions.

Having the largest Muslim population in Africa, one would have expected Nigeria to be the leader in Islamic finance in Africa but that position goes to Sudan. Nigeria is late comer to Islamic banking and finance having gotten her first Islamic bank in 2012. Sudan is the first African country to accept the Islamic banking system and convert its entire financial system to level compatible with the Islamic system. It also issued Africa's first Sukuk bond through a Sudanese cement company. It is among the three countries in the world to attempt total conversion of their monetary and banking system to Islamic monetary system. While the first modern Islamic bank in the world is believed to have being established in Egyptian town of Mit Ghamr in 1963, though it operation was short lived as it was closed. Sudan remains the biggest market for Islamic finance 
in Africa followed by Egypt. South Africa is doing better in term of adaptation of the Islamic banking model than either of Nigeria, Algeria and Morocco. The first Islamic bank to open in South Africa was Albarka Bank in 1989. According to some estimates, Africa has only about $2 \%$ of the global Islamic banking assets and only $0.5 \%$ of outstanding Sukuk despite having over a quarter of the total global Muslim population. Muslims make up about half of the population of Africa. Another study, put the share of Islamic finance in Sub Saharan Africa, as share of the total global market, as 16.6 in 2012. There are currently Islamic banks in Algeria, Botswana, Chad, Djibouti, Kenya, Egypt, Tunisia, Gambia, Guinea, Liberia, Libya, Niger, Nigeria, South Africa, Mauritania, Mauritius, Morocco, Sudan, Senegal, and Tanzania. Kenya, despite having its Muslims population not in position of being the majority, its first Islamic bank was established back in 2005 by Barclays bank. Since that period, more Islamic banks have opened their doors in Kenya. In Nigeria, the first Islamic banking window was open by Habib bank Nigeria plc (a subsidiary of Habib bank Pakistan) in 1992, but Nigeria's first fully fledged Islamic Bank Ja'iz Bank Nigeria plc only open its door in 2012 despite raising capital for that purpose way back in 2003. Other banks operating Islamic banking window in Nigeria include Stanbic IBTC plc and few micro finance banks. Senegal first Islamic bank Banque Islamique du Senegal (BIS) its biggest Islamic bank was established in 1983.

During the eve of introduction of Islamic banking model in Uganda, the governor of Bank of Uganda Prof Emmanuel Tumusiime-Mutebile was quoted to have said: "We should not think that Islamic banking and finance is only for Muslims. It is for all of us. Therefore, you need to come out and stress the unique tenets that distinguish Islamic banking from the conventional banking and compare the similarities too," Ugandan central bank is putting things in place for the introduction of supervisory manuals and regulatory framework on Islamic banking in the East African nation. Among the major factors slowing the growth of Islamic banking in Africa are: Ignorance about the system, absence of initiative on the part of African leaders, lack of Shari'ah compliant investment vehicles, poor legal and regulatory frameworks, unnecessary oppositions (base on ignorance of the system) from non-Muslims, absence of commitment from Africa based research institutes, and lack of trained manpower. In view of these, multinational financial institutions like African Development Bank shall lead the initiative just like the IMF and World Bank are doing at the global level. Considering the position of Nigeria in Africa, based on its economic and population strength, Nigeria shall also join in leading the initiative to make Africa a world leader in Islamic finance. Nigeria shall aspire for more Islamic bank and put environment in place for tapping the enormous potentials in Sukuk bond. In 2017, Nigerian government issued her first Sukuk of one hundred billion Naira to the global investing public. The offering was immediately oversubscribed, pointing to the attraction of the instrument. The Buhari administration that issued the Sukuk had already used the money for building of roads around Nigeria. 
What next for Islamic finance?

Soludo had compiled policy documents on Islamic banking introduction in Nigeria, but his other policies like the sudden introduction of 25 billion Naira capital base for banks became a stumbling block. In addition, Soludo had refused to put the needed regulatory and legal requirements for establishment of Islamic banks. Despite these, Soludo initiated Nigeria into Islamic Financial Service Board (IFSB) in January 2009. Sanusi was credited with using BOFIA (banks and other financial institution acts) degree of 1991 to restructure non interest specialized banks in 2010 to conform with Islamic Banking requirements. With dismantling of universal banking model, the capital requirement for establishment of Islamic bank was reduced from 25 billion Naira to 5 billion Naira for a regional bank, and 10 billion Naira for a national bank. The Nigerian Deposit Insurance Corporation (NDIC) also joined CBN by releasing draft framework for non interest (Islamic) deposit insurance scheme. Central bank under Sanusi also joined the International Liquidity Management Corporation based in Malaysia in October 2010. Sanusi also introduced the office of adviser to CBN governor on Islamic banking, in addition to sending staffs of the bank for training in and outside the country on various aspects of Islamic banking. All these led to drastic changes in Islamic Banking environment. Thereafter, Ja'iz bank plc was registered as full pledge Islamic bank, making it the first Islamic bank in Nigeria. Stanbic IBTC Nigeria limited (a subsidiary of Standard Bank of South Africa) also had licenses to operate window of Islamic banking. Other conventional banks had planned to enter the market. Lotus capital plc had been registered in 2008 to operate as Islamic fund management firm. There are micro finance institutions operating windows of Islamic banking across Nigeria. In Islamic insurance (Takaful) significant progress has been recorded. There was introduction of Takaful products by existing conventional insurance firms such Africa alliance, Niger insurance, and Royal insurance among others. New independent Takaful firms has been established in alliance with foreign partners.

Opportunities for all categories of Islamic finance products is enormous in Nigeria with sizeable population of Muslim middle class. Nigeria boost of one of the largest population of religiously conscious people in the world according to survey by WIN/Gallup International. Like most developing countries, the number of the unbanked Nigerians is very substantial, according to The Economist magazine (International banking, May 14, 2011) about 67 million of adult population were out of formal banking system. It is believed that the introduction of Islamic banking would lead to deepening of Nigerian financial system, reducing the number of unbanked. Islamic insurance and Islamic fund management have made headways in their respective areas. Nigeria hoped to become hub of Africa's financial transactions. For Nigeria to be among the 20 largest economies in the world it must domesticate Islamic banking and finance to attract foreign investment and increase financial deepening. Nigerian banks have been listed among largest banks in Africa, operating across African countries. Lagos (Nigeria's financial capital) is the biggest 
financial centre in West Africa. There is no doubt that the potential of Islamic banking in Nigeria is enormous. Nigeria hopes to become Africa's hub of international Islamic finance transactions.

There are important things Nigerian authorities shall do to open up Nigerian market to Islamic finance. Most important is speedy introduction of legislations favorable to Islamic banking and finance, because existing legislations act as barrier to Islamic finance like Sukuk issuance. Next is creation of Islamic money market, some of the instruments traded in the money market cannot be bought by the Islamic bank. Absence of Islamic money market put Islamic financial institutions at disadvantage compared to their long established conventional competitors. Nigeria shall borrow from Malaysia on how favorable environment was provided for Islamic banks to compete with their conventional rivals. Central bank of Nigeria should as a matter of necessity collaborate with the more established countries in the field around the world; such countries include Malaysia, Bahrain, UAE, Qatar, Indonesia, Turkey, Saudi Arabia and Pakistan. Investors in Islamic finance industry (to some extent) are like their conventional counterparts; before committing money in any country they calculate risk and benefit of doing so. Nigerian monetary authorities shall consider this as they establish Nigeria as centre of Islamic finance in Africa. Enlightenment of the Nigerian public, as most Nigerians are ignorant of Islamic finance shall also be prioritized.

In 2013, the suspension of Sanusi Lamido Sanusi from his position as the governor of the Central Bank of Nigeria by Nigerian President Goodluck Jonathan and the appointment of a new governor Mr. Godwin Emefiele who was former Managing Director of Zenith Bank Plc had left many people wondering about the future of Islamic Banking and finance in Nigeria. The movement for the establishment of a fully pledge Islamic Bank (Ja'iz Bank) in the country has been on and off for almost a decade before the coming of Sanusi Lamido as CBN governor. But, it was only after he became CBN governor that the dream was realised with the starting of operation of Ja'iz Bank plc in January 2012. Before him other Central bank governors (especially Soludo) have made noises about how they wanted to see the realisation of the bank, including drafting policy documents, but up to the time they left the apex bank Islamic banking had remained on papers locked inside CBN headquarters. Now that the person who had put into practice what had been locked in the archives of the apex bank has left the bank, what is next for Islamic Banking? Which direction would it possibly take? Would its growth and dynamism be sustained looking at the controversies that trailed the establishment of the system in the last two years and the antecedent of the new governor? These are some of the questions watchers of Islamic bank in Nigeria had asked. But, these fears and moment of apprehension have come to pass, Emefiele has done well in maintaining the status quo. Mr. Emefiele has spent most of his 26 years in commercial banking business with Zenith Bank Nigeria Plc. He was not very well known outside the banking industry or known to harbor any animosity against Islamic finance. But, that is where it stops as stakeholders in the industry have to watch his move closely to see whether he will continue from where Sanusi stopped. Already Ja'iz bank plc has seen multiplications in its capital base and deposits, and has continued to open new branches on almost monthly basis leading to it becoming a national bank, from its former position of a regional bank. 
Nigeria Wealthy citizens, academics and professional bankers has not done enough for the development of Islamic banking in Nigeria. Imagine the fact that the richest man on the continent is a Muslim from Northern Nigeria, but despite that he has done little for Islamic finance because of fear of being seen as Islamic enthusiast by non-Muslims. Other wealthy Nigerian Muslims are in abundance but only handful of them has shown any desire to contribute to the field, if not for the sake of God then for the sake of profit or both. This go a long way in telling you that most of the Nigerian Muslim communities are ignorant of the workings of the system and the profitability hidden there. Studies have shown that on average Islamic banking is more profitable than conventional banks and more risk averse (Hassan and Dridi, 2010). Despite efforts to establish Islamic banks in Nigeria dating back to over two decades ago, there is only one Islamic Bank in Nigeria today. But take for example in the D8 group of nations where Nigeria is a member, all the rest of the seven members countries (including secular Turkey) has more than one Islamic Bank and their numbers is fast increasing. The reasons for the rapid growth in the Islamic financial sector in these countries are not difficult to fathom. First, the authorities have provided the enabling environment for the sector to grow; second, elites have recognized the advantages inherent in getting involve in the system; third, the general populace are being educated about the workings of the system.

Nigerian academics are slow in catching up with their counterparts around the world in the area of making scholarly contributions towards the development of the field. When compared with any other member of D8, the number of scholarly papers on Islamic economics and finance produced in Nigeria in a year is insignificant; it is not up to the volume produced by a single university in Malaysia or Pakistan. This is shameful looking at the fact that more than half of the population of Nigeria is Muslim and the fact that there are more than 30 universities in Muslim dominated states, half of them offered some economics, finance or management courses. The number of Muslim economists who are actually interested in Islamic economics and finance and are ready to contribute their quarter to the field is insignificant. Most are afraid of the field for fear of discrimination in Nigeria's highly charged labour market, where being associated with a particular religion initiative is seen as being a sensitive matter. Though, the coming on stream of Ja'iz bank has changed that perception a little bit by bringing Islamic finance into the main stream and demonstrating to the non-Muslims in Nigeria that they have nothing to fear, a lot need to be done. Among the current employees, shareholders, and customers of Ja'iz Bank Plc there are many non-Muslims who are happy to be associated with the bank and who feel at home when dealing with it.

With only one Islamic bank, two conventional banks operating a window of Islamic bank, and a Shari'ah base Mutual Fund Company, it is just the beginning of Islamic banking in Nigeria as there is more room for growth. Without the will on the part of the authorities in the apex bank the rapid growth the sector has witnessed in the recent years will be jeopardized. Hence, the need on the part of Muslim leaders in the country to make it clear to the authorities the fact that they need Islamic banking or their (Muslim) economic and religious interest will be jeopardized. Sanusi's tenure as CBN governor has done a lot in laying the foundations for the takeoff of a 
robust Islamic Banking industry; what remains is for stakeholders in the industry to insure that nobody comes and take them backward. First, the rich Nigerian Muslims should join hand together with Muslim banking professionals to establish another Islamic bank. This will ensure that unnecessary pressure is not mounted on Ja'iz and that a partner bank is provided to Ja'iz which will help to ensure that authorities provide the necessary infrastructures needed for the development of Islamic banks such as Islamic liquidity facilities. Second, more capital should be invested in Ja'iz and more Muslims should patronize the bank in order to make it more profitable and ensure that additional investors both within and outside the country bring their money to the industry.

\section{$\underline{\text { Islamic stock index }}$}

June $13^{\text {th }}, 2012$ ushered in the beginning of Islamic stock index on the Nigerian stock exchange in an agreement signed between management of the exchange and Lotus capital, a premier Islamic fund manager in Nigeria. Islamic index like any other equity index in stock exchanges around the world comprises shares of quoted companies. A unique feature of Islamic stock index is shares listed on them must conform to Shari'ah guidelines. That includes avoidance of Riba (interest), casino businesses (gambling), Alcohol, Pork making business, weapons industries, Pornography, etc. Dow Jones Islamic index is pioneer in this, it made debut in 1999 making selection of its listed stocks out of the about 5,000 listed stocks on the New York stock exchange who also conformed with Islamic ethical finance requirements. Today, there are other indexes around the global that filtered companies listed on their respective stock exchanges in order to select ones allowed by Shari'ah. Attempt was made to create a unified Islamic stock index for member countries of the organisation of Islamic cooperation (OIC). It was to provide single plat form where quoted companies on member countries exchanges (who conform with the Shari'ah guidelines) were to be selected into a global index. Like with Islamic banks, investing in the pool generated by the index is not restricted to Muslim alone. There are advantages to such Islamic index. One, it will provide avenue for stock exchanges to increase flow of investments, both from domestic and foreign investors. Two, it will provide a means of portfolio diversification and as hedge against risks common to conventional indexes. Nigerian stock exchange has entered ups and downs since the peak of the global financial crisis. The introduction of NSE-Lotus Islamic index has increased attraction of the stock exchange to investors within and outside Nigeria.

Lotus capital became the first financial firm to introduce the concept of Islamic fund management into Nigerian financial landscape back in 2008. It came as Islamic fund management firm that help Muslims and ethically conscious members of public to invest money according to dictate of Islamic law. It has become tradition worldwide for private Islamic firms to partner with exchanges or major players in the market to establish Islamic index. Prominent examples here include, BSE TASIS sharia 50 in India, Thomson Reuters Crescent Wealth Islamic Australia index, $\mathrm{MSCl}$ Islamic index, and many others. These, like I mention earlier, provide ethically conscious 
investors with avenue to invest their money. The screening criteria for selection elsewhere around the world include the percentage of interest based debt in the companies' assets, percentage of account receivable to total assets, in addition to the requirement of the main business of the firm be in line with Islamic teachings. Introduction of an ethical index into the economy is going to boost the volume of investment into Nigeria. The number of companies who do businesses according to Sharia guidelines and seeking to be listed on the exchange will increased. Since its start in 2012, the NSE-Lotus Islamic index has performed better than the Nigerian stock exchange all shares index. This is particularly more pronounce during the time of recent recession in the Nigerian economy in 2016. This state of affairs is common with Islamic indices elsewhere around the world.

\section{$\underline{\text { Islamic Businesses }}$}

Halal industry can simply be described as businesses that conduct their operation in accordance with laid down ethical procedures. It is about credibility and quality control first before any other thing else. The Halal products and services comprise broad number of sectors that cut across most of the areas of modern economy. Such businesses include banking and finance, food and beverages, hotel and tourism, education, marketing and advertising, as well as manufacturing. Thus, unlike what most people think about Halal as meaning Shari'ah or simply things made for Muslims only; Halal is universal for all people across all religions, culture and geography. In modern marketing terminology you can described Halal products as a brand group, just like when categorizing some consumer products as for Western, Asian, or Latin consumers, but still being consumed by people in Africa, Middle East and Eastern Europe. Hence, the label Halal does not mean only for Muslims in Nigeria but also for Christians, Jews, and adherent of other religions living in Nigeria and Africa. Already there is vast market for these product categories. For example, most of the meat been consumed in Nigeria is Halal meat. An average Southern Christian buys his meat from a Hausa Muslim meat seller who follow Halal procedure of killing and preparing an animal for consumption. Halal means ethical, sustainable, environmentally- and socially-responsible goods and services. According to CNN's Sophie MorlinYron,"You might think of halal as just being a set of Islamic rules about meat, but the global halal industry incorporates everything from medicines to cosmetics. And the industry is growing fast." Already some products imported into the Nigerian market from Indonesia and Malaysia have Halal brand on them and being consumed by both Muslims and non-Muslims. These include in the product categories like soap, tea, oil, and noodles. According to the Global Islamic Economy report 2016/17 "Major global food suppliers such as BRF from Brazil to top global food processor Nestle, to top retailers Carrefour, Walmart, and Whole Foods have all significantly engaged in the Halal Food market. MasterCard has launched a Halal benefits program for its Shari'ah-compliant card holders in Southeast Asia. In travel, many major hotel operators (IHG Group, Marriot, Fairmont) among others are ensuring they create experiences that fit some of the unique requirements of Muslim leisure travelers". 
In Malaysia, the government has created what they called Halal Industry Development Corporation charged with the responsibility of ensuring the integration and comprehensive development of their national Halal industry. Its functions included focusing on the development of "halal standards, branding and promotion, and commercial development of halal products and services". It is the first of its kind in the world, established in 2006. Today many countries are following in its footsteps in order to tap the growing Halal market that was put at \$2.3 Trillions. The annual grow of the Halal market around the world was estimated by World Islamic Economic Forum as $8 \%$. In particular Dubai in UAE has gone far in this direction as it aspires to become global hub of Halal economy. Thus for those who are making noise about Islamic banking in Nigeria, but cannot restraint themselves from going to Dubai to enjoy the luxury of modern world this is a challenge for them. Because Halal does not mean for Muslims only, but humanity at large. Just like New York, London, Paris, Tokyo and Hong Kong welcome everyone, Dubai, Istanbul and Kuala Lumpur do the same thing despite their aspirations to become centers of the global Islamic economy. Countries such as China, UK, Thailand and South Africa are doing everything possible to become global exporters of Halal products and services such as beverages, cosmetics, pharmaceuticals, travel and tourism as well as financial services. In Europe alone it is estimated that the market is growing at the rate of $10-20 \%$. Brunei has achieved some level of success in exporting its Halal certified products into Europe and gradually the products are getting acceptance in other parts of the world. As Nigerian government is eager to attract foreign investors into the country, federal government shall include Halal industry in its strategy. It can start by creating Halal tourism industry and invite tourist from everywhere to Nigeria. There is also exportation of Halal meat as Nigeria is a big producer and consumer of animal products in Africa. Nigeria can become the 'Holland' of Halal diary and meat in the world looking at the potentials in this sector. Australia, despite not being a Muslim country, is one of the top exporters of Halal products mainly meat. Nigeria can as well export Halal meat to Middle East, especially Saudi Arabia and UAE. Brazil is another important exporter of Halal products. Singapore is one of the top destinations for Halal tourism and travels. China is important in production of Halal fashion products, while UK, France and Germany in Halal media and recreation.

\section{Contributors to development of Islamic economics, banking and finance}

\section{SANUSI LAMIDO SANUSI - former governor, Central Bank of Nigeria}

As central Bank governor Sanusi played the most important role that led to the starting of operations of Ja'iz Bank, the first fully fledge Islamic Bank in Nigeria; by removing obstacles to its take up. The move to establish an Islamic Bank in Nigeria has been on and off for three decades, but it was only in January 2012 that a registered Islamic bank opened its doors to the general public and the credit for that should (among others) goes to Sanusi. This is because past Central Bank governors were not as serious with the creation of Islamic Banking landscape as Sanusi. Soludo has promised to introduce non-interest banking into Nigerian banking landscape but up to the time he left office Islamic Banking existed only on papers lock inside CBN. In addition to 
facilitating the starting up of operation of Ja'iz Bank Plc, Sanusi pushed Nigerian authorities to issue its first SUKUK Bond, already Osun state in South West of Nigeria has kicked started the process of issuing first Sukuk (Islamic Bond) by a state in Nigeria. Sanusi also played an important role in the establishment of International Institute of Islamic banking and finance in Bayero university Kano. In recognition of his contributions he was awarded with a global Islamic banking and finance award.

\section{ALHAJI UMAR MUTALLAB - Chairman, Ja'iz Bank Nigeria PIC}

One of the pioneers that championed the establishment of Ja'iz Bank where he served as its pioneer chairman. Before that position he was the chairman of First Bank of Nigeria Plc, the Nation's oldest and biggest bank, as well as UBA where he served as Managing Director. As a very wealthy person in Nigeria he has used part of his wealth to invest in Islamic finance with the view to see the actualization of the old dream of establishing Islamic Banks in Nigeria. He and the management of the bank pursued the vision of transforming Ja'iz bank into the biggest Islamic Bank in Sub Saharan Africa.

\section{HAJIA HAJARA FOLA ADEOLA - CEO, LOTUS CAPITAL NIGERIA PIC}

Adeola is behind Nigeria first Halal capital management fund, which came on stream in 2008. Before that period there was no any company that fully served the Islamic fund management industry. Today Lotus capital is very active in the Nigerian capital market. It lunched, together with the management of Nigerian stock exchange, Nigeria's first Islamic Share Index. Now more than six years since the formal lunch of the Index, it has recorded an impressive performance. Since its establishment some ten years ago, Lotus capital has seen grow in its businesses, making it very active in the Nigerian capital market. She has also contributed to the nationwide movements for the development of Islamic financial sector in Nigeria, through input in major government policy drafts.

\section{PROFESSOR MUHAMMAD LAWAL AHMED BASHAR - Usman Danfodio University, Sokoto}

Bashar was among the few academic scholars in the 1980s that championed serious academic work in the field of Islamic Economics in Nigerian Universities. His PhD thesis written under the supervision of Professor Mohammed Najatullah Siddiqi and Monzer Kahf has made contributions in the field of public utilities under Islamic system. He has contributed scholarly papers to main Islamic economics journals around the World. He and late Sule Ahmed Gusau have contributed to the development of manpower for the former Habib Bank Nigeria plc. He serves as Shari'ah adviser to both Ja'iz Bank Nigeria plc and Lotus Capital plc. He was involved in 
the building process of Ja'iz Bank Plc right from the beginning of the move for the establishment of the Islamic Bank.

\section{LATE SULE AHMED GUSAU (PHD) - Usman Danfodio University, Sokoto}

Sule Ahmed Gusau of bless memory has made contributions to the development of Islamic Economics, Banking, and Finance in Nigeria. He was active in the process that led to the Islamization of economics courses at Usman Danfodio University Sokoto. His books and papers were used as reference materials in and outside of Nigeria. He was particularly very active in the movements and groups (since 1980s) that wanted the establishment of Islamic banks in Nigeria. He helped in the training of the next generation of Islamic Economics enthusiasts in Nigeria. Sule Ahmed Gusau and other enthusiasts for Islamic Economics and finance remained steadfast at a period when few people have confidence in the area, a time when little was known about Islamic Economics, Banking and Finance in Nigeria. He has contributed papers on Islamic Economics (particularly Zakah) in conferences in and outside of Nigeria.

LATE ALHAJI ABDULLATEEF ADEGBITI - Former Secretary, Nigerian Supreme Council for Islamic Affairs (NSCIA)

He was part of the pioneering team that supported the creation of Ja'iz Bank Nigeria Plc. Late Alhaji Adegbiti was very passionate about Islamic finance, he contributed to the actualization of Ja'iz bank both by his physical presence and capital. He has participated in setting up of conferences that help kept the fire of Islamic finance burning, when others had given up. His contributions to the development of Islam in Nigeria cannot be overemphasized. He served as patron to Zakat foundations in the South west of the country as well as contributed to the development of Islamic education in Nigeria.

\section{ALHAJI FALALU BELLO - former MD, Unity Bank Nigeria plc}

He is pioneer in the field of Islamic banking operation in Nigerian right from his days as Managing Director of former Habib Bank Nigeria Plc, which started the first window of Islamic Banking by any conventional bank in the country. He continued with his interest in Islamic Banking and finance even when he left Habib Bank. He was part of the pioneers that help set up Ja'iz bank of Nigeria. He has made inputs in many government drafts on the development Islamic Banking in Nigeria. At Unity Bank, he started the process of opening Islamic Banking window in the bank. 
ALHAJI UMARU IBRAHIM -Chief Executive Officer, Nigeria Deposit Insurance Corporation (NDIC)

He championed the introduction of programs for insuring non interest (Islamic) banks in Nigeria. The primary function of Nigerian Deposit Insurance Corporation is to insure Nigeria's banks' depositors against the risk of collapse of these banks. Before this time there was no any arrangement on the ground to protect depositors of Islamic Banks in the country. He has been very supportive of efforts to train manpower on Islamic banking and finance within NDIC, including staff trainings abroad. His collaboration with the management of CBN towards the development of Islamic banking in Nigeria is unique in itself.

\section{LATE PROFESSOR MAHDI ADAMU NGASKI - Former VC, Usman Danfodio University Sokoto}

He spearheaded the Islamization of academic courses offered at Usman Danfodio University Sokoto in the 1980s, the first time by any university in Nigeria. The major beneficiary of this was the Economic Department of the university. In 1985 Usman Danfodio University Sokoto under his leadership organized the first International conference on Islamic Economics on Nigerian soil that attracted the Who's Who of Islamic Economics in the world at the period. Because of his Islamization efforts at the university, he was rewarded with the Vice Chancellorship of International Islamic University Uganda after the expiration of his tenure in Usman Danfodio University Sokoto. As VC of Usman Danfodio University Sokoto, he championed the training of manpower on Islamic Economics leading to PhDs in the field, and that of the fields of Islamic accounting and Management.

\section{INTERNATIONAL INSTITUTE OF ISLAMIC THOUGHT (IIIT), Nigerian Office, BUK}

IIIT, as it is widely known, has contributed in rising awareness between university academicians on revitalization of Islamic knowledge in the modern era. The office of IIIT was previously located at Usman Dan Fodio university Sokoto before it was later moved to Bayero University Kano because of the central location of Kano and its fame in Islamic scholarship. The institute has contributed in publishing books, journals and reports on Islamisation of knowledge in Nigeria. It has organized local and international conferences in conjunctions with universities and organisations in and outside Nigeria. It is supported by its parent body with headquarters in the United States of America. 
ALHAJI MOHAMMED BINTUBE - Pioneer MD, Ja'iz Bank Nigeria plc

Alhaji Mohammed Bintube was the pioneer Managing Director of Ja'iz Bank Plc right from the initial public offering of shares of the bank in 2003. He piloted the affairs of the bank for ten years including the period when the bank did not start day to day operations. He left the bank after reaching ten years at the helm. He has participated and helped in organizing conferences on Islamic Banking in Nigeria. As a result of his efforts and that of other members of Ja'iz team, foreign investors were wooed into investing in the bank; particularly the Jeddah based Islamic Development Bank. He made wide ranging inputs into government formulation of policies for Islamic finance in Nigeria.

ISMAIL M. ZAKARI - Partner, Zakari and Co. Chartered Accountants

His accounting firm, Zakari and Co. pioneered Islamic accounting practice in Nigeria. His company has in the last one and half decades helped organized a number of international conferences on Islamic Banking in Nigeria; as well as in the area of manpower training for the nascent field of Islamic finance. His company is the accounting firm for the two major corporate Islamic finance institutions in Nigeria: Ja'iz Bank Plc and Lotus Capital Plc. His dream of seeing to the actualization of Islamic finance in Nigeria has taken him to many countries around the world.

\section{INTERNATIONAL INSTITUTE OF ISLAMIC BANKING AND FINANCE, BUK Kano}

This institute came into being in 2013 through efforts by the management of Bayero University Kano (BUK) with support from the then CBN governor Sanusi Lamido Sanusi. It was established to help in training of manpower in the area of Islamic Banking and finance in Nigeria. It is first of its kind in West African sub region. The institute has collaborated with Islamic research and training Institute of Islamic Development Bank Jeddah in hosting international conferences in the field. The institute has been running masters and sub degree programs in the field of Islamic banking and finance in Nigeria.

\section{MALAM BASHIR ALIYU UMAR (PHD) - Shari'ah Adviser to the CBN Governor}

Bashir Aliyu Umar is an Islamic scholar who has contributed to efforts by CBN to develop Islamic Banking in Nigeria. As the Shari'ah adviser to the apex bank governor he has helped in formulating documents that guide Central Bank of Nigeria's regulation of the Islamic finance industry. He has contributed also in advising other regulatory agencies such Security and Exchange Commission (SEC) and Nigeria Deposit Insurance Corporation (NDIC) on Shari'ah rulings pertaining Islamic Banking and finance. As Islamic scholar he preaches on Islamic Banking and 
finances to his numerous followers both during Friday sermons in his Juma'at mosque and lectures.

$\underline{\text { Islamic economics and finance in Nigerian universities }}$

The first international seminar on Islamic Economics in Nigeria was hosted by University of Sokoto (today called Usman Dan Fodio University) in 1985 attracting who's who in Islamic Economics. That conference served as formal introduction of Islamic Economics into Nigerian University system. After the conference, University of Sokoto added Islamic Economics to its undergraduate and postgraduate economics programs. The university also sent its economic and management departments staffs abroad to train at both masters and PhD level on the subject. PhD candidates were sent for short trainings in the International centre for research in Islamic Economic, Jeddah Saudi Arabia, and Islamabad Pakistan. Those pursuing masters were send to International Islamic University, Malaysia. There were then efforts by Organisation for Islamic Conference (OIC) to establish an Islamic University in Nigeria, but that effort was frustrated by forces within the Nigerian government system. The responsibility for introduction of the Islamic economic system into Nigeria was left on universities such as University of Sokoto and Bayero University Kano. Usman Dan fodio university Sokoto was then, jokingly, referred to as an Islamic University. Changes were made in laws establishing the school to make it possible to accommodate these programs. Later other Universities started to introduce Islamic economic programs. These pioneers of the Islamization process got inspiration from Sokoto caliphate (1811-1904). Hence, the renaming of the University of Sokoto to Usman Dan Fodio University, Sokoto. The second Vice Chancellor of the school, Professor Mahdi Adamu Ngaski spearheaded the changes that allowed introduction of Islamic economics. Leading the Islamization process was the department of Economics, followed by Management science, political science and sociology. The university has produced PhD holders in Islamic Economics and Finance, accounting and management more than any other university in Nigeria. Late Dr. Sule Ahmed Gusau, Professors M.L.A. Bashar and K. K. Kamaluddeen were pioneering Islamic economists and accountant (in the case of K.K. Kamaluddeen) from the university.

Bayero University Kano has also introduced post graduate programs in Islamic finance. The establishment of international Institute for Islamic banking and finance by BUK authorities made the running of postgraduate programs in Islamic banking and finance possible. Central Bank of Nigeria under Sanusi Lamido started the building of a multibillion Naira site for the centre within the school premises. Today, BUK more than any other university is spearheading the training of manpower in Islamic Banking and finance in Nigeria. University of Maiduguri has a long interest in starting programs in Islamic Economics and finance. In 1989, it co-hosted with Usman Dan Fodio University Sokoto and Bayero University Kano an international conference on nature and Methodology of Islamic Economics. In Ahmadu Bello University (ABU) Zaria there were no serious changes introduced in their economic syllabus to incorporate Islamic Economics. But, an institute was established in the school to run certificates and diplomas in Islamic finance. The institute was 
established in collaboration with a former staff of Habib Bank Nigeria plc (Alhaji Aminu Dutsinma) who was in charge of the bank Islamic banking section. Islamic economics and finance course is offered to graduates of religious study of University of Ilorin. Three Islam inclined universities, Katsina University, Katsina, Al-Hikma University, Ilorin, and Crescent University, Abeokuta, ideally should have led the Islamization process but that has not been the case. With the establishment of Islamic finance institutions in Nigeria, the future prospect of graduates with qualifications in Islamic economics and finance is bright. There will be huge demands for advisers and experts on Islamic finance. Worldwide the grow in the Islamic finance industry is in double digit, hence, the foresight of educational planners in advance economies such as the UK, France, Spain, US, Switzerland and Germany that started the programs in this field. The grow in demand for experts in Islamic finance will afford Nigerians with the right qualifications the chance to work in the field in countries such as Malaysia, Dubai, Bahrain, and Saudi Arabia.

\section{Media and Islamic banking}

Though, Islamic banking is not a new phenomenon as its introduction in countries around the world date back to 1950s, its appearance in Nigeria generated a lot of controversies and heated debates, most of them as a result of negative media coverage given to the program. Islamic banking did not call for annihilation of other systems or stopping of followers of rival systems from following their beliefs. But, from the oppositions at the start of the banking model in Nigeria, one would have thought that was what Islamic banking called for. Nigerian media, since independence, has been divided along ethnic and religious divides, North-South. The Northern media anchored Northern cultural conservatism, Islam and perceived political dominance. The Southern media amplified South assumed superior way of life, Western-liberal style way of life, and perceived economic dominance. The introduction of Islamic banking with its links to North should not, therefore, be expected to escape this historical divide. The Southern media is in the fore front of those trying to show the weakness of Islamic banking to the world. For example, when a columnist in Punch, Vanguard, or Tribune said Islamic banking was plot to Islamize Nigeria, you should understand why he said that. The word 'Islamic' prefix to the name of the banking model was assumed to mean absence of benefit to Christians. But, this has not been true, beneficiaries of Islamic development bank programs in Nigeria included Christian states. Nigerian media must learn to see Islamic banking and finance in positive light considering its appeal to the largest segment of Nigerian population. Nigerian media industry must learn from other countries around the world on coverage of Islamic banking programs. National interests shall always be top priority over sentiments. But, now over six years since the introduction of the banking system, Nigerian media is gradually accepting the banking model just like all other types of banking models. 


\section{NIGERIA AND THE REST OF THE WORLD}

\section{$\underline{\text { World Trade }}$}

No country in the world can be defined as an island to itself, as every country in the world trade with others through selling commodities or services to them and buying other commodities and services from them. Nigeria can be described as a mono-economy that depended solely on the exportation of crude oil to the rest of the world for most of its foreign exchange, while at the same time importing everything from car to cotton underwear. Thus, contribution of Nigeria to globalization virtually amount to its position as a consumer nation that supply raw materials to more serious economies around the world. From this vintage point one can see some of the causes of Nigeria's predicament i.e. 'when you consumed more than you produced'. This was what Buhari government has being battling to correct through emphasis on reduction in importation and localization of productions. The collapse of crude oil price clearly exposed Nigeria precarious balance of payment position and the subsequent deflation in foreign reserve position. Thus, Nigeria has negative balance or rather operated with a trade deficit. Unlike the Gulf oil producing nations who have very large savings which they fall on when oil price collapsed, Nigeria as at the time Buhari came to power had no such luxury, but depended on borrowing from other nations in order to balance the deficit in its trade with the rest of the world. As many commentators have observed, it was the spending spree of the PDP years in power that brought Nigeria to where it was in 2016 when it officially entered recession. Had it been previous governments have saved for rainy days, Nigeria would not be in recession.

One does not know what happens to Nigeria priorities, in term of its foreign relations which previously had Africa as its focus. Did Nigeria have its foreign trade equivalence in all these years? Figures from NBS showed Nigeria traded more with countries outside Africa than with African countries. If Nigeria could remedy this and focus on Africa it would go a long way in changing her economic fundamentals from consumer nation to producer nation. Because with Nigeria relatively low industrial base she could be able to supply African countries with some of the things they needed. If China, which had been the second largest economy in the world, started this way by producing first for its Asian neighbors before others, why not Nigeria. Nigerian real interest rate was higher than the average real interest rate in her main trading partners which means that Nigeria was a net importer of capital from these countries. But, international capital did not move freely as domestic capital did, it took time and came with stringent conditions attached. Thus, 
when the Chinese said they would lend Nigeria some ten billion dollars to finance railways and energy infrastructure, Nigeria should remember that there were conditions attached that included buying the equipment needed for the projects from Chinese manufacturers, using Chinese companies for the project, employing Chinese labour and the interest rate charged on the loan was higher than what Chinese banks charged their domestic borrowers back home in china. In short, China was using its foreign loans to find markets for its exports. Another negative side of Nigeria precarious position was that nations that agree to lend Nigeria money did so charging premium for the risk of default of doing that, taking into consideration international credit ratings provided by rating agencies such as S\&P, Fitch and others.

With high domestic interest rate in Nigeria, it was difficult for any domestic investor to borrow and invest profitably without some assistance from the federal government in, for example, imposing higher tariffs on imported commodities from abroad that competed with locally produced goods. But, this also came with its own negative side effects in term of higher inflation; thus, more worries for domestic consumers of the same commodities who were used to cheaper alternatives from China and other low cost countries. Another incentive for local producers was where government reduce the amount of tax paid by certain industries that were considered strategic in the economy. Specifically, tariff policy should be used by the Buhari government to attract foreign producers into Nigeria in order to establish local production plants to replace those being imported. Nigeria had failed to take advantage of its abundant cheap labour and lunch itself as Africa's cheap labour alternative to Asian producers, but instead continued to depend on oil which was not sustainable, more especially with increased agitations from oil producing states in the Niger Delta. Everywhere around the world, oil producing nations from Saudi Arabia to Russia have come to the conclusion that their future did not depend on oil. This explain Saudi authorities change of direction through emphasis industrialization, tourism, and service industries. In this kind of atmosphere, the best thing for Nigerian government to do is to put things in place for possible attraction of foreign investors in order to bridge the gap created by low investment in the domestic economy. But, central in that arrangement was getting foreign exchange right first, which was not in a good shape to perform that function. No foreign investor invested his money where he was not confidence about the country's foreign exchange regime.

Foreign Direct investment (FDI) has played important role in the growth and development of developed and emerging economies of today. US itself could not be where it is without contribution of businessmen from Europe during its early history. The same thing goes with China in the 1980s and 1990s after opening its doors to the world, substantial foreign direct investment came from Chinese residing in Taiwan, Hong Kong, Philippines, Indonesia, Malaysia as well as from Japan and South Korea. Every country has at one time or the other protected certain sectors of its economy from competition coming from abroad. Before now, Nigeria virtually have no any active policy in place to protect its local industries apart from the localisation policies of the 1970s and early $80 \mathrm{~s}$. This turn of event become worst after return to democracy in 1999, as elected leaders fear backlash from their citizens for putting protectionist policy that would lead to increase in price and reduction in welfare. While over the last three decades, Nigeria has failed 
to establish itself as an exporting country. But, Nigeria had become very good at exporting one commodity, i.e. Labour. It was estimated that there were hundred thousands of Nigerian expatriates working in North America, Europe and Middle East as at 2017. While the remittances they have been sending home serve as important source of foreign exchange in periods of scarcity of Forex in Nigeria, on the other hand their absence had deprived Nigeria of needed human resources to achieve rapid economic growth and development. This particular issue have been the genesis of the growing market in health tourism, foreign education, and capital exportation out of Nigeria that have contributed to deterioration in the value of Naira against world major currencies.

The rate of inflation was not sustainable as it eroded gains the government wanted to achieve in term of encouraging domestic production and exportation. The simple true here is that higher inflation meant foreign countries who wanted to purchase made in Nigeria goods found it expensive relative to other countries like China. While domestic consumers found Nigerian goods expensive compare to those imported from abroad. This is why it was important for Nigeria to be careful in fixing its foreign exchange rate to avoid scenario where it achieved opposite effect of what it intends to achieve. There were empirical evidences that linked higher inflation with depreciating currencies around the world. Hence, CBN should watch over inflation as at the same time it tried to stabilizes Naira. At this point one is forced to ask the question what happened to Nigeria previous priorities of focusing on agro-allied industry as its export base? A simple visit to Bompai, Sharada and Challawa industrial estates in Kano state left one stun. There were hundreds of closed plants in the three locations that (before they stopped production) specialised in production of agro-allied products for Nigeria markets and neighbouring countries. But later they were closed down because they could not compete with imported commodities that flooded markets. Like it was mentioned before, with high interest rate, poor roads, lack of power and unfavourable government policies of the last three decades there was no way these industries would have survived. Thus, as Buhari government tried to build roads, power plants, railways and new airports, it must have these industries in mind. Particularly, how reforms connect to the issue of reviving manufacturing sector?

The point I have been trying to make shall be clear by now. That Nigeria as exporter of primary products, with declining international price relative to final output they were processed into, would fallen behind those countries who purchased raw materials from her and turned them into finished output. Raw materials, in themselves, constituted small part of total monetary value of inputs into production of outputs. At the end, the amount of money Nigeria received from selling her primary products would be lower than the amount she paid for her imports. under this scenario, Nigeria had no other alternative than to start producing those imported products herself as it was cheaper to produce locally than imported, taking into consideration the deterioration in her term of trade. This is how countries like China, South Korea and Brazil moved away from being primary producers to manufacturing power houses with active government support to private sector producers. These countries put local companies first before firms from other countries. In Nigeria, if not of recent, foreign companies were given preferential treatment 
over their domestic rivals. Look at Nigeria West African neighbour (Ghana), which in recent years was able to attract manufacturers away from Nigeria despite small size of her domestic market compare with Nigeria. At the heart of the attraction of Ghana to manufacturers over Nigeria were combined impact of business friendly policies, constant power supply, good infrastructures, and political stability. These factors persuaded many foreign firms to move their head offices from Nigeria to Ghana from where they exported their finish goods back to Nigeria. The size of Nigerian market in Africa was enough to give Nigerian government bargaining power over any foreign investor coming to Africa who wanted to enter Nigerian market. One of such conditions must be that before any foreign businessman is allowed access into the Nigerian market she/he must establish plants in Nigeria.

The rallying point for the East Asian countries that facilitated their rapid economic growth was 'export push strategy'. Among other factors, the East Asian success stories pushed for macroeconomic stability and low inflation; they also avoided deficit financing at some stages of their development story. They did all they could to accelerate export including using preferential treatments, soft credits, protectionist policies, currency devaluation. Buhari government aim at reviving the economy should not just stop at supporting local firms to produce for domestic consumption but must include export push as done by the East Asian success stories. In both the developed and emerging economies, one barometer widely used to measure health of an economy was export. Export was the heart of German economic leadership of the Euro area economy, likewise the extraordinary performances of both Japanese and Chinese economies. We could barrow a leaf from both the US and Germany where states and regions had specialised in exportation of specific commodities and services. In Nigeria, for example, Kano should start by exporting Agro-allied products such as processed foods, Shoes, and Garments as well as retails services; Lagos could specialised in exportation of financial services, and electronics; while Port Harcourt specialised in petrochemicals and shipping services. Federal government must find ways to rekindle export rivalry between the 36 states of the federation including allocating export quotas to be filled by each state. The main difference between the economic strategy of China and India from 1980 to 2010 was very clear to the observers of the region; while China aggressively pushed export growth, India on the other hand emphasized producing for its domestic market. Today we all know who emerged the winner, China has moved hundreds of millions of its citizens out of poverty while India's population remained one of the poorest in the world.

The case of Japan and South Korea is worth mentioning here, these two countries were not very much endowed with natural wealth like most African countries, but that notwithstanding they were able to import the raw materials they needed, processed them into finish goods and exported them. There example was a case of what has been called 'forced growth'. In the case of South Korea, at the end of the Korean wars that led to the creation of today's North and South Korea, almost all the industrial capacity of the Korean nation before partition were located in the North. Thus, after the war South Korea was left with nothing but agricultural lands; but now compare where the two countries are today - South Korea is a developed economy while the 
North is a developing economy. Innovation and entrepreneurship were the center of Israel successes over the last decades. Small firms that were established as startups with contributions from academia, military, and business later turned to become export power houses, exporting everything from security software, microchips, to agricultural outputs. The successes of the US in information technology can rightly be linked to small businesses (startups) established in Silicon Valley in the 1970s and 1980s. In the last two decades, these startups have become the engine of US economic growth, accounting for large percentage of total US exports to the rest of the world. The great Austrian economist Joseph Schumpeter, for example, saw economic development as synonyms with innovation, without technological innovation there would be no development. But, the kind of development Schumpeter was talking about could only be actively promoted by a serious government, which has been the case in the US, Israel, Taiwan, South Korea, Denmark and many other developed nations. Schumpeter also emphasized the role played by entrepreneur in all these, as the innovator that made it all happened. Thus, at the end everyone would see that entrepreneurs were the back bone of export growth around the world.

In most times, in the management of foreign exchange, it was much easier and practicable to use manage float than fixed exchange rate system, as it was not easy to know the actual rate that brought both internal and external markets into equilibrium. The amount of human and material resources that would be devoted to the task of determining fixed exchange rate would then be put elsewhere in the interest of the economy progress. Multiple exchange rates did no good, CBN should go for single exchange rate for every one with interest in Forex. Multiple exchange rates encouraged corruption and inefficiency. Some of the problems Nigeria was having with foreign exchange could be linked to activities of speculators who hoarded Dollar thinking they understood very well the mind game of Buhari and his economic advisers. As discoveries by EFCC and other security agencies have shown, a lot of Nigerian elites had buried millions of Dollars somewhere in their houses, farms, and other properties' sites; which contributed in no small way to the scarcity of Dollar Nigeria faced. Nigerian banks could not be said to be innocence party in the speculative attacks on Naira, either on their own or in collaboration with some powerful elites. Nigerian banks have been working to undermine Naira to their own advantage. We all remember what happened during former President Babangida military regime's deregulation of the economy, when virtually all Nigeria banks abundant their primary assignments and became overnight Bureau De changes. But no matter what, Buhari government must also control inflation in order to establish the needed economic stability for healthy economic growth. CBN must double on it current effort to subdue inflation including stabilizing the foreign exchange market and reduction in interest rate. Buhari government push to overhaul the agricultural sector should be encouraged. Agricultural export should provide short term solution to over dependence on crude oil export. 


\section{Economy and Trade in Africa}

There have been discussions in both media and academia about the potentials of African economy to follow in the foot steps of East Asia economy and join the league of so-called 'miracle' economies. Over the last few years the African continent has grown at an average rate of about 3-5\% despite the challenges that crippled growth on the continent. Top of these challenges are continued war in parts of the continent, death of infrastructures, lack of skill man power, political instability and dictatorship, poverty and famine, lack of coordination, poor planning and absence of continuity in government policies. But, that notwithstanding Africa has the potentials to rival Asia as the next global economy engine of growth. With a population of about one billion people, though less than the population of China, alone, Africa has the potential manpower and consumers to drive the next era of global growth. Already, economies of South Africa, Nigeria, Ethiopia and Egypt have a combine GDP of nearly \$1.5 trillion, which if they were to be one country they would be the $12^{\text {th }}$ largest economy in the world. In the last decades the average inflation rate of the continent had come down from $22 \%$ in the 1990 s to $8 \%$ of the last 10 years, according to the economist (2012); as a result of improvements in the macroeconomic management adopted by these countries. The same thing can be said of the debt overhang in the continent as the overall debt has come down by a quarter in the last decade. Today, the number of countries that practice some kind of democracy in Africa are in the majority compared with 20 years back. The third largest economy on the continent, Egypt had elected its first democratically elected civilian president in its history. Though, the Egyptian experiment was short-lived due to a military coup a year later. The era of military dictatorship on the continent is over, and looking at the available statistic on the ground the era of poverty and underdevelopment that characterized the continent would follow to become history.

In the last 10 years, the performance of the continent had slow down due to events in North Africa, falls in the price of raw materials export and increase in violence across the continent, but looking at performance of sub Saharan Africa alone, its growth was impressive at an average of $5 \%$. But, with most of the revolutionary events in North Africa about to be over, the performance of the continent shall peak up. As the BRIC economies, Europe and East Asia continued with quest for resources, so would the export earnings of mineral resources rich countries in Africa. Already poor economies such as Niger who had been ravaged by famine over many years have started to feel the impact of Chinese investors, as they helped to build the country's first oil refinery that refined its discovered oil deposits. Over the last few years (2010-2013), Nigerien economy has grown at a high growth rate, and according to estimates from African economic outlook; it was expected to be one of the fastest growing economies on the continent. Resources rich economies such as Angola and Libya would continue to grow, despite setbacks in the case of Libya in which case if things change for good it is going to be a blessing and put the country among the shining examples of modern African countries. Ethiopia and Rwanda have become the continent role models in term of macroeconomic prudence, despite their apparent difficult situations they have 
managed to grow at a higher rate pulling many of their citizens out of poverty. The kingdom of Morocco continued to increase her competitiveness and attraction to the outside world with the lunching of ultra-modern plants by major manufacturers in Europe who take advantage of the country proximity to Europe, low cost labour and tax holidays provided by the country. In term of political stability, the continent still has a long way to go with wars going on in Mali, Sudan, Somalia, Congo, and corrupt regimes everywhere around the continent. The African Union has a lot to do in changing how the world view the continent. Chinese companies have been very active in building modern infrastructures, though global commentators are calling for caution in the manner African countries are accumulating Chinese debt to build infrastructures.

According to the Economist of $3^{\text {rd }}$ December, 2011, Africa as a region grew consistently faster than any other region in the world. This is another testimony to the other reports that see Africa as the next global power house. Unlike two decades earlier when the rest of the world viewed Africa as a kind of basket case. Ghanaian economy is one of the fastest growing economies on the continent, attracting billions of dollars annually in form of foreign direct investments. With GDP of about $\$ 40$ billion, though, small when compare to Nigeria or South Africa, looking at the size of the population, the country was doing well and had succeeded in pulling out millions out of poverty. The number of middle class in Africa has grown fast between 2002 to 2012, with this development market for western-style consumer goods would be vast and with it the dynamism of the African economies would increase. Trade between Africa and the rest of the world continued to increase at much higher rate than what obtained a decade earlier. Some of the biggest economies on the continent like Nigeria, South Africa and Egypt boasted of good financial infrastructures like well capitalized banks and emerging capital market. Nigerian economy is expected to grow after a brief period of recession. Mobile phone penetration in Africa was growing at an increasing rate, according to some estimates there were about 600 million phones in Africa, making the telecommunication sector one of the profitable sectors on the continent. After the general elections that brought the Muslim brotherhood candidate Muhammad Mursi to power, Egyptian economy had been expected to bounce back and followed in the footsteps of Turkey, another Middle Eastern power with moderate Islamist in power. Turkey, for example, has alienated all fears about the moderate Islamists holding of political power, it is today one of the biggest economies in the world. But, the military coup that ousted the elected government in Egypt has turned things upside down. Egyptian economy has been suffering due to reductions in the number foreign tourists coming to the country, declining exports and fall in foreign direct investments. Inflation and interest rates have increased; the number of poor people in the country has also increased. The regime of military strongman Sisi has to rely on handouts from the gulf monarchies in order to survive.

The past global economic crisis that made working conditions in advanced economics difficult was responsible for the return of expatriates of African origin back to the continent to contribute their quarters to the development of their countries. This had for a short time provided the continent with the much needed skilled manpower required to push the frontiers of the region's growth. These combine with the existing skill manpower helped the growth of sectors such as 
telecommunications, IT, services, and manufacturing. Despite, negatives effects of last global economic crisis on the world economy, in some other ways, it had really provided the continent with opportunities, for example, the growing attractiveness of African bonds compare to bonds that come from the developed countries. Many investors kin on diversifying their investments from the highly toxic assets that led to the last global crisis are moving towards Africa. As a result, the stock markets of South Africa, Egypt, Nigeria, Kenya, and Ghana were receiving a lot of foreign inflows. To tell you how rewarding investing in Africa has been in recent years, the richest person on the continent, Aliko Dangote, has made most of his wealth in Africa. He had planned to make his cement-making empire one of the largest in the world, with the planned listing of the company on the London stock exchange, and further expansions into other African countries. Other African companies, such as South Africa's telecommunication giant MTN that has invested widely across the continent, have also invested in other places around the world more especially in the Middle Eastern region with its presence in Iran. Africa is indeed an aspiring economic power house yet to develop it potentials. As other parts of the world exhausted their naturally endowed resources, Africa waited as the spare tyre of world economic growth machine. But, as I mentioned elsewhere, Africa has to put its house in order first before it can realise all these opportunities.

In the past, global debt crises had cost political leaders such as Greece's and Italy's their jobs. After the most awaited relieves from debt overhang of the late 1990s to early 2000s, Argentina has recently found herself in another debt inspired economic crisis. The Greece debt crisis was one of the most devastating since third world debt crisis of the 1980s, its impacts had concentrated on the developed countries of Western Europe and North America. African countries, like most other developing countries, have had their own share of debt crisis in the past and many were yet to recover from the blow to their nascent economic growth. The blow that African nations received was indirect, since the debt in effect was European sovereign debt. Channels through which global turmoil affected African economies are trade and financial movements such as portfolio investments as well as reduction in total remittances coming to the continent. At the height of the Greece debt crisis, the bulk of African exports to European countries were affected by way of reduction in the overall export especially primary products. Countries such as Kenya, Mali, Uganda, and Senegal had seen their primary export to Europe affected by the crisis. As austerity measures put in place in countries such as Spain, Ireland, and Portugal bit harder so should the volume of trade between these places and their African partners. Debt crisis of Greece's magnitude should be expected to have an effect on corresponding debt hold by African countries. The cost of borrowing had increased making it more difficult for poor African countries to finance their deficits. Many countries across Africa started to rethinking their decisions to issue bonds or borrow from multinational financial corporations. But one positive way the developed countries economic crisis affected Africa was by way of directing attention of global financial players toward Africa. In order to satisfy the demands of portfolio diversification, many global investors were directing their money toward African debt markets which were young, dynamic and diverse. The most recent economic issue 
that is coming from Europe after the Greece debt crisis is Brexit. The Britain withdrawal from the European union may have both positive and negative repercussions for the continent of Africa.

China, with foreign reserve running into trillions of dollars, has been christened by analysts as the lender of last resort in crises periods. African countries with their own crisis of lack of investments and poor infrastructures have increasingly relied on china to come to their aid. In the recent past, Chinese government and business community have bought billions of dollars of European debts, at a time when Europeans themselves were running away from junk debts. They are also one of the largest buyers of US government debt. No African country could play the role China is playing in Africa, the combine foreign reserve of China was more than the GDP of African economies put together. As a matter of fact, no one expects Africa to play any such role; in fact, economic crises in other regions of the world have affected the amount of trade, investments and aid money coming to the continent. Thus, here in Africa analysts were more concerned with ways and manners economic crises and developed nations' trade policies affected Africa's export commodities, as well as aid and development money coming to the continent. But one important sector in Africa the European governments recent economic and trade decisions hit the most was emigration sector. Africans now found it difficult to migrate to Europe even when they possess the needed education and talent. As far as Europe was concerned, investors capital and high net worth individuals were given the necessary welcomed, less endowed individuals and migrants without capital were no longer welcome. This is not to talk of illegal African migrants maltreated and given all kind of inhuman treatments. The number of African migrants that died in the Mediterranean seas has increased in the past five years. As for the millions of Euros remittance money coming to Africa from African migrants working in Europe, Africa should depend less on them and diversified.

North and West Africa are the regions of Africa most connected in trade with Europe, therefore, more vulnerable to contagion coming from Europe. Countries in these regions faced prospects of declining revenue and negative balance of payment position. Any weakening in the value of Euro would affected these countries foreign reserves dominated in Euro. But one positive way foreign crisis affected Africa is by making its people and government to look inward rather than setting eyes on China, Europe and US. Nigerian authorities fought day and night to attract foreign investors with capital and skill to develop the local economy. Countries such as Ghana, Angola, Ethiopia, and Rwanda have been highlighted as African success stories, implementing hard economic prescriptions. The developed countries in the West have always played double standard when it comes to trade. In one hand they would tell the world they are for free trade, but in the other hand they scuttled free trade through imposition of hefty tariffs, subsidies to domestic producers, and other discriminatory policies that favoured local producers over foreign companies. The same double standard is also applied in international climate negotiation, as I explained in the section on climate change and environment. Donald Trump, since coming to power as US president in January 2017, has deployed all kind of dirty trade tactics to harm US trading partners so that domestic US producers would have advantages over firms from those countries he targeted. His 'let makes America great again' slogan and the policy that 
is linked with it has already put America in clashed with EU, China, Canada, Turkey, Mexico, Brazil, Russia, Japan, South Korea, to mention just the prominent ones. While in one hand, the developed economies of Western Europe promised aids to poor African countries, on the other hand they imposed tariffs on agricultural export from Africa in the name of protecting local farmers.

While global powers have not diverted from exploration of space with the view to find new colonies and economic resources, attention seemed to be moving to Africa. This should not come as a surprise to keen observers of happenings around the world. The developed countries of Europe and North America, need markets to absorb their industrial and agricultural outputs. Though, most of what they produced were high end products and services for consumption of rich and wealthy, that notwithstanding they need raw materials to produce these things. They need to stop China from dominating the world economy. Economic power has been moving East for decades now. One of the ways they could do this is by competing in the markets where future growth is expected. These markets are Africa, Middle East, Eastern Europe, Central Asia and Latin America; just like Europe depended on Africa and other developing parts of the world in the past for markets and raw materials. On his last foreign visit to Africa, the former US secretary of state Rex Tillerson advised African countries on how to do business with China; he warned that China debt diplomacy was harmful to Africa. US view of China in Africa has centred on seeing China as imperialist in Africa with one goal of satisfying Chinese demand for raw materials and need for markets for its outputs. Former secretary of state Hillary Clinton had also warned African countries against given out lands to China who would grow foods needed for her domestic market back in China. US interest in Africa included security, energy and mineral resources. France had never hide her renew interest in her former colonies spread around the continent. In fact, France more than any former colonial master has demonstrated attachment to Africa that seemed like colonialism was not yet over. France still play divide and rule tactics, challenging efforts at unity and formation of strong economic blocs that would challenge her interests in the continent. Thus, from the colonial era currency in West Africa being used by Francophone countries to the renew security ties with Sahel countries, France would not let go of Africa. China, an emerging global power house, had showed unflinching link to African resources more than any country in the past two decades.

\section{Economic blocs}

On the 7th of March 2014, Nigeria announced it newly re-base GDP figure last revised in 1990. About two months earlier in January of 2014, Jim O'Neil, a British economist and former employee of the investment Bank Goldman Sachs came out with the acronym MINT (Mexico, Indonesia, Nigeria, and Turkey) more than a decade after he coined the popular acronym BRIC (Brazil, Russia, India, and China). A little later, came PINE (Philippines, Indonesia, Nigeria and Ethiopia) another acronym that added Philippines and Ethiopia as possible important players in the global economy or the region of the world they were located. Since the time Nigerian 
economy became the biggest in Africa, the important of Nigeria inside MINT and similar groups have increased. Nigeria's post-independence journey has been thorny full of ups and downs and sometimes threats of breaking up into pieces. During the tenure of President Obasanjo (19992007) an alleged American think-tank forecast saw Nigeria breaking up in 2015, other forecasts saw Nigeria entering the league of 20 biggest economies in the world, 3rd most populous country in the world, and so on. But, MINT and PINE acronyms were among the positive predictions on Nigeria that predicted Nigeria as playing a positive role in the global economy in the near future.

The last re-basing of Nigeria's GDP has shown to the world some potentialities of Nigeria economy different from the picture outside world had been relaying on in the past, showing Nigeria as a slow growing economy and extremely comatose. Though, the re-basing has changed nothing on the ground, neither the poverty level nor the absence of electric power has improved. But, the fact that it had provided a new reality, a new way of looking at things, from the point of both the authority in Abuja to that of the business world, is a welcome development. Nigerians would be assured that their governments had not been doing enough to improve their lot, looking at the size of the GDP and the enormous potentials on the ground. Already a trend has become clear to most Nigerians that shows consistency in government in ability to put the economy in the right direction. The main question to ask is what next after the re-basing of 2014? Just two years after the re-basing Nigeria found herself in a recession in 2016. Should Nigerians go to sleep knowing that their nation is the biggest economy on the continent? The answer is absolute no, if anything the released GDP figure was a call to duty for the authorities to rise up to the expectation and did the needful to take the country to where it truly belongs. Instead of talking and making noise about potentials which has been the norm since after Independence, Nigeria should pay more emphasis on seeing that It realized those God given potentials. With a big population of over 190 million people Nigeria should have utilized the opportunity to modernize its retail sector. Just like with most other sectors of the economy, the Nigerian retail sector has remained the way it was in the past 30 years with little changes. Government should have encouraged rapid modernization of the sector embark on by foreign and domestic retailers. With population of over 15 million people, Kano and Lagos are the places to be for any retailer who wants to get across to Nigeria growing population of middle class. When you compared Nigeria with members of these groups (MINT, PINE, even D8) you would find Nigeria has a lot of ground to cover. Take for example Mexico, it has been a manufacturing hub that exports automobiles, and electronics, to countries such as United States; Turkey Exported the same category of things to the European Union, the same thing could not be said of Nigeria. Even Indonesia could not be compared to Nigeria in term of manufacturing. In fact, made in Indonesia products were all over the Nigerian markets in the past decade.

An argument was started in 2014 on the then newly released GDP figure with Nigerians questioning the accuracy of the figure given as the new GDP number. Nigerians also at first doubted the position of Nigeria as biggest economy on the continent ahead of South Africa. But, the fact that IMF and World Bank were involved in the re-basing program gave it some authenticity. But, the reality of poverty was not in doubt, world Bank had by then released its 
study on global poverty where Nigeria was ranked third. But, this did not in any way contradicted the earlier released GDP figure, just like it was in the case of China and India. China was the 2nd largest economy in the world ahead of Japan, Germany, France and UK; but, at the same time it was grouped alongside Nigeria and India among the countries with largest concentration of poor in the world in 2014. A Nigerian government official disputed the world Bank study, arguing that Nigeria was not as poor as the World Bank put it. But, that particular government official was hidden the true or he is not going around Nigeria to see things for himself; it was most likely that he lived most of his live in Abuja's luxury where life was like in other big world cities. He had forgotten that in 2014 in Kano city people spent a week without seeing electric light. Nigerians in rural areas had adjusted to the live of penury and hardship, losing any hope that government would remember them one day. I had hope then that those disputing the World Bank study that ranked Nigeria number three made a rethink and traveled to their villages back home, so as to share time with their people and felt how it was like to live there.

Another economic bloc that Nigeria belong to is D8. Developing countries group of eight, more popularly known as D8, is a group that comprises the countries of Nigeria, Turkey, Pakistan, Indonesia, Bangladesh, Iran, Egypt, and Malaysia. The bloc came into being on June 15, 1997 in Istanbul Turkey, the idea came from the then president of Turkey Dr. Necmettin Erbakan, in what is today commonly refers to as the 'Istanbul declaration'. The objective of D-8 organisation for economic cooperation are to improve member state's position in the global economy, diversify and create new opportunities in trade relations, enhance participation in decision-making at international level, and improve standards of living'. With a combine population of about 1 Billion people which is about $13 \%$ of the total world population and combine global trade figure of over \$1.8 Trillion at the end of 2012 which is about 5\% of the total global trade that year, the bloc is set to become one of the most important trading bloc in the world that cut across more than one region. Unlike trading unions such as European Union, ECOWAS, NAFTA, or COMESA, D-8 cut across regions of the world from Africa to Middle East, South Asia, to South East Asia. The bloc set a target of $\$ 500$ billion of trade between member countries from the 2012 figure of around $\$ 160$ billion. The much talk about MINTs economies that comprised Mexico, Indonesia, Nigeria, and Turkey included three members of D-8 out of the four countries that made up the group. In the acronym PINEs that include Philippines, Indonesia, Nigeria, and Ethiopia, two out of the four members of the group are from D- 8 group. This further drive home the potential of the D- 8 as the future mover of the economies of the regions of Asia and Africa. The fact that they are part of the high potential emerging economies, with stable regimes in about $90 \%$ of them and prevailing peaceful atmosphere in about $80 \%$ of them, make it likely for them to help shape the global economy in the near future. That is why it is pertinent for Nigerian authorities to develop a strategy of utilizing the opportunity. It is not enough for Nigeria to be member of only regional economic blocs like ECOWAS or AU, D-8 membership span four regions of the world with different geography and economic potentials.

Benefits for Nigeria in D-8 are enormous. The countries in the group have things in common, starting with population which determine sizes of their domestic markets. The fact that their 
populations composed of young people made their future potentials bright. They were fast growing economies as seen from their GDP growth rate. Some of them have superb infrastructures such as Turkey, Malaysia, and to some extent Indonesia and Iran. Two of them are members of G-20, Turkey and Indonesia. Two of them have neared point of inclusion in the so-called newly industrialized countries, Turkey and Malaysia. Five of them are energy producers, Iran, Nigeria, Malaysia, Indonesia, and Egypt. Seven of them are transport corridors and strategic connection points to other regions, Turkey, Egypt, Pakistan, Iran, Malaysia, Indonesia and Nigeria. Turkey joints Europe and Asia by means of Istanbul and, Black and Mediterranean seas through seas of Marmara. Egypt joints Europe and Asia through Suez Canal, as well as Africa and Asia through Sinai Peninsula. Pakistan is strategic link that connects Central Asia to Indian Ocean and serves as point of connection between the two giants of Asia (China and India) in one hand and Middle East region on the other. Iran connects Central Asia and the oil rich Gulf region. Malaysia and Indonesia stand at the world strategic strait of Malacca, as well as being the connection between Asia and Australia. Nigeria is regional hub in Africa that connects West Africa to Central Africa and Lake Chad region to the sea. Three are top tourist destinations Turkey, Malaysia, and Egypt. Two have world class education system that attract all sorts of students from around the world, Turkey and Malaysia. Two have a growing civil aviation industries that have the capability to produce commercial airplanes, Indonesia and Turkey. In term of manufacturing Turkey is far advanced than any other D-8-member country, with an industry that produces electronics (for example, two of Turkish manufacturers -Vestel and BEKO are major TV producers in Europe supply Western Europe with domestic electronics). Turkey has well-grounded automobile manufacturing industry that supply neighboring regions with cars and their spare parts.

Nigerian investors such as Dangote can seize the group emphasis on private sector activities to exploit investment opportunities in the bloc. Turkish and Pakistan investors have seized the moment by investing in Nigeria in sectors such as education, health, defense, textile, agriculture and transportation. Nigeria should place more emphasis on agriculture where Nigeria would learn from Turkey, Indonesia, Pakistan and Malaysia. Mechanization and large scale use of fertilizer have reached advanced stage. Fertilizer production and trade among member countries was on the agenda of the group as meetings had been hosted on its. Dangote forayed into the making of fertilizer with his investments of billions of Dollars would marched well with D-8 emphasis on the agriculture. Nigerian banking industry could make use of the opportunity to open shops in locations where Nigerians frequent such as Istanbul, Cairo, and Kuala Lumpur. In term of development of financial industry, Nigeria has much to benefit from closer tie with Malaysia and Turkey particularly in the area of Islamic banking and financing. In terms of military and security alliances, Nigeria has started to cooperate with Pakistan on ways to share ideas and resources on security threats. Pakistan has longer experience in dealing with Taliban insurgence than Nigeria has with Boko Haram, though they were all very violent and deadly. But, as Nigerian military authorities have found out, Nigeria has much to learn from Pakistan in term of strategy to counter the insurgency. Pakistan is a nuclear power with a rapidly growing weapons production industry that boast of local productions of military tanks, war planes and drones. 
Nigeria should use this opportunity to revive it comatose defense industry base in Kaduna. This would reduce Nigeria usage of foreign exchange to procure military equipment which would henceforth be locally produced. This is a vast area, Nigerian defense budget at the height of Boko Haram crisis run into trillion Naira. By reducing the use of foreign exchange to buy weapons from abroad, more money would be freed for better used by other sectors of the economy such as education and health. Already, Turkey and Pakistan are looking at a proposal of setting up military and textile industries in Nigeria. But, this should not stop there, it should be extended to other areas such as Pharmaceuticals, agriculture, and energy supply.

\section{$\underline{\text { Trade politics }}$}

The Daily Trust business story of Monday, March 24, 2014 captioned "Dangote draws Nigeria, France into 'cement war' in Senegal" was quick in firing my imagination about possible links between events occurring around that period. Thus, this subsection is continuation of the previous section on Nigeria economic interests abroad, particularly within the emerging markets of Africa and Asia. In the past, there were hypotheses linking foreign powers with support of insurgency in Nigeria's North East. The Daily Trust story said that the then French President Francois Holland had written his Senegalese counterpart Macky Sall in January of the year for him to intervene on Behalf of a French cement company SOCOCIM which had about 65\% share of the local cement market in the West African country of Senegal. This was on the back of the reality that Dangote's new cement plant in Senegal did not even started production as at the time; though, the lead story said that it would start operations in the next 90 days with annual output of three million tons of cement about three-fifths of which would be sold inside Senegal. The building of the new plant cost Dangote some $\$ 630$ million and was reputed to be one of the largest cement plants on the continent. Looking at map of Dangote cement plants distribution across Africa, Dangote was fast growing his cement empire across this part of the world. But, a particular French company (Lafarge) was the biggest cement producer in the world. Hence, there was connection between the ambition of Dangote to make his company the largest producer of cement in the world and the French domination of global cement market. Dangote cement had operations in 15 African countries where French cement companies have already made footprints over the years; after French granted independence to its African colonies. The fact that Dangote cement has dominated Nigerian market, Africa biggest economy, made Dangote cement a threat to France's cement tycoons. The importance of cement production as a most visible sign of growth in any country's economy could not be skipped. As consumption of cement in a region or nation increased so is its GDP.

European imperialism should have died with the ending of colonialism in Africa, but not so fast say the French people. France has continued to stick it nose in African affairs, refusing to read the bold writing on the wall that era of colonialism is over. But, Africa has been freed for so many years now and Africans have the right to determine their fate without interference from an old colonial power. France had more colonies in Africa than other European nations, but unlike 
Britain which was a sea power (mainly colonizing countries with access to the sea) France had a lot of its colonies in the hinterland. The old colonial policy of assimilation championed by France have been used in a modern form to protect interest of France on the continent. Hence, the desperation to use any means possible to sustain France interests, including propping up of dictators as seen in Algeria (Bouteflika), Chad (Idriss Debi), Cameroon (Paul Biya), Zaire (Mobutu Sese Seko), and her alleged role in Rwandan genocide of 1994. France had also been accused of supporting rebels who threaten to secede from countries opposed to France interest on the continent, as was the alleged case with France support for the short-live Biafra Republic from Nigeria in the 1960s. Hence, the reason why France is keenly watching Chinese activities in Africa. But, Dangote was not the only Nigerian businessman threatening his France competitors on the continent, other Nigerians business moguls with wider interest on the continent should have been more cautious and alert. Businessmen such as Tony Elumelu of Heirs holdings with controlling shareholding in UBA (with Branches in Many African countries), Mike Adenuga who control Glo telecommunication company and many ambitious Nigerian businessmen with plan to diversify into the continent have South Africa, US, France, China and Indian interests in Africa to contend with. French companies, according to Melly and Darracq (2013), "are particularly strong in sectors such as logistics, port and rail operations, telecoms, shipping, banking and air transport; they also have significant interests in tropical commodities and agriculture". France interests in West Africa is strategic and important than in other part of Africa because of economic interests there. Hence, the France's keen interest on major players in the region; particularly Nigeria the largest economy on the continent. The fact that in term of population Nigeria alone made up half of the entire population of the 16-member ECOWAS community and likewise in total GDP of the sub region, France attention would always be on Nigeria because of these.

It was no coincidence that despite Nigerian contributions to peace keeping in Mali, leadership of African Union ( $A U$ ) intervention forces that restored peace to the country was quickly taken away from Nigeria and given to a former French colony. Nigerians knew of antagonism of big Western countries to Nigerian leadership of ECOWAS, especially her achievements in restoring peace in Liberia and Sierra Leone. Hence, the rush in reducing her influence in Mali which unlike Liberia and Sierra Leone was colonized by France during the hectic days of imperialism. Economic interest has always been in the front burner in France incursion into Africa. Faten Aggard-Clerx observes that "Over the last 10 years, France's share of African trade plummeted from 10 percent to 4.7 percent [Fr]. France is not the only country that lost ground. In fact, the Western countries' share of African trade and investment has declined as a result of the increased engagements of emerging countries notably Malaysia and China. Hollande seems resolved to regain such space and put a bold commitment forward to double trade with Africa in the next five years" Niger republic, Nigeria northern neighbor, remained the main supplier of uranium to France. Recently, there were demonstrations across Niger calling for stop to the exploitative and damaging term of trade based on which France companies exported uranium out of Niger to France. France energy production was heavily skewed in favour of nuclear energy with more than $30 \%$ of her 
energy needs supplied by nuclear power plants spread around the country. France has recently rediscovered her reliance on its former colonies and the need to further widen its economic interests there. Analysts such as Mehdi Taje of the strategic security center for the Sahel and Sahara was of the opinion that France is determined to "secure the energy resources of the Sahel and deter rival powers such as China, Russia, India and, to a lesser extent, Brazil. For the French, the time of the conquest of territories had been completed," ... "France wants to strengthen its presence gently, but still strong enough to scare the Chinese". On this French interest on Africa, Melly and Darracq (2013) had this to say, "French policy matters in Africa in a way that elsewhere outside Europe it does not". It is, therefore, out of focus for any Nigerian businessman who want to expand out of Nigeria into other African countries to make mistake of not putting France and her Africa interests in his radar. The UK's perpetuated movement out of the European Union has made the former colonial power to set her eyes on her former colonies in Africa; thus adding to the number of foreign powers with interest on the continent. 


\section{Bibliography}

Abdullah, F., Hassan, T., Mohamad, S. (2007), "Investigation of performance of Malaysian Islamic unit trust funds: Comparison with conventional unit trust funds", Managerial Finance Vol. 33 No.2, 2007 pp 142-153

Abdullahi, S. I. (2006), "The World Bank programs in poor countries: Matters Arising” www.worldbank.org/sup

Abdullahi, S. I. (2011), "Walking on a string: Bank management in a world upside down", Available at SSRN: $\underline{\text { http://ssrn.com/abstract }}$

Abdullahi, S.I. (2013), "Islamic banking in West African Sub region: a survey", Arabian Journal of Business and Management Review (OMAN Chapter) Vol. 2, No.7, pp.

Abdullahi, S.I. (2017) 'Islamic advertising in Nigeria: an assessment', Int. J. Islamic Marketing and Branding, Vol. 2, No. 1, pp.65-84.

Abdullahi, S.I. (2018) 'Measuring consumer perception of ethical issues in advertising: evidence from Nigerian advertising audience', Middle East J. Management, Vol. 5, No. 3, pp.191-206.

Abdullahi, S. I. (2018), "Risk management and corporate governance: An Islamic perspective”, in Toseef Azid, Ali A Al Nodl and Muhammad Azeem Qureshi (eds), 'Research in Corporate and Shariah Governance in the Muslim World' London, Emerald publishing company

Adamu, A. U. and Ado-Kurawa, I. (2010), eds. "Perspectives on Kano" Vol. 1, Inuwar Jama'ar Kano (Kano forum)

Adebayo, R. I. (2010), "The motivating factors for the viability of Islamic Banking in Nigeria", 
The international association of Islamic Bank Karachi, Vol. 27 NO.2

Adeola, H. (2009), "Islamic Finance: the answer to financial inclusion in Nigeria”,

A presentation at EFInA Conference July 2009

Ado-Kurawa, I. (2006), "Investment opportunities in Kano: the centre of commerce",

Research and documentation directorate, Kano state government

African economic outlook, 2012: promoting youth employment

Agenor, P. R. and J. Aizenman (2003), "Savings and the Terms of Trade under

Borrowing Constraint", Journal of International Economics 63.

Aggad-Clerx, F., "France: Out of Africa and Back?", available at, www.aljazeera.com/.../france-out-africa-back-20131214112634946877

Agil, S. O. (2005), "Readings in the concept and methodology of Islamic Economics", Kuala Lumpur, CERT Publications

Aliyu, C. U. (2005), "The experience of Usman Danfodio University in Muslim Educational Reform", in Baffa Aliyu U. and et al edited "Muslim educational reforms activities in Nigeria", Kano, Benchmark publishers, pp 143- 150

Al-Omar, F. and Abdel-Haq, M. (1996), "Islamic banking: theory, practice and challenges", London, Zed Books

Aluko S.A. (2008), "corruption and national development", A lecture delivered at the centre for democratic development research and training, Zaria Kaduna state, on Saturday 31st May, 2008.

Amin, S. (2000), "Capitalism in the age of globalisation”, London, Zed Books

Boahen, A. A. (1976), "Topics in West African history", London, Longman group limited

Braguinsky, S., Klepper, S., Ohyama, A. (2009) "Schumpeterian Entrepreneurship", National Science Foundation, USA.

Bresler, I. "Mali: why France is fighting for West Africa", available at, www.theforeignreport.com/.../mali-why-france-is-fighting-for-west-afric.

Businessday Nigeria, "Would informal retailers remain relevant in Nigeria?" Wednesday 11 
April, 2012

Caves, R. E. and Jones, R. W. (1977), “World trade and payments”, Boston, Little Brown and Company

Chatham House, Africa 2013/01, available at, www.chathamhouse.org/sites/default/.../Africa/0513pp_franceafrica.pdf

Chimobi, O. P. (2010), "Inflation and Economic Growth in Nigeria", Journal of Sustainable Development Vol. 3, No. 2; June 2010

Collins, J. and Porras, J. I. (2002), "Built to last", New York, Collins

Collins, J. (2001), "Good to great", London, Random House

Corden, M. (1991), "Macroeconomic policy and growth: Some lessons of experience", in "the proceeding of the World Bank annual conference on development economics 1990" pp74

Davig, T. and Hakkio, C. (2010), "What is the effect of financial stress on economic activity?", Federal Reserve Bank of Kansas City Economic Review, Vol. 95, No.2 pp 37

Dimitrova, D. (2005), "The Relationship between Exchange Rates and Stock Prices: Studied in a Multivariate Model", Issues in Political Economy, Vol. 14

Doguwa, S. I. (2013), "Inflation and Economic Growth in Nigeria: Detecting the Threshold Level", CBN Journal of Applied Statistics Vol.3 No.2

Euro Monitor International, 'Retailing in Nigeria', Country Report, 2012

Evbuomwan, G. O., Okoruwa, V. O., and Ikpi, A. E. (2013), "Effect of Deposit Money Banks' Credit on the Performance of Micro, Small and Medium Enterprises in Nigeria", Central Bank of Nigeria Economic and Financial Review, Volume 51, Number 2, p. 63-92

Galbraith, J. K. (1963), "The affluent society", Toronto, Mentor Book Gelbard, E., Hussain, M., Maino, R., Mu, Y., and Yehoue, E.B. (2014), "Islamic Finance in SubSaharan Africa: Status and Prospects", IMF Working Paper WP/14/149 Global Islamic Finance Report (GIFR 2010) Post Conference Report International Islamic banking 
summit Africa, Djibouti 2016

Golit, P. D. and Adesanya, O. (2013), “Does Gender Inequality Retard Productivity in

Nigeria? A Search for Evidence", Central Bank of Nigeria Economic and Financial Review Volume 51, Number 3, p.41-56

Hagedoorn, J. (1996), “Innovation and Entrepreneurship: Schumpeter Revisited”, Industrial and corporate change journal, Vol. 5 No. 3, Oxford university press

Hallward, J. (2005), “Understanding Brand Value: A review of price, performance, equity, and category Dynamics", Ipsos-ASI, Advertising Research Company

Hassan, M. and Dridi, J. (2010), "The effects of the global crisis on Islamic and conventional Banks: A Comparative study", IMF working papers, WP/10/201

Honig, B. (2004) “Entrepreneurship Education: Towards a Model of Contingency Based Planning" Academy of Management Learning and Education U.K Idih, J. F. and Olu, E. O. (2015), "Inflation and economic growth in Nigeria", Journal of Economics and International Business Management Vol. 3(1), pp. 20-30 Iganiga, B. (2010), "Evaluation of Nigerian Financial sector reforms using behavioral models", in Journal of Economics, Vol. 1, No. 2 pp 65-75

Johnson, G. and Scholes, K. (1997), "Exploring corporate strategy", London, Prentice Hall Kahf, M. (2002), "Strategic Trends in the Islamic Banking and Finance Movement", A paper presented at the Harvard Forum on Islamic Finance and banking, Harvard University, Cambridge, Boston, April 6-7 2002

Kano state economic empowerment and development strategy (K-SEED), September 2004 Kiyosaki, R. and Lechter, S. L. (1998), "Rich dad Poor dad”, New York, Warner Books Kiyosaki, R. and Lechter, S. L. (2002), "Retire Young, retire rich”, New York, Warner Books Kotler, P. (2006), “Marketing management”, Prentice Hall Lawal G. (2007), “Corruption and development in Africa: challenges for political and economic change", Humanities and social sciences Journal 2(1), Lindholm, R. W. and Driscoll, P. (1967), "Our American Economy", New York, Harcourt, Brace 
and World Inc.

MacEwan, A., (1999), “Neo-Liberalism or Democracy? Economic strategy, markets, and alternatives for the $21^{\text {st }}$ century", London, Zed Books

Mbutor, O. M., Ochu, R. E. and Okafor, I. I. (2013), "The Contribution of Finance to Agricultural Production in Nigeria", Central Bank of Nigeria Economic and Financial Review Volume 51, Number 2, p. 1-20

Melly, P. and Darracq, V., "A new way to Engage? French policy in Africa from Sarkozy to Hollande", Chatham House, Africa 2013/01, available at, www.chathamhouse.org/sites/default/.../Africa/0513pp_franceafrica.pdf

Mintzberg, H., Quinn, J. B., and Ghoshal, S. (1998), "The strategy process", Revised European Edition, London, Prentice Hall

Mishkin, F. S. (2013), "The economics of money, banking, and financial markets", Boston, Pearson

Nguyen, A.D., Dridi, J., Unsal, F. D. and Williams, O. H. (2015), "On the Drivers of Inflation in Sub-Saharan Africa", IMF Working Papers WP/15/189

Nwoye, M. (2007), “Gender Responsive Entrepreneurial Economy of Nigeria: Enabling Women in a Disabling Environment", Journal of International Women's Studies, vol. 9 no. 1 , p.166-175

Olutayo, O. A. (199), "the Igbo entrepreneur in the political economy of Nigeria", African Study Monographs, 20(3): 147-174,

Osaze, E. B., (2007), “Capital Market: African \& Global”, The Book House Company, Lagos Oyovbaire, S.E. (2007), "the crisis of governance in Nigeria", convocation lecture, University of Port Harcourt, Thursday 15th March, 2007

Peters, T. (1997), "The circle of innovation”, Coronet Books

Sanusi, S.L. (2011), "Islamic finance in Nigeria: issues and challenges", Lecture delivered at Markfield institute of higher education, Leicester, UK

Senor, D. and Singer, S. (2011), "Start-Up nation", New York, Twelve Books 
Shafique, A, Faheem, M. A. and Abdullah, I. (2012), " Impact of global financial crisis on the Islamic banking system", Arabian Journal of Business and Management Review (OMAN Chapter) Vol. 1, No.9; April 2012

Sirower, M. L. (1997), "The synergy trap", New York, The Free Press

Smutniak, J. (2004), "A survey of Risk", The Economist, January 24 ${ }^{\text {th }}, 2004$

The Economist, 'International banking', May 14 ${ }^{\text {th }}, 2011$

The Economist, 'The News Industry', July 9th 2011,

The Economist, 3rd December, 2011

The Economist, December 11th 2012

The Economist, Sep 7th 2013

Tijjani, B. (2000), "Share valuation and stock market analysis in emerging markets: the case of Nigeria", Kano, Adamu Joji publishers

Tobin, J. and Golub, S. (1998), "Money, Credit and Capital”, Mc Graw-Hill

Tvedten, K., Hansen, M. W. and, Jeppesen, S. (2014), “Understanding the rise of African business: In search of business perspectives on African enterprise development", African Journal of Economic and Management Studies, Vol. 5 No. 3, pp. 249-268

Uzonwanne, J. (2011), "Investing in Nigeria: A brief Strategy Guide", Monitor company Group

Valencia, M. (2010), "Financial risk", a special report, The Economist, February $13^{\text {th }}, 2010$

Wansell, G. (1987), "Tycoon: the life of James Goldsmith", London, Grafton Books

Wasiuzzaman, S., Gunasegavan, U. N. (2013) "Comparative study of the performance of Islamic and conventional banks: The case of Malaysia", Humanomics, Vol. 29 Iss: 1, pp.43 - 60

WIN-Gallup International Global Index of Religiosity and Atheism (2012) [online] http://www.Gallup-international.com (accessed 6 October 2016). World Bank "The East Asian Miracle: Economic Growth and Public policy", Oxford University 
Press 1993

World Bank, "Bureaucrats in Business: the economics and politics of government ownership", Oxford University Press, 1995 